MARCELO VILELA DE ALMEIDA

\title{
MATRIZ DE AVALIAÇÃO DO POTENCIAL TURÍSTICO DE LOCALIDADES RECEPTORAS
}

Tese apresentada ao Programa de Pós-Graduação em Ciências da Comunicação (Área de Concentração: Relações Públicas, Propaganda e Turismo - Linha de Pesquisa: Turismo \& Lazer) da Escola de Comunicações e Artes da Universidade de São Paulo, como exigência parcial para a obtenção do título de Doutor.

Orientador: Prof. Dr. Mário Carlos Beni

São Paulo 


\section{MATRIZ DE AVALIAÇÃO DO POTENCIAL TURÍSTICO DE LOCALIDADES RECEPTORAS}

Marcelo Vilela de Almeida

COMISSÃO EXAMINADORA

Presidente: Prof. Dr. Mário Carlos Beni 
Ao pequeno Lucas, cuja chegada foi tão aguardada $e$ bem-vinda durante a conclusão deste trabalho. Em nome dele eu dedico isto tudo, também, a toda a minha família. 
O meu mais profundo agradecimento a muitas (tantas!) pessoas:

Ao meu orientador, Prof. Dr. Mário Carlos Beni, que mais uma vez me acolheu nesta Instituição, o meu agradecimento muito especial pela confiança e por todo o apoio ao longo de mais esta jornada;

às professoras componentes da banca do exame de qualificação,

Prof ${ }^{a}$. Drª. Dóris van de Meene Ruschmann e Prof ${ }^{a}$. Dra Madalena Pedroso

Aulicino, pela indicação dos caminhos a seguir;

aos amigos do Serviço Brasileiro de Apoio às Micro e Pequenas Empresas (SEBRAE-SP) - Escritório Regional de Guaratinguetá/SP, Marco Aurélio Rosas, do Centro Universitário Salesiano de São Paulo - Unidade de Lorena,

Prof ${ }^{a}$. Fátima Medeiros, Prof. Júlio César Moreno e à acadêmica Adriana Oliveira, e do Instituto de Estudos Valeparaibanos, Prof. José Luiz Pasin, pelo fornecimento de material sobre os municípios estudados e pela troca de idéias

à minha família, em especial à minha esposa, Rita de Cássia Gonçalves Prado, por todo o apoio, desde sempre e nos momentos mais difíceis;

à amiga Ana Paula Garcia Spolon, pelo auxílio quanto aos textos em inglês e pela revisão lingüística e metodológica;

à amiga Isabel Cristina Nogueira, pela obtenção do material bibliográfico junto ao Ministério da Indústria, Comércio e Turismo da Espanha;

aos amigos do Centro Universitário Senac, por todo o apoio e, em especial a Flávia Maria Santana de Assis e Hélio César Hintze, pelo auxílio no uso dos recursos de informática;

ao amigo Prof. Dr. Alexandre Panosso Netto, pelas orientações na fase de qualificação;

e a todos os demais amigos, cujos nomes prefiro omitir dada a quantidade e o risco de cometer mais injustiças ao esquecer de alguém, pela força e paciência nos momentos de ausência;

à Geslayne Franz Ferreira, pela importante ajuda na interlocução com meu orientador;

aos funcionários do Serviço de Pós-Graduação e do Departamento Relações Públicas, Propaganda e Turismo da Escola de Comunicações e Artes da Universidade de São Paulo (ECA/USP), pelo apoio acadêmico. 
"E aprendi que se depende sempre De tanta, muita, diferente gente Toda pessoa sempre é as marcas Das lições diárias de outras tantas pessoas". (GONZAGUINHA, Caminhos do coração) 


\section{RESUMO}

ALMEIDA, Marcelo Vilela de. Matriz de Avaliação do Potencial Turístico de Localidades Receptoras. Tese (Doutorado) - Escola de Comunicações e Artes, Universidade de São Paulo, 2006. 233 p.

A presente tese tem por objetivo principal identificar as possibilidades de uma factível e confiável avaliação do potencial turístico de localidades receptoras e como objetivos secundários/específicos analisar a abordagem do objeto de estudo nas bibliografias nacional e internacional específicas e propor a formulação e a utilização de um instrumento de avaliação do potencial turístico de localidades receptoras, a fim de minimizar o caráter subjetivo predominante neste tipo de análise. Os procedimentos adotados para a verificação das hipóteses formuladas foram: pesquisa bibliográfica exploratória sobre o tema, com levantamento da bibliografia pertinente para a constituição do referencial teórico; definição dos municípios-objetos de estudo (Guaratinguetá e Cunha/SP, localizados no eixo principal do Roteiro Integrado Estrada Real - representante da Região Sudeste no Projeto Rede de Cooperação Técnica para a Roteirização, do Programa de Regionalização do Turismo "Roteiros do Brasil"); pesquisa bibliográfica e de campo sobre os municípios-objetos de estudo; formulação do instrumento de avaliação do potencial turístico, a partir da definição das variáveis a serem identificadas e de sua operacionalização; desenvolvimento e aplicação do instrumento de avaliação do potencial turístico proposto nos municípios escolhidos; análise dos dados e cruzamento das informações obtidas com o referencial teórico constituído inicialmente. Chega-se, por fim, a uma comparação entre o potencial turístico de Guaratinguetá e Cunha à luz da definição ora estabelecida e recomenda-se a aplicação do instrumento, com as adaptações e os ajustes necessários, a outras localidades, a fim de possibilitar melhores condições para o planejamento e a gestão da atividade turística nas localidades receptoras e para um direcionamento mais adequado das políticas e dos investimentos públicos na área.

Palavras-chave: potencial turístico, planejamento turístico, avaliação, Guaratinguetá, Cunha. 


\section{ABSTRACT}

ALMEIDA, Marcelo Vilela de. Potential Assessment Matrix of Receptive Touristic Locations. Thesis (Doctorate) - Escola de Comunicações e Artes, Universidade de São Paulo, 2006. 233 p.

This present thesis aims at identifying the possibilities of a enforceable and dependable assessment of touristic potential receptive locations and has as secondary/specific objectives analyzing the approach on the object of the study in specialized national and international bibliographies as well as proposing the formulation and use of an assessment instrument for touristic potential of receptive locations in order to minimize the predominant subjective character in this sort of analysis. The procedures adopted for verification of the formulated hypothesis have been: exploratory bibliographic research on the theme, including investigation of pertinent bibliography for constitution of theoretical referential; definition of citiesobject (Guaratinguetá and Cunha/SP, located in the main axis of Real Road Integrated Route - representatives of the Southern Region in the Project Technical Cooperation Network for Routing, of the Tourism Regionalization Program "Routes of Brazil"); bibliographical and field research in the cities-object of study; formulation of an assessment instrument of touristic potential from a definition of touristic potential variables yet to be identified and of their operationalization; development and application of the assessment instrument of touristic potential proposed in the chosen cities; data analysis and information crossing obtained through theoretical reference initially constituted. It eventually reaches to a comparison between the touristic potential of Guaratinguetá and Cunha in the light of the definition now established and recommends the instrument application - with all necessary adaptations and adjustments - to other locations, in order to provide better conditions for planning and management of touristic activities in the receptive locations and a more adequate implementation of public politics and investments in the area.

Key-words: touristic potential, touristic planning, assessment instrument, Guaratinguetá, Cunha. 


\section{LISTA DE QUADROS}

QuAdro 1 - TiPos de Potencialidades/RealizaÇÃo dos Atrativos NatURAis .......... 18 QUADRO 2 - GRAU DE ATRAÇÃo tURíSTICA DOS MUNICÍPIOS DA REGIÃo METROPOLITANA DA BAIXADA SANTISTA (EM ORDEM DECRESCENTE) .............................................. 44

Quadro 3 - Composição da Matriz de Avaliação do Projeto Pólos de DESENVOLVIMENTO DE ECOTURISMO NO BRASIL ............................................... 49

QUADRO 4 - VALORAÇÃO ECOTURÍSTICA ….................................................... 51

QUADRO 5 - AVALIAÇÃO DA OFERTA DE ALOJAMENTO ............................................. 54

QUADRO 6 - AVALIAÇÃO DA OFERTA DE ALIMENTAÇÃO......................................... 55

QUADRO 7 - AVALIAÇÃO DA OFERTA DE ENTRETENIMENTOS ..................................... 55

QUADRO 8 - AVALIAÇÃO DA OFERTA DE OUTROS SERVIÇOS...................................... 57

QUADRO 9 - AVALIAÇÃO DOS ATRATIVOS TURÍSTICOS ............................................ 58

QUADRO 10 - PONTUAÇÃO PARA AVALIAÇÃO DOS FATORES PARA LOCALIZAÇÃO DE PROJETOS TURÍSTICOS............................................................................. 63

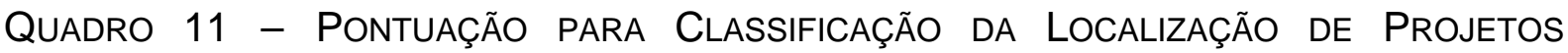

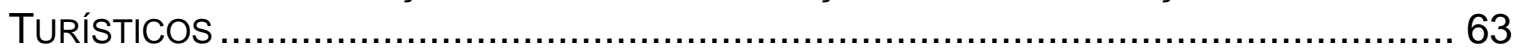

QUADRO 12 - AVALIAÇÃO dOS FATORES PARA LOCALIZAÇÃo DE PROJETOS TURÍSTICOS. 67 QUADRO 13 - HIERARQUIZAÇÃO DA QUALIDADE DOS ATRATIVOS TURÍSTICOS ..................69

QUADRO 14 - HiERARQUIZAÇÃo dA QUALIDADE dOS ATRATIVOS TURíSTICOS ....................69

QUADRO 15 - ESCALAS DE ÍNDICES PARA O TURISMO DE CONTEMPLAÇÃO ....................... 75

QUADRO 16 - ESCALAS DE ÍNDICES PARA O TURISMO DE DESTINAÇÃO ............................ 76

QUADRO 17 - AVALIAÇÃO DO POTENCIAL DAS ÁREAS DE DESENVOLVIMENTO TURÍSTICO DA

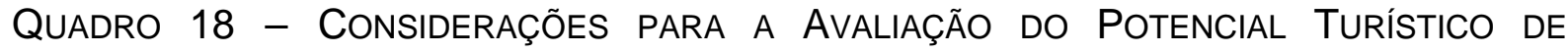

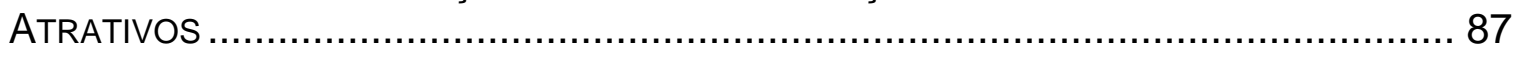

QUADRO 19 - ROTEIROS TURísticos INTEGRAdOS DA REDE DE COOPERAÇÃo TÉCNICA

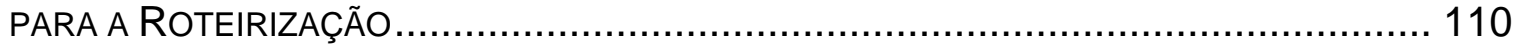

QuAdro 20 - MATriz de AvaliaÇÃo do POtencial Turístico de Localidades

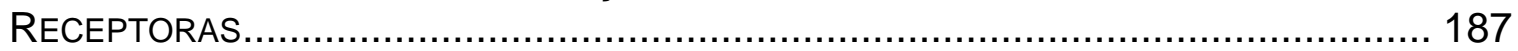

QUADRO 21 - MATRIZ DE AVALIAÇÃO DO POTENCIAL TURÍSTICO DE GUARATINGUETÁ/SP197 QUADRO 22 - MATRIZ DE AVALIAÇÃo do POTENCIAL TURÍSTICO DE CUNHA/SP .............. 204 QUADRO 23 - ANÁLISE COMPARATIVA DO POTENCIAL TURÍSTICO DE GUARATINGUETÁ E CUNHA 211

QUADRO 24 - EVOLUÇÃo dOS NúCLEOS URBANOS do VALE DO PARÁ́BA..................... 233 


\section{SUMÁRIO}

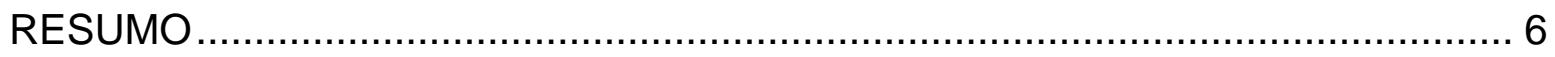

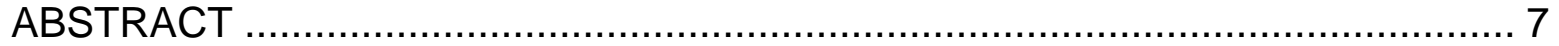

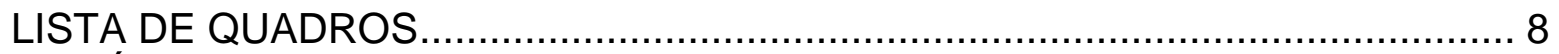

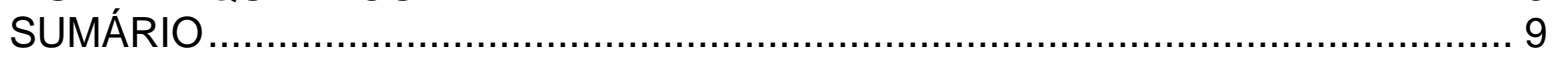

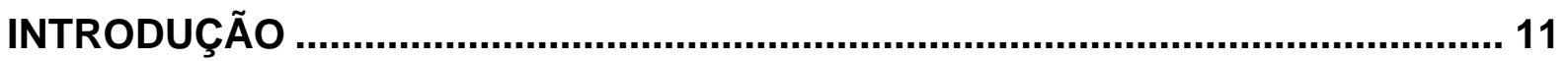

1 REVISÃO TEÓRICO-METODOLÓGICA .......................................................... 34

1.1 O GRaU de ATRAÇÃo TURÍSTICA DE PINZAN .................................................. 41

1.2 A Matriz de Avaliação do Projeto Pólos de Desenvolvimento de

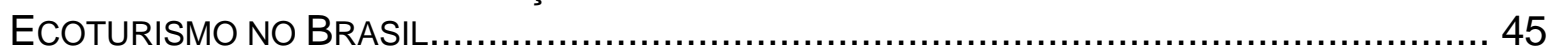

1.3 A CLASSIFICAÇÃO E A AVALIAÇÃO dOS MUNICÍPIOS TURÍSTICOS DE BOULLÓN..........5 52

1.4 O ÍNDICE DE ATRATIVIDADE TURÍSTICA DE GEARING, SWART E VAR ......................59

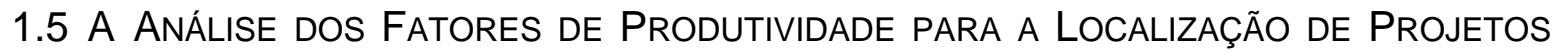

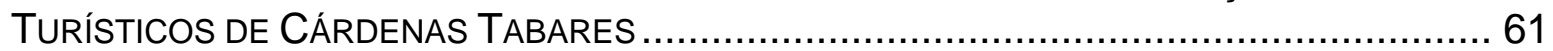

1.6 A MATRIZ DE AVALIAÇÃO dE ATRAÇÕES TURÍSTICAS DE INSKEEP.............................. 70

1.7 A Abordagem da Avaliação Regional do Potencial de Desenvolvimento

TURÍSTICO DE GUNN ..................................................................................... 73

1.8 O ÍNDICE DE POTENCIAL TURÍSTICO DE FERRARIO ............................................ 79

1.9 A AVALIAÇÃo do Potencial dAS ÁREAS dE DESENVOLVIMENTO TURÍSTICO do PLANO NACIONAL DE DESENVOLVIMENTO TURÍSTICO DA TAILÂNDIA ..................................... 82

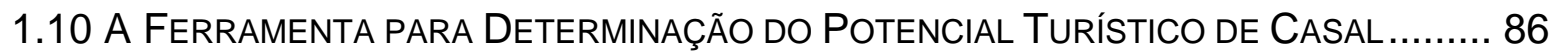

1.11 A AdaPtaÇão da Metodologia de HieraRQuizaÇÃo de ReCuRSOS Turísticos da OEA para Aplicação na COMUnidade Autônoma de La RIOJa pOR AlvareZ

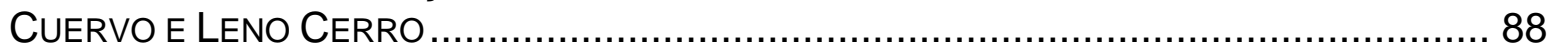

1.12 A AVALIAÇÃO DOS RECURSOS TURÍSTICOS DA OMT ...................................... 92

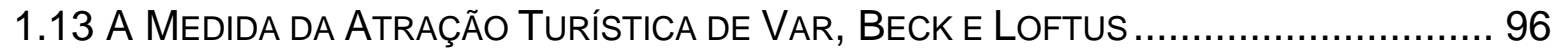

2 CONTEXTUALIZAÇÃO E DELINEAMENTO DOS MUNICÍPIOS-OBJETOS DE

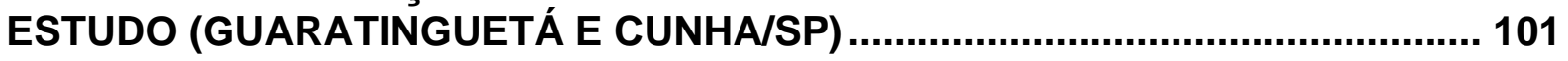

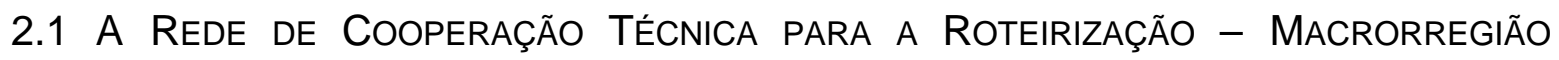
SUdESTE COMO AÇÃO OPERACIONAL DO PROGRAMA DE REGIONALIZAÇÃO dO TURISMO -

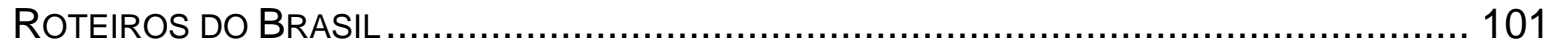

2.2 O ROTEIRO INTEGRADO ESTRADA REAL ................................................ 118

2.3 OS MUNICÍPIOS DE GUARATINGUETÁ E CUNHA/SP: JUSTIFICATIVA DA ESCOLHA DOS MUNICÍPIOS-OBJETOS DE ESTUDO, CONTEXTUALIZAÇÃO REGIONAL E CARACTERIZAÇÃO

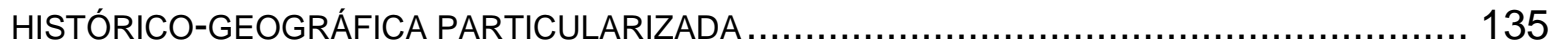

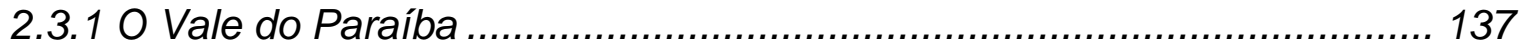

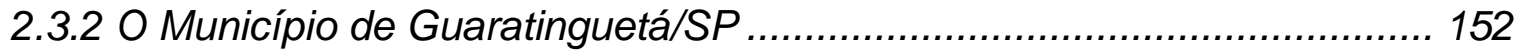

2.3.3 O Município de Cunha/SP ........................................................... 157

3 OS ESTUDOS DE POTENCIALIDADE TURÍSTICA DE GUARATINGUETÁ E CUNHA/SP - PROPOSTA DE MATRIZ DE AVALIAÇÃO DO POTENCIAL TURÍSTICO DE LOCALIDADES RECEPTORAS E SUAA APLICAÇÃO NOS MUNICÍPIOS-OBJETOS DE ESTUDO …...................................................... 160

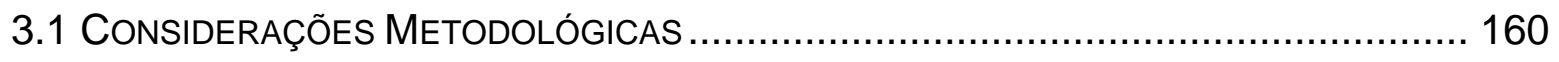


3.2 Aplicação da Matriz de Avaliação do Potencial Turístico de localidades RECEPTORAS AOS MUNICÍPIOS DE GUARATINGUETÁ E CUNHA ................................. 188

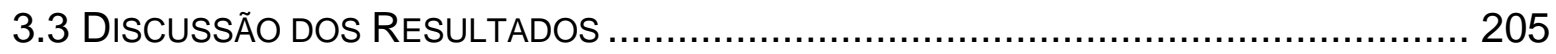

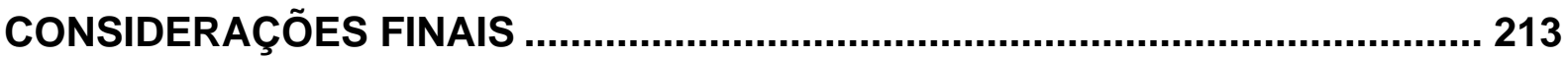

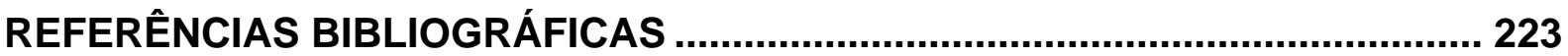

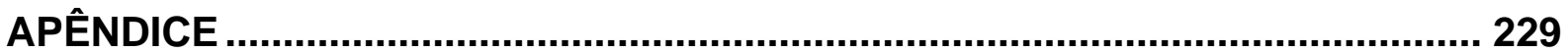




\section{INTRODUÇÃO}

A expressão "potencial turístico", assim como outras tidas como equivalentes ("aptidão" ou "vocação" turística), sofreu uma vulgarização que vem permeando não apenas o discurso político (qual é o prefeito ou secretário municipal de turismo que não acha que seu município tem "potencial turístico"?) e publicitário, mas também consolidando-se no meio acadêmico, o que se observa não apenas na prática de estudantes de graduação e pós-graduação em seus diferentes níveis, mas também - e o que é ainda mais grave - de docentes que propagam este conceito, aparentemente desprovido de qualquer sentido concreto.

Veja o texto a seguir, no qual Bissoli (2000, p. 48) explica o funcionamento do Programa Nacional de Municipalização do Turismo - PNMT:

O PNMT da EMBRATUR ${ }^{1}$ foi criado em 30 de março de 1994, de acordo com a Portaria Ministerial n.. 130, e implantado em agosto de 1995, para realizar uma série de ações que viabilizassem a implementação e a consolidação da descentralização das gestões turísticas. [...] O programa visa conscientizar os municípios sobre o fato de que somente possuir atrativos ou potencial turístico ${ }^{2}$ não é suficiente para que a atividade cresça $[\ldots]$.

Mais adiante, a autora afirma que "para integrar o PNMT é necessário que o município tenha vocação turística" (BISSOLI, 2000, p. 50-51) e, por fim, ao elencar as competências dos municípios quanto à atividade turística, recomenda "realizar levantamentos e análises das potencialidades turísticas do município".

\footnotetext{
1 Instituto Brasileiro de Turismo, órgão oficial do turismo brasileiro na ocasião, anteriormente denominado Empresa Brasileira de Turismo.

${ }^{2}$ Grifo nosso.
} 
Mas o que se deve entender, exatamente, por "potencial turístico", "vocação turística" ou "potencialidades turísticas"? O material documental não explicita tais conceitos e a academia também não os tem questionado.

Os levantamentos e análises eram elaborados com base, dentre outros instrumentos, no Roteiro de Informações Turísticas (RINTUR), considerado um elemento para a coleta de dados acerca da oferta turística dos municípios. (INSTITUTO BRASILEIRO DE TURISMO, [1996?], p. 2)

Visando dar cumprimento às atribuições conferidas à EMBRATUR no artigo $3^{\circ}$ da Lei n. 8.181 de 28 de março de 1991 e atendendo às diretrizes da Política Nacional de Turismo então vigente, o RINTUR constituía-se em instrumento normativo de seleção dos municípios prioritários para o desenvolvimento do turismo, capaz de embasar as ações de planejamento turístico em nível federal: em curto prazo, o governo deveria priorizar municípios para fins de alocação estratégica de recursos públicos no financiamento de empreendimentos turísticos e em médio e longo prazos, nortear as atividades de planejamento, voltadas ao desenvolvimento turístico municipal.

O último modelo vigente do RINTUR foi criado pela Deliberação Normativa $n^{\circ} 363$ de 27 de junho de 1996 e consistia em um conjunto de formulários com campos a serem preenchidos com dados sobre: 
- caracterização do município:

- nome e unidade da federação à qual pertence;

- $\quad$ distância da capital;

- $\quad$ área;

- $\quad$ população;

- $\quad$ limites municipais;

- $\quad$ clima;

- $\quad$ atividades econômicas;

- atividades turísticas então exploradas (turismo de negócios, desportivo, religioso etc.);

- $\quad$ atividades turísticas que poderiam ser exploradas;

- gestão turística:

- $\quad$ endereço da prefeitura municipal e nome do prefeito;

- $\quad$ dados do órgão municipal de turismo;

- dados sobre o plano de desenvolvimento, o conselho e o fundo municipal de turismo;

- $\quad$ existência de incentivos fiscais para o turismo;

- $\quad$ existência de inventário da oferta turística;

- $\quad$ existência de sinalização turística;

- $\quad$ ações de divulgação e promoção turística;

- $\quad$ programas dos quais o município participava (Programa Nacional de Municipalização do Turismo - PNMT; Programa do Artesanato Brasileiro - PAB; Programa Comunidade Solidária; Programa de Iniciação Escolar para o Turismo); 
- $\quad$ existência de legislação urbana, ambiental e de proteção do patrimônio histórico-cultural;

- infra-estrutura turística:

- $\quad$ serviços urbanos:

- energia elétrica;

- abastecimento de água;

- rede de esgoto;

- coleta de lixo;

- serviços de comunicação;

- serviços de transporte;

- serviços de saúde;

- serviços de segurança pública;

- meios de acesso ao município:

- $\quad$ rodoviário;

- aéreo;

- $\quad$ hidroviário;

- $\quad$ ferroviário;

- meio de acesso mais utilizado para chegar ao município;

- equipamentos e serviços turísticos:

- meios de hospedagem (incluindo campings e imóveis de temporada);

- $\quad$ serviços de alimentação;

- $\quad$ equipamentos de entretenimento e lazer;

- $\quad$ outros serviços turísticos;

- potenciais turísticos: 
- $\quad$ atrativos naturais;

- $\quad$ atrativos histórico-culturais;

- $\quad$ manifestações e tradições culturais;

- $\quad$ acontecimentos programados;

- $\quad$ centros científicos e técnicos;

- fluxo turístico:

- $\quad$ realização da coleta de dados sobre o fluxo turístico;

- aproveitamento dos dados coletados em benefício do desenvolvimento do turismo;

- aumento, diminuição ou estabilização do fluxo turístico nos últimos cinco anos;

- $\quad$ inclusão do município em roteiros turísticos.

$O$ relatório deveria ser entregue anualmente à EMBRATUR que, com base na análise das informações nele contidas, poderia acompanhar a evolução da atividade turística no país - foi levando em conta os RINTUR entregues em 1996, por exemplo, que a EMBRATUR produziu a publicação "Retrato do Brasil sob a Ótica dos Prefeitos do Municípios Brasileiros; fonte RINTUR ano base 1996", apresentando um "raio X" dos municípios turísticos brasileiros.

O RINTUR permitia, ainda, a classificação dos municípios brasileiros em:

- municípios turísticos (MT): aqueles consolidados, determinantes de um turismo efetivo, capaz de gerar deslocamentos e estadas de fluxo permanente; 
- municípios com potencial turístico (MPT): aqueles possuidores de recursos naturais e culturais expressivos, encontrando no turismo diretrizes para o desenvolvimento socioeconômico do município. ${ }^{3}$

Através da pesquisa, poder-se-ia nortear as administrações municipais sobre a importância da adoção de instrumentos técnicos adequados e de modelos de infraestrutura, institucionais e organizacionais, eficientes, tendo em vista viabilizar o desenvolvimento de sistemas locais de turismo de forma ordenada e sustentável.

A realização de uma pesquisa anual possibilitaria a reavaliação do "potencial" dos municípios já identificados pela EMBRATUR, bem como a identificação de novos municípios, favorecendo eventuais alterações quanto à prioridade, bem como a atualização dos dados municipais, fornecendo a real situação dos mesmos.

A listagem de municípios prioritários para o desenvolvimento do turismo no país, definidos em categorias (MT - município turístico e MPT - município com potencial turístico), era publicada anualmente no Diário Oficial da União, através de Deliberação Normativa.

Como se pode observar, o termo "vocação turística" é, também, um equivalente de "potencial turístico". Mas, afinal, o que isto quer dizer? A idéia de vocação alude a uma espécie de "dom natural" ou "divino" que a localidade possuiria e que, por si só, garantiria o surgimento e o desenvolvimento turístico.

\footnotetext{
${ }^{3}$ Grifo nosso.
} 
Ora, se assim o fosse, o planejamento seria desnecessário, uma vez que a localidade já reuniria as condições necessárias para que o turismo acontecesse, independentemente da ação humana - o que, como se sabe, nem sempre acontece e, quando acontece, vem de forma desorganizada, trazendo mais prejuízos que benefícios ao meio ambiente e à população local.

O mesmo ceticismo deve-se ter em relação à idéia de potencial turístico: se se parte da premissa de que "potencial" aproxima-se de "possível", como consta dos dicionários, então é possível admitir que tudo é potencial!

Alguém diria, ao analisar a pantanosa região da Flórida (EUA), que aquela área tinha algum potencial para se transformar em um dos maiores destinos turísticos mundiais? Ou que Las Vegas, antes um deserto, se tornaria símbolo do turismo de jogo no mundo? Nestes casos, o "potencial" foi, portanto, criado a partir de vultosos investimentos financeiros - não tendo nenhuma relação com uma suposta "dádiva" da natureza e deixando de ser "potencial" para ser uma "realidade".

De qualquer forma, a idéia de potencialidade apresenta-se bastante enraizada na bibliografia turística. Pellegrini Filho (1993, p. 34), após realizar pesquisas de 1970 a 1991, apresenta um inventário do patrimônio natural brasileiro, classificando seus elementos entre quatro tipos de potencialidade, como pode ser observado no quadro a seguir: 


\begin{tabular}{|c|c|}
\hline Tipos de Potencialidades & Características \\
\hline Potencialidade total & $\begin{array}{c}\text { Enormes potencialidades de aproveitamento, } \\
\text { indicando que nada ou quase nada existe de } \\
\text { realização racional }\end{array}$ \\
\hline Potencialidade fracamente realizada & $\begin{array}{c}\text { Grandes viabilidades de ampliação e/ou } \\
\text { melhoria do que já existe }\end{array}$ \\
\hline Potencialmente parcialmente realizada & Viabilidade de ampliação e melhoria \\
\hline Potencialidade realizada & $\begin{array}{c}\text { Restando em alguns casos poucas e } \\
\text { pequenas opções de acréscimo, sem } \\
\text { sobrecarregar equipamentos e serviços }\end{array}$ \\
\hline
\end{tabular}

Quadro 1 - Tipos de Potencialidades/Realização dos Atrativos Naturais

Fonte: PELLEGRINI FILHO, 1993, p. 34-35

Talvez o termo "aptidão" pudesse ser empregado com maior justeza à idéia que se quer expressar quando se fala em potencial ou vocação: ao reunir certas condições favoráveis ao desenvolvimento turístico, como facilidade de acesso, existência de atrativos ou de equipamentos e/ou serviços de entretenimento, poder-se-ia dizer que uma determinada localidade teria "aptidão" para o turismo diferentemente de outras que, apenas porque dispõem de recursos naturais ainda inexplorados pelo turismo, julgam-se "potenciais".

Acredita-se, assim, que a vulgarização da expressão "potencial turístico" se origina da ausência de uma definição mais precisa destes termos e da remota possibilidade de se avaliar de forma concreta este "potencial" nas localidades que se supõem turísticas com os métodos e instrumentos até agora criados para tal finalidade, como é o caso da metodologia proposta pela EMBRATUR para hierarquização ${ }^{4}$ dos atrativos turísticos.

\footnotetext{
4 "Hierarquização é o processo que permite ordenar os atrativos de acordo com a sua importância turística". (EMPRESA BRASILEIRA DE TURISMO, 1984, p.109)
} 
A crença na necessidade de se aprofundar a discussão sobre o tema encontra eco nas afirmações de outros estudiosos como Matheus (2003, p. 111) que, dentre algumas recomendações e sugestões que possam servir como tema para estudos mais avançados, defende, em sua tese de doutorado,

a importância do conhecimento da realidade quanto ao potencial turístico: detectar que a ótica errada do potencial turístico local pode provocar superdimensionamento dos projetos, resultando impactos negativos para o meio ambiente. A percepção errônea das características e das especificidades do território emperra a elaboração de uma oferta turística local sustentável.

Além dos riscos decorrentes da ausência ou inadequada percepção deste potencial ressaltados pela pesquisadora, pode-se supor que muitas vezes os responsáveis pelo turismo no âmbito municipal acreditam, ingenuamente, na fala demagógica daqueles que têm interesses econômico-financeiros nestes municípios (consultores ${ }^{5}$, por exemplo) ou realmente crêem, com base na oferta turística dessas localidades, que o turismo pode desenvolver-se, o que acaba levando estes municípios, muitas vezes, ao desperdício de recursos com a elaboração de planos, programas e projetos destinados ao fracasso - pois que desvinculados de uma real avaliação de sua necessidade - e a uma inútil mobilização de esforços das comunidades que, ao final do processo, sentem-se enganadas e/ou desiludidas com as expectativas criadas em torno do tão esperado desenvolvimento turístico.

\footnotetext{
${ }^{5}$ IGNARRA (1999, p.2) fala em "[...] magos 'fazedores de planos' [...]".
} 
Será que uma investigação mais criteriosa desta potencialidade turística não poderia evitar tantos investimentos malsucedidos? Foi com base nestas e em outras interrogações que surgiram ao longo da trajetória acadêmica e profissional do autor que se originou a proposta de realização deste estudo.

Durante a pesquisa, pudemos encontrar autores que começam a manifestar uma preocupação em tratar o assunto com maior seriedade, nem que seja de forma indicativa, como Matheus (já citada) ou Lemos (2001, p. 13):

No turismo, por fazer parte do sistema econômico, também é possível buscar respostas com base na análise de mudanças do 'estado das coisas' no presente. Como por exemplo:

Como saber se a nossa cidade tem potencial para produzir turismo?"

Outros autores, como Cooper et al. (2001) apresentam uma estrutura de planejamento turístico composta por diversas fases e, dentre elas, a fase de análise, que pressupõe:

- a avaliação do potencial turístico;

- a análise de mercado;

- o planejamento de desenvolvimento;

- as análises de impactos.

Fagliari e Almeida (2004, p. 32), que desenvolveram um rico estudo sobre a análise de atratividade e hierarquização de atrativos com ênfase na sistematização de métodos e propostas para atrativos culturais, afirmam que tal tipo de análise pode ser abordado a partir de diferentes óticas, resultando em métodos que vão da 
análise de destinos como um todo até aqueles que servem para classificação de componentes muito específicos da oferta turística, como a classificação de parques, por exemplo. Quanto aos métodos de análise de atratividade de destinos, as autoras os definem como os mais abrangentes em termos de escopo, em comparação aos demais.

Apesar da atual ênfase nos processos de regionalização do turismo em curso no país, as autoras, ao adotarem o município como foco de seu estudo, defendem que o conhecimento dos municípios brasileiros sobre seu potencial turístico ainda é muito pequeno.

Dizem (2004, p. 149) que "Por isso, acredita-se ser necessário que os municípios conheçam seu patrimônio e seu potencial de atratividade real, para também se organizarem individualmente e até mesmo antes de começarem a trabalhar em conjuntos maiores".

Feitas tais considerações, coloca-se, então, o problema central desta pesquisa: será que é possível avaliar o potencial para o desenvolvimento do turismo de lazer de um determinado destino para fins de seu planejamento turístico? Aqui cabe uma explicação quanto ao uso de alguns conceitos implícitos no neste problema.

Primeiramente, cabe uma reflexão sobre o uso da expressão "turismo de lazer" no problema da pesquisa: parece bastante claro que a existência de determinados fatores fundamentais para o desenvolvimento do ecoturismo, por exemplo (uma das várias manifestações do turismo de lazer) são muito diferentes daquelas 
necessárias ao turismo de negócios e/ou de eventos - razão pela qual torna-se necessário pensar em uma forma de restringir o problema de pesquisa a uma dimensão viável ${ }^{6}$.

Como definição de destino turístico, pode-se mencionar a de Bull (1994 apud SANCHO, 1998, p. 53), que o define como "país, região ou cidade para o qual se dirigem os visitantes, tendo-o como seu principal objetivo" e a de Cooper et al. (1993 apud SANCHO, 1998, p. 53), que o definem como a "concentração de instalações e serviços desenhados para satisfazer as necessidades dos turistas"; embora as definições acima possam ser vistas como complementares, para fins desta tese, deve-se entender como destino turístico o município - embora Sancho (1998, p. 53) afirme que a expressão "município turístico" é fictícia, já que o turista não enxerga e/ou não respeita limites ou demarcações e que, além disso, nem todo município onde se desenvolva uma atividade pontual de interesse turístico pode ser classificado como município turístico.

Segundo, ainda, o mesmo autor, a noção de destino turístico parece mais adequada para referir-se ao espaço geográfico em questão ao introduzir um elemento dinâmico no conceito: "ao falar de destino faz-se referência a um lugar de chegada, de acolhida (accuei), de recepção em definitivo dos visitantes" (SANCHO, 1998, p. 53), ou seja, explicita um dos elementos determinantes para a experiência turística, que é o deslocamento.

\footnotetext{
${ }^{6}$ Pearce (1991, p. 113), por exemplo, aborda e exemplifica as particularidades do planejamento local de centros costeiros, de áreas urbanas e de cidades históricas; e Casal (2002, p. 243-314) trata do planejamento do turismo alternativo.
} 
O recente reconhecimento da importância do turismo, tanto como fenômeno quanto como atividade, fez surgir no Brasil e no exterior um significativo mercado editorial nesta área, no qual se destacam algumas obras já consideradas fundamentais no estudo do turismo, algumas das quais diretamente ligadas à área de planejamento turístico - outra expressão inserida no problema desta pesquisa , que permearam a elaboração deste projeto.

Uma destas obras é a de Beni (2000, p. 99) que reforça a premência deste tipo de estudo, ao defender que:

No Brasil, diferentemente do que ocorre em países em desenvolvimento na África e na Ásia, observou-se até recentemente marcante ausência de pesquisas científicas e um quase menosprezado conhecimento teórico do fato e do fenômeno turístico, provocando improvisada ação no setor, com evidentes reflexos e conseqüências de minguada presença de sensibilidade do poder público, sobretudo das áreas responsáveis pelo desenvolvimento do turismo, aliada a uma sensível indiferença para com a Universidade e as áreas de investigação [...].

Outra obra de referência na área é a de Ruschmann (1997), que apresenta os conceitos fundamentais de planejamento turístico e sua importância para a preservação do meio ambiente, permeada de exemplos reais em que ficam evidenciadas as relações entre turismo, planejamento e meio ambiente.

Em outra de suas obras, a autora (2001, p. 67), afirma que o planejamento turístico deve ser entendido como

[...] o processo que tem como finalidade ordenar as ações humanas sobre uma localidade turística, bem como direcionar a construção de equipamentos e facilidades, de forma adequada, evitando efeitos negativos nos recursos que possam destruir ou afetar sua atratividade.

Ruschmann diz ainda (1997, p. 84) que a atividade 
constitui $o$ instrumento fundamental na determinação e seleção das prioridades para a evolução harmoniosa da atividade turística, determinando suas dimensões ideais para que, a partir daí, se possa estimular, regular ou restringir sua evolução.

Com base no levantamento bibliográfico até aqui conduzido, na análise de material documental (governamental, principalmente) e na experiência pessoal docente, acredita-se que:

- a expressão "potencial turístico" é utilizada de maneira vaga, imprecisa e, por vezes, incorreta, possivelmente devido a uma inadequada compreensão de seu significado;

- uma vez adequadamente definida a expressão, talvez seja possível, por meio de um instrumento específico, avaliar em que consiste o potencial para o desenvolvimento do turismo receptivo de lazer de determinados destinos, tanto do ponto de vista qualitativo (condições para que se possa falar, efetivamente, na existência deste potencial) como quantitativo (nível ou grau de "potencialidade").

Mas restam, ainda, algumas dúvidas: como se deve proceder a esta análise? Quais variáveis e parâmetros devem ser utilizados para tanto? Como este conhecimento pode chegar às mãos dos possíveis realizadores destes estudos e/ou dos maiores beneficiados por tais análises? São perguntas subjacentes ao problema central desta pesquisa que, espera-se, encontrarão respostas a partir da aplicação do método proposto a seguir. 
Desta forma, a presente tese tem por objetivo principal/geral identificar as possibilidades de uma factível e confiável avaliação do potencial turístico de localidades receptoras.

Como objetivos secundários/específicos, pretendemos:

- analisar a abordagem do objeto de estudo nas bibliografias nacional e internacional específicas;

- propor a formulação e a utilização de um instrumento de avaliação do potencial turístico de localidades receptoras, a fim de minimizar o caráter subjetivo predominante neste tipo de análise;

Temos como objetivos teóricos:

- sistematizar um instrumento de referência para o estudo e a prática do planejamento turístico, suas possibilidades de utilização e possíveis limitações;

- possibilitar a expansão do conhecimento sobre a área de planejamento turístico, a partir da abertura do espaço para a discussão sobre o tema no âmbito acadêmico;

Apresentam-se como objetivos práticos:

- oferecer a possibilidade de um melhor direcionamento dos recursos e das ações para o planejamento da atividade turística a partir da possível 
constatação a priori da existência de condições que justificariam este direcionamento;

- proporcionar aos administradores públicos do turismo condições para uma melhor utilização do planejamento turístico como instrumento para o desenvolvimento de seus municípios.

Os procedimentos adotados para a confirmação ou rejeição das hipóteses formuladas são:

- pesquisa bibliográfica exploratória sobre o tema, com levantamento da bibliografia pertinente para a constituição do referencial teórico;

- definição dos municípios-objetos de estudo;

- pesquisa bibliográfica e de campo sobre os municípios-objetos de estudo;

- formulação do instrumento de avaliação do potencial turístico, a partir da definição das variáveis a serem identificadas e de sua operacionalização;

- desenvolvimento e aplicação do instrumento de avaliação do potencial turístico proposto nos municípios escolhidos;

- análise dos dados e cruzamento das informações obtidas com o referencial teórico constituído inicialmente.

A avaliação final é que estes procedimentos mostraram-se compatíveis com os objetivos a serem alcançados, bem como com os resultados esperados, em função do tipo de pesquisa que se pretendeu realizar. 
Como já mencionado, aparentemente inexistem estudos acadêmicos específicos sobre o tema sob a perspectiva aqui adotada, razão pela qual as principais referências encontram-se não em teses ou dissertações, mas, principalmente, em publicações de autores brasileiros e, sobretudo, estrangeiros.

Bissoli (2000), em sua obra sobre planejamento turístico, apresenta também os conceitos básicos sobre a área, destacando as metodologias para o planejamento turístico e o uso dos sistemas de informação para a elaboração de planos municipais de desenvolvimento turístico e apresentando, ainda, alguns estudos de casos elaborados pelo Curso de Turismo da Pontifícia Universidade Católica de Campinas (PUCCAMP).

Em âmbito internacional merecem destaque, além dos autores já citados anteriormente (PEARCE, 1991 e COOPER et al., 2001), alguns autores de renomada importância na área de planejamento turístico, como Sessa (1983), Boullón (1995, 1998 e 2002), Molina (1997), Acerenza (1998), Inskeep (1991) e outros cujas obras passaram a receber maior destaque na atualidade, como Swarbrooke (2000), também preocupado em relacionar planejamento turístico e sustentabilidade.

Não se pode deixar, ainda, de mencionar autores que dedicaram partes de algumas de suas obras ao objeto de estudo ora enfocado - a discussão sobre potencial turístico e as tentativas de buscar mensurá-lo -, são eles: Baud-Bovy \& Lawson (1977 e 2002), Gunn (1980 e 1988), Smith (1989 e 1992), Pearce (1991) e Pearce \& Butter (2002). 
Mas, sem dúvida alguma, o autor com a contribuição mais consistente sobre o tema ora estudado é Leno Cerro (1993), que dedicou uma obra inteira sobre o assunto - a única identificada na literatura internacional com tal característica, ainda que o autor abarque sob tal título diversas possibilidades de avaliações que, combinadas, podem levar à análise do potencial turístico de localidades como um todo pois, na realidade, a ênfase de sua obra (assim como a da maioria dos autores pesquisados) está na avaliação dos recursos turísticos.

Pode-se dizer, pois, que uma das maiores dificuldades encontradas foi a localização de referencial bibliográfico (tanto em língua portuguesa como estrangeira) que abordasse o tema em profundidade já que, como mencionado, o que se vê, na maior parte das obras, é apenas a menção à idéia de potencial turístico - o que não deixa de ser útil, justamente pela possibilidade de análise e crítica de seu uso. Todavia, tal dificuldade foi superada com a identificação das obras anteriormente mencionadas que permitiram a redação do marco teórico da tese.

Diante do exposto anteriormente, este trabalho encontra-se assim constituído:

- Introdução: apresenta o tema e o problema da pesquisa, as razões que conduziram à escolha deste tema, os procedimentos adotados para a realização da pesquisa, a estrutura do texto (organização e divisão dos capítulos) e os resultados obtidos; 
- Revisão teórico-metodológica": o capítulo apresenta a visão dos pesquisadores de destaque sobre o assunto de forma a se definir a expressão da forma mais adequada possível;

- Contextualização e delineamento dos municípios-objetos de estudo: apresenta os municípios escolhidos para aplicação do instrumento proposto (Guaratinguetá e Cunha/SP), bem como da justificativa da escolha destes municípios e sua relação com os programas e projetos governamentais (em âmbito federal) nos quais estão inseridos;

- Pesquisa: formulação e aplicação do instrumento de avaliação do potencial para o desenvolvimento do turismo de lazer das localidades escolhidas: exposição dos métodos que conduziram à formulação de um instrumento de avaliação do potencial turístico de localidades receptoras e o resultado da aplicação do instrumento proposto nos municípios de Guaratinguetá e Cunha/SP;

- Considerações finais: relaciona o quadro teórico que fundamentou o início das atividades de pesquisa com os dados obtidos através da pesquisa de campo, a fim de se oferecer uma possível resposta para o problema formulado, confirmando-se ou rejeitando-se as hipóteses formuladas.

Espera-se (O BRASILEIRO, 2002) que o Brasil receba, em 2010, dez milhões de turistas estrangeiros, alcançando o $18^{\circ}$ posto entre os maiores receptores de turistas no ranking da Organização Mundial do Turismo (OMT) - números que levam a uma reflexão sobre os efeitos que a atividade turística pode trazer sobre as áreas por ela afetadas, particularmente no âmbito municipal, uma vez que é nos municípios que a atividade turística efetivamente acontece. Tal afirmação merece 
uma observação ainda mais cuidadosa quando analisada à luz das projeções da OMT, segundo a qual, até o final da segunda década do século, $75 \%$ das viagens terão curta duração.

Tal configuração do panorama mundial e nacional remetem, imediatamente, à preocupação que começa a manifestar-se tanto por parte da iniciativa privada como, e principalmente, pelo poder público, com a qualidade dos produtos turísticos brasileiros a serem oferecidos para esta demanda, cada vez mais ávida por novas experiências turísticas, expectativa que se coaduna com os objetivos do planejamento turístico, desde que adequadamente conduzido.

A partir deste momento, vê-se a atividade de planejamento turístico florescer como um grande mercado de trabalho: destacam-se empresas prestadoras de serviços de consultoria turística e vêem-se surgir outras tantas voltadas para atuação na área em todo o país, bem como entidades e instituições como o Serviço Brasileiro de Apoio às Micro e Pequenas Empresas - SEBRAE e o Centro de Estudos e Pesquisas da Administração Municipal Fundação Prefeito Faria Lima - CEPAM, órgão da Secretaria de Planejamento do Estado de São Paulo.

As instituições de ensino superior de turismo, por sua vez, direcionam seus currículos para o planejamento turístico, passando, muitas instituições, a elaborar planos, programas e projetos de desenvolvimento turístico para diversos municípios. Da mesma forma, os cursos de pós-graduação na área passam a ter uma grande procura. 
O que não se sabe, entretanto, é como esta demanda por planejamento reflete-se na prática no país, ou seja, em que medida o estímulo a esta atividade trouxe benefícios para o desenvolvimento turístico brasileiro, uma vez que tal "desenvolvimento" está, em alguns casos, baseado em conceitos imprecisos e em um tratamento leviano do tema - razão pela qual propõe-se este estudo.

Reconhece-se que é grande o desafio aqui relatado, ainda mais diante da constatação de que se trata da necessidade de uma abordagem interdisciplinar do problema exposto, envolvendo questões de geografia, economia, marketing, ciências exatas e outras ciências que devem fornecer a base conceitual desta proposta - o que a torna ainda mais desafiadora e interessante, além de necessária de acordo com a perspectiva aqui adotada, que vai ao encontro das expressões da bibliografia nacional e internacional.

Uma vez estruturado um instrumento adequado de avaliação do potencial turístico, acredita-se ser possível ainda, a título de complementação (não, porém, como objetivo central) disponibilizar este instrumento através de um sistema informatizado de apoio à decisão que, segundo Bissoli (2000, p. 114),

[...] pode ser utilizado não só para indicar quais decisões devem ser tomadas como também para alertar sobre as possíveis conseqüências da aplicação de uma determinada medida, o que oferecerá vantagens competitivas no processo de decisão, diminuição de erros e maior rapidez $[\ldots]$.

Acredita-se que esta aplicação poderia tornar-se de mais fácil acesso aos interessados, além de dinamizar e facilitar o seu uso por meio da eliminação da necessidade de se realizar manualmente parte dos procedimentos necessários à 
avaliação, a exemplo do que propõe Hammes (1998) para fins de zoneamento ambiental e turístico.

Convém ressaltar que inexistem pesquisas sobre o tema proposto - característica exigida para um projeto de pesquisa em nível de doutorado - razão pela qual se espera, através deste estudo, alcançar os objetivos anteriormente propostos.

Espera-se, ainda, que os resultados desta pesquisa consigam mostrar que a academia pode (e, por que não dizer deve?) contribuir para o aperfeiçoamento metodológico não apenas dos acadêmicos, mas também, dos "praticantes" do turismo que, segundo Jenkins (2002, p. 69-72), são os consultores individuais e as firmas de consultoria - grupos que, na visão do autor, não interagem, resultando que a academia raramente - se é que isto acontece - influencia o desenvolvimento do turismo.

O autor ainda destaca (2002, p. 71) que

"A necessidade de publicar jornais acadêmicos e livros de assuntos específicos procura influenciar (se não impressionar) o grupo de colegas acadêmicos. A disseminação da informação é essencialmente escolar e motivada para a carreira. Alguns dos debates centrais e contínuos [...] fazem progredir nossa compreensão teórica do assunto, mas não parecem ser de grande interesse dos praticantes. [...] Deve existir ainda outro problema: os praticantes de turismo não lêem a literatura acadêmica. [...] Muito do trabalho inovador que está sendo feito por acadêmicos provavelmente influenciará muito pouco a prática do desenvolvimento do turismo, a menos que o acadêmico também seja um praticante $^{7 "}$.

\footnotetext{
${ }^{7}$ O que é bastante comum no Brasil - boa parte dos docentes do ensino superior de turismo atuam também como consultores.
} 
É, portanto, com o intuito de contribuir para minimizar os efeitos desta dicotomia que é apresentada a seguir a pesquisa ora proposta. 


\section{REVISÃO TEÓRICO-METODOLÓGICA}

Antes de mais nada, convém aqui salientar a quase total inexistência de pesquisas sobre o assunto ora estudado. Embora, como se pôde ver na introdução deste trabalho, vários autores reafirmem a necessidade dos estudos de potencialidade turística, poucos foram aqueles que avançaram em direção à construção de referenciais para tal análise.

Smith (1992, p. 19), ao iniciar a discussão sobre os problemas que cercam a investigação descritiva de lugares, afirma que o problema de nomear, descrever e classificar os recursos recreativos ${ }^{8}$ e sua exploração é um problema complexo e de múltiplas facetas e que, embora todos os pesquisadores concordem com tal afirmação, todos eles estão de acordo também com tal necessidade, porém não coincidem quanto à utilização de um sistema único de classificação.

Diante disto, o autor afirma que os métodos de análise da localização dos recursos recreativos e as atividades que neles se realizam são tão numerosos quanto os fins para os quais são aplicados e propõe o agrupamento destes métodos em três categorias principais: descrição da localização de instalações e atividades, inventário dos recursos e descrição das imagens das regiões e seus recursos. Smith diz ainda (1992, p. 20) que,

\footnotetext{
${ }^{8}$ Devido ao fato de terem sido utilizadas diversas fontes para a redação deste capítulo, serão utilizadas diversas palavras ou expressões que, para fins desta tese, devem ter o mesmo significado: recursos turísticos, recursos recreativos e atrativos turísticos. Embora a literatura especializada registre as diferenças que, em alguns casos, devem ser observadas para fins do planejamento turístico, acredita-se que aqui tais diferenças possam ser desconsideradas, dadas as diferentes formações dos autores consultados (geógrafos, urbanistas, economistas etc.) e as possibilidades de mudanças dos termos nas traduções.
} 
O ordenamento destes três temas reflete sua evolução histórica, pois o uso recreativo do solo foi o primeiro aspecto da matéria que atraiu a atenção dos geógrafos. O turismo e a recreação foram reconhecidos como importantes contribuições para as economias locais desde a década dos anos 20. Este interesse logo propiciou a identificação de recursos que poderiam ser sujeitos de desenvolvimento futuro. Finalmente, ao darem-se conta da relação que há entre um recurso e que seu uso está sujeito à peneira dos valores humanos, os investigadores se consagraram a analisar a função das imagens e percepções na exploração de tais recursos. Atualmente, as distinções entre estes temas na bibliografia não são tão definidas [...], mas sua estrutura ajuda a ordenar a complexa história de um aspecto da geografia recreativa.

Em função disso, opta por dividir os métodos e técnicas de investigação descritiva de lugares da seguinte maneira:

- descrição da localização de instalações e atividades:

- localização de instalações;

- localização de atividades;

- inventário de recursos:

- métodos aritméticos;

- métodos separativos;

- métodos aglomerativos;

- imagens de regiões e recursos:

- descrição espontânea;

- descrição preferencial;

- técnicas de avaliação.

Algumas explicações adicionais talvez sejam bem-vindas no sentido de possibilitar melhor compreensão da classificação de Smith e os métodos a seguir apresentados. Segundo o autor, 
- o método aritmético é o mais simples para o inventário de recursos, e consiste em delimitá-los e quantificá-los em seguida, nos casos em que o interesse do pesquisador esteja centrado na simples presença física de recursos ou no potencial de uma região para ser sujeito de alguma forma de recreação. Neste sentido, diz (1992, p. 26) que "o inventário de recursos pode efetuar-se por meio da simples enumeração ou mediante a criação de modelos de 'sistemas' mais ou menos complexos que combinem de forma aritmética variáveis descritivas";

os métodos mais avançados para o inventário de recursos incluem as classificações separativas e aglomerativas.

A primeira consiste no processo de dividir uma região ou um grupo de recursos em subgrupos específicos; ao passo que a segunda é o inverso, isto é, os recursos se agrupam em categorias mais gerais. O autor destaca (SMITH, 1992, p. 36) que

A separação é útil quando se tem uma compreensão razoável do padrão geral e se deseja agregar precisão mediante a identificação de subunidades dentro deste total. Esta requer uma estrutura teórica ou uma série de regras que permitam a divisão e subdivisão de um fenômeno em categorias mutuamente excludentes. Mediante tais regras, identifica-se a maneira com que se relacionam estas categorias em um nível determinado e entre níveis inclusive, e indicam quando deve-se parar o processo de separação.

Quanto aos métodos aglomerativos, diz que "em geral, os requisitos para este tipo de método são os mesmos que para os separativos, a exceção da necessidade do investigador de compreender teoricamente o "total" final da descrição, que neste caso é o produto final" (SMITH, 1992, p. 39). 
Leno Cerro (1993, p. 51-136) também comenta as possibilidades de aplicação do inventário turístico e da análise da paisagem com tal finalidade; todavia, o autor dá grande destaque, em boa parte sua obra sobre técnicas de avaliação do potencial turístico, a técnicas de avaliação dos recursos turísticos, que se subdividem em:

- avaliação analítica do potencial turístico;

- avaliação econômica dos recursos;

- preferências dos usuários como medida de avaliação turística.

Segundo o autor,

Os métodos de classificação e inventário dos recursos constituem os primeiros passos na análise do potencial turístico de uma zona, facilitando a identificação daqueles elementos ou atividades que têm um certo poder atual ou potencial para atrair a demanda turística. Sem dúvida, o valor real do potencial turístico de uma área não se mede unicamente pelo número de atrativos que reúne, mas também pela qualidade deles. Este é precisamente o objetivo das técnicas de avaliação dos recursos que, como em qualquer outra atividade a planejar, têm como fim básico estabelecer uma medida de valor sobre a qual fundamentar a tomada de decisões no processo planificador (LENO CERRO, 1993, p. 51).

O autor afirma ainda que estes tipos de técnicas começaram a ser aplicadas no final da década dos anos 60 com uma orientação para o setor turístico na Europa e para os recursos recreativos, em geral, na América do Norte, tomando como modelo básico de referência as técnicas de avaliação paisagística, desenvolvidas por arquitetos paisagistas e geógrafos. Todavia, segundo o autor, até o início dos anos 90 não se podia afirmar categoricamente que o trabalho de avaliação dos recursos turísticos, em particular, ou do potencial turístico de uma zona, em geral, fosse uma questão resolvida. De acordo com ele (LENO CERRO, 1993, p. 52), 
Com efeito, a natureza diversa e com freqüência intangível destes recursos, unida à inevitável carga de subjetividade que é tolerada em toda valoração estética, têm dificultado enormemente a elaboração de uma metodologia de aplicação universal que permita uma valoração racional e sistemática destes tipos de recursos.

Leno Cerro afirma ainda, por outro lado, existe um certo nível de acordo entre os especialistas acerca de um grupo de fatores sobre os quais tal avaliação pode se fundamentar e apresenta, a título de exemplo, três critérios básicos de valoração definidos pela União Internacional dos Órgãos Oficiais de Turismo (UIOOT) ${ }^{9} \mathrm{em}$ um estudo relativo à oferta potencial de recursos turísticos em nível mundial:

- o grau de interesse que desperta o recurso sobre a demanda;

- a raridade ou originalidade do recurso;

- sua disponibilidade no tempo.

Sua opinião é de que

Estes critérios estão presentes, implícita ou explicitamente, em quase totalidade dos métodos de avaliação de recursos, ainda que a forma pela qual são analisados e a importância que se concede a cada um deles varia sensivelmente em função do enfoque adotado pelo planejador. Neste sentido, pode-se diferenciar três enfoques básicos ${ }^{10}$, ainda que, como é lógico, a maior parte de tais métodos incluem elementos de cada um deles (LENO CERRO, 1993, p. 52).

A avaliação analítica do potencial turístico pode ser aplicada a um amplo conjunto de técnicas de avaliação cujo denominador comum é a hipótese de que, considerando a presença ou ausência de determinados componentes e valorando cada um deles, pode-se chegar a uma avaliação da qualidade turística de um recurso particular ou de uma área com vocação turística.

${ }^{9}$ Esta organização, posteriormente, deu origem à OMT. 
Trata-se, pois, de atribuir o valor intrínseco do próprio recurso com base em suas principais características, a partir das quais se obtém um índice de qualidade comparável ao calculado para outras áreas ou recursos mais ou menos parecidos. Leno Cerro diz (1993, p. 76) que

Por outro lado, os estudos baseados na avaliação econômica de recursos começam a se desenvolver nos Estados Unidos da América durante os últimos anos da década dos anos 50 a partir das análises da demanda em áreas recreativas, desembocando, anos mais tarde, durante a década dos anos 60 e, sobretudo, a partir dos anos 70, em modelos de estimação dos benefícios econômicos da atividade recreativa em áreas naturais. O objetivo final deste tipo de técnica é estabelecer uma metodologia que permita, a partir de um ponto de vista econômico, tomar decisões sobre possíveis usos, alternativos e incompatíveis, em uma determinada área. Trata-se de formular uma série de ferramentas que permitam uma avaliação econômica daqueles recursos que não são de caráter comercial e que, portanto, não têm um preço no mercado, aplicando-se para tanto, técnicas e conceitos da teoria econômica convencional a situações não convencionais.

Já a análise das preferências dos usuários como medida de avaliação turística, segundo o autor (1993, p. 102), parte do suposto lógico que, quanto maior for o valor de um determinado recurso ou destino turístico, maior interesse ele despertará entre seus usuários potenciais.

O teórico aponta (LENO CERRO, 1993, p. 102) que

Esta hipótese básica, que em definitivo relaciona o valor de um bem ofertado (recurso) com a demanda que gera (movimento turístico), está subjacente à maior parte das técnicas analisadas anteriormente [...], mas, ao contrário daquelas, neste caso não se contempla como instrumento de medida os níveis de participação ou uso de um recurso de medida os níveis de participação ou uso de um recurso ou destino turístico concreto, mas sim as preferências expressadas pelos turistas reais ou potenciais de tal recurso.

${ }^{10}$ Citados na página anterior. 
Assim, apresentam-se a seguir alguns referenciais teórico-metodológicos que abordam de forma explícita o tema aqui tratado, e que podem subsidiar o enriquecimento da discussão e da proposta metodológica - objeto desta tese.

De acordo com a classificação proposta por Smith, é possível observar que a maior parte dos métodos inclui-se nas categorias descrição da localização de instalações e atividades ou inventário dos recursos - optou-se por deixar de lado, nesta tese, a análise da paisagem (embora tal método já seja utilizado para a análise do potencial turístico, como será mencionado mais adiante) dada a necessidade de formação específica para a aplicação de tal método.

Embora seja possível encontrar alguns autores que se dedicaram a propor métodos e técnicas de inventário, análise e avaliação de elementos que podem vir a compor o chamado "potencial turístico", como os atrativos ou os equipamentos e serviços turísticos, optou-se, nesta tese, por desconsiderar aqueles que se referem exclusivamente a uma ou outra categoria da oferta turística isoladamente, exceto quando tal análise apresentar alguma possibilidade de contribuição à visão de conjunto que orienta esta tese, seja no raciocínio teórico, seja na proposta instrumental-metodológica.

Da mesma forma, também deixaram de ser citados nesta parte da pesquisa aqueles autores que abordaram o assunto de forma apenas teórica - muitos dos quais já mencionados na introdução. Evidentemente, não se trata de desprezo a tais abordagens, mas sim de um meio de possibilitar um avanço na análise do ferramental mais diretamente vinculado a este trabalho. 


\subsection{O Grau de Atração Turística de Pinzan}

Um dos autores que tentaram desenvolver algumas propostas neste sentido foi Pinzan (2003) que, na realidade, ao tentar analisar a potencialidade da atividade turística para o desenvolvimento da Região Metropolitana da Baixada Santista, tendo em mente sua interação espacial com a Região Metropolitana de São Paulo, desenvolveu uma metodologia para definir o grau de atração de cada município sobre o fluxo de visitantes - todavia, este foi apenas um dos componentes necessários à análise ${ }^{11}$. De acordo com o autor (PINZAN, 2003, p. 102-103).

É importante observar que qualquer determinação de um indicador que quantifique o valor a partir dos atrativos naturais na atividade turística encontra, de antemão, diversas dificuldades. Pelo fato de esse recursos apresentarem uma multiplicidade de aspectos e dos diferentes interesses, Cunha (1987) aponta que encontrar um método de avaliação aceitável a todos consiste num problema. O que devemos avaliar? O equilíbrio do ecossistema? A qualidade visual? A utilização turística? Além disso, colabora para essa dificuldade a ótica de quem e para quem se avaliam os recursos. Assim, ecologistas, geógrafos, planejadores, entre outros, podem ter posições diferentes sobre o uso e o valor dos mesmos recursos. Portanto, a avaliação dos recursos naturais em turismo pode estar carregada de subjetividade e não corresponder a uma racionalidade como, por exemplo, as exigidas pelo mercado.

O autor cita (PINZAN, 2003, p. 103) outro fato que se soma a essa dificuldades: os atrativos naturais têm ordens de importância variáveis, "[...] ou seja, para a atividade turística o fluxo de visitantes a um local pode ser determinado por seu grau de atração, numa escala internacional, nacional e regional”.

Para sua análise, Pinzan considerou o período de novembro de 1999 a outubro de 2000 (ciclo de 12 meses), restringiu sua observação apenas aos atrativos da 
Região Metropolitana da Baixada Santista e tomou a praia como elemento central, visto que a região em análise caracteriza-se pelo turismo de verão, tendo a praia como elemento central - foram desconsiderados, pois, os atrativos culturais e o uso de serviços relacionados ao turismo (agências de viagens, aluguel de veículos etc.) e de alimentação. O autor mostra (2003, p. 103-104) que

A partir das informações contidas no Sumário de Dados da Região Metropolitana da Baixada Santista, elaborado pela [Empresa Metropolitana de Planejamento S.A. - EMPLASA], determinamos o fator de influência do recurso turístico natural - a praia - para identificar o seu peso no grau de atração turística de cada município. Para tanto, consideramos o número de praias e a extensão de linha de praia de cada município e estabelecemos a seguinte relação:

$$
\operatorname{Atm}=[(P \times E) \times 100]
$$

Onde:

$A_{t m}=$ peso do atrativo turístico natural do município;

$\mathrm{P}=$ número total de praias de cada município ${ }^{12}$;

$E=$ extensão da linha de praia de cada município.

Desta forma, por exemplo, o autor obteve, como peso do atrativo turístico natural (praias) o valor de 70.200 para o município de Peruíbe (que tem $39 \mathrm{~km}$ de extensão de linha em 18 praias) e 38.000 para o município de Guarujá (que tem $19 \mathrm{~km}$ de extensão de linha em 20 praias).

Para determinar o grau de atração turística de um município $\left(G_{A T}\right)$, Pinzan somou os números obtidos pela relação anterior com o número de alojamentos ${ }^{13}$ e os

\footnotetext{
${ }^{11}$ Os demais foram: a contabilidade municipal, através das receitas; o estoque de mão-de-obra; o fluxo de veículos em direção à região e o consumo de água (PINZAN, 2003, p.91).

12 Para a definição da variável $P$, o autor desconsiderou fatores como a limpidez, localização, acessibilidade e outros fatores que poderiam levar a uma diferenciação do grau de atração de uma praia para outra - fatores, esses, que influenciam em boa medida, segundo análise do próprio autor, o fluxo turístico. "Entendemos que isso não anula a variável, mas isola os fatores subjetivos e indica a propensão que os recursos de cada município têm para atrair turistas" (PINZAN, 2003, p.104).
} 
domicílios de uso ocasional ${ }^{14}$, dividindo, em seguida, o resultado pelo fluxo turístico (estabelecido pela média mensal de veículos de passeio, na alta temporada, menos a média mensal da baixa temporada).

Assim temos (PINZAN, 2003, p. 105):

$$
G_{A T}=\left[\frac{A_{t m}+\left(R_{H}+R_{O}\right)}{F_{T}}\right]
$$

Onde:

$A_{\mathrm{tm}}=$ peso do atrativo turístico natural do município;

$\mathbf{R}_{H}=$ número médio de alojamento $X$ média de leitos $X$ média de unidades;

$\mathbf{R}_{\mathrm{O}}=$ número de domicílios de uso ocasional $\mathrm{X}$ média de habitantes por domicílio regulares;

$F_{\mathrm{T}}=$ fluxo turístico.

Sendo que:

$$
F t=m a t-m b t
$$

Onde:

$m_{\mathrm{at}}=$ média mensal do fluxo de veículos da alta temporada;

$\mathrm{m}_{\mathrm{bt}}=$ média mensal do fluxo de veículos da baixa temporada.

Como exemplo, o autor demonstra (PINZAN, 2003, p. 105) a aplicação de seus cálculos ao município de Bertioga:

$$
\begin{aligned}
& \text { Atm }=25.200 \\
& \mathrm{R}_{\mathrm{H}}=(75 \times 3,7 \times 17,2)=4.773 \\
& \mathrm{R}_{\mathrm{O}}=(15.691 \times 3,2)=50.211 \\
& \mathrm{~F}_{\mathrm{T}}=1.080 .532-859.995=220.537
\end{aligned}
$$

\footnotetext{
${ }^{13}$ Variável composta pelo número de estabelecimentos do setor multiplicado pelo número médio de leitos oferecidos e pelo número médio de unidades de hospedagem por estabelecimento da região. "O fator de multiplicação encontrado foi de 3,7 leitos por unidade habitacional e 17,2 unidades habitacionais por estabelecimento" (PINZAN, 2003, p.104).
} 
A partir dos resultados encontrados, chega à classificação exposta a seguir.

\begin{tabular}{|c|c|}
\hline MUNICíPIO & GRAU DE ATRAÇÃO \\
\hline Praia Grande & 1,46 \\
\hline Guarujá & 0,84 \\
\hline Peruíbe & 0,55 \\
\hline Itanhaém & 0,50 \\
\hline Mongaguá & 0,42 \\
\hline Bertioga & 0,38 \\
\hline Santos & 0,32 \\
\hline São Vicente & 0,23 \\
\hline Cubatão & 0,005 \\
\hline
\end{tabular}

Quadro 2 - Grau de atração turística dos municípios da Região Metropolitana da Baixada Santista (em ordem decrescente)

Fonte: PINZAN, 2003, p. 106.

Para validar os resultados obtidos, o autor comparou (PINZAN, 2003, p. 106) os dados supramencionados com os levantados por uma pesquisa da empresa Desenvolvimento Rodoviário S.A. - DERSA realizada no feriado de 25/01/1997 e encontrou uma compatibilidade entre o modelo e a realidade - mesmo considerando que uma pesquisa realizada em apenas um feriado pode apresentar viés nos resultados. Pinzan (2003, p. 107) aponta que

O grau de atração demonstra a potencialidade que cada município tem para atrair turistas, a partir de seus atrativos naturais e de sua capacidade de alojamento. Fica evidente também, neste estudo, a influência que as segundas moradias têm no fluxo turístico da região.

Embora o estudo de Pinzan não trate especificamente do tema desta tese, por restringir-se a uma análise que considera apenas um tipo de atrativo em especial (praia) e, parcialmente, a estrutura de hospedagem, é interessante observar a tentativa de possibilitar, de forma objetiva, por meio da seleção criteriosas de variáveis disponíveis, a análise a que se propõe o autor.

${ }^{14}$ Obtidos junto ao Censo 2000 do Instituto Brasileiro de Geografia e Estatística - IBGE e multiplicados pela ocupação média dos domicílios com habitantes regulares da região, cujo valor é 


\subsection{A Matriz de Avaliação do Projeto Pólos de Desenvolvimento de Ecoturismo no Brasil}

O Projeto Pólos de Desenvolvimento do Ecoturismo no Brasil, da EMBRATUR e do Instituto de Ecoturismo no Brasil - IEB, iniciou-se em 1997 com o objetivo de identificar as localidades brasileiras onde a prática do ecoturismo já vinha ocorrendo com algum sucesso e fazer um levantamento das características, potencialidades e condições de infra-estrutura nos locais onde o ecoturismo se apresentava como uma nova alternativa de desenvolvimento (MAGALHÃES, 2001, p. 65) e deu origem, dentre outros resultados, a um documento que pudesse servir de subsídio aos interessados no planejamento das atividades ecoturísticas.

Dentre as várias questões que envolvem o planejamento e implantação de um pólo ecoturístico - condições iniciais para criação do pólo, inventário e análise de recursos, avaliação dos impactos e restrições ambientais, identificação e definição de público-alvo, mercado e produto, desenvolvimento de infra-estrutura de apoio ao ecoturismo, zoneamento turístico ambiental e plano de gestão e implantação de centros de interpretação ambiental e de informações turísticas - a equipe multidisciplinar responsável pelo projeto propõe uma matriz de avaliação que apresenta importantes indicadores para este estudo, detalhada a seguir.

Segundo a publicação que apresenta tal metodologia, "trata-se de uma ferramenta de fácil aplicação, que pode ser operada por equipes locais sem maiores 
treinamentos ou formação técnica específica" (MAGALHÃES, 2001, p. 96) - o que, embora pareça atender aos objetivos práticos da referida publicação, não deixa de ser preocupante sob o ponto de vista da (desprezada) capacidade técnica dos avaliadores. $\mathrm{O}$ autor diz ainda que

A matriz de avaliação proposta procura retratar as diversas realidades que compõem um determinado cenário, indicando como as ações que possam vir a ocorrer irão se refletir em todo o conjunto, ou em suas partes. Pode ser aplicada mais de uma vez, na medida em que ações propostas forem se concretizando, de modo a monitorar a evolução do pólo, registrando a situação em diferentes momentos.

Considerando que o pólo é composto por elementos intrinsecamente relacionados, a proposta é atribuir a cada elemento um peso relativo, de tal maneira que se possa obter uma interpretação qualitativa, expressa graficamente, das condições daquele lugar e perceber quais os tipos de ações que devem ser implementadas para promover o seu desenvolvimento. A matriz, portanto, pode ser aplicada nos diferentes elementos territoriais componentes do pólo ecoturístico e os dados das avaliações parciais consolidados em uma matriz única para todo o pólo (MAGALHÃES, 2001, p. 96).

Para fins da avaliação proposta, foram estabelecidos os seguintes elementos: atrativos ecoturísticos, visitação, infra-estrutura de apoio ao ecoturismo, serviços de apoio ao ecoturista, áreas protegidas e políticas públicas voltadas para o desenvolvimento turístico-ambiental da região.

A partir desta avaliação, seria possível observar as necessidades da localidade em termos de expansão do núcleo urbano, de investimentos em infra-estrutura e equipamentos públicos, a ocorrência de visitação e as características dos visitantes e dos atrativos e a existência e a eficácia de políticas públicas para a região. De acordo com Magalhães (2001, p. 96), 
A sistematização dessas informações através de uma matriz gráfica, facilita a compreensão imediata do conjunto, refletindo realidades locais e temáticas diversas, além de possibilitar o contato integrado com os fatores determinantes na problemática do pólo ecoturístico.

Acredita-se que este modelo, aparentemente singelo, possa contribuir na direção correta do planejamento, como um instrumento auxiliar na formatação de ações e posturas que venham a responder às carências e aos problemas identificados.

Para cada um dos itens de matriz de avaliação, deve-se estabelecer notas, em números inteiros, de zero a três (conforme quadro a seguir), sendo que zero significa inexistência do fator considerado e três, a condição de excelência máxima do quesito, tendo-se em mente, ainda, que se parte do princípio que os fatores com baixa pontuação podem ser melhorados e de que a importância de cada quesito é relativa a cada caso e, portanto, deve ser ponderada cuidadosamente pelo grupo gestor local envolvido no processo. Além da atribuição da nota, devese, também, redigir uma justificativa para tal nota, de forma a evitar-se uma avaliação puramente quantitativa.

\begin{tabular}{|c|c|c|c|}
\hline Elementos de Avaliação & Fatores & Notas & Condições \\
\hline \multirow{8}{*}{ Atrativos } & \multirow{4}{*}{ Características } & 0 & Inexistentes \\
\hline & & 1 & Comuns \\
\hline & & 2 & Significativos \\
\hline & & 3 & Excepcionais \\
\hline & \multirow{4}{*}{ Condições para visitação } & 0 & Inexistentes \\
\hline & & 1 & Precárias \\
\hline & & 2 & Inadequadas \\
\hline & & 3 & Adequadas \\
\hline \multirow[t]{7}{*}{ Visitação } & \multirow{4}{*}{ Quantidade } & 0 & Inexistente \\
\hline & & 1 & Excessiva \\
\hline & & 2 & Com potencial \\
\hline & & 3 & Adequada \\
\hline & \multirow[b]{3}{*}{ Origem da demanda } & 0 & Inexistente \\
\hline & & 1 & Local \\
\hline & & 2 & Regional/local \\
\hline
\end{tabular}




\begin{tabular}{|c|c|c|c|}
\hline & & 3 & $\begin{array}{c}\text { Regional/local/ } \\
\text { internacional }\end{array}$ \\
\hline & \multirow{4}{*}{ Sazonalidade } & 0 & Inexistente \\
\hline & & 1 & Esporádica \\
\hline & & 2 & Por temporada \\
\hline & & 3 & Ano inteiro \\
\hline \multirow{12}{*}{ Infra-estrutura } & \multirow{4}{*}{ Acessibilidade e circulação } & 0 & Inexistente \\
\hline & & 1 & Precária \\
\hline & & 2 & Inadequada \\
\hline & & 3 & Adequada \\
\hline & \multirow{4}{*}{ Infra-estrutura urbana } & 0 & Inexistente \\
\hline & & 1 & Precária \\
\hline & & 2 & Inadequada \\
\hline & & 3 & Adequada \\
\hline & \multirow{4}{*}{ Serviços urbanos } & 0 & Inexistentes \\
\hline & & 1 & Precários \\
\hline & & 2 & Inadequados \\
\hline & & 3 & Adequados \\
\hline \multirow{12}{*}{ Serviços } & \multirow{4}{*}{ Meios de hospedagem } & 0 & Inexistentes \\
\hline & & 1 & Precários \\
\hline & & 2 & Inadequados \\
\hline & & 3 & Adequados \\
\hline & \multirow{4}{*}{ Meios de alimentação } & 0 & Inexistentes \\
\hline & & 1 & Precários \\
\hline & & 2 & Inadequados \\
\hline & & 3 & Adequados \\
\hline & \multirow{4}{*}{ Serviços ecoturísticos } & 0 & Inexistentes \\
\hline & & 1 & Precários \\
\hline & & 2 & Inadequados \\
\hline & & 3 & Adequados \\
\hline \multirow{4}{*}{\multicolumn{2}{|c|}{ Áreas protegidas }} & 0 & Inexistentes \\
\hline & & 1 & Não regularizadas \\
\hline & & 2 & Em processo \\
\hline & & 3 & Regularizadas \\
\hline \multirow[t]{4}{*}{ Políticas públicas ${ }^{15}$} & \multirow{4}{*}{ Existência } & 0 & Inexistentes \\
\hline & & 1 & Incipientes \\
\hline & & 2 & Em processo \\
\hline & & 3 & Consolidadas \\
\hline
\end{tabular}




\begin{tabular}{|l|c|c|c|}
\hline & 0 & Inexistentes \\
\cline { 3 - 4 } & $\begin{array}{c}\text { Eficácia (reversão em } \\
\text { benefícios para as } \\
\text { comunidades locais) }\end{array}$ & 2 & Insignificantes \\
\cline { 2 - 3 } & 3 & Irregulares \\
\cline { 2 - 3 } & & Significativos \\
\hline
\end{tabular}

Quadro 3 - Composição da Matriz de Avaliação do Projeto Pólos de Desenvolvimento de Ecoturismo no Brasil

Fonte: adaptado de MAGALHÃES, 2001, p. 98-100.

As avaliações finais dos quesitos atrativos e visitação devem ser feitas a partir das médias ponderadas dos fatores ${ }^{16}$. Maiores informações sobre as reflexões pertinentes à atribuição das notas podem ser encontradas na publicação original, todavia, cabem aqui alguns esclarecimentos e questionamentos adicionais:

- a quantidade da visitação refere-se à estimativa de fluxo de visitantes no pólo em relação à sua capacidade de carga - o que pressupõe a necessidade da existência de tais limites delimitados, e bastante questionáveis atualmente, face às dificuldades de fixação e implantação destes limites e às modernas técnicas de monitoramento e avaliação da visitação que, gradualmente, vão substituindo o conceito tradicional de capacidade de carga;

- será que a quantidade excessiva de visitantes (equivalente à nota 1 no mesmo quesito supra) não pode ser tão (ou mais) prejudicial que a ausência de visitação? Assim, estará de acordo tal sistema de pontuação para este quesito?;

- como definir clara e objetivamente o que se deve entender por "quantidade adequada" de visitantes?

\footnotetext{
${ }^{16}$ Embora não seja mencionado, acredita-se que mesmo procedimento deva ser aplicado aos itens infra-estrutura, serviços e políticas públicas, compostos por dois ou mais fatores de avaliação.
} 
A fim de facilitar a compreensão dos leitores, a publicação apresenta um estudo de caso de implantação de um pólo ecoturístico por meio da representação teórica de uma área abrangendo quatro municípios, descrita sob a perspectiva dos componentes da avaliação ora apresentada, de modo a possibilitar uma simulação do processo.

A partir desta simulação, chega-se a um diagnóstico da situação atual do pólo (representado graficamente de acordo com a matriz proposta), a recomendações e propostas de ações para a área e a uma nova matriz resultante da consideração das possibilidades reais de execução das ações, que, consequentemente, apresentará outra configuração (diferente da inicial), "[...] evidenciando o potencial da região e sua identificação como pólo ecoturístico" (MAGALHÃES, 2001, p. 102).

A mesma publicação traz, ainda, um quadro de valoração turística, por meio do qual "uma outra análise das condições da região e da identificação de seu potencial de desenvolvimento ecoturístico pode ser feita [...]" (MAGALHÃES, 2001, p. 103).

Neste quadro, apresentado a seguir, são listados os itens considerados mais importantes e a eles atribuídos valores ou notas maiores do que as do exemplo anterior.

\begin{tabular}{|l|c|l|c|}
\hline \multicolumn{1}{|c|}{ Elementos } & Real & \multicolumn{2}{c|}{ Justificativa } \\
\hline ATRATIVOS & +1 & Faltam equipamentos e guias & +5 \\
\hline Rios & +1 & Faltam acesso e informações & +4 \\
\hline Cachoeiras & 0 & Inexploradas & +3 \\
\hline Cavernas & +2 & Poucas informações & +3 \\
\hline Fauna
\end{tabular}




\begin{tabular}{|c|c|c|c|}
\hline Vegetação & +1 & Poucas informações & +3 \\
\hline Construções históricas & -2 & Abandonadas & +2 \\
\hline Sítios arqueológicos & -2 & Inexplorados & +2 \\
\hline Festas populares & 0 & Poucas informações & +2 \\
\hline Culinária & +1 & Poucas informações & +3 \\
\hline Artesanato & 0 & Poucas informações & +2 \\
\hline TOTAL PARCIAL & +2 & & +29 \\
\hline \multicolumn{4}{|l|}{ ÁREAS PROTEGIDAS } \\
\hline Parques nacionais & 0 & Inexistentes & 0 \\
\hline Parques estaduais & 0 & Criação de um Parque do Cerrado & +3 \\
\hline Parques municipais & 0 & Criação de um centro de visitação & +3 \\
\hline APAs & +1 & Pouco significativa & +1 \\
\hline RPPNs & 0 & Áreas particulares adequadas & +2 \\
\hline TOTAL PARCIAL & +1 & & +9 \\
\hline \multicolumn{4}{|l|}{ PÚBLICO ${ }^{17}$} \\
\hline Ecoturista típico & +1 & Poucas informações & +4 \\
\hline Estudantes & +1 & Poucas informações & +4 \\
\hline Especialistas & 0 & Poucas informações & +4 \\
\hline Esportistas & +1 & Poucas informações & +4 \\
\hline TOTAL PARCIAL & +3 & & +16 \\
\hline \multicolumn{4}{|l|}{ INFRA-ESTRUTURA } \\
\hline Hospedagem & 0 & Inexistência de hotéis e pousadas & +3 \\
\hline Alimentação & +1 & Somente um bar e uma lanchonete & +4 \\
\hline Acesso & +2 & Estradas secundárias ruins & +5 \\
\hline Comunicação & -1 & Faltam telefones & +3 \\
\hline Saneamento & -1 & Precário & +4 \\
\hline Saúde & -2 & Ausência de hospital & +4 \\
\hline TOTAL PARCIAL & -1 & & +23 \\
\hline \multicolumn{4}{|l|}{ SERVIÇOS } \\
\hline Agências de turismo & -1 & Não existem & +4 \\
\hline Guias & -2 & Não existem & +5 \\
\hline Informação & -1 & Muito precária & +5 \\
\hline TOTAL PARCIAL & -4 & & +14 \\
\hline \multicolumn{4}{|l|}{ PROGRAMAS } \\
\hline PNMT & +1 & Incipiente & +4 \\
\hline Investimentos & 0 & Não existem & +4 \\
\hline Associativismo & +1 & Incipiente & +5 \\
\hline TOTAL PARCIAL & +2 & & +13 \\
\hline TOTAL GERAL & +3 & & +104 \\
\hline
\end{tabular}

Quadro 4 - Valoração Ecoturística Fonte: MAGALHÃES, 2001, p. 103

As notas acima atribuídas, que variam entre +5 e -5 , baseiam-se em um estudo de caso e indicam a situação real de cada fator considerado, seguida da justificativa

17 A mesma publicação apresenta, mais adiante, outro quadro de valoração que relaciona os atrativos e serviços disponíveis em um dada localidade com os vários tipos de visitantes, dentro os quais incluem-se os mencionados no quadro (MAGALHÃES, 2001, p.106). 
de tal pontuação, e a situação potencial, que poderá ser alcançada com a implementação das ações propostas.

A diferença entre os totais (reais e potenciais) explicita as possibilidades de crescimento e as áreas que deverão receber uma atenção maior para que se atinja um maior nível de desenvolvimento. Magalhães (2001, p. 103) aponta que

Este é um exemplo simples de utilização de um quadro de valoração ecoturística. Em uma situação verdadeira de implantação de um pólo, muitos outros fatores poderão ser considerados. A sua relação deverá ser estabelecida pelo grupo gestor, após cuidadoso levantamento, com a participação dos elementos da comunidade interessados e com a colaboração de consultores especializados em questões turísticas e ambientais.

Os métodos ora apresentados, embora possam apresentar algumas restrições quanto ao rigor científico em sua aplicação - em decorrência das razões já mencionadas anteriormente e da subjetividade e da arbitrariedade com que as notas são atribuídas (sobretudo no último quadro apresentado) - constituem-se em interessante tentativa de mensuração do potencial turístico e, certamente, serão úteis para a definição do método apresentado nesta tese.

\subsection{A Classificação e a Avaliação dos Municípios Turísticos de Boullón}

A fim de propor uma classificação dos municípios turísticos, Boullón (1995, p. 3356) utiliza-se de diversos critérios por meio dos quais chega a diferentes classificações: 
- classificação a partir da demanda: baseada no número de visitantes simultâneos que uma localidade recebe, ela pode ser classificada em cinco níveis e, segundo a origem do mercado emissor, pode-se classificar os centros turísticos em interno (local, zonal ou nacional) e receptivo (fronteiriço, limítrofe ou não limítrofe);

- classificação em relação ao funcionamento: resulta na classificação de cinco formas de funcionamento (centros de distribuição, de estadia, de escala, de excursão ou centro recreativo);

- classificação em relação à oferta de equipamentos: valendo-se da análise dos equipamentos turísticos (alojamento, alimentação, entretenimento e outros serviços), o autor propõe um sistema de pontuação que permite a sua classificação.

Boullón afirma que, dos quatro indicadores supramencionados para expressar a importância da planta turística de uma área, o alojamento é o mais importante. Este subdivide-se em hoteleiro (hotéis, motéis, pousadas, pensões etc.), parahoteleiro (apart-hotéis, albergues, campings, áreas para trailers etc.) e extrahoteleiro (apartamentos em condomínios e casas individuais, por exemplo).

Quanto aos equipamentos hoteleiros, deve-se contabilizar as habitações disponíveis e agrupá-las nas cinco categorias disponíveis (uma a cinco estrelas) ${ }^{18}$, outorgando-se uma pontuação distinta a cada hierarquia.

\footnotetext{
${ }^{18}$ A categorização de empreendimentos hoteleiros em estrelas, variáveis de uma a cinco e relativas a estabelecimentos mais simples (uma estrela) a mais luxuosos (cinco estrelas) obedece a um critério que durante muito tempo foi adotado por muitos países, entre eles a Argentina, país natal do autor citado. Atualmente, esta classificação não é oficial, mas pela extensão de seu uso, no espaço e no tempo, carrega um significado técnico amplamente compreendido por profissionais do setor turístico.
} 
Para avaliar os alojamentos parahoteleiros e extra-hoteleiros, deve-se inventariar, segundo Boullón (1995, p. 44), todos os equipamentos reunidos nestas categorias e calcular a capacidade total de cada um - em ambos os casos, depois de se obter a capacidade total de hospedagem (em número de pessoas), deve-se dividir este número por dois para equiparar o resultado ao padrão encontrado nos alojamentos hoteleiros (que costumam disponibilizar quartos duplos). No quadro a seguir são demonstradas as condições mencionadas anteriormente e se estabelecem as pontuações para as diferentes categorias ${ }^{19}$, aplicadas para cada 100 unidades habitacionais:

\begin{tabular}{|c|c|c|}
\hline Tipos & Hierarquias dos Serviços & $\begin{array}{c}\text { Pontuações (para cada 100 } \\
\text { Unidades Habitacionais) }\end{array}$ \\
\hline \multirow{4}{*}{ Hoteleiro } & 5 estrelas & 300 \\
\cline { 2 - 3 } & 4 estrelas & 150 \\
\cline { 2 - 3 } & 3 estrelas & 80 \\
\cline { 2 - 3 } & 2 estrelas & 40 \\
\hline Parahoteleiro & 1 estrela & 20 \\
\hline Extra-hoteleiro & - & 40 \\
\hline
\end{tabular}

Quadro 5 - Avaliação da Oferta de Alojamento

Fonte: BOULLÓN, 1995, p. 44

Os equipamentos de alimentação, por sua vez, devem ser hierarquizados sem se levar em conta a que tipo pertencem, dada a diversidade de opções (restaurantes, cafeterias, quiosques, etc.) - tendo-se em vista, inclusive, que é mais importante

\footnotetext{
${ }^{19}$ Segundo o autor, "Os alojamentos parahoteleiros e extra-hoteleiros tem respectivamente a mesma pontuação que os hotéis de uma e duas estrelas, porque do ponto de vista de seu rendimento econômico, estimado a partir do número de empregos que geram, são aproximadamente equivalentes a estes tipos, ainda que por vezes a qualidade dos edifícios de alguns apartamentos, apart-hotéis, casa ou cabanas supere a dos alojamentos hoteleiros de uma ou duas estrelas" (BOULLÓN, 1995, p.44).
} 
que se conheça a qualidade da comida e do serviço que a tipologia do estabelecimento.

Para a hierarquização de tais equipamentos, Boullón (1995, p. 45) prefere utilizarse de uma escala de apenas três valores (ver quadro a seguir), visto que a escala usada para a hierarquização dos equipamentos hoteleiros (com cinco opções), além de incluir opções para aquilo que se está avaliando, pode levar a uma avaliação se não arbitrária, um tanto subjetiva, visto que as diferenças entre um nível e outro podem ser muito sutis.

\begin{tabular}{|c|c|c|}
\hline Hierarquias dos Serviços & Equivalentes em Estrelas & Pontuações \\
\hline A & 5 & 100 \\
\hline B & 4 & 50 \\
\hline C & 3,2 e 1 & 20 \\
\hline
\end{tabular}

Quadro 6 - Avaliação da Oferta de Alimentação

Fonte: BOULLÓN, 1995, p. 45

Para a oferta de equipamentos de entretenimento, Boullón (1995, p. 45-46) propõe a seguinte classificação:

\begin{tabular}{|c|c|}
\hline Tipos & Pontuações \\
\hline Parques temáticos & 500 \\
\hline $\begin{array}{c}\text { Cassinos e estabelecimentos com jogos de } \\
\text { azar }\end{array}$ & 300 \\
\hline Centros noturnos & 50 \\
\hline Outros espetáculos públicos & 50 \\
\hline
\end{tabular}

Quadro 7 - Avaliação da Oferta de Entretenimentos Fonte: BOULLÓN, 1995, p. 46

A última categoria compreende uma ampla gama de outros serviços, que inclui agências de viagens, informação, guias, comércio, câmbio de moeda, espaços 
para congressos e convenções, transportes turísticos, estacionamentos, dentre outros.

A fim de propiciar uma avaliação mais correta desta categoria e evitar distorções nos resultados, Boullón (1995, p. 46-47) propõe a exclusão de alguns destes serviços do rol de itens a serem avaliados (conforme quadro a seguir) e recomenda:

- quanto às agências de viagens, somente devem ser consideradas aquelas que prestam serviços receptivos;

- deve-se separar os espaços para congressos e convenções instalados em hotéis, clubes ou quaisquer outros tipos de instituições que comercializem outros serviços, dos centros de congressos e convenções ,e em ambos os casos, deve-se considerar a capacidade de cada elemento inventariado;

- quanto aos transportes turísticos, considerar apenas as empresas dedicadas à locação de automóveis, desconsiderando-se os táxis, os serviços prestados por agências de viagens de ação local ou por algumas pequenas empresas muito pouco estruturadas que oferecem serviços improvisados nos períodos de maior afluência de turistas;

- da planta comercial, devem ser selecionados os estabelecimentos que efetivamente atraiam a atenção dos turistas. 


\begin{tabular}{|c|c|}
\hline Tipos & Pontuações \\
\hline $\begin{array}{c}\text { Centros de convenções (capacidade superior } \\
\text { a 1.000 pessoas) }\end{array}$ & 500 \\
\hline $\begin{array}{c}\text { Centros de convenções (capacidade inferior } \\
\text { a 1.000 pessoas) }\end{array}$ & 300 \\
\hline $\begin{array}{c}\text { Congressos e convenções em hotéis } \\
\text { (capacidade superior a 300 pessoas) }\end{array}$ & 100 \\
\hline $\begin{array}{c}\text { Congressos e convenções em hotéis } \\
\text { (capacidade de100 a 300 pessoas) }\end{array}$ & 50 \\
\hline Locadoras de automóveis & 80 \\
\hline Agências de turismo de ação local & 40 \\
\hline Comércio de interesse turístico & 10 \\
\hline
\end{tabular}

Quadro 8 - Avaliação da Oferta de Outros Serviços

Fonte: BOULLÓN, 1995, p. 47

Além dos equipamentos turísticos, Boullón (1995, p. 82) lembra que a de acordo com as metodologias de inventário da oferta turística, deve-se considerar, ainda, os atrativos turísticos e as instalações, que compõem a chamada planta turística.

Quanto aos atrativos, o autor observa que a maior dificuldade reside no procedimento de avaliação, devido ao fato que "[...] em toda cidade se observa uma tendência a supermestimar seu patrimônio", e que, "a fim de evitar as deformações a que pode conduzir esta tendência, deve-se aplicar os critérios de avaliação de um atrativo em relação a sua capacidade para atrair os diferentes tipos de mercado" (BOULLÓN, 1995, p. 82).

Para simplificar esta tarefa de avaliação, segundo o autor, é aconselhável resumir em quatro os seis tipos de mercado anteriormente mencionados (classificação a partir da demanda segundo a origem do mercado emissor), outorgando a cada um a pontuação que consta do quadro a seguir: 


\begin{tabular}{|c|c|c|}
\hline Hierarquias & Valores & Tipos de Mercados \\
\hline IV & 3.000 & Receptivo não limítrofe e limítrofe \\
\hline III & 200 & Receptivo fronteiriço e interno nacional \\
\hline II & 10 & Interno zonal \\
\hline I & 1 & Interno local \\
\hline
\end{tabular}

Quadro 9 - Avaliação dos Atrativos Turísticos

Fonte: BOULLÓN, 1995, p. 82

Por fim, Boullón (1995, p. 43) observa que as instalações (de água e praia, de montanha e gerais) são muito difíceis de se avaliar, pois o número de tipos que as compõem é muito elevado e porque reúnem elementos muito diversos.

Todavia, destaca que tais aspectos não devem ser empecilhos "[...] para que se registrem com igual critério sistemático que o aplicado aos atrativos e aos equipamentos, no que toca à descrição das características técnicas que as definem" (BOULLÓN, 1995, p. 82). E afirma (p. 48):

Depois de avaliar a potencialidade de um centro, em função da hierarquia de seus atrativos, entra em jogo o valor da planta turística, que se obtém mediante a soma da pontuação obtida por cada um dos quatro indicadores que integram o índice da oferta. Isto é correto, já que a planta turística é um atrativo em si mesma, o que pode pesar a favor ou contra a decisão de visitar um centro turístico.

O autor conclui que estes vários índices tratam de expressar de modo mais objetivo possível um determinado estado de coisas em cada centro ou município turístico, porém nenhum deles deve ser considerado individualmente já que, na prática, o turista os examina e considera em conjunto antes de efetuar sua seleção. 
Tampouco deve se esquecer que esta seleção depende em boa medida das preferências do futuro turista por um ou outro tipo de atrativo - por exemplo, mar ou montanha -, e que dentro de cada uma destas opções a decisão final será influenciada pelas hierarquias que alcança o grupo de atrativos complementares.

\section{$[\ldots]$}

A incorporação do valor da oferta turística permite ordenar em uma escala de importância todos os centros de um país, uma região ou uma província que foram previamente classificados pela origem do mercado e por seu funcionamento. Esta informação, mais tarde, será útil para tomar decisões a respeito dos programas de promoção e dos planos gerais de desenvolvimento do espaço turístico, e planos particulares de cada município turístico.

Isto posto, não é difícil concluir que embora Boullón forneça alguns caminhos para a identificação do potencial turístico de localidades receptoras, com ponderações bastante pertinentes no sentido de facilitar tal avaliação, a ausência de indicadores para a avaliação do que ele chama de instalações turísticas e a consideração de alguns fatores agrupados de forma excessivamente macro (como é o caso dos atrativos), comprometem parcialmente sua proposta ao torná-la um tanto simplista.

\subsection{0 Índice de Atratividade Turística de Gearing, Swart e Var}

Fagliari e Almeida (2004, p. 40-41), em seu trabalho de conclusão de curso de especialização, apresentam sinteticamente o método desenvolvido por Gearing, Swart e Var em meados da década de 1970 que resulta no Índice de Atratividade Turística ou Tourist Attraction Index (TAl).

Segundo as autoras, trata-se de um método indireto de preferência dos usuários que mede a atratividade de um destino turístico a partir de uma avaliação sistemática padronizada. Dizem FAGLIARI e ALMEIDA (2004, p. 40) que 
Em uma primeira etapa da pesquisa, o procedimento do TAI consiste basicamente em uma pesquisa com especialistas, na qual os respondentes devem dar pesos para diversos atributos do atrativo turístico, de forma a determinar a importância de cada um deles para a atividade turística. Após a conclusão desta etapa, os especialistas devem avaliar um determinado número de destinos turísticos, baseando-se nos atributos pré-definidos. Durante essa avaliação é utilizada uma escala numérica que permite quantificar os atributos analisados. Como cada um deles possui um peso específico, o método foi desenvolvido de uma forma tal que a simples soma dos atributos consiste em uma estimativa da atratividade total do destino.

Zopf (2003 apud FAGLIARI e ALMEIDA, 2004, p. 40), ao analisar o TAI, destaca que o método depende da escolha e da capacitação dos especialistas mais adequados para participação no processo de identificação dos atributos relevantes dos atrativos.

Fagliari e Almeida (2004, p. 40-41) definem o TAl como um método interessante para a medição da atratividade de destinos turísticos, que se caracteriza pela simplicidade e pela maleabilidade em termos de tipos de destinos e da facilidade de adaptação ao uso para avaliação de atrativos turísticos.

Todavia, as autoras lamentam a falta de mais informações sobre o método, que permitiriam uma análise mais acurada do mesmo. Comentam que

A falta de dados não permite compreender a definição e as formas de uso da escala numérica citada. Além disso, dá a entender que os determinantes e seus parâmetros, os carros-chefe do método, são totalmente definidos para cada caso específico. Nesse caso, parece haver enorme responsabilidade por parte dos especialistas convidados a participar da aplicação da metodologia, pois, caso isso não seja feito da forma adequada, a pesquisa pode perder sua validade (FAGLIARI e ALMEIDA, 2004, p. 41).

Evidentemente, a escassez de informações sobre o método compromete sua avaliação, mas assim como outros métodos descritos nesta tese, depende-se da 
participação de especialistas para a obtenção de resultados mais confiáveis do ponto de vista técnico.

\subsection{A Análise dos Fatores de Produtividade para a Localização de Projetos Turísticos de Cárdenas Tabares}

Cárdenas Tabares (1994, p. 7-11), em sua obra sobre projetos turísticos, defende que o estudo do mercado e da localização são os aspectos que exigem mais atenção, pois deles depende a rentabilidade futura do projeto e, em função desta afirmação, ocupa-se, em grande parte, a tratar do segundo aspecto, propondo a análise dos fatores decisivos, importantes e desejáveis para a localização de projetos turísticos:

- fatores decisivos:

- existência de vias de comunicação;

- segurança ao conduzir;

- intensidade do trânsito;

- distância que separa os centros urbanos maiores e tempo requerido para chegar a eles;

- disponibilidade de água;

- disponibilidade de energia elétrica;

- disponibilidade de comunicações telefônicas;

- disponibilidade de terrenos;

- atrativos turísticos;

- qualidade do desenvolvimento circunvizinho;

- condições sociais; 
- condições de salubridade;

- fatores importantes:

- proximidade das vias principais;

- custo do terreno;

- condições do subsolo;

- topografia;

- fatores desejáveis:

- disponibilidade de materiais e mão-de-obra;

- condições meteorológicas;

- facilidade de abastecimento de água

Segundo o autor, os fatores decisivos são assim chamados porque sem a existência de algum destes itens, a produtividade do projeto seria nula ou talvez não existisse (CÁRDENAS TABARES, 1994, p. 11) - razão pela qual correspondem a $60 \%$ dos fatores de rentabilidade segundo a localização dos projetos turísticos. Os fatores importantes e desejáveis correspondem a 30\% e a 10\%, respectivamente (CÁRDENAS TABARES, 1994, p. 12).

Ao propor uma avaliação destes fatores, o autor estabelece, a partir das porcentagens (ou pesos) acima, um máximo de pontos para cada grupo de fatores: os fatores decisivos são avaliados com um máximo de 60 pontos; os importantes, com um máximo de 25 pontos e os desejáveis, com um máximo de 15 pontos.

Os limites para efetuar a avaliação individual de cada fator vão de zero a cinco pontos, da seguinte forma: 


\begin{tabular}{|c|c|}
\hline Significados dos Fatores & Pontos \\
\hline Inexistente & 0 \\
\hline Pobre & 1 \\
\hline Regular & 2 \\
\hline Bom & 3 \\
\hline Excelente & 4 \\
\hline Ótimo & 5 \\
\hline
\end{tabular}

Quadro 10 - Pontuação para Avaliação dos Fatores para Localização de Projetos Turísticos Fonte: CÁRDENAS TABARES, 1994, p. 25

Para o autor, ao somar-se os pontos dos fatores, poder-se-ão estabelecer as comparações quantitativas entre as diferentes possibilidades que estão sendo estudadas. A qualificação final é obtida com base nos seguintes critérios:

\begin{tabular}{|c|c|}
\hline Localização & Pontos \\
\hline Descartável & De 0 a 15 \\
\hline Ruim & De 16 a 35 \\
\hline Regular & De 36 a 55 \\
\hline Boa & De 56 a 75 \\
\hline Excelente & De 76 a 95 \\
\hline Ótima & De 96 a 100 \\
\hline
\end{tabular}

Quadro 11 - Pontuação para Classificação da Localização de Projetos Turísticos Fonte: CÁRDENAS TABARES, 1994, p. 25

Ainda segundo Cárdenas Tabares (1994, p. 25), o reconhecimento da pontuação deve ser efetuado em nível microeconômico (do projeto específico) por zonas, áreas, complexos, centros, núcleos, conjuntos e corredores de traslado e de estadia, segundo a teoria do espaço turístico de Boullón.

A fim de facilitar a atribuição da pontuação supramencionada às variáveis que integram cada um dos fatores, Cárdenas Tabares (1994, p. 32-35) oferece o seguinte referencial: 


\begin{tabular}{|c|c|c|}
\hline & Fatores & Pontos \\
\hline \multicolumn{3}{|c|}{ FATORES DECISIVOS } \\
\hline \multirow{6}{*}{$\begin{array}{l}\text { Existência de vias } \\
\text { de comunicação }\end{array}$} & Localização sobre caminhos vicinais & 0 \\
\hline & Localização sobre estradas sem continuidade & 1 \\
\hline & $\begin{array}{c}\text { Localização sobre estradas contínuas, mas que não } \\
\text { unem diretamente pólos econômicos }\end{array}$ & 2 \\
\hline & $\begin{array}{c}\text { Localização sobre estradas sem continuidade, mas que } \\
\text { unem pólos econômicos }\end{array}$ & 3 \\
\hline & $\begin{array}{l}\text { Localização sobre estradas contínuas que unem vários } \\
\text { pólos econômicos }\end{array}$ & 4 \\
\hline & Localização sobre estradas de ligação internacional & 5 \\
\hline \multirow{12}{*}{$\begin{array}{l}\text { Segurança ao } \\
\text { conduzir }\end{array}$} & $\begin{array}{l}\text { Vias com traçado e superfície defeituosos, ou } \\
\text { montanhosas }\end{array}$ & 0 \\
\hline & $\begin{array}{l}\text { Vias com traçados defeituosos, superfície normal, } \\
\text { montanhosas }\end{array}$ & 1 \\
\hline & $\begin{array}{l}\text { Vias com traçado normal, superfícies defeituosas, } \\
\text { montanhosas }\end{array}$ & 1 \\
\hline & $\begin{array}{l}\text { Vias com traçado e superfície defeituosos, topografia } \\
\text { variada }\end{array}$ & 1 \\
\hline & $\begin{array}{c}\text { Vias com traçado defeituoso, superfície normal, } \\
\text { topografia variada }\end{array}$ & 2 \\
\hline & $\begin{array}{c}\text { Vias com traçado normal, superfície defeituosa, } \\
\text { topografia variada }\end{array}$ & 1 \\
\hline & Vias com traçado e superfície defeituosos, planas & 1 \\
\hline & Vias com traçado defeituoso, superfície normal, planas & 2 \\
\hline & Vias com traçado normal, superfície defeituosa, planas & 2 \\
\hline & Vias com traçado e superfície normais, montanhosas & 3 \\
\hline & Vias com traçado e superfície normais, topografia variada & 4 \\
\hline & Vias com traçado e superfície normais, planas & 5 \\
\hline \multirow{4}{*}{$\begin{array}{l}\text { Intensidade de } \\
\text { trânsito }\end{array}$} & Vias com alto volume de trânsito diário & 5 \\
\hline & Vias com médio volume de trânsito diário & 3 \\
\hline & Vias com baixo volume de trânsito diário & 1 \\
\hline & Vias com alto volume de trânsito durante o fim de semana & 4 \\
\hline \multirow{6}{*}{$\begin{array}{l}\text { Distância-tempo } \\
\text { de centros } \\
\text { urbanos maiores } \\
\text { (a sítios } \\
\text { potenciais) }\end{array}$} & Maiores de três horas & 0 \\
\hline & Entre duas e três horas & 1 \\
\hline & A 90 minutos & 2 \\
\hline & A 60 minutos & 3 \\
\hline & A 45 minutos & 4 \\
\hline & A 35 minutos & 5 \\
\hline \multirow{3}{*}{$\begin{array}{l}\text { Disponibilidade de } \\
\text { água }\end{array}$} & De aqueduto com projeto & 5 \\
\hline & De aqueduto incompleto & 3 \\
\hline & De poço, rio ou lago, de difícil tratamento & 0 \\
\hline
\end{tabular}




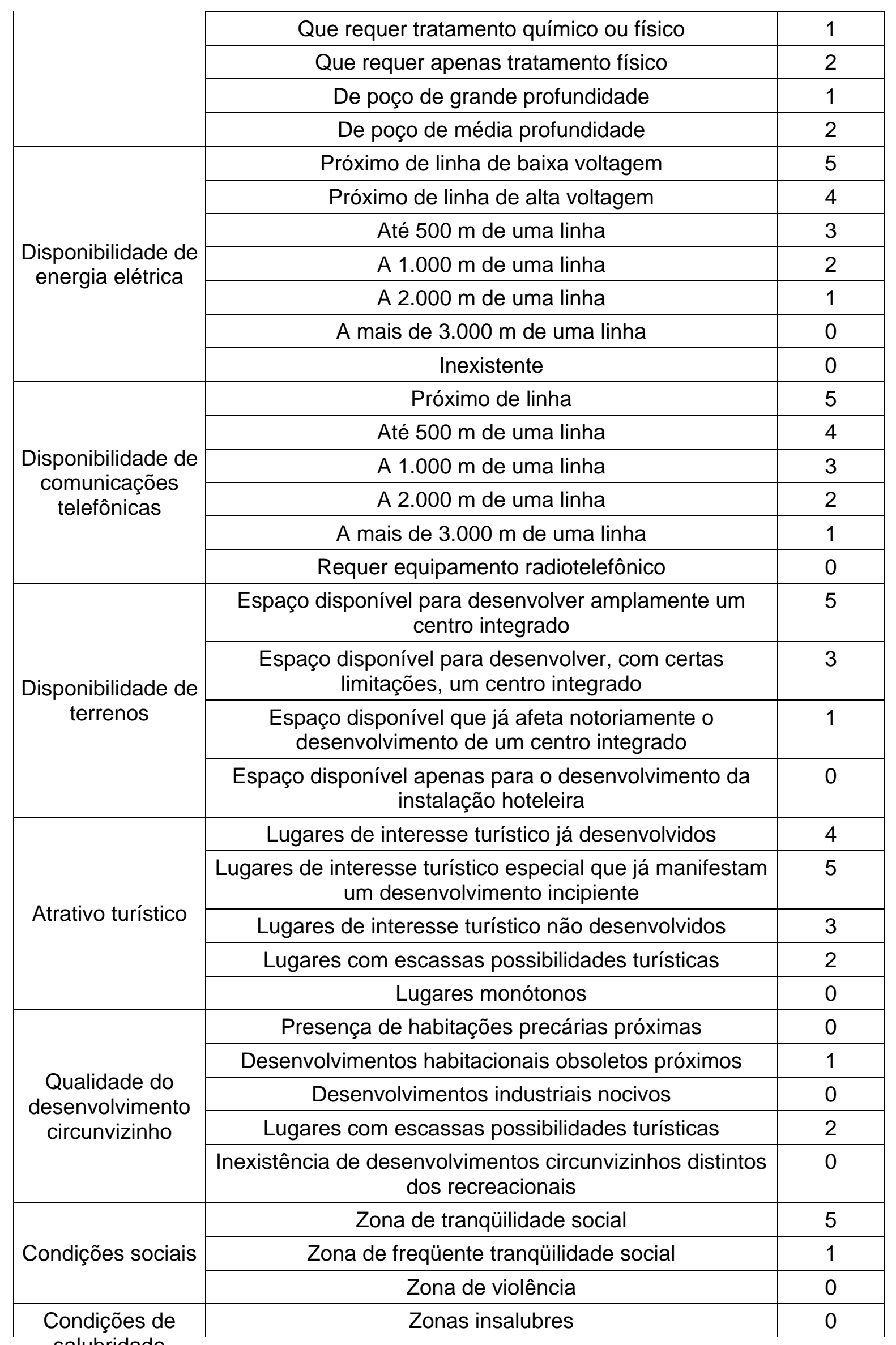

salubridade 


\begin{tabular}{|c|c|c|}
\hline & $\begin{array}{c}\text { Zonas de acentuada umidade e temperatura alta, sujeitas } \\
\text { a desenvolvimento de pragas } \\
\end{array}$ & 1 \\
\hline & Zona de clima muito rigoroso & 2 \\
\hline & Zonas de clima médio & 5 \\
\hline \multicolumn{3}{|c|}{ FATORES IMPORTANTES } \\
\hline \multirow{5}{*}{$\begin{array}{l}\text { Proximidade das } \\
\text { vias principais }\end{array}$} & Próximo da via & 5 \\
\hline & Visível a $500 \mathrm{~m}$ & 4 \\
\hline & Visível a $1.000 \mathrm{~m}$ & 3 \\
\hline & Visível a mais de $1.000 \mathrm{~m}$ & 2 \\
\hline & Invisível a qualquer distância & 0 \\
\hline \multirow{6}{*}{ Custo do terreno } & Exorbitante & 0 \\
\hline & Muito alto & 0 \\
\hline & Além do normal & 3 \\
\hline & Baixo & 4 \\
\hline & Cessão gratuita & 5 \\
\hline & Arrendamento por prazo muito longo por entidade oficial & 2 \\
\hline \multirow{4}{*}{$\begin{array}{l}\text { Condições do } \\
\text { subsolo }\end{array}$} & Condições instáveis & 0 \\
\hline & Nível freático muito alto & 1 \\
\hline & Aflorações custosas de serem superadas & 1 \\
\hline & Condições aptas para a construção de edifícios baixos & 5 \\
\hline \multirow{7}{*}{ Topografia } & Declividade até $10 \%$ & 0 \\
\hline & Declividade entre $10 \%$ e $15 \%$ & 4 \\
\hline & Declividade entre $15 \%$ e $20 \%$ & 3 \\
\hline & Declividade entre $20 \%$ e $30 \%$ & 2 \\
\hline & Declividade entre $30 \%$ e $40 \%$ & 1 \\
\hline & Declividade maior que $40 \%$ & 0 \\
\hline & Terrenos demasiadamente planos & 0 \\
\hline \multicolumn{3}{|c|}{ FATORES DESEJÁVEIS } \\
\hline \multirow{5}{*}{$\begin{array}{l}\text { Disponibilidade de } \\
\text { materiais e mão } \\
\text { de obra }\end{array}$} & Existentes em quantidade e boa qualidade & 5 \\
\hline & Existentes em quantidade e qualidade aceitáveis & 4 \\
\hline & Limitados, com custos adicionais normais por transporte & 3 \\
\hline & Escassos, com custos adicionais consideráveis & 1 \\
\hline & Praticamente inexistentes & 0 \\
\hline \multirow{3}{*}{$\begin{array}{l}\text { Condições } \\
\text { meteorológicas }\end{array}$} & Zonas notavelmente nebulosas & 0 \\
\hline & $\begin{array}{l}\text { Zonas de extrema precipitação e notória freqüência de } \\
\text { tormentas elétricas }\end{array}$ & 1 \\
\hline & Normais & 5 \\
\hline \multirow[b]{2}{*}{$\begin{array}{l}\text { Facilidades de } \\
\text { deságües }\end{array}$} & $\begin{array}{l}\text { Deságües por gravidade a servidões que não acarretem } \\
\text { prejuízos ou moléstias }\end{array}$ & 1 \\
\hline & $\begin{array}{l}\text { Deságües por bombeamento a servidões como as } \\
\text { anteriores }\end{array}$ & 1 \\
\hline
\end{tabular}


\begin{tabular}{|c|c|}
\cline { 2 - 3 } & Deságües que requerem tratamento de águas \\
\hline
\end{tabular}

Quadro 12 - Avaliação dos Fatores para Localização de Projetos Turísticos

Fonte: Adaptado de CÁRDENAS TABARES, 1994, p. 32-35

Além dos fatores acima mencionados, Cárdenas Tabares (1994, p. 46-47) recomenda a avaliação dos atrativos turísticos (exame crítico dos atrativos para estabelecer seu interesse turístico sobre bases objetivas e comparáveis) e posterior hierarquização, segundo os critérios abaixo, adaptados da metodologia do Centro Interamericano de Capacitação Turística (CICATUR), da Organização dos Estados Americanos (OEA ${ }^{20}$, que classifica os atrativos turísticos como sendo de:

- hierarquia 5: atrativo excepcional e de grande significado para o mercado turístico internacional, capaz por si só de motivar uma importante corrente (atual ou potencial) de visitantes, quantificada como uma porcentagem do total da demanda do país ou de algum mercado específico;

- hierarquia 4: atrativo com características excepcionais em um país, capaz de motivar uma corrente (atual ou potencial) de visitantes do mercado interno ou externo, mas em menor porcentagem que os da hierarquia 5, seja por si só ou em conjunto com outros atrativos contíguos;

- hierarquia 3: atrativo com alguma característica chamativa, capaz de interessar a visitantes provenientes de longa distância, seja do mercado interno ou externo, que tivessem chegado a esta zona por outras motivações turísticas; ou capaz de motivar correntes turísticas (atuais ou potenciais) locais;

${ }^{20}$ O modelo do CICATUR foi ligeiramente modificado, segundo Tabares (1994, p.47), para adequar-se à avaliação da localização de projetos turísticos anteriormente apresentada. 
- hierarquia 2: atrativos com méritos suficientes para serem considerados importantes para o mercado interno, mas sem condições para o turismo receptivo, e que formam parte do patrimônio turístico;

- hierarquia 1: atrativos sem méritos suficientes para serem considerados nas hierarquias anteriores, mas que igualmente formam parte do patrimônio turístico como elementos que podem ser agregados a outros de maior hierarquia no desenvolvimento e funcionamento de qualquer uma das unidades que integram o espaço turístico;

- hierarquia 0: atrativos cujas qualidades não permitem serem incorporados à hierarquia 1, que é o nível mínimo de hierarquização.

Por fim, o autor salienta que a produtividade turística deve incluir uma dimensão da qualidade em todos seus componentes, já que se a produtividade é incrementada às custas da qualidade, os benefícios tendem a ser muito reduzidos, tendendo, por fim, a reduzirem-se.

Cárdenas Tabares aponta (1994, p. 54-55) que

Isto significa que, quanto ao entorno físico dos projetos deve-se conhecer a qualidade dos atrativos turísticos pelo fato de que são eles o motivo das viagens e a razão do incremento do número de visitantes. Este é o motivo pelo qual devem ser estabelecidos intervalos para determinar a qualidade dos atrativos turísticos inventariados [...].

Utilizando-se dos mesmos intervalos das avaliações anteriormente propostas pelo autor, têm-se o seguinte: 


\begin{tabular}{|c|c|}
\hline Hierarquias & Significados das Hierarquias \\
\hline Atrativos não hierarquizáveis & 0 \\
\hline Atrativos de qualidade pobre & 2 \\
\hline Atrativos de qualidade regular & 3 \\
\hline Atrativos de qualidade boa & 4 \\
\hline Atrativos de qualidade excelente & 5 \\
\hline Atrativos de qualidade ótima & 2 \\
\hline
\end{tabular}

Quadro 13 - Hierarquização da Qualidade dos Atrativos Turísticos

Fonte: CÁRDENAS TABARES, 1994, p. 55

Somando-se os pontos correspondentes às diferentes hierarquias, poder-se-á estabelecer a qualidade dos atrativos existentes no entorno físico dos projetos turísticos, que, por sua vez, também pode ser classificada de acordo com os seguintes critérios:

\begin{tabular}{|c|c|}
\hline Qualidades dos Atrativos & Pontuação Total \\
\hline Descartável & De 0 a 18 \\
\hline Ruim & De 19 a 36 \\
\hline Regular & De 37 a 55 \\
\hline Boa & De 56 a 74 \\
\hline Excelente & De 75 a 94 \\
\hline Ótima & De 95 a 100 \\
\hline
\end{tabular}

Quadro 14 - Hierarquização da Qualidade dos Atrativos Turísticos Fonte: CÁRDENAS TABARES, 1994, p. 55.

Cárdenas Tabares (1994, p. 55).defende que

A partir da qualidade boa, ou seja, de 56 pontos em diante, se pode fomentar o turismo receptivo para obter divisas que tornem mais rentáveis os projetos turísticos. Quando se conta com atrativos nos três últimos intervalos, mediante um adequado plano de marketing, pode-se assegurar êxito na produtividade.

Embora não tenha sido criado com a finalidade de servir ao estudo do potencial turístico, este método revela-se bastante interessante ao considerar importantes elementos da oferta turística e suas possibilidades de avaliação e quantificação. 
Todavia, a ausência de explicação sobre a possibilidade de integração entre os fatores de ponderação para localização de projetos turísticos, a hierarquização e a qualificação dos atrativos apresentam restrições que devem ser contornadas por meio do aperfeiçoamento do método.

\subsection{A Matriz de Avaliação de Atrações Turísticas de Inskeep}

Segundo Inskeep (1991, p. 95), a avaliação por meio do uso de matrizes é normalmente utilizada nas análises de planejamento a fim de se aplicar uma abordagem sistemática e objetiva para a avaliação e a tomada de decisão.

Entretanto, esta técnica somente é eficaz como forma de entrada de informação quantitativa e qualitativa, pois seus resultados devem ser revistos dentro da estrutura da experiência global e do julgamento da equipe de planejamento.

Assim, o autor apresenta (INSKEEP, 1991, p. 96) um exemplo de matriz de avaliação que pode ser aplicada para avaliar a importância relativa e a factibilidade do desenvolvimento de atrações turísticas em um país ou região. Outros critérios podem ser adicionados a esta matriz, baseados em outras considerações aplicáveis à área ou projeto em questão.

Os aspectos a serem avaliados na área ${ }^{21}$ em questão são:

- características naturais dos atrativos turísticos:

- parques nacionais;

\footnotetext{
${ }^{21}$ Compreendem a primeira coluna da matriz, da esquerda para a direita.
} 
- trekking/zonas para passeio de contemplação;

- áreas de praias/marinas;

- complexos de cavernas;

- complexos de geysers;

- complexos termais;

- jardins botânicos;

- jardins zoológicos/safáris;

- características culturais:

- sítios arqueológicos;

- sítios históricos;

- museus;

- músicas e danças tradicionais;

- artesanatos;

- bairros tradicionais;

- festivais culturais;

- características especiais:

- cassinos;

- parques temáticos;

- duty-free shopping;

- centros de convenções

O autor observa ainda que a lista de atrativos ora proposta é apenas um exemplo, e que a lista a ser utilizada dependerá das características da área a ser avaliada. 
Estes aspectos devem ser avaliados em uma escala de 1 a 5 ou 1 a 10 , segundo os seguintes fatores de avaliação (que também podem ser modificados de acordo com a situação da área estudada) ${ }^{22}$ :

- acessibilidade;

- factibilidade econômica do desenvolvimento;

- impacto ambiental do desenvolvimento;

- impactos sociocultural do desenvolvimento;

- importância nacional/regional;

- importância internacional

Ao final, deve-se obter o total de cada atrativo somando-se a pontuação obtida em cada critério e, se necessário, registrar comentários a respeito da avaliação.

Embora possa ser lido na introdução deste capítulo que não seriam abordadas teorias e/ou metodologias que enfatizassem apenas algum componente específico da oferta turística - dada a preocupação com a destinação como um todo -, optouse por apresentar a proposta de Inskeep por duas razões: primeiramente, deve-se destacar que o autor ora estudado apresenta alguns fatores de avaliação até agora não mencionados pelos autores anteriormente citados.

Além disso, Inskeep inclui em sua lista de atrativos alguns elementos que, segundo as metodologias tradicionais de inventário da oferta turística, como a do

\footnotetext{
${ }^{22}$ Cada um dos fatores ocupa uma coluna da matriz, acrescentando-se, ao final, uma coluna para a somatória do valor total e para o registro de comentários.
} 
CICATUR/OEA, por exemplo, deveriam ser considerados como equipamentos e serviços turísticos, sugerindo que tal matriz possa avançar na direção de uma complementação com os demais componentes da oferta turística.

\subsection{A Abordagem da Avaliação Regional do Potencial de Desenvolvimento Turístico de Gunn ${ }^{23}$}

Gunn (1980, p.261-262), ao constatar o aumento das preocupações que trespassam o desenvolvimento de áreas turísticas, propõe um conceito que concerne à determinação de zonas geográficas que, em função da força de certos fatores localizacionais e organizacionais, tem grande potencial turístico para um futuro desenvolvimento turístico e afirma que, dentre outros aspectos, as atrações turísticas desempenham um importante papel neste processo de desenvolvimento. Segundo Gunn (1980, p.262), as atrações e muitos outros aspectos importantes do desenvolvimento turístico

[...] dependem conjuntamente, em variados graus, de fatores físicos e de fatores programáticos" e que "quando estes fatores são bem conhecidos e identificados, melhores avaliações das futuras decisões políticas podem ser tomadas ao nível da localidade.

Os fatores físicos derivam do exame das variadas possibilidades de atividades turísticas e dos aspectos físicos dos quais depende seu desenvolvimento: água, vida aquática, cobertura vegetal, vida selvagem, pestes; clima, atmosfera, topografia, solos, geologia; história, etnicidade, arqueologia, lendas; estéticas;

\footnotetext{
${ }^{23}$ Os textos referentes a este subtítulo foram traduzidos livremente a partir do original em inglês de Gunn e citado na bibliografia desta tese. Entende-se por tradução livre a tradução textual e interpretativa que, embora possa não ser fiel ao estilo do autor, é fiel ao conteúdo da obra, mantendo seus meandros técnicos e conceituais.
} 
instituições, indústrias, atrações; centros de serviços; e transporte e acesso. A estes, devem ser adicionados os fatores programáticos, como: mercados, promoção, informação, direção, socioambiental; e os agentes de implementação (GUNN, 1980, p.263).

Outro elemento conceitual é o reconhecimento da diferença entre o turismo de vista panorâmica (turismo de contemplação) e o turismo de destinação. O desenvolvimento do turismo de contemplação não precisa lidar com o uso repetitivo dos lugares pelos mesmos usuários, de tempos em tempos.

A visita a lugares históricos e a atrações naturais, bem como a diversão com a contemplação de cenários de beira de estrada, são bons exemplos da modalidade. No caso do turismo de destinação, no entanto, o desenvolvimento requer um conjunto de atividades nas atrações que são repetitivas e mais limitadas a uma vizinhança localizada.

Por exemplo, atividades em áreas de convenções, resorts, férias em casa e acampamentos pedem o desenvolvimento de atrações minimamente diferentes, bem como de fatores fundamentais (1980, p.263).

A fim de demonstrar a aplicação de seus conceitos, Gunn selecionou arbitrariamente 20 condados da região centro-sul do Texas. O primeiro passo consistiu na pesquisa dos elementos físicos da região. A partir do estudo dos documentos, reconhecimento da região e entrevistas com conhecedores da área, 
foram produzidos declarações narrativas e mapas. Procedimentos de mapeamento foram usados para indicar os fundamentos para as áreas com maior potencial.

Foram atribuídos pesos ou índices separados dados a cada elemento físico, com base na premissa de que estes elementos não têm peso igual no suporte ao desenvolvimento do turismo de contemplação ou de destinação - estes pesos foram desenvolvidos por um grupo de técnicos. Obviamente, segundo Gunn (1980, p.263) trata-se de uma avaliação subjetiva, mas baseada não em capricho ou orgulho, mas em documentação e fatos sobre cada um dos elementos. Para mapeamento, cada índice foi dividido em cinco níveis de suporte potencial, variável de forte a fraco. O número resultante pôde então ser usado na preparação de um mapa para cada um dos elementos.

\begin{tabular}{|l|c|c|c|c|c|c|}
\hline \multicolumn{1}{|c|}{ Fatores } & \multirow{2}{*}{ Índices } & \multicolumn{5}{c|}{ Escalas } \\
\cline { 2 - 7 } & & $\begin{array}{c}\text { Muito } \\
\text { Fraco }\end{array}$ & Fraco & Moderado & Forte & $\begin{array}{c}\text { Muito } \\
\text { Forte }\end{array}$ \\
\hline Água, vida aquática & 8 & 0 & $1-2$ & $3-4$ & $5-6$ & $7-8$ \\
\hline Topografia, solos, geologia & 10 & $0-1$ & $2-3$ & $4-6$ & $7-8$ & $9-10$ \\
\hline $\begin{array}{l}\text { Cobertura vegetal, vida } \\
\text { selvagem, pestes }\end{array}$ & 7 & 0 & $1-2$ & $3-4$ & $5-6$ & 7 \\
\hline Clima, atmosfera & 3 & 0 & 1 & 1 & 2 & 3 \\
\hline Estética atrações, & 13 & $0-1$ & $2-4$ & $5-7$ & $8-10$ & $11-13$ \\
\hline $\begin{array}{l}\text { Existência de } \\
\text { indústrias, instituições }\end{array}$ & 10 & $0-1$ & $2-3$ & $4-6$ & $7-8$ & $9-10$ \\
\hline $\begin{array}{l}\text { História, etnicidade, } \\
\text { arqueologia, lendas }\end{array}$ & 9 & $0-1$ & $2-3$ & $4-5$ & $6-7$ & $8-9$ \\
\hline Centros de serviços & 15 & $0-2$ & $3-5$ & $6-9$ & $10-12$ & $13-15$ \\
\hline Transportes, acessos & 25 & $0-4$ & $5-9$ & $10-15$ & $16-20$ & $21-25$ \\
\hline Total & 100 & \multicolumn{7}{|l}{} & & & \\
\hline
\end{tabular}

Quadro 15 - Escalas de Índices para o Turismo de Contemplação Fonte: GUNN, 1980, p.265.

\begin{tabular}{|l|c|c|c|c|c|c|}
\hline \multirow{2}{*}{ Fatores } & \multirow{2}{*}{ Índices } & \multicolumn{3}{c|}{ Escalas } \\
\cline { 2 - 7 } & & $\begin{array}{c}\text { Muito } \\
\text { Fraco }\end{array}$ & Fraco & Moderado & Forte & $\begin{array}{c}\text { Muito } \\
\text { Forte }\end{array}$ \\
\hline Água, vida aquática & 24 & $0-4$ & $5-9$ & $10-14$ & $15-19$ & $20-24$ \\
\hline Topografia, solos, geologia & 10 & $0-1$ & $2-3$ & $4-6$ & $7-8$ & $9-10$ \\
\hline $\begin{array}{l}\text { Cobertura vegetal, vida } \\
\text { selvagem, pestes }\end{array}$ & 8 & 0 & $1-2$ & $3-4$ & $5-6$ & $7-8$ \\
\hline Clima, atmosfera & 13 & $0-1$ & $2-4$ & $5-7$ & $8-10$ & $11-13$ \\
\hline Estética & 7 & 0 & $1-2$ & $3-4$ & $5-6$ & 7 \\
\hline
\end{tabular}




\begin{tabular}{|l|c|c|c|c|c|c|}
\hline $\begin{array}{l}\text { Existência de atrações, } \\
\text { indústrias, instituições }\end{array}$ & 5 & $0-1$ & 2 & 3 & 4 & 5 \\
\hline $\begin{array}{l}\text { História, etnicidade, } \\
\text { arqueologia, lendas }\end{array}$ & 3 & 0 & 1 & 1 & 2 & 3 \\
\hline Centros de serviços & 10 & $0-1$ & $2-3$ & $4-6$ & $7-8$ & $9-10$ \\
\hline Transportes, acessos & 20 & $0-3$ & $4-7$ & $8-12$ & $13-16$ & $17-20$ \\
\hline Total & 100 & & &
\end{tabular}

Quadro 16 - Escalas de Índices para o Turismo de Destinação

Fonte: GUNN, 1980, p.266.

Os vários mapas desenhados à mão foram traduzidos para o computador a fim de que pudessem ser agregados. Embora os totais fossem os maiores, a força do suporte do desenvolvimento do turismo poderia ser ainda maior. Pelo uso do computador, com a ajuda de um programa chamado SYMAP, que simula uma grade em forma de mapa, cada uma das células para a escala do mapa usado representava 6,5 milhas quadradas.

Quando os mapas em computador foram agregados, não foi necessário imprimir os vários estágios - no entanto, é possível fazê-lo. A principal vantagem do uso do computador é que cada um dos valores pode ser guardado a fim de produzir os totais ${ }^{24}$.

${ }^{24}$ Gunn (1988, p.227-228) apresenta, em outra obra publicada posteriormente, um maior detalhamento da proposta de utilização de computadores para tal finalidade:

A técnica das "camadas de mapa sobrepostas" por computador é útil nesta tarefa. "A sobreposição múltipla no mapa é um processo analítico que envolve a avaliação sistemática e a graduação dos atributos desejados e da distribuição de suas localizações" (Mutunayagama e Bahrami: 1987, 100). [...]

Mutunayagama e Baharami descrevem o processo que consiste em dois procedimentos. Primeiro, o procedimento off-line, de responsabilidade do pesquisador cartográfico, consiste na criação de um mapa feito à mão, baseado no estudo dos atributos particulares e de sua distribuição pela região. [...] Uma segunda parte do procedimento off-line é pesar cada um dos mapas para refletir a relativa importância de cada fator de atributo. Pelo fato de este passo não dispor de precisão de engenharia ou científica, o melhor método até agora tem sido o uso de um painel de especialistas. Uma abordagem delphi, usando várias iterações, pode trazer mais consenso na importância relativa dos vários fatores para o desenvolvimento futuro do turismo, considerando a ampla gama da preferência do mercado e das atividades necessárias.

O segundo procedimento, on-line, envolve a tradução dos mapas no computador, em camadas sobrepostas. [...] A cópia eletrônica resultante oferece uma variedade de sombreamentos que podem ser interpretados por um cartógrafo e analista a fim 
Para ilustrar graficamente estes totais, a contagem máxima é dividida em dez níveis, impressos como símbolos, do mais escuro ao mais claro, indicando os níveis mais altos e mais baixos. Para facilitar a identificação do potencial, estes dez símbolos foram graficamente agrupados em cinco, indicando áreas onde os fatores combinados são fortes até fracos (GUNN, 1980, 264-267).

O estudo das informações da pesquisa de todos os fatores e dos resultados do mapeamento por computador levam a conclusões localizadas sobre quais tipos de desenvolvimento tinham potencial e onde tal desenvolvimento deveria logicamente acontecer. [...] Graficamente, quatro elementos principais estão ilustrados: zonas com o potencial mais elevado (áreas brancas), áreas com elevado potencial para futuros complexos de atrações (estrelas), centros de serviços comunitários chave (pontos) e transporte e acesso (traços) (GUNN, 1980, p.267).

Gunn (1980, p.268) apresenta, ainda, os desenvolvimentos potenciais do turismo de contemplação que poderiam acontecer por conta da análise resultante deste conceito. Os primeiros fundamentos seriam lugares históricos e recursos naturais e artificiais. Em muitos casos, não se promoveu ainda nenhum desenvolvimento em pontos históricos de interesse com muito potencial para complexos grandes e muito significativos.

O desenvolvimento de museus, a recuperação de edifícios históricos, a melhoria da vizinhança, a identificação de lugares e edifícios históricos poderiam oferecer oportunidades para caminhadas ou passeios de carro, bem como para a realização de eventos especiais em praças, shoppings ou parques. Características interessantes do terreno, tais como reservatórios, rios, florestas isoladas, praias e 
recursos costeiros podem geram muitas oportunidades para o desenvolvimento da atividade turística de contemplação.

Uma zona foi identificada em qualquer lugar onde parecia existir um grupo destes potenciais complexos de atração em volta de um centro de serviços e perto de um corredor de circulação. Uma zona é simplesmente uma área generalizada na qual se pode desenvolver um número de complexos, servidos pelo mesmo centro de serviços e pelo mesmo aceso.

Por conta da importância das rotas de viagem para a contemplação, todos os corredores de transporte, quando finalmente definidos, precisariam ser estudados e possivelmente redesenhados para servir adequadamente às funções do turismo (GUNN, 1980, p.269).

Para o turismo de destinação, Gunn (1680, p.270-271) analisa que a mesma região tem bom acesso por rodovia e algum acesso aeroviário para mercados existentes e potenciais e identifica cinco destinos que contêm recursos coesos, capazes de conduzi-los a um desenvolvimento turístico futuro considerável.

Embora não seja tão esclarecedora quanto o mapeamento, a pesquisa dos fatores programáticos leva-nos a importantes conclusões sobre 0 potencial de desenvolvimento. As limitações estudadas não permitem aprofundamento adequado das entradas de dados dos cidadãos locais. Certamente, qualquer análise regional deve ter uma grande quantidade de dados relativos aos cidadãos locais, governos, empreendedores e potenciais investidores (GUNN, 1980, p.274). 
Este conceito, segundo o autor (GUNN, 1980, p.275), está direcionado ao aumento da habilidade das regiões de fazer avaliações preliminares de suas oportunidades de desenvolvimento do turismo. Em um tempo no qual algumas terras mostram sinais de excesso de desenvolvimento e outras de subdesenvolvimento, avaliações de oportunidades podem ser de grande valor.

Este conceito não tem como objetivo abreviar ou diminuir decisões importantes de empreendedores. Isto não inclui a viabilidade de projetos individuais. Ele sugere que, ao invés de atual abordagem acidental do uso da terra, deve-se conduzir um estudo dos fatores fundamentais básicos para o turismo, que pode oferecer diretrizes mais sofisticadas. Sem estas diretrizes, uma ênfase exagerada na promoção pode mascarar a importância crítica do desenvolvimento do produto turístico (GUNN, 1980, p.275-276).

Por fim, Gunn (1980, p.276) acredita que à medida em que novas técnicas de avaliação de pesquisa surgem, podem ser obtidas políticas e decisões mais adequadas sobre o desenvolvimento da terra para o turismo. Talvez novas abordagens do desenvolvimento possam levar o turismo a padrões de crescimento que possam ser mais aceitáveis, dos pontos de vista social, econômico e ambiental.

\subsection{0 Índice de Potencial Turístico de Ferrario}

Dedicando-se desde a década de 1970 à avaliação de recursos e de potenciais turísticos, Ferrario (1979) realizou uma exaustiva pesquisa de recursos turísticos 
na África do Sul, combinando características de várias metodologias. Primeiramente, foram inventariadas 2.300 características da oferta turística mencionadas em dez guias turísticos.

Em seguida, estas características foram classificadas em 21 categorias e avaliadas com base em dois critérios: atração e disponibilidade, usando a seguinte fórmula (FERRARIO, 1979 apud PEARCE, 1991, p. 54):

$$
I=\frac{A+B}{2}
$$

onde:

I = índice de potencial turístico;

A = componente de atração ou demanda;

$B=$ componente da disponibilidade ou oferta

A demanda foi avaliada (FERRARIO, 1979 apud PEARCE, 1991, p. 54-55) primeiramente mediante uma pesquisa de grande escala realizada com os visitantes, por meio da qual demonstrou-se a existência de uma forte preferência, dentre as 21 categorias supramencionadas, pelas seguintes características ambientais: vista cênica e paisagens, vida selvagem e vegetação natural. A porcentagem de preferência para cada categoria foi obtida tomando-se com índice o da demanda turística, reduzindo-se a uma escala de 1 a 10 (por exemplo, 77\% foi convertido a 7,7$)$.

Cada um dos 2.300 atrativos individuais da África do Sul foi avaliado posteriormente, ponderando-se seu índice de categoria mediante o coeficiente 
obtido dos guias turísticos, ou seja, considerando quantos dos dez guias traziam informações sobre aqueles atrativos. Para novamente colocar-se o valor resultante em uma escala de 1 a 10, dever-se-ia extrair a raiz quadrada do produto (FERRARIO, 1979 apud PEARCE, 1991, p. 55) - com a inclusão deste novo coeficiente de ponderação $(\mathrm{G})$, a fórmula converteu-se em:

$$
I=\sqrt{\frac{A G+B}{2}}
$$

Os valores do índice de acessibilidade (B) foram determinados mediante o uso de seis critérios que supostamente afetavam a oferta: aproveitamento das estações, acessibilidade, quantidade de admissões, importância, fragilidade e popularidade. De acordo com (FERRARIO, 1979 apud PEARCE, 1991, p. 55),

Pediu-se aos "influentes da comunidade" em nível nacional, que classificassem os atrativos individuais de sua área com relação a estes seis critérios de acordo com uma escala nominal descritiva. Estas respostas foram transformadas posteriormente em um índice numérico ponderado, e foram calculadas as médias das diferentes avaliações que cada atrativo recebeu. Depois de representar graficamente estes valores, os grupos de atrativos foram classificados em quadros e, além disso, ponderados mediante cifras auxiliares a partir do princípio de que a soma de muitos índices baixos em um quadro, que representava um grupo de características de menor importância, não poderia ser numericamente equivalente à presença, em outro quadro, de um índice isolado, correspondente a um atrativo principal.

Identificaram-se, pois, vinte regiões turísticas no território conjunto da África do Sul, Lesoto e Suazilândia, ao se agrupar os quadros obtidos - estes resultados pareciam corresponder bastante bem aos padrões de demanda existentes, o que, segundo Pearce talvez não resulte surpreendente, dada a alta ponderação final proporcionada pelas cifras auxiliares. 
O autor pontua (PEARCE, 1991, p. 55): "ainda que com suas limitações, estes documentos sugerem que é possível avaliar com objetividade razoável um conceito tão abstrato e intangível como é a atração e delimitar variações espaciais onde esta ocorre".

Embora a observação de Pearce corrobore os princípios que norteiam este trabalho, deve-se lamentar a ausência de explicações adicionais sobre a utilização das referidas "cifras auxiliares" que, certamente, possibilitariam uma compreensão mais completa da proposta metodológica de Ferrario.

\subsection{A Avaliação do Potencial das Áreas de Desenvolvimento Turístico do Plano Nacional de Desenvolvimento Turístico da Tailândia}

Em 1974, por solicitação da organização turística nacional da Tailândia, iniciaramse os preparativos para a elaboração do Plano Nacional de Desenvolvimento do Turismo da Tailândia, que teria como objetivo guiar tanto o governo como a iniciativa privada no que diz respeito ao crescimento futuro que se vinha observando naquele país.

Este Plano deveria, ainda, servir como marco para realizar estudos de factibilidade, e possibilitar o desenvolvimento de planos detalhados para as áreas que seriam eleitas como turísticas (PEARCE, 1991, p. 103).

O estudo, empreendido por uma empresa de assessoria estrangeira e por uma empresa tailandesa, resultou em um informe final no qual Pearce baseou-se para ilustrar as possibilidades de aplicação da perspectiva espacial ao planejamento 
nacional do turismo, considerado por ele como um bom exemplo de tal aproveitamento, revelando, ainda, como o planejamento espacial guarda relação com outros aspectos do processo de planejamento.

A análise da demanda e da oferta foi acompanhada pela formulação de objetivos e pautas para o desenvolvimento. Isto, por sua vez, conduziu à identificação de áreas potenciais de desenvolvimento, à formulação de um plano de desenvolvimento a longo prazo e ao estabelecimento de um programa de desenvolvimento até 1980 (TDC-SGV, 1976 apud PEARCE, 1991, p. 104).

A análise da oferta começou com um inventário dos atrativos do país. Foram identificados, classificados (por tipo e grau de importância) e inseridos em um mapa 510 atrativos. Posteriormente, foram estabelecidas 16 áreas turísticas de importância, utilizando-se, segundo o estudo citado por Pearce, dois critérios:

- os atrativos deveriam estar a distâncias bastante curtas uns dos outros;

- estes atrativos deveriam ter um alto grau de qualidade e peculiaridade.

Posteriormente, estas 16 áreas foram ponderadas mediante outros critérios para estabelecer prioridades de desenvolvimento, conforme quadro a seguir (TDC-SGV, 1976 apud PEARCE, 1991, p. 105) - em particular, com relação ao modelo nacional adotado de "turismo-recreação", atribuiu-se importância à acessibilidade e à pressão de áreas urbanas:

PRINCIPAIS ÁREAS TURÍSTICAS
CRITÉRIOS DE AVALIAÇÃO

\begin{tabular}{l|l|l}
$(1)$ & $(2)$ \\
\hline
\end{tabular}

(3)

(4)

(5)

(6) 


\begin{tabular}{|c|c|c|c|c|c|c|c|}
\hline Bangkok/Pattaya & +++ & + & +++ & ++++ & +++ & +++ & 17 \\
\hline Chiang Mai & ++ & +++ & ++ & +++ & ++ & ++ & 14 \\
\hline Songkhla/Hat Yai & ++ & ++ & ++ & +++ & ++ & ++ & 13 \\
\hline Phuket & + & +++ & + & ++ & + & ++ & 10 \\
\hline $\begin{array}{c}\text { Hua Hin (Phetchaburi- } \\
\text { Prachuap) }\end{array}$ & + & + & + & + & + & + & 6 \\
\hline Kanchamaburri & + & ++ & 0 & + & + & + & 6 \\
\hline $\begin{array}{c}\text { Região Central Superior } \\
\text { (Área de Phitsanulok) }\end{array}$ & + & + & 0 & ++ & + & + & 6 \\
\hline Pattani/Narathiwat & + & + & 0 & ++ & + & + & 6 \\
\hline Khorat & + & 0 & + & + & + & + & 5 \\
\hline Ubon & + & 0 & + & ++ & + & - & 4 \\
\hline Chanthaburi/Trat & + & + & + & 0 & 0 & + & 4 \\
\hline Nakhon Si Thammarat & + & + & 0 & 0 & + & + & 4 \\
\hline Chumphon & + & ++ & - & + & 0 & 0 & 3 \\
\hline Trang/Phatthalung & + & + & - & + & + & 0 & 3 \\
\hline Chiang Rai & + & + & 0 & 0 & 0 & 0 & 2 \\
\hline Sakon Nakhon & + & + & 0 & 0 & 0 & - & 1 \\
\hline
\end{tabular}

Quadro 17 - Avaliação do Potencial das Áreas de desenvolvimento Turístico da Fonte: TDC-SGV, 1976 apud PEARCE, 1991, p. 106

Legenda: (1) Atrativos Primários

(2) Fatores Complementares

(3) Instalações Auxiliares

(4) Facilidade de Acesso

(5) Pressão da Recreação Urbana

(6) Pressão do Turismo

A avaliação acima observou as seguintes convenções:

- $(++++)=4$ pontos;

- $(+++)=3$ pontos - muito boa/alta;

- $(++)=2$ pontos - boa/alta;

- $(+)=1$ ponto - regular/moderada;

- $(0)$ = zero - pobre/baixa;

- $(-)$ = um ponto negativo - muito pobre/baixa. 
Especificamente para a coluna em que se avaliou a facilidade de acesso (4), observaram-se as seguintes convenções:

- $(++++)=4$ pontos - todos os meios de transportes incluem aeroporto internacional;

- $(+++)=3$ pontos - todos os meios de transportes incluem aeroporto semiinternacional;

- $(++)=2$ pontos - aeroporto doméstico;

- $(+)=1$ ponto - acesso por via férrea;

- $(0)=$ zero - acesso somente por autopista.

O estudo aponta (TDC-SGV, 1976 apud PEARCE, 1991, p. 105) que

Dentro destas 16 áreas elegeu-se posteriormente uma hierarquia de 21 centros turísticos para desenvolver em longo prazo. Três seriam desenvolvidos como centros regionais (primeiro escalão), dez como distritos (sendo seis de segundo escalão e quatro de terceiro escalão), e oito como albergues (quarto escalão). Além disso, doze povoados importantes com mais de 200.000 habitantes foram designados centros de apoio turístico na rede total de turismo (três de quatro escalão e nove de quinto escalão), sendo somente três deles localizados dentro das principais áreas turísticas.

O principal diferencial desta proposta reside na inserção de uma pontuação negativa, que acaba por diminuir a pontuação geral de cada área, explicitando melhor os aspectos favoráveis e desfavoráveis de acordo com cada critério. Outrossim, insere elementos importantes na avaliação, como pressão da recreação urbana e pressão do turismo sobre as áreas, possibilitando, ainda que de forma introdutória, a verificação da importância de impactos sobre o potencial das áreas em questão. 


\subsection{A Ferramenta para Determinação do Potencial Turístico de Casal}

Apesar de a ferramenta proposta por Casal (2002, p. 263-272) figurar neste estudo, certamente é a que apresenta o menor volume de considerações a respeito do tema aqui tratado. Tal ferramenta (assim denominada pelo autor) é utilizada para o planejamento do turismo alternativo (foco de sua obra), mais especificamente para o planejamento e desenho de serviços alternativos.

Segundo Casal (2002, p. 263), "uma das primeiras considerações que se apresentam [...] é aquela concernente a determinar o potencial turístico dos atrativos do serviço que se está planejando e desenhando".

Em sua opinião, tal determinação deve partir do inventário para, em seguida, utilizar-se de diversas ferramentas de análise das informações recolhidas anteriormente, dentre as quais encontra-se a ferramenta apresentada a seguir "[...] uma lista de perguntas que, junto com as informações recompiladas no inventário de necessidades e recursos, permitem ter um ponto de partida para a eleição dos atrativos que conformarão o serviço".

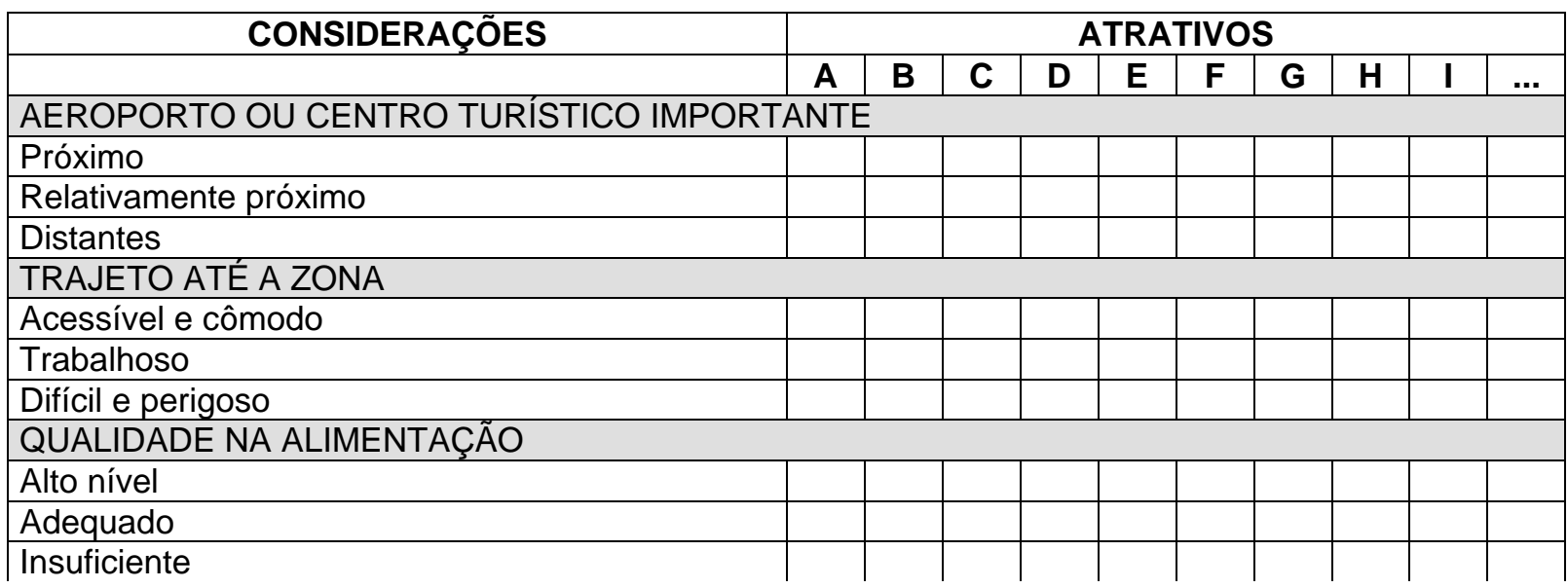




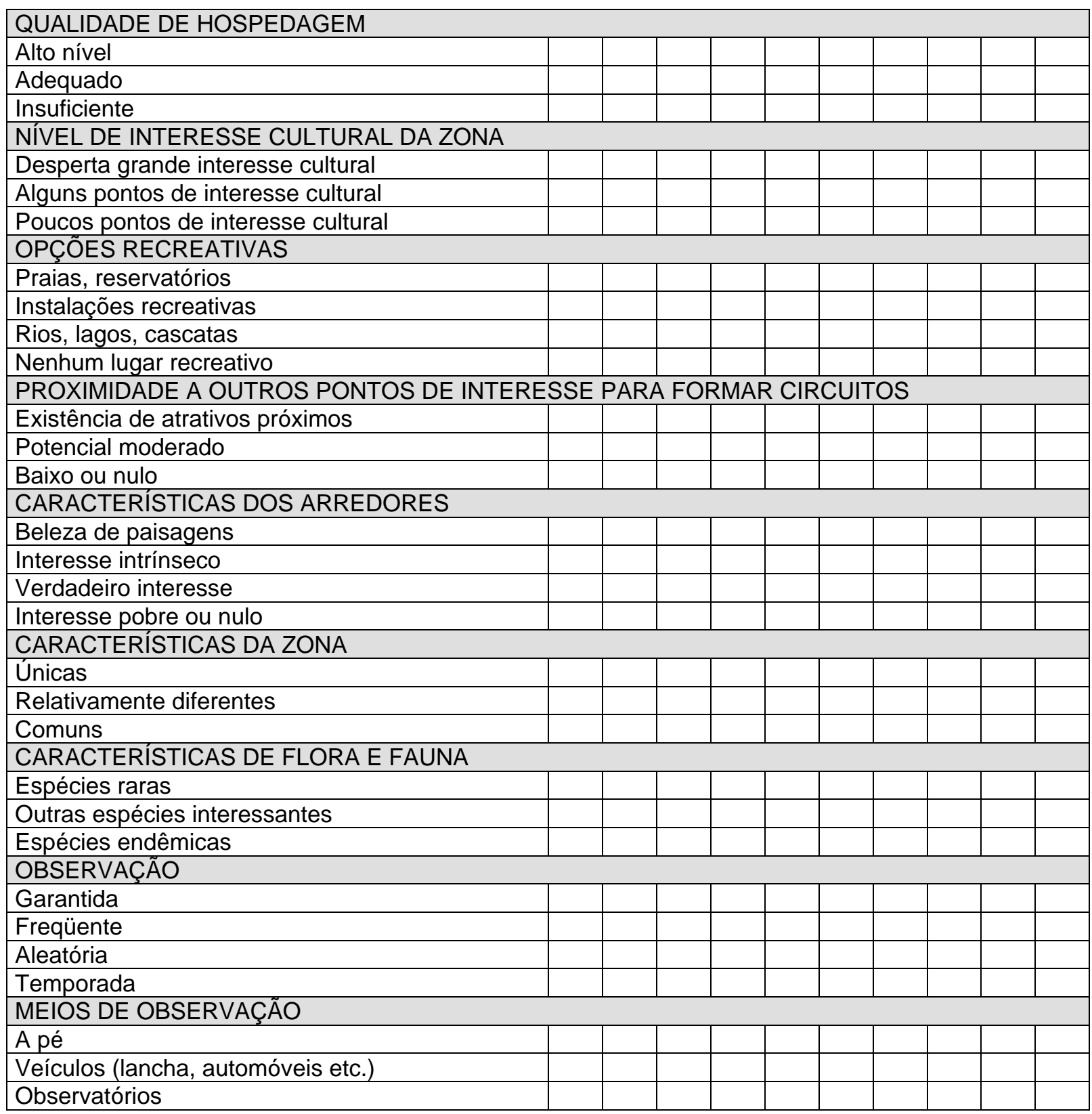

Quadro 18 - Considerações para a Avaliação do Potencial Turístico de Atrativos

Fonte: Adaptado de CASAL, 2002, p. 272

Ao contrário de outros métodos anteriormente apresentados, Casal aparentemente não mostra nenhuma preocupação com o sistema de pontuação ou com qualquer outro indicador de avaliação, além de apresentar aspectos no mínimo questionáveis do ponto de vista da subjetividade em sua lista de considerações sobre os atrativos. 
Outra crítica que pode ser feita a esta ferramenta - se é que ela pode efetivamente servir a tal fim - diz respeito à organização lógica do quadro supramencionado: parece mais apropriado que os atrativos estejam na primeira coluna do quadro e que os critérios segundo os quais seriam avaliados estejam nas demais colunas (e não ao contrário, como se vê).

\subsection{A Adaptação da Metodologia de Hierarquização de Recursos Turísticos da OEA para Aplicação na Comunidade Autônoma de La Rioja por Alvarez Cuervo e Leno Cerro}

Após apresentar a metodologia de inventário e hierarquização dos atrativos turísticos da $\mathrm{OEA}^{25}$, passível de aplicação em diversas escalas territoriais, Leno Cerro (1993, p. 46-50) destaca que tal metodologia sofre de alguns defeitos de relevante importância. Segundo ele,

a qualificação hierárquica de cada recurso em função do tipo de demanda que atrai é, na maior parte das vezes, muito subjetiva, pois, salvo em casos isolados, não existem estatísticas que permitam definir os distintos segmentos de demanda gerados pelo recurso; por outro lado, este método não consideração, na valoração dos recursos, uma série de fatores externos ao próprio recurso que, de um modo ou de outro, podem incrementar ou diminuir seu potencial turístico (LENO CERRO, 1993, p. 47).

A fim de superar alguns destes problemas, Alvarez Cuervo e Leno Cerro, em um trabalho relativo à Comunidade Autônoma de La Rioja (Espanha), propuseram a introdução de um fator de ponderação relativo à zona em que se localiza o recurso, que corrige a hierarquia inicial outorgada ao recurso e introduz na valoração três elementos considerados importantes pelos autores: a conectividade (acessibilidade

${ }^{25}$ Optou-se por não reproduzir, aqui, esta metodologia, devido ao fato desta ser amplamente conhecida, tendo sido, inclusive, adotada no Brasil pela então Empresa Brasileira de Turismo (1984). 
física), a concentração de recursos e a oferta de alojamento e restauração (CERRO, 1993, p. 47).

Este fator de ponderação espacial é o resultado do produto dos três elementos anteriormente mencionados, mais a soma de uma constante:

$$
F P(X)=F C(x) \times F C R(x) \times F H R(x)+K
$$

Onde:

$\mathrm{FP}(\mathrm{x})=$ fator de ponderação da zona $\mathrm{x}$;

$F C(x)=$ fator de conectividade da zona $x$;

$\operatorname{FCR}(x)=$ fator de concentração de recursos da zona $x$;

$\operatorname{FHR}(x)=$ fator de lugares de alojamento e restauração da zona $x$;

$K=$ constante $(k=1)$.

O primeiro passo para a aplicação desta metodologia foi dividir a Comunidade Autônoma em uma série zonas e calcular, para cada uma delas, os distintos elementos que intervêm em seu fator de ponderação.

O grau de conectividade foi determinado a partir de uma escala de 1 a 4 pontos, em função da densidade e qualidade da malha de estradas, na qual o valor 1 correspondia a áreas de escassa conectividade, através exclusivamente de estradas que ligam comarcas umas às outras e estradas locais (menos de $3 \mathrm{~km}$ de estrada por cada $10 \mathrm{~km}^{2}$ ), e o valor 4 a zonas ligadas por autopista e com uma malha compacta de estradas nacionais e a estradas que ligam comarcas umas às outras e estradas locais que proporcionem boa comunicação linear e transversal (um mínimo de $3 \mathrm{~km}$ de autopista e outros $4 \mathrm{~km}$ de estradas nacionais, estradas que ligam comarcas umas às outras e estradas locais por cada $10 \mathrm{~km}^{2}$ de superfície). O limiar de cada um destes níveis foi calculado sobre a base da realidade regional. 
- O fator de concentração de recursos de cada unidade espacial foi calculado com base no valor que representa a soma das hierarquias primárias de seus recursos com relação à soma das hierarquias primárias de todos os recursos presentes na Comunidade Autônoma. Para os autores (LENO CERRO, 1993, p. 48), hierarquias primárias são as pontuações outorgadas a cada recurso em função do tipo de demanda que este atrai, podendo ser assim classificadas:

- hierarquia 5: atrativo com características excepcionais e de grande significado para o mercado turístico internacional, capaz por si só de motivar uma importante corrente (atual ou potencial);

- hierarquia 4: atrativo excepcional capaz de motivar uma corrente (atual ou potencial) de visitantes nacionais ou estrangeiros, seja por si só ou em conjunto com outros atrativos contíguos;

- hierarquia 3: atrativo com alguma característica chamativa, capaz de interessar a visitantes provenientes de longa distância que tivessem chegado a esta zona por outras motivações turísticas;

- hierarquia 2: atrativo interessante, capaz de motivar correntes turísticas regionais ou locais;

- hierarquia 1: atrativos sem méritos suficientes para serem considerados nas hierarquias anteriores, mas que representam um papel complementar, diversificando e potencializando os demais recursos

De modo similar, foi estabelecido o fator de lugares de alojamento e restauração, considerando o peso relativo dos lugares em meios de hospedagem e restaurantes de cada uma das zonas com relação ao total regional. 
Por último, o valor ou hierarquia final dos recursos foi calculado multiplicando suas hierarquias primárias pelo fator de ponderação da zona nas quais estes recursos se localizam. Leno Cerro aponta (1993, p. 49) que

Esta modificação da metodologia da OEA, que apresenta algumas vantagens e inconvenientes, poderia servir de base para posteriores investigações que se aprofundem nos critérios de seleção dos distintos elementos que intervêm no fator de ponderação zonal e no peso relativo de cada um destes elementos. Não obstante, apesar das arbitrariedades que podem ser detectadas, esta modificação apresenta claros avanços com relação à metodologia original e inclui alguma novidade frente a outras metodologias de avaliação de recursos [...].

Salienta ainda que, ao contrário de outras metodologias por ele apresentadas na obra referenciada, optou nesta por conferir um maior peso específico ao que outros denominam fatores internos do recurso (fundamentalmente sua capacidade de atração) frente aos fatores externos (acessibilidade, equipamento turístico etc.).

Nas suas palavras,

Assim, em nosso caso, o fator de ponderação zonal (fatores externos) corrige unicamente a valoração inicial do recurso determinada por seu próprio poder de atração. Esta questão metodológica é especialmente válida na análise do potencial turístico de áreas rurais, já que normalmente estas se caracterizam por reunir recursos com um alto potencial turístico e possuir níveis muito baixos de acessibilidade e de equipamentos turísticos (LENO CERRO, 1993, p. 50).

Tais cuidados mencionados pelo autor quanto à adaptação da metodologia original demonstram um verdadeiro cuidado em oferecer subsídios à avaliação de áreas turísticas por meio da integração dos fatores específicos dos recursos turísticos 
com outros fatores que caracterizam as áreas turísticas (demais componentes da oferta).

\subsection{A Avaliação dos Recursos Turísticos da OMT}

A OMT publicou em 1978 um manual intitulado Avaliação dos Recursos Turísticos, cujo objetivo fundamental era (OMT, 1978, p. 1 apud LENO CERRO, 1996, p. 68)

estudar o modo de realizar uma análise tipológica e formar um inventário dos recursos turísticos atuais ou potenciais de uma região ou país determinado e propor medidas adequadas de proteção, conservação e aproveitamento destes recursos.

Segundo tal publicação, a partir da realização do inventário dos recursos turísticos e das informações recolhidas por meio deste processo a partir da utilização e fichas, seria possível efetuar uma avaliação dos recursos, entendida como o processo que permitiria definir a importância atual e futura de um recurso turístico em relação a outros recursos disponíveis, de características homogêneas (LENO CERRO, 1993, p. 71-72).

Segundo Leno Cerro (1993, p. 72-74), esta avaliação se realiza a partir de uma série de fatores que se agrupam em duas grandes categorias:

- fatores internos: são aqueles que fazem referência às qualidades e valores específicos que possuem cada recurso. Dentro desta categoria, incluem-se dois 
tipos de fatores: os que fazem referência ao grau de utilização do recurso e os que se referem às características intrínsecas do recurso;

- grau de utilização do recurso:

- urbanização: avaliada segundo o tipo (urbanização turística, mista ou não turística), segundo a qualidade da construção e da ordenação urbana (boa, média ou má), e segundo a intensidade de urbanização do recurso (elevada, média ou deficiente);

- infra-estrutura: nesta epígrafe deve-se considerar as características das infra-estruturas em matéria de meios de transporte, o nível dos serviços oferecidos e o nível destes serviços com relação às necessidades da demanda;

- equipamentos e serviços turísticos: deve-se valorar tanto a qualidade como a quantidade dos meios de alojamento existentes (hoteleiros e extra-hoteleiros), da oferta turística complementar (alimentação, agências de viagens, espaços para eventos e esportes, etc.) e dos serviços turísticos (informação, comercialização e transporte);

- características intrínsecas: aspectos que definem a própria natureza do recurso e, portanto, apresentam uma grande variedade, segundo o recurso de que se trate;

- fatores externos: são aqueles que, de um modo direto, determinam a demanda final, limitando ou estimulando os valores internos do próprio recurso:

- acessibilidade: análise da quantidade e da qualidade dos acessos ao recurso a partir dos lugares de origem da demanda, bem como da disponibilidade de meios públicos de transporte; 
- proximidade a centros emissores: derivado do aspecto anterior e do princípio de gravidade: quanto menor for a distância que separa o recurso do centro emissor, maior será o poder de atração daquele;

- especificidade do recurso: trata-se de medir a valia turística do recurso em comparação com outros recursos da mesma natureza, considerando igualmente seu grau de singularidade;

- importância do recurso: determinada pelo impacto do recurso no mercado turístico e o volume de demanda que gera.

A avaliação final do recurso é efetuada, segundo o autor (LENO CERRO, 1993, p. 74), aplicando-se uma escala de valores a cada um dos fatores considerados, geralmente em uma escala de 0 a 3 pontos, que indica unicamente a intensidade do fator considerado. O valor turístico do recurso será determinado pelo produto das pontuações obtidas pelos valores internos e externos de tal recurso:

$$
\begin{gathered}
V T=x \times y \\
x=A+B+C+D \\
Y=E+F+G+H
\end{gathered}
$$

Onde:

VT = valor turístico do recurso;

$\mathrm{X}=$ soma das pontuações obtidas pelos fatores internos:

A = avaliação do elemento urbanização;

$B=$ avaliação das infra-estruturas;

C = avaliação dos equipamentos e serviços; 


\section{D = avaliação das características intrínsecas do recurso; \\ $y=$ soma das pontuações obtidas pelos fatores externos: \\ $E=$ avaliação das condições de acessibilidade; \\ $F=$ avaliação da proximidade a centros emissores; \\ $\mathrm{G}=$ avaliação da especificidade do recurso; \\ H = avaliação da importância do recurso.}

Segundo Leno Cerro (1993, p. 75),

[...] o objetivo principal do método não é a valoração do potencial turístico de um recurso concreto, mas sim determinar o valor de diversas zonas com o fim de estabelecer uma ordem de prioridade nos trabalhos de planejamento e desenvolvimento do turismo, sob a ótica do melhor aproveitamento dos meios humanos e econômicos limitados.

Esta ordem de prioridade ou, dito de outro modo, o valor turístico da zona, é estabelecido com base nos recursos turísticos que nela se localizam e nas características próprias do conjunto da zona. O procedimento de avaliação, muito similar ao já explicado para o caso dos recursos, parte da avaliação de uma série de fatores internos e externos que são recolhidos em uma ficha de inventário turístico para cada uma das zonas consideradas [...].

Neste caso, ainda segundo o autor (LENO CERRO, 1993, p. 75-76) também, o potencial turístico da zona analisada será determinado pelo produto das pontuações obtidas por seus valores internos e extremos:

$$
V T Z=F I \times F E
$$

Onde:

VTZ = valor turístico da zona;

$\mathrm{FI}=$ valor dos fatores internos da zona: soma dos valores dos fatores internos (A, B, C e D) dos $\mathbf{N}$ recursos presentes na área $\mathrm{x}$ :

$$
F I=\sum_{x=1}^{N} A_{x}+\sum_{x=1}^{N} B_{x}+\sum_{x=1}^{N} C_{x}+\sum_{x=1}^{N} D_{x}
$$

FE = soma dos fatores externos da zona:

$$
F E=E+F+G+H
$$


Onde:

$E$ = facilidades de acesso e comunicação a partir dos centros emissores;

$F=$ especificidade da zona em relação a outras;

$\mathrm{G}=$ proximidade de centros emissores;

H = importância turística da zona como fonte de atividades turísticas e de captação da demanda em relação às demais zonas.

Leno Cerro (1993, p. 76) afirma, por fim, que a partir dos valores obtidos para cada uma das zonas, pode-se estabelecer uma hierarquia destas segundo sua importância turística e, em função desta hierarquia, uma ordem de prioridades para sua planificação e desenvolvimento.

\subsection{A Medida da Atração Turística de Var, Beck e Loftus}

Leno Cerro (1993, p. 109) cita os estudos de Clawson e Knetsch (1996), que serviram de base para Var, Beck e Loftus sugerirem que a atração turística de uma área pode expressar-se pela equação:

$$
T j=f\left(N_{j}, S_{j}, H_{j}, R_{j}, I_{j}\right)
$$

Onde:

$T_{j}=$ atração turística;

$\mathrm{N}_{\mathrm{j}}$ = fatores naturais;

$\mathrm{S}_{\mathrm{j}}=$ fatores sociais;

$\mathrm{H}_{\mathrm{j}}=$ fatores históricos;

$\mathbf{R}_{\mathrm{j}}=$ equipamentos recreativos e comerciais;

$\mathrm{I}_{\mathrm{j}}$ = infra-estruturas, alojamento e restauração (LENO CERRO, 1993, p. 109).

Cada um destes conjuntos de fatores é separado em uma série de critérios que são os que realmente são utilizados para a valoração da atração turística da zona. 
Estes critérios dependem, logicamente, das características do âmbito espacial que a ser analisado, razão pela qual devem ser selecionados aqueles considerados mais adequados em cada ocasião - no caso, foram selecionados 17 critérios para análise da região da Columbia Britânica (Canadá).

Em seguida, o autor procedeu à atribuição de pesos específicos para cada um dos critérios em função de sua própria capacidade de atração turística, independente de sua localização, ou seja, pretende-se julgar um tipo de recurso determinado e não um recurso concreto e, para realizar esta tarefa, foram selecionados 60 especialistas procedentes de um amplo espectro de campos profissionais, ponto de vista e localização geográfica, cuja função era representar uma massa de turistas o mais ampla possível. O estudioso aponta que

Cada uma destas pessoas outorgou uma pontuação para cada um dos critérios $\left(W_{1}, W_{2} \ldots W_{17}\right)$ e tomando a média de tais pontuações, foi estabelecido um conjunto de fatores de ponderação cuja soma total era igual à unidade. Com a finalidade de poder contrastar estes resultados, elaborou-se uma amostra adicional composta por estudantes de graduação de Economia Regional, os quais foram submetidos à mesma entrevista.

\section{$[\ldots]$}

Se aplicamos a ambos os conjuntos de dados o coeficiente de correlação não paramétrico de Spearman, obtemos um valor de 0,66 , o que nos indica um alto grau de correlação positiva entre os rankings atribuídos pelo grupo de especialistas e pelo grupo de estudantes e cada um dos critérios. Este dado ratifica, de certo modo, uma certa coincidência nas valorações e, portanto, a certidão do método (LENO CERRO, 1993, p. 110-111).

Centrando-se exclusivamente nas ponderações obtidas juntos aos especialistas, Leno Cerro (1993, p. 112) observa o que parece ser um resultado constante nas 
diversas técnicas de valoração: uma alta pontuação dos fatores naturais e pontuações menores dos critérios de natureza social ou cultural.

Por último, o autor descreve (LENO CERRO, 1993, p. 113) que a mesma equipe de especialistas, como bons conhecedores da região analisada, pontuaram, a partir de uma escala de 1 a 100 pontos, cada um dos distritos de planejamento para cada um dos 17 critérios estabelecidos, obtendo-se assim um valor de atração para os 17 critérios em cada distrito $\left[\left(\mathrm{da}_{1}, \mathrm{da}_{2} \ldots \mathrm{da}_{17}\right), \quad\left(\mathrm{db}_{1}\right.\right.$, $\left.\left.\mathrm{db}_{2} \ldots \mathrm{db}_{17}\right) \ldots\left(\mathrm{dn}_{1}, \mathrm{dn}_{2} \ldots \mathrm{dn}_{17}\right)\right]$

Uma vez conhecidos os fatores de ponderação atribuídos pelos especialistas a cada critério $\left(W_{n}\right)$ e os valores de cada um dos fatores para cada distrito $\left(d_{n}\right)$, podese calcular o índice de atração total, multiplicando ambos os dados e somando os produtos obtidos de acordo com a fórmula:

$$
I A_{j}=\sum_{1=17}^{n}\left(W_{n} \times d_{j n}\right)
$$

Onde:

IA = índice de atração do distrito $\mathbf{j}$;

$\mathrm{W}_{\mathrm{n}}=$ fatores de ponderação dos critérios;

$\mathrm{d}_{\mathrm{jn}}=$ valor da pontuação obtida pelo distrito $\mathrm{j}$ em cada um dos critérios.

Com a finalidade de contrastar os índices obtidos em nível regional, estes resultados foram submetidos, segundo o autor (LENO CERRO, 1993, p. 113-114), a três testes: 
- coeficiente de correlação entre os índices de cada região e a distribuição percentual das pernoites entre as diversas regiões da Columbia Britânica;

- coeficiente de correlação entre os índices de atração e o quociente resultante da divisão do número de pernoites em uma região pelo número de pernoites totais na Columbia Britânica:

$$
\frac{P_{j}}{\sum P_{n}}
$$

- coeficiente de correlação entre os índices de atração e o quociente anterior menos a porcentagem de visitantes com motivações alheias ao lazer e ao turismo:

$$
\left(\frac{P_{j}}{\sum P_{n}}\right)
$$

Onde:

Vet $=$ visitantes não turísticos

O autor comenta (LENO CERRO, 1993, p. 114) que:

Os coeficientes de determinação $\left(R^{2}\right)$ obtidos nestes testes $(78,8$ com um nível de significação de 99\%; 66,7 com um nível de significação de $95 \%$ e $75,7 \%$ com um nível de significação de $99 \%$, respectivamente) demonstram o acerto do método, já que, salvo para o segundo teste, o índice de atração calculado explica porcentagens superiores aos $75 \%$ das visitas turísticas a este território canadense.

Segundo Leno Cerro (1993, p. 114), o método desenvolvido por Var, Beck e Loftus é particularmente interessante para efetuar-se comparações sobre o nível de atração de distintas regiões ou das diversas zonas que integram uma região e 
pode ser uma ferramenta muito útil para a tomada de decisões em planejamento turístico, ainda que, como advertem os próprios autores, deve ser utilizada em combinação com outros critérios.

Por outro lado, o autor critica o critério regional adotado pelos pesquisadores. Ele cita Pearce e afirma que a adoção apriorística de um marco regional baseado em aspectos administrativos ou de regiões de planejamento, como é o caso, nem sempre resulta adequado, pois "não há nenhuma razão inerente pela qual as regiões turísticas correspondam às unidades administrativas preexistentes" (PEARCE, 1981, p. 38 apud LENO CERRO, 1993, p. 114).

Após análise dos pressupostos teóricos neste capítulo, partimos para a apresentação dos municípios que, neste trabalho, servirão de objeto para a aplicação do modelo de avaliação de potencialidade turística desenvolvido pelo autor. 


\section{CONTEXTUALIZAÇÃO E DELINEAMENTO DOS MUNICÍPIOS- OBJETOS DE ESTUDO (GUARATINGUETÁ E CUNHA/SP)}

Antes de iniciar, propriamente, o detalhamento dos municípios escolhidos para aplicação do instrumento proposto no capítulo que se segue, cabe, aqui, uma explicação acerca da escolha de tais municípios. Esta escolha está relacionada à inserção dos mesmos no projeto governamental "Rede de Cooperação Técnica para a Roteirização - Região Sudeste", proposta que, por sua vez, está inserida no Programa de Regionalização do Turismo, descrito a seguir ${ }^{26}$.

\subsection{A Rede de Cooperação Técnica para a Roteirização - Macrorregião Sudeste como ação operacional do Programa de Regionalização do Turismo - Roteiros do Brasil}

A roteirização turística foi adotada pelo Ministério do Turismo no âmbito do Programa de Regionalização do Turismo - Roteiros do Brasil como uma das estratégias para atingir alguns dos objetivos específicos estabelecidos pelo Plano Nacional do Turismo 2003-2007, quais sejam: diversificar a oferta turística e estruturar os destinos turísticos (BRASIL, 2005b, p. 3). Segundo o ministério, a

Regionalização do turismo é um modelo de gestão de política pública descentralizada, coordenada e integrada, baseada nos princípios da flexibilidade, articulação, mobilização, cooperação intersetorial e interinstitucional e na sinergia de decisões.

Regionalizar é transformar a ação centrada na unidade municipal em uma política pública mobilizadora, capaz de provocar mudanças, sistematizar o planejamento e coordenar o processo de desenvolvimento local e regional, estadual e nacional de forma articulada e compartilhada.

\footnotetext{
${ }^{26}$ Embora esta tese não se proponha a analisar os programas e projetos aqui mencionados, acredita-se que uma breve descrição dos mesmos se faz necessária a fim de melhor situar o leitor no contexto em que se inserem os municípios escolhidos.
} 


\section{$[\ldots]$}

Compreender o Programa de Regionalização do Turismo é assimilar a noção de território como espaço e lugar de interação do homem com o ambiente, dando origem a diversas formas de se organizar e se relacionar com a natureza, com a cultura e com os recursos de que dispõe. Essa noção de território supõe formas de coordenação entre organizações sociais, agentes econômicos e representantes políticos, superando a visão estritamente setorial do desenvolvimento. Incorpora, também, o ordenamento dos arranjos produtivos locais e regionais como estratégico, dado que os vínculos de parceria, integração e cooperação dos setores geram produtos e serviços capazes de inserir as unidades produtivas de base familiar, formais e informais, micro e pequenas empresas, que se reflete no estado de bem-estar das populações. (BRASIL, 2004, p. 9)

Ainda, de acordo com o Ministério do Turismo (BRASIL, 2004, p. 9), adotar o modelo de regionalização do turismo exige:

- novas posturas e estratégias na gestão das políticas sociais;

- mudanças de relacionamento entre as esferas do poder público e a sociedade civil;

- negociação, acordo, planejamento e organização social;

- entender a região diferentemente da macrodivisão administrativa adotada no País - Norte, Nordeste, Sul, Sudeste e Centro-Oeste ${ }^{27}$;

- perceber o conceito como um esforço coordenado de ações integradas entre municípios, estados e países.

Embora os trabalhos da Rede de Cooperação para a Roteirização estejam, aparentemente, baseados nestas premissas, não é difícil notar que se trata de um processo assaz complexo e ambicioso, que exigirá ainda um prazo considerável para trazer os resultados esperados.

${ }^{27}$ Curiosamente, tal divisão foi respeitada pelo processo de roteirização, como se verá adiante. 
- As bases do Programa de Regionalização do Turismo - Roteiros do Brasil derivam do Macroprograma 4 do Plano Nacional do Turismo 2003-2007, que trata da estruturação e diversificação da oferta turística, "[...] reestruturado a partir do debate nacional com os segmentos representativos da sociedade, de modo a impulsionar o desenvolvimento sustentável das regiões" e devem orientar a ação executiva de acordo com as seguintes diretrizes (BRASIL, 2004, p. 10):

- ordenamento, normatização e regulação;

- informação e comunicação;

- articulação;

- envolvimento comunitário;

- capacitação;

- incentivo e financiamento;

- infra-estrutura;

- promoção e comercialização.

As diretrizes políticas do Programa estabelecem, ainda, as seguintes estratégias (BRASIL, 2004, p. 11):

- gestão coordenada;

- planejamento integrado e participativo;

- promoção e apoio à comercialização. 
Cada uma destas estratégias, com suas respectivas ações operacionais, É em relação à última das estratégias mencionadas que se estabelece a formação de redes como uma das ações operacionais do Programa (ao lado da educação para o mercado e de estratégias de promoção e apoio à comercialização):

A estruturação de roteiros traduz-se na concretização formal do processo de regionalização do turismo. A formação de redes de organizações assegura um processo contínuo de inovação, que é um dos determinantes da competitividade.

Nessa etapa, desenvolvem-se a relação de mercado dos agentes locais; reforçam-se ou estabelecem-se a integração dos arranjos produtivos locais e regionais; definem-se os padrões de qualidade dos produtos e serviços; promovem-se a qualificação e requalificação dos profissionais e dos prestadores de serviços turísticos; provocam-se o ordenamento e disponibilizam-se diretrizes e normas para a organização dos diferentes segmentos; ampliam-se os vínculos de relações entre pessoas, criando redes humanas capazes de articular mudanças nos modelos econômicos e sociais em curso, de modo a provocar o redirecionamento das políticas públicas voltadas para os diferentes espaços territoriais (BRASIL, 2004, p. 17).

Sobre a formação de redes, o Ministério do Turismo defende que

A cultura de relacionamentos expressa a vontade para a transformação, constitui a base para a cooperação e para o surgimento de lideranças, provocando a inovação. A formação de redes gera mudanças na gestão econômica, ao criar novas formas de produção a partir da articulação da oferta local e regional. Daí decorre a ampliação e a simbiose dos serviços turísticos, influenciando na esfera política, pelo processo participativo que se estabelece, e, também, na esfera cultural pela socialização, produção e difusão do conhecimento, estabelecendo uma nova ética de relacionamentos (BRASIL, 2004, p. 17).

Deriva, portanto, do Programa de Regionalização do Turismo - Roteiros do Brasil, a roteirização turística, um dos nove Módulos Operacionais do Programa, como forma de organizar e integrar a oferta turística brasileira, descrita em um documento de caráter norteador para a elaboração de roteiros turísticos (BRASIL, 
2005a) que apresenta, em sua introdução, algumas definições importantes para a compreensão do processo, como os de:

região turística: espaço geográfico que apresenta características e potencialidades $^{28}$ similares e complementares, capazes de serem articuladas e que definem um território;

produto turístico: conjunto de atrativos, equipamentos e serviços turísticos acrescidos de facilidades, ofertado de forma organizada por um determinado preço;

roteiro turístico: itinerário caracterizado por um ou mais elementos que Ihe conferem identidade. É definido e estruturado para fins de planejamento, gestão, promoção e comercialização turística;

rota turística: percurso continuado e delimitado cuja identidade é reforçada ou atribuída pela utilização turística;

destino turístico: local, cidade, região ou país para onde se movimentam os fluxos turísticos (BRASIL, 2005a, p. 6-7).

Dentro desta lógica, o referido documento salienta, ainda, que:

- uma região pode contemplar uma ou várias rotas e um ou vários roteiros;

- ao mesmo tempo, um roteiro turístico pode perpassar uma ou várias regiões;

- as rotas, os roteiros e os destinos turísticos podem constituir um produto turístico.

A roteirização é, pois, colocada como uma estratégia fundamental para a diversificação da oferta turística e para a inserção de produtos diferenciados nos mercados nacional e internacional, e é definida como "o processo que estrutura a oferta de uma região, em um produto rentável e comercialmente viável" (BRASIL, 2005a, p. 8). Nos moldes propostos pelo Ministério do Turismo, a roteirização deve possuir um caráter participativo, estimular a integração e o compromisso dos 
envolvidos no processo, constituir-se em um instrumento de inclusão social, resgate e preservação dos valores culturais e ambientais existentes e ter como foco a maximização de esforços e a construção de parcerias ${ }^{29}$ nos vários âmbitos (municipal, regional, estadual, nacional e internacional), de modo a buscar o adensamento dos negócios, na região turística. O ministério defende (BRASIL, 2005a, p. 8) a idéia de que

A roteirização auxilia 0 processo de identificação, elaboração e consolidação de novos roteiros turísticos. Além disso, diagnostica a necessidade de aumentar os investimentos em roteiros já existentes, seja na melhoria da estrutura atual, seja na qualificação dos serviços oferecidos. Dessa forma, auxilia o incremento do fluxo de turistas, aumenta a permanência média deles, nas regiões turísticas e, consequentemente, fomenta a circulação do dinheiro.

A roteirização teria por objetivo geral, "estruturar, qualificar e ampliar a oferta de produtos turísticos de forma integrada e organizada" (BRASIL, 2005a, p. 9) e, por objetivos específicos:

identificar e apoiar a organização de segmentos turísticos;

incentivar o empreendedorismo;

facilitar o acesso das micro e pequenas empresas do setor ao mercado turístico regional, estadual, nacional e internacional;

estimular a criação de novos negócios e a expansão dos que já existem; ampliar e qualificar serviços e equipamentos turísticos;

consolidar e agregar valor aos produtos turísticos;

fortalecer a identidade regional;

promover o desenvolvimento regional.

${ }^{28}$ Grifo nosso. 
Convém salientar que a roteirização turística é vista pelo Ministério do Turismo como um processo com finalidade mercadológica, o que torna necessária a elaboração de um plano de marketing que contemple a elaboração do produto, a atribuição de preço, a distribuição, a promoção e a comercialização do produto turístico, sendo que o documento ora apresentado enfoca as duas primeiras etapas supramencionadas, dispondo, o Programa, de documento específico sobre as demais ações. "Ao final da leitura dos dois documentos, as Instâncias de Governança Regionais ${ }^{30}$ em parceria com as demais entidades da região estarão preparadas para elaborar o Plano de Marketing do roteiro turístico" (BRASIL, 2005a, p. 11).

Segundo as orientações do Ministério do Turismo, ao se elaborar um roteiro turístico, é necessário basear-se na oferta turística efetiva e em uma demanda efetiva ou potencial, e sua operacionalização deve ocorrer por meio da promoção e comercialização; esse processo pressupõe, segundo o ministério (BRASIL, 2005a, p. 13), as seguintes ações prioritárias:

definir o responsável pela execução do trabalho (Órgãos Oficiais de Turismo das UFs, Instâncias de Governança Regionais, atores locais, consultoria especializada etc.);

identificar as instâncias de governança existentes na região turística (conselhos, comitês e fóruns de turismo - municipais e regionais -, dentre outras);

levantar e sistematizar informações, estudos, projetos e inventários referentes à oferta e à demanda turística;

\footnotetext{
29 "Considera-se como parceria um sistema de alianças, relativamente estável entre dois ou mais atores que trabalham em sinergia para atingir objetivos comuns, otimizando esforços" (BRASIL, 2005a, p.8).

30 "No âmbito do Programa de Regionalização de Turismo, a Instância de Governança é uma organização representativa dos poderes público e privado, da sociedade e dos municípios componentes das regiões turísticas, com o papel de coordenar, acompanhar e gerir o processo de regionalização do turismo na região turística. Pode ser um Conselho, um Fórum, uma Associação, um Comitê" (BRASIL, 2005a, p.11).
} 
elaborar ou consultar estudos de mercado potencial e concorrente;

identificar o potencial de competitividade e as adequações necessárias para estruturar um produto turístico;

identificar as linhas de financiamento existentes ou a capacidade de investimentos, público e privado, da região turística;

identificar a capacidade empresarial para fins de promoção e comercialização.

As informações obtidas por meio destas ações preparatórias devem subsidiar (BRASIL, 2005a, p. 13-14) os seguintes passos do processo de roteirização ${ }^{31}$ :

envolvimento dos atores;

definição de competências e funções;

avaliação e hierarquização dos atrativos turísticos;

análise de mercado e definição de segmentos;

identificação dos possíveis impactos socioculturais, ambientais e econômicos;

elaboração de roteiro específico;

levantamento das ações necessárias para implementação do roteiro turístico;

precificação e teste do roteiro turístico;

qualificação dos serviços turísticos;

promoção e comercialização;

monitoria e avaliação.

É, portanto, a partir deste contexto que se realiza um convênio entre o Ministério do Turismo, o Instituto Brasileiro de Turismo e o SEBRAE Nacional, do qual deriva, entre outros, o projeto de Formação de Rede de Cooperação Técnica para a Roteirização, que tem por objetivo geral a formação de agentes para o 
acompanhamento, estruturação e avaliação do processo de roteirização no Brasil, e por objetivos específicos (BRASIL, 2005b, p. 4):

\begin{abstract}
formar uma rede de conhecimento e cooperação entre agentes do setor público e privado para apoiar e implementar o processo de roteirização no País;

disseminar informações referentes à elaboração e estruturação de roteiros turísticos;

fortalecer o protagonismo e competências locais.
\end{abstract}

Foram identificados no País cinco roteiros para aplicação do Projeto, um para cada macrorregião brasileira, nos quais a atividade turística já vinha sendo desenvolvida e nos quais já havia, inclusive, parcerias estabelecidas entre a comunidade, empresários locais e poder público, segundo o Ministério do Turismo (BRASIL, 2005b, p. 5), a saber:

${ }^{31} \mathrm{O}$ documento em questão apresenta um detalhamento de cada um destes passos que não serão aqui detalhados por não constituírem foco principal desta tese. 


\begin{tabular}{|c|c|c|}
\hline MACRORREGIÃO & ROTEIRO TURÍSTICO & $\begin{array}{c}\text { REGIÕES TURÍSTICAS/ MUNICÍPIOS } \\
\text { CONTEMPLADOS }\end{array}$ \\
\hline Norte & $\begin{array}{l}\text { Roteiro da Integração } \\
\text { Vale do Acre/Peru }\end{array}$ & $\begin{array}{c}\text { Pólo Ecoturístico do Vale do Acre } \\
\text { (Assis Brasil, Brasiléia, Epitaciolândia, } \\
\text { Xapuri, Porto Acre e Puerto Maldonado } \\
\text { - Peru) }\end{array}$ \\
\hline Nordeste & $\begin{array}{c}\text { Roteiro Integrado } \\
\text { Ceará/Piauí/Maranhão }\end{array}$ & $\begin{array}{l}\text { Ceará: Macrorregião Turística Litoral } \\
\text { Oeste//biapaba (Barroquinha, } \\
\text { Camocim, Chaval e Jijoca de } \\
\text { Jericoacoara) } \\
\text { Piauí: Pólo Costa do Delta (Cajueiro da } \\
\text { Praia, Ilha Grande, Luís Correia e } \\
\text { Parnaíba) } \\
\text { Maranhão: Região Turística Delta das } \\
\text { Américas (Araióses, Paulino Neves e } \\
\text { Tutóia), Regiấo Turística Parque dos } \\
\text { Lençóis (Barreirinhas) }\end{array}$ \\
\hline Centro-Oeste & $\begin{array}{c}\text { Roteiro Integrado } \\
\text { Brasília/Chapada dos } \\
\text { Veadeiros }\end{array}$ & $\begin{array}{l}\text { Distrito Federal (Brasília, Brazlândia, } \\
\text { Sobradinho e Planaltina) } \\
\text { Goiás (Formosa, São Gabriel, São } \\
\text { João da Aliança, Alto Paraíso, São } \\
\text { Jorge, Colinas do Sul, Teresina de } \\
\text { Goiás, Cavalcante e São Domingos) }\end{array}$ \\
\hline Sudeste & $\begin{array}{c}\text { Roteiro Integrado Estrada } \\
\text { Real }\end{array}$ & $\begin{array}{c}\text { São Paulo (Guaratinguetá, Aparecida } \\
\text { do Norte [sic] }]^{32} \text {, Cachoeira Paulista, } \\
\text { Cruzeiro, Silveiras e Cunha) } \\
\text { Rio de Janeiro (Paraty }{ }^{33} \text { ) } \\
\text { Minas Gerais (Caxambu, São } \\
\text { Lourenço, São Sebastião do Rio Verde, } \\
\text { Itanhandu e Passa Quatro) }\end{array}$ \\
\hline Sul & $\begin{array}{c}\text { Roteiro Integrado } \\
\text { Missões/Foz do Iguaçu }\end{array}$ & $\begin{array}{c}\text { Paraná (Foz do Iguaçu e Guairá) } \\
\text { Rio Grande do Sul (Caibaté, Entre-ljuís, } \\
\text { Porto Xavier, Roque Gonzáles, Santo } \\
\text { Ângelo, São Luiz Gonzaga, São Miguel } \\
\text { das Missões e São Nicolau) }\end{array}$ \\
\hline
\end{tabular}

Quadro 19 - Roteiros Turísticos Integrados da Rede de Cooperação Técnica para a Roteirização

Fonte: BRASIL, 2005b, p. 5

${ }^{32}$ O nome oficial do município é Aparecida.

${ }^{33} \mathrm{O}$ nome do município foi mantido, nesta tese, conforme a grafia da fonte consultada (Paraty ou Parati), embora o Instituto Brasileiro de Geografia e Estatística registre apenas a grafia "Parati".

${ }^{34}$ Como será visto mais adiante (subcapítulo 2.2), o Roteiro Integrado Estrada Real teve outra configuração em termos de composição municipal. 
A Rede de Cooperação Técnica para a Roteirização é formada por diversos atores, relacionados abaixo, alguns dos quais estão diretamente envolvidos na execução do projeto (quatro primeiros) e outros atuam apenas como participantes da vivência do processo de roteirização (três últimos, incluindo os técnicos do Serviço Nacional de Aprendizagem Comercial - SENAC de cada Unidade da Federação, não incluídos no documento consultado):

- grupo consultivo: formado por seis representantes do Ministério do Turismo e por seis representantes do SEBRAE Nacional, responsáveis por diversas atribuições, como:

- participar na seleção dos consultores regionais;

- observar o processo de evolução de estruturação da Rede;

- acompanhar o repasse de metodologia de roteirização;

- sugerir indicadores de acompanhamento e resultados para a Rede;

- apresentar uma proposta para implementação de um segundo projeto de formação de rede para roteirização, a partir desta primeira experiência;

- sugerir e incentivar a criação de fóruns temáticos virtuais envolvendo a rede de participantes do Projeto;

- contribuir tecnicamente no processo de implementação da Rede de Cooperação nas cinco macrorregiões através de debates virtuais;

- reunir (virtual ou presencialmente) uma vez a cada dois meses para repasse e nivelamento das informações do processo em cada região;

- identificar e, se possível, sugerir ações para superar os principais gargalos do Projeto durante a execução; 
- consultor orientador: diretamente pautado pelas equipes técnicas do Ministério do Turismo e do SEBRAE Nacional, deveria apoiar os participantes da Rede por meio de repasse de informações e esclarecimentos, à distância e/ou in loco e teria a atribuição de orientar os consultores tutores quanto à estruturação, desenvolvimento e comercialização de roteiros turísticos; ${ }^{35}$

- consultor planejador: teria como responsabilidade animar a Rede de Cooperação Técnica, especialmente no início do processo, quando estaria sendo identificada a situação atual do roteiro e quando seriam agendadas as visitas técnicas a algumas das localidades que compõem o roteiro; ${ }^{36}$

- consultor tutor (um para cada macrorregião): contratado pelo SEBRAE da Unidade da Federação gestora do Projeto em cada macrorregião, tinha por objetivo integrar as ações de roteirização em execução nos diferentes estados diretamente envolvidos no roteiro em estudo, razão pela qual este deveria ter experiência com trabalhos de roteirização, sendo, preferencialmente, o próprio responsável pelo processo de roteirização da região em estudo; ${ }^{37}$

- técnicos do SEBRAE/UF: cada etapa da vivência do processo de roteirização deveria contar com um técnico do SEBRAE de cada Unidade da Federação participando do processo de estruturação do roteiro na macrorregião que integra. Este técnico deveria ter envolvimento com o Sistema de Gestão Orientado para o Resultado (GEOR), utilizado pelo SEBRAE, conhecimento sobre o desenvolvimento de produtos turísticos e sobre o Programa de Regionalização do Turismo - Roteiros do Brasil, e ser um gestor local ou

\footnotetext{
${ }^{35}$ No início do Projeto, tal função foi desempenhada pelo consultor Mário Petrocchi.

${ }^{36}$ No caso da Rede de Cooperação Técnica para a Roteirização da Região Sudeste, tal função foi desempenhada pela especialista em atividades de moderação Isabel Castro, que atuou também no último encontro presencial do grupo.

${ }^{37}$ No caso da Rede de Cooperação Técnica para a Roteirização da Região Sudeste, tal função foi desempenhada pelo consultor Flávio Vitarelli.
} 
estadual e, no que se refere ao perfil exigido, deveriam apresentar as seguintes características: flexibilidade, liderança, articulação e boa interlocução entre a comunidade e o trade turístico. Tinham como atribuições, segundo o ministério (BRASIL, 2005b, p. 6-7):

articular a logística necessária para a realização da vivência;

participar da vivência do processo de roteirização no roteiro turístico identificado em sua macrorregião de atuação;

animar e acompanhar uma rede de cooperação entre os participantes com o objetivo de facilitar e trocar experiências;

multiplicar o conhecimento adquirido em sua instituição.

- técnicos dos órgãos oficiais de turismo das Unidades da Federação: deveria ser um funcionário de carreira que conhecesse o Programa de Regionalização do Turismo - Roteiros do Brasil, bem como o processo de desenvolvimento de produtos turísticos e possuir as mesmas características e atribuições exigidas dos técnicos do SEBRAE;

- agentes multiplicadores: foram identificados seis consultores por macrorregião ${ }^{38}$ com conhecimentos referentes à roteirização turística no País para serem capacitados de acordo com as diretrizes de roteirização estabelecidas pelo Ministério do Turismo. Estes consultores deveriam já ter desenvolvido algum trabalho desta natureza e possuir as mesmas características exigidas dos técnicos do SEBRAE e dos órgãos estaduais de turismo, e teriam como atribuições (não remuneradas), estabelecidas em termo de compromisso (BRASIL, 2005b, p. 6-10):

apresentar uma proposta de síntese metodológica para o roteiro em estudo;

\footnotetext{
${ }^{38}$ No caso da Rede de Cooperação Técnica para a Roteirização da Região Sudeste, os consultores selecionados eram dos Estados de Minas Gerais e Rio de Janeiro, que poderão atuar em toda a macrorregião para a multiplicação do processo de roteirização.
} 
apresentar, ao final da vivência, relatório sobre o roteiro estudado, e disponibilizar tais informações para o SEBRAE e para o Ministério do Turismo;

multiplicar o conhecimento adquirido para os atores do trade turístico e para a comunidade local, por meio de duas oficinas regionais, sob o acompanhamento dos técnicos dos órgãos oficiais de turismo e do SEBRAE de cada Unidade da Federação da macrorregião específica.

A indicação dos representantes dos órgãos oficiais de turismo e do SEBRAE de cada Unidade da Federação foi feita pelas respectivas instituições, tendo ficado a cargo do Ministério do Turismo e do SEBRAE Nacional verificar se aqueles atendiam ao perfil solicitado.

Já a seleção dos agentes multiplicadores foi feita pelo grupo consultivo, por meio de análise de currículos, do perfil dos candidatos e da realização de entrevistas. De acordo com a proposta (BRASIL, 2005b, p. 10-11),

A vivência do processo de roteirização terá como base o documento "Orientações para Elaboração de Roteiros Turísticos", elaborado pelo Ministério do Turismo, que apresenta como passos para o processo de roteirização os seguintes:

a) envolvimento dos atores;

b) definição de competências e funções;

c) avaliação e hierarquização dos atrativos;

d) análise de mercado e definição de segmentos alvo;

e) identificação das vocações turísticas ${ }^{39}$ e elaboração de roteiro específico;

f) identificação dos possíveis impactos socioculturais, ambientais e econômicos;

${ }^{39}$ Aspecto particularmente interessante para o propósito deste tese que, se ocorreu no caso da Rede de Cooperação Técnica para a Roteirização da Região Sudeste, não foi a partir de qualquer metodologia claramente definida, mas sim de acordo com o senso comum habitualmente utilizado pelo mercado turístico. 
g) levantamento das ações necessárias para implantação do roteiro turístico;

h) precificação e teste do produto;

i) qualificação dos serviços turísticos;

j) promoção e comercialização;

k) monitoria e avaliação. ${ }^{40}$

Segundo o Ministério do Turismo (BRASIL, 2005b, p. 11), cada roteiro estudado encontrava-se, no início do processo, em um estágio de desenvolvimento diferente, o que exigiria uma identificação do passo mais adequado para o início dos trabalhos e, para que não houvesse prejuízo quanto ao conhecimento a ser adquirido, deveria haver no início da vivência o repasse de informações sobre os passos já executados no roteiro em estudo.

No entanto, convém salientar que, no caso da Rede de Cooperação para a Roteirização da Região Sudeste, nem todos os passos acima arrolados foram trabalhados e uma das razões para que isto acontecesse foi a definição, por parte do Ministério do Turismo no início do processo, de que não se tratava de um processo mais amplo de planejamento turístico, mas sim de um trabalho voltado para o mercado, o que excluiu, por exemplo, as ações (c) e (f).

Da mesma forma, outras ações deixaram de ser executadas pela redefinição da atuação e do papel da Rede - chegou-se à conclusão, por exemplo, que não seria papel da Rede formatar roteiros, o que caberia ao setor empresarial, mas sim o de

\footnotetext{
40 Embora tal listagem já tenha sido mencionada anteriormente, optou-se por transcrevê-la novamente em decorrência das diferenças da redação entre as duas versões, o que é particularmente importante quando se observa que justamente parte do item (e) - objeto desta tese - não aparece na listagem anterior.
} 
repassar informações necessárias para tal atuação empresarial, resultando, no caso da Rede de Cooperação para a Roteirização da Região Sudeste, em um catálogo de serviços do Caminho Velho (Paraty a Ouro Preto), para utilização pelo mercado para a montagem de roteiros, excluindo-se, portanto, outras ações inicialmente previstas, como (h), (i), (j) e (k).

O Projeto previa as seguintes etapas de execução:

- oficina de planejamento: conduzida pelo consultor planejador, tinha por objetivo repassar o conteúdo das diretrizes operacionais do Programa de Regionalização do Turismo - Roteiros do Brasil, as orientações para elaboração de roteiros turísticos e o planejamento do cronograma das visitas técnicas (etapas seguintes), que deveria estar em conformidade com o estágio em que se encontrava naquele momento o processo de roteirização na região estudada;

- visitas técnicas (sete, no máximo): necessárias para se vivenciar o processo de roteirização em cada macrorregião, poderiam abranger reuniões com atores e lideranças identificadas nos roteiros em estudo, de acordo com o conteúdo abordado e a necessidade identificada;

- oficinas de multiplicação: os agentes multiplicadores, uma vez tendo participado da vivência do processo de roteirização, terão a responsabilidade de disseminar o conhecimento adquirido para os atores do trade turístico e para a comunidade local, por meio de duas oficinas regionais (viabilizadas pelos técnicos do SEBRAE e dos órgãos oficiais de turismo da região em estudo), sem qualquer remuneração por esta atividade; em contrapartida, após a conclusão das 
oficinas regionais, os consultores receberão um certificado de consultor habilitado em roteirização;

- formação da rede digital: ao longo de toda a vivência do processo de roteirização e ao fim deste, deveria ter sido disponibilizada uma rede de comunicação digital entre os participantes por meio de um chat na internet, para favorecer a troca de experiências e esclarecer dúvidas entre os participantes. No entanto, tal rede não chegou a ser formada, pelo menos no caso da Região Sudeste, ocorrendo apenas a divulgação de informações a respeito da logística dos encontros (oficina de planejamento e visitas técnicas) e a comunicação do consultor tutor com o grupo;

- avaliação do processo: o grupo consultivo deverá identificar e estabelecer indicadores de resultado para medir os resultados do Projeto e os gestores locais e estaduais serão responsáveis pelo acompanhamento destes indicadores junto às regiões atendidas através do Sistema GEOR (BRASIL, 2005b, p. 10-11). Vale lembrar que, ao final de cada encontro, os participantes deveriam preencher um formulário de avaliação, cujos resultados, após a tabulação por técnicos do Ministério do Turismo, eram enviados aos participantes.

Convém salientar ainda, a título de complementação, que as despesas para participação dos técnicos dos órgãos oficiais de turismo, dos técnicos do SEBRAE e dos agentes multiplicadores foram cobertas pelo Projeto - os demais 
participantes (técnicos do SENAC e de outras instituições ${ }^{41}$ ) deveriam ter suas despesas pagas pelas respectivas instituições.

A execução e operacionalização do Projeto seria de responsabilidade dos SEBRAE/AC, SEBRAE/DF, SEBRAE/MA, SEBRAE/MG e SEBRAE/RS, em cada macrorregião, respectivamente onde os roteiros seriam implementados.

Ao SEBRAE de cada Unidade da Federação relacionado caberia, também, gerir os recursos financeiros e, com o apoio do consultor tutor, preparar a logística para as oficinas de planejamento e para as visitas técnicas (BRASIL, 2005b, p. 13).

Por fim, convém descrever sucintamente como se deu, efetivamente, tal processo no caso da Região Sudeste, e mais precisamente, no caso do Roteiro Integrado Estrada Real. ${ }^{42}$

\subsection{O Roteiro Integrado Estrada Real}

Como mencionado anteriormente (quadro 17), o Roteiro Integrado Estrada Real foi o escolhido para caracterizar o Programa de Regionalização do Turismo - Roteiros do Brasil na Região Sudeste do país.

Antes de apresentar a descrição deste processo de roteirização, convém apresentar algumas características da região na qual está inserido o roteiro.

\footnotetext{
${ }^{41}$ No caso da Rede de Cooperação Técnica para a Roteirização da Região Sudeste, houve também a participação de docentes do Centro Universitário Salesiano de São Paulo - Unidade de Lorena, em função do envolvimento da instituição com o Roteiro Integrado Estrada Real no Estado de São Paulo.
} 
Conforme descrito pela publicação institucional (INSTITUTO ESTRADA REAL, 2006),

Das picadas abertas pelos índios em suas caminhadas pelo sertão e das áreas desbravadas pelos bandeirantes em busca de metais e pedras preciosas, no final do século XVII, surgem as primeiras trilhas da Capitania das Minas. Com o povoamento de várias áreas auríferas e diamantíferas cresce o comércio de bens de consumo e a exportação, gerando diversificados acessos a essas áreas de produção.

Toda essa exploração comercial entre as principais vilas gerava um intendo contrabando $e$, consequentemente, 0 não pagamento de inúmeras taxas e impostos determinados pelo governo português. Entretanto, para manter o controle desse comércio, a Coroa Portuguesa impôs uma severa legislação que determinava e delimitava caminhos oficiais por onde deveriam circular pessoas, bens e os produtos explorados em território mineiro.

Ao instituir crime de lesa-majestade para aquele que adentrasse ou deixasse as minas gerais sem passar por um dos seus registros de fiscalização e controle, a Coroa Portuguesa pretendia evitar o contrabando e, assim, aumentar os ganhos da Fazenda Real - o que contribuiu para que esses caminhos se tornassem as primeiras estradas oficiais do Brasil (INSTITUTO ESTRADA REAL, [2005?]), conforme descreve o texto a seguir:

São essas vias de acesso da Capitania de São Paulo e do litoral fluminense ao interior da Capitania das Minas que receberam o título de Estrada Real.

\section{$[\ldots]$}

A primeira via a ser oficializada, conhecida como Caminho Velho, ligava a antiga Vila Rica - hoje, cidade de Ouro Preto - ao porto da atual cidade de Paraty, no Rio de Janeiro. Nos últimos anos do século XVII, o governador Arthur de Sá Menezes contratou Garcia Rodrigues Pais para a abertura de uma nova via que ligava a cidade do rio de Janeiro à Vila Rica e ficou conhecida como Caminho Novo. Com a descoberta de diamantes em 1729, na região do Serro Frio, também na Capitania das Minas, ficou delimitado o Caminho dos Diamantes, que partia de Vila Rica rumo ao Arraial do Tejuco, atual cidade de Diamantina. Assim, formou-se a Estrada Real, com seus 1.400 quilômetros.

$[\ldots]$

${ }^{42}$ Do qual este autor participou, como representante do SENAC/SP. 
Esse rico acervo histórico, artístico, folclórico e paisagístico representa um incomensurável potencial turístico ${ }^{43}$. Sua exploração adequada exige um rigoroso processo de planejamento e ordenação turística, com vistas à promoção de um desenvolvimento sustentável.

Diante, pois, das possibilidades de aproveitamento turístico de tão extenso território, no qual "[...] ainda hoje se encontram trilhas calçadas por escravos, pontes, monumentos, ruínas, povoados, distritos e cidades históricas, que preservam um rico patrimônio cultural" e "[...] um relevo peculiar, com lindas aflorações rochosas e uma vegetação típica que confere ao trecho uma diferenciada beleza paisagística" (INSTITUTO ESTRADA REAL, 2006), surgiu, por meio do Instituto Estrada Real, o "[...] maior programa de desenvolvimento turístico em implantação no País".

O Instituto Estrada Real foi o caminho escolhido pela Federação das Indústrias do Estado de Minas Gerais (FIEMG) para proporcionar às comunidades de 177 municípios $^{44}$ a auto-sustentação através do turismo. Ao longo destes quase sete anos, desde sua fundação, em 1999, desenvolveu e executou dezenas de projetos para diagnosticar os potenciais de cada região, melhorar a infra-estrutura turística, sensibilizar as comunidades e atrair turistas, conduzindo as ações sempre atento ao correto aproveitamento do imenso potencial histórico, cultural e natural. A seriedade do trabalho transformou o projeto em Programa Estrada Real, apoiado pelo Ministério do Turismo e escolhido como um dos projetos estruturantes do Governo do Estado de Minas Gerais. O caráter social e de responsabilidade para com o ser humano atraiu grandes agentes da iniciativa privada, que se tornaram parceiros do Instituto Estrada Real, ajudando a viabilizar ainda mais o caminho e gerando divisas para implantação de projetos fundamentais, como a sinalização turística do eixo principal da Estrada Real e das rodovias de acesso, programas de qualificação e o projeto de Produção Associada ao Turismo (INSTITUTO ESTRADA REAL, [2005?]).

Em termos de resultados concretos, o Instituto Estrada Real destaca a repercussão do Programa na mídia nacional e internacional, o que se refletiu em números

\footnotetext{
${ }^{43}$ Grifo nosso.

${ }^{44}$ Sendo 162 municípios em Minas Gerais, oito no Estado do Rio de Janeiro e sete no Estado de São Paulo.
} 
(dados do início de 2005) e demandas por parte de empresas públicas e privadas. Segundo estes dados:

- a Estrada Real ocupou, em 2004, $310.000 \mathrm{~cm}^{2}$ nas páginas de jornais e revistas de grande circulação do país, segundo clipping elaborado pelo Sistema FIEMG;

- o portal da Estrada Real na internet (http: //www.estradareal.org. mesmo ano, cerca de 2.097 .000 visitas;

- a equipe do Instituto Estrada Real participou de diversos eventos, nos quais 799.881 pessoas tiveram contato com a Estrada Real;

- a escola de samba Estação Primeira de Mangueira homenageou a Estrada Real através de seu desfile e de seu samba-enredo no Carnaval do Rio;

- várias empresas têm, de alguma forma, se associado ao programa: a Fiat Automóveis lançou um veículo com a marca Estrada Real, o Fiat Doblò Adventure Estrada Real; a Telemar Norte Leste S.A., por meio da operadora de celulares $\mathrm{Oi}$, traçou um projeto de prioridade em Minas Gerais ao longo da Estrada Real; os Correios lançaram, no dia 27 de setembro de 2005, Dia Internacional do Turismo, uma coleção de selos sobre a Estrada Real iniciativas, estas, que partiram das empresas (MODELO, 2005, p. 8-9).

Como resultado de tal repercussão, tem-se a seguinte situação: Ouro Preto registrou um aumento médio de $20 \%$ no fluxo de turistas, enquanto $15 \%$ a mais de visitantes chegaram a Diamantina e à Serra do Cipó, em torno da qual os meios de hospedagem ampliaram sua capacidade para 1.100 leitos (MODELO, 2005, p. 3). 
Outra ação importante no processo de consolidação da Estrada Real é a implantação de comunicação por sua demarcação e sinalização - a este respeito, o Sr. Eberhard Hans Aichinger, diretor geral do Instituto Estrada Real, afirma:

[...] A Estrada Real está praticamente toda demarcada. Nós começamos o trabalho por Diamantina e fomos descendo até Paraty, no Rio de Janeiro; e da cidade do Rio de Janeiro fomos até Ouro Preto. A sinalização do caminho está sendo feita por meio da colocação de marcos da Estrada Real, viabilizados pela iniciativa privada, pelas prefeituras e pelo Ministério do Turismo [...]" (FÉLIX, 2005, p. 9-10).

Em paralelo às ações supramencionadas, iniciou-se a formação da Rede de Cooperação Técnica para a Roteirização que, na região Sudeste, contemplou o Roteiro Integrado Estrada Real. Este processo iniciou-se em setembro de 2005, quando foi realizada em Paraty/RJ, uma oficina de planejamento que contou com a presença de representantes do Ministério do Turismo e do SEBRAE Nacional, bem como das entidades envolvidas (órgãos oficiais estaduais de turismo, SEBRAE, SENAC, Centro Universitário Salesiano de São Paulo - Unidade de Lorena ${ }^{45}$ e dos agentes multiplicadores selecionados conforme descrito anteriormente.

Neste encontro, no qual foram realizadas apresentações para nivelar o entendimento dos participantes sobre o Programa de Regionalização do Turismo Roteiros do Brasil, a Rede de Cooperação para a Roteirização e sobre o Roteiro Integrado Estrada Real, os trabalhos foram conduzidos pela consultora e planejadora Isabel Castro, que se utilizou de técnicas de moderação e visualização de idéias para o planejamento participativo em grupo, e pelo consultor tutor Flávio

\footnotetext{
${ }^{45}$ Embora o Roteiro Integrado Estrada Real não contemple o Estado do Espírito Santo, técnicos do órgão oficial de turismo, do SEBRAE/ES e do SENAC/ES estiveram presentes nos encontros da Rede.
} 
Vitarelli, responsável pela condução das questões técnicas de elaboração de roteiros, bem como pela elaboração da metodologia de roteirização a ser utilizada.

Na ocasião, o Sr. Flávio Vitarelli abordou os seguintes assuntos:

- a composição do Caminho Velho da Estrada Real, que liga Paraty a Ouro Preto;

- a ausência de engajamento governamental do Estado de São Paulo no projeto até aquele momento;

- a necessidade da tematização para a estruturação de roteiros turísticos;

- os temas possíveis de serem trabalhados no Caminho Velho;

- as características e os marcos referenciais dos municípios pertencentes ao Caminho Velho;

- a tipologia dos roteiros (programados ou espontâneos) e as possibilidades de realização dos roteiros por caminhantes ou utilizando-se bicicletas, cavalos e automóveis;

- uma pesquisa de demanda realizada em 2004 pelo Instituto Estrada Real e tabulada pelo SEBRAE/MG através de entrevistas e da aplicação de questionários junto a 32 agências (sendo dez operadoras turísticas, quinze agências de viagens e sete agências receptivas) dos municípios de São Paulo, Rio de Janeiro e Belo Horizonte, a fim de se identificar o interesse e a forma das agências em operar roteiros no Caminho Velho; esta pesquisa foi atualizada em 2005, quando uma nova consulta foi feita a dezesseis operadoras e/ou agências receptivas, ressaltando o forte interesse das empresas consultadas em trabalhar com o roteiro em questão; 
- a elaboração de um banco de dados que seriam coletados pelos participantes da Rede; este banco de dados deveria contemplar os serviços de hospedagem, alimentação, receptivo, as atividades que podem ser praticadas (e não os atrativos) e os serviços de suporte aos meios de transportes (não deve ser dada maior importância aos eventos, em função da pouca utilidade destes para a formatação de roteiros) a partir de uma proposta preliminar de formato para a coleta de dados.

O consultor tutor apresentou detalhadamente a metodologia de trabalho a ser adotada, ou seja, as etapas do processo que seriam os temas das visitas técnicas que ocorreriam até o término do projeto, salientando que se tratava de um processo ainda em construção, sujeito a alterações:

- prospecção e pesquisa;

- análise da oferta/banco de dados;

- formatação de roteiros;

- promoção e comercialização e,

- validação metodológica.

Os demais encontros, chamados de visitas técnicas, foram conduzidos apenas pelo consultor tutor ${ }^{46}$ e realizaram-se em outros municípios espalhados ao longo da Estrada Real, para que fosse possível aos participantes tomar contato com o roteiro em questão e avaliar as possibilidades de concretização do roteiro, assim

\footnotetext{
${ }^{46}$ A consultora planejadora Isabel Castro teve apenas uma pequena participação na última visita técnica, em Ouro Preto/MG.
} 
como as dificuldades de sua viabilização. Desta forma, realizaram-se quatro visitas técnicas até maio de 2006:

- Itamonte/MG - novembro de 2005;

- Guaratinguetá/SP - fevereiro de 2006;

- Tiradentes - março de 2006;

- Ouro Preto - maio de 2006.

A primeira visita técnica iniciou-se com uma exposição do consultor tutor do projeto sobre a busca de experiências que pudessem auxiliar no seu encaminhamento, e a proposta adotada esteve baseada no projeto "Veredas", um curso superior à distância da Universidade Federal de Minas Gerais (UFMG) para formação de professores, estruturado pedagogicamente em três etapas: ação, reflexão e ação ressignificada. Em seguida, o consultor relatou os procedimentos seguidos e as dificuldades encontradas para a realização do banco de dados:

- em conjunto com o Instituto Estrada Real, o formato do banco de dados foi estruturado, junto com um manual de orientações para o seu preenchimento;

- este banco de dados deve ter um caráter comercial (e não institucional), havendo, portanto, uma grande necessidade de responsabilidade na sua elaboração e de qualidade no resultado final;

- uma vez selecionados os treze municípios principais do Caminho Velho, estes foram distribuídos entre os parceiros de Minas Gerais para a coleta de dados (utilizando-se diversas fontes), que se deu de forma diferente segundo cada parceiro e resultou em um material incompleto, com $50 \%$ dos dados coletados; 
- em São Paulo, o órgão estadual de turismo contatou as prefeituras dos municípios envolvidos para o preenchimento do arquivo (Microsoft Access) iniciativa valorizada pelo consultor, que resultou na mobilização dos agentes públicos - todavia, o resultado final também foi insatisfatório e, diante disto, o SEBRAE de Guaratinguetá e o Centro Universitário Salesiano - Unidade de Lorena, assumiram a responsabilidade de revisar o banco de dados, que abrangeria os municípios de Cruzeiro, Lorena, Guaratinguetá e Cunha, considerados pólos de turismo receptivo (os municípios de Silveiras, Areias e Cachoeira Paulista devem ser vistos como locais para a prática de atividades);

- os representantes de Paraty/RJ disponibilizaram algumas informações solicitadas no encontro anterior, mas não conseguiram desenvolver o banco de dados uma vez que, por dificuldades de comunicação, a rede não funcionou em Paraty;

- a inclusão, no banco de dados, dos municípios de Rio de Janeiro e Belo Horizonte (como principais bases emissoras de turistas para a região) será ainda avaliada;

- o banco de dados seria devolvido padronizado (em arquivo digital) para complementação e, a partir deste momento, a pesquisa não deveria mais ser feita em fontes secundárias, mas sim por telefone ou pessoalmente;

- a seleção dos estabelecimentos que fariam parte do banco de dados deveria basear-se no bom senso e na indicação de outras fontes (associações comerciais, por exemplo), tendo em vista as condições mínimas para utilização

- de qualquer forma, quem vai selecionar os equipamentos para uso é o mercado; 
- o banco de dados, uma vez finalizado, não será disponibilizado ao grande público (usuários finais - turistas), uma vez que ele trará informações de acesso restrito pelo trade (sobre preços, por exemplo), e será atualizado periodicamente pelo Instituto Estrada Real.

Através de contatos com a rede comercial (operadoras e agências de receptivo), o consultor identificou a necessidade e o interesse por produtos de menor duração (meio dia e/ou dia inteiro) para as agências de receptivo da região e salientou, ainda, que o foco do projeto é o mercado nacional e internacional (e não regional), para a rede comercial (e não para o turismo espontâneo/auto-guiado); por fim, mencionou a importância da inclusão dos municípios paulistas (reforçada pela apresentação de fotos da região) e a assertividade do apelo comercial estabelecido e do grande recorte escolhido, que representa uma forte identidade e diversidade para a roteirização.

A segunda visita técnica iniciou-se com a apresentação, pelo consultor tutor, de informações atualizadas do processo de roteirização e comentou que a roteirização deveria ser a marca do atual Governo Federal na área do turismo e que a BRAZTOA passou a fazer parte da Rede como um novo parceiro. Segundo o consultor, esta segunda visita teria por objetivo central a necessidade de fortalecer o processo de rede, uma vez que a etapa anterior foi concluída com êxito, com o banco de dados completo.

Com relação ao envolvimento dos fornecedores locais, o Sr. Flávio Vitarelli comentou que estava visitando os agentes receptivos da região e que os demais 
fornecedores deverão ser contatados por carta e/ou através de reuniões; definiuse, ainda, que a necessidade deve concentrar-se no fortalecimento das agências receptivas existentes (e não no fomento à abertura de novas agências), uma vez que as agências de turismo receptivo analisadas até então são de pequeno porte e de fraca atuação. Outras informações fornecidas:

- definiu-se que o consultor tutor não vai criar os roteiros, pois isto é papel dos operadores, mas sim entregar as informações para o mercado;

- o consultor orientador, Sr. Mário Petrocchi, não fazia mais parte do projeto, pois seu contrato venceu e não foi renovado e

- o "produto Estrada Real" estaria inserido no Salão do Turismo nos stands da macrorregião Sudeste.

A partir desta segunda visita técnica, criou-se um momento dentro da programação do evento, para a apresentação de casos de roteirização, que ocorreu na parte da tarde desta segunda visita. Os casos apresentados foram:

- Rota do Sol e da Moqueca (ES);

- Rota 040 (RJ);

- Produção Associada ao Turismo;

- Circuito dos Fortes e Caminhos de Anchieta (SP).

Abordou-se, ainda, a questão da formatação de roteiros, relembrando que o banco de dados tem um caráter comercial, razão pela qual houve a necessidade de uma adequada seleção dos equipamentos nele incluídos. O consultor apresentou 
algumas propostas de roteiro para pedestres, compreendendo 38 localidades dos três estados e alguns quadros com informações sobre:

- as localidades abrangidas pelo Caminho Velho da Estrada Real, seus atrativos âncoras e respectivos segmentos para os mercados internacional, nacional e regional;

- as demandas regionais por localidade;

- as atividades culturais, religiosas, de compras e de natureza possíveis de realização por localidade;

- os problemas das localidades.

Em relação a esta apresentação, merecem destaque os problemas dos municípios paulistas do trecho analisado pelo consultor:

- Cruzeiro: guias, urbanismo e conservação do patrimônio ferroviário;

- Lorena: urbanismo e falta de atratividade;

- Guaratinguetá: urbanismo e falta de atratividade;

- Cunha: guias de turismo, urbanismo, atividades de natureza e segurança (na ligação Cunha-Paraty).

Em todas as visitas técnicas, realizaram-se algumas visitas de campo com a finalidade de proporcionar aos integrantes da Rede uma maior familiarização com o produto que se estava sendo proposto. 
Durante o encontro realizado em Guaratinguetá/SP, o grupo dirigiu-se a Cunha, para visita técnica noturna à Secretaria de Turismo de Cunha, aos ateliês de cerâmica do município e para jantar e, no terceiro dia da visita técnica, foi realizada uma visita de campo para Silveiras (para conhecimento do artesanato local) e Areias - municípios que, embora não estejam no eixo principal da Estrada Real, apresentam atrativos e atividades que podem ser contemplados no processo de roteirização da região. ${ }^{47}$ No início da terceira visita técnica, o consultor esclareceu, a respeito da situação do processo de roteirização, que a Rede vai dar os instrumentos para a roteirização e que o consultor não vai criar roteiros, como já havia sido definido anteriormente, a fim de evitar uma confusão de papéis com os agentes de viagens/operadores/receptivos. Em relação à promoção e comercialização (foco desta visita técnica), os temas colocados para discussão foram os seguintes:

- elaboração do catálogo de serviços;

- ações de parcerias;

- famtur e fampress e

- participação em feiras e eventos.

O consultor apresentou uma versão preliminar do catálogo de serviços, que foi criado a partir de consultas a um designer, ao Plano Aquarela (EMBRATUR) e ao Instituto Estrada Real e solicitou que os participantes, divididos em grupos por

\footnotetext{
47 Os comentários sobre as visitas de campo realizadas durante as visitas técnicas da Rede de Cooperação para a Roteirização da Região Sudeste restringir-se-ão aos municípios paulistas visitados, uma vez que é este o foco deste trabalho.
} 
Estados, fizessem uma rápida revisão do material e fizessem críticas e sugestões para a versão final.

O último dia da visita caracterizou-se por apresentações do Flávio Vitarelli sobre:

- diferenciação entre rota e roteiro;

- cadeia produtiva;

- mapas para visualização dos mercados regionais;

- retrospectiva dos temas abordados nas visitas anteriores;

- Circuito das Águas/MG e

- FAMTUR.

Especificamente quanto ao FAMTUR, foi apresentada uma proposta de roteiro para cobrir uma "lacuna" quanto à roteirização - como havia esta expectativa em relação à elaboração de um roteiro e, diante da dificuldade de se definir um público-alvo específico (condição necessária para a elaboração de roteiros), o consultor apresentou três propostas de FAMTUR do roteiro Paraty-Ouro Preto, de 5, 8 e 14 dias de duração, gerando várias discussões sobre a sua operacionalização.

Iniciando os trabalhos de apresentação e discussão dos resultados obtidos (foco da última visita, realizada em Ouro Preto), o consultor tutor Flávio Vitarelli, relembrou que a metodologia adotada, já utilizada em outros lugares anteriormente e adaptada ao recorte escolhido, seria aplicada em outros territórios que já estão sendo trabalhados pelos parceiros da Rede, inclusive fora do Caminho Velho, em 
dez ações de multiplicação para toda a Região Sudeste que deveriam ser viabilizadas financeiramente pelos parceiros atuantes nos territórios escolhidos.

O consultor lembrou, ainda, que os agentes multiplicadores não atuarão como consultores de roteirização, visto que a função deles é multiplicar a metodologia com vistas à sensibilização dos participantes.

Com relação ao catálogo de serviços discutido na visita técnica anterior, foi entregue aos presentes uma versão preliminar do catálogo, contendo apenas os textos que farão parte do documento definitivo, pois o consultor informou que 0 material foi passado para a agência de publicidade que cuida da comunicação do Instituto Estrada Real, que não entregou a versão final do catálogo pronto a tempo da reunião.

Outros documentos entregues aos participantes foram o detalhamento da metodologia adotada pelo consultor tutor e um diagnóstico do processo de roteirização elaborado por Flávio Vitarelli, que contém vários documentos encaminhados e/ou entregues anteriormente em outros encontros, como a lista dos participantes da Rede, as tabelas de sistematização da rota (com informações coletadas através do processo de elaboração do banco de dados e das visitas técnicas realizadas pelo consultor), as sugestões de roteiros, os papéis dos parceiros, os encaminhamentos para a continuidade do Projeto, as sugestões de locais para multiplicação da metodologia nos Estados de Minas Gerais e São Paulo, as propostas de novos roteiros interestaduais integrados, as viagens 
realizadas pelo consultor tutor e os encontros realizados com os fornecedores do Caminho Velho.

Na parte da tarde, a condução dos trabalhos ficou a cargo consultora planejadora Isabel Castro que, após realizar uma revisão do processo de roteirização, propôs uma discussão em grupo com o uso de técnicas de visualização e moderação sobre:

- a avaliação do processo de rede (pontos positivos e negativos e propostas de melhoria) e

- propostas para sustentabilidade e continuidade da Rede.

Ao final dos trabalhos, a até então responsável pela coordenação nacional da Rede, Daniela Bitencourt, comunicou que não mais faz parte do quadro do SEBRAE Nacional, passando a atuar junto ao Instituto Marca Brasil e que reconhece que, embora o projeto esteja sujeito a críticas, é inegável a importância da sua continuidade - o que será transmitido ao SEBRAE Nacional - assim como o trabalho e a participação dos envolvidos.

Em relação à multiplicação, a representante do Instituto Marca Brasil ressaltou a necessidade dos territórios terem condições de absorver os custos das ações e disse que esta discussão deverá ser centralizada pelo Ministério do Turismo. Quanto ao Salão do Turismo, ela informou que o SEBRAE Nacional e o Ministério do Turismo confeccionarão um material promocional das cinco Redes de Cooperação e da Estrada Real, que haveria uma apresentação dos destinos da 
Rede no Núcleo de Conhecimento e que a Estrada Real ficaria no estande do Estado de Minas Gerais. Foi informado, ainda, que o balcão da Belotur (órgão de turismo do município de Belo Horizonte) seria dividido para abrigar a Rede de Cooperação da Região Sudeste.

Tais informações geraram sérias discussões entre os participantes, devido ao descontentamento com a exclusão da Rede no momento de definição da inserção da Rede e da Estrada Real no Salão do Turismo - uma das principais preocupações quando do início do processo de Rede - e com as mudanças referentes a este assunto em relação ao que havia sido comentado em encontros anteriores.

Convém salientar que o órgão oficial de turismo do Estado de São Paulo não encaminhou nenhum representante a esta última visita técnica - o que evidenciou a pouca importância do Estado no processo, acentuada pela polêmica participação do Estado nas definições relativas ao Salão do Turismo (comentada durante este momento final de discussão).

Outra informação relevante é que ocorreu uma reunião com representantes do SEBRAE dos Estados envolvidos e do SEBRAE Nacional nos dias que antecederam esta visita técnica, na qual se decidiu que, quanto ao Estado de São Paulo, outros municípios (além daqueles situados no eixo principal do Caminho Velho) deverão ser inseridos no âmbito da Estrada Real por meio da importância da cultura e da história do café que perpassa a área de abrangência da Estrada 
Real - o que pode representar maiores oportunidades de atuação do SENAC/SP no desenvolvimento turístico da região.

A este respeito, deve ser realizada uma reunião em breve na região, para discutir detalhes da expansão destes trabalhos, da qual devem participar os representantes das instituições paulistas participantes da Rede de Cooperação Técnica para Roteirização (SEBRAE, SENAC, Secretaria Estadual de Turismo e UNISAL). Observa-se, portanto, que podem derivar destas novas articulações voltadas para o desenvolvimento do turismo na região importantes oportunidades de desenvolvimento para a área de turismo.

\subsection{Os municípios de Guaratinguetá e Cunha/SP: justificativa da escolha dos municípios-objetos de estudo, contextualização regional e caracterização histórico-geográfica particularizada}

Em função da participação do autor na Rede de Cooperação Técnica da Região Sudeste e, portanto, do acesso às informações acerca dos municípios definidos pelo consultor tutor do Roteiro Integrado Estrada Real para o foco do trabalho de roteirização no Caminho Velho (de Paraty a Ouro Preto), optou-se por conciliar a disponibilidade de dados à necessidade de se definir municípios nos quais o instrumento proposto a seguir seria testado - soma-se a isto o fato de o Vale do Paraíba ser, efetivamente, uma região de intensa e reconhecida procura turística (maior em alguns municípios, menor em outros, evidentemente, de acordo com suas características).

De acordo com a metodologia de roteirização proposta pelo consultor tutor, em função do grande recorte escolhido para esta primeira experiência de roteirização, 
compreendendo um grande número de municípios de três Estados (Rio de Janeiro, São Paulo e Minas Gerais), definiu-se que, inicialmente, seriam levantadas as informações apenas dos municípios localizados sobre o eixo principal da Estrada Real, desconsiderando-se os demais e que, mais especificamente, a atenção deveria focar-se nas localidades que apresentassem possibilidades de realização de atividades turísticas de visitação e/ou estruturas receptivas propícias à comercialização turística por meio de roteiros, razão pela qual o município de Cachoeira Paulista/SP não fez parte dos trabalhos iniciais de formação do banco de dados para a roteirização. ${ }^{48}$

Assim, inicialmente, pensou-se em trabalhar com os quatro municípios do trecho paulista do eixo principal da Estrada Real pesquisados para a formação de um banco de dados para a roteirização: Cruzeiro, Lorena, Guaratinguetá e Cunha.

Todavia, dadas condições de ordem pessoal e profissional do autor para a realização deste trabalho e a importância e efetividade da atividade turística nos municípios supramencionados, optou-se por delimitar a aplicação do instrumento ora proposto nos dois últimos municípios mencionados ${ }^{49}$, cuja caracterização será apresentada a seguir, após uma breve contextualização regional do Vale do Paraíba, no qual estão inseridos geograficamente.

\footnotetext{
${ }^{48}$ Vale lembrar, também, que para fins deste estudo, não haveria possibilidade de aplicação do instrumento proposto para o município de Cachoeira Paulista/SP, dadas as características do turismo que lá se desenvolve, praticamente voltado apenas para o aspecto religioso - com características diferentes, todavia, daquele existente em Guaratinguetá e Aparecida, ambos no Vale do Paraíba.

${ }^{49}$ Os dados coletados sobre os municípios de Guaratinguetá e Cunha/SP encontram-se no anexo I desta tese.
} 


\subsubsection{O Vale do Paraíba}

Antes de iniciar a caracterização particularizada das localidades estudadas, convém contextualizá-las em termos históricos e geográficos, dentro do âmbito regional, uma vez que é, inclusive, a partir da abordagem turística da regionalização que tais municípios se relacionam e, para tal contextualização, recorreu-se à obra de Müller (1969), considerada fundamental ${ }^{50}$ para o entendimento da região na qual se encontram os municípios de Guaratinguetá e Cunha.

A autora, no prefácio da referida obra (MÜLLER, 1969, p. X), explica que, apesar de todos os atrativos que o estudo monográfico pode oferecer, como o da limitação do campo de estudo e o da segurança de uma metodologia bem estabelecida, optou pela focalização do fato urbano em base regional, que deve concentrar-se em análises comparativas, na vida de relações e na organização do espaço que dela decorre, por julgar o tema de maior interesse e com maiores possibilidades de chegar a sugestões de ordem prática.

E várias foram as razões para a escolha do Vale do Paraíba como objeto de estudo, a saber: a intensidade e a importância da urbanização da área, sua localização (entre duas metrópoles, São Paulo e Rio de Janeiro) e a inegável individualidade geográfica da região.

Ao descrever as paisagens urbanas do Vale do Paraíba, a autora tenta partir de uma visão sintética da geomorfologia da região e sua gênese para caracterizar o 
relevo e, assim, ter melhor base para justificar as condições para a implantação das cidades, constituindo-se em ponto de partida para a apresentação dos vários sítios urbanos - visão aqui apresentada a fim de contribuir para o entendimento da configuração da região. A autora aponta que

[...] O Vale do Paraíba está integrado numa das grandes regiões naturais, a do chamado Planalto Atlântico, em que constitui unidade característica. Grande parte de sua individualidade deriva do relevo, cujas linhas mestras seguem marcante paralelismo em relação à linha da costa; de fato, um simples olhar em esquema topográfico é suficiente para se perceber que, com exceção do maciço da Bocaina, que ocupa a porção NE da região, o relevo, basicamente, é representado por uma série de cristas e de vales dispostos na mesma direção, SO-NE. Esses alinhamentos básicos do relevo, de acordo com a maioria dos geomorfólogos e geógrafos que estudaram a região, foram estabelecidos por fenômenos de tectonismo, efetuado em vários ciclos. O primeiro, de maior amplitude, seria o responsável pela gênese das principais elevações (Serra do Mar e Serra da Mantiqueira), bem como pelo isolamento do maciço da Bocaina; falhamentos posteriores, criando soleiras tectônicas, teriam provocado a formação da bacia de Taubaté, de sedimentação flúvio-lacustre. A seguir, essas superfícies foram modeladas, desdobrando-se em níveis de erosão que, embora apoiados nas linhas mestras do relevo, vieram dar maior complexidade ao conjunto e multiplicar as possibilidades de aproveitamento pelo homem (MÜLLER, 1969, p. 223-224).

A região do Vale do Paraíba se identifica como unidade fisiográfica no conjunto do Planalto Atlântico e apresenta algumas subdivisões naturais:

- vale médio superior: vai do célebre "cotovelo"51, à altura de Guararema, até Cachoeira Paulista; se apresenta como um "corredor"52 que sempre funcionou como via natural de passagem, uma extensa e larga depressão franqueada ao norte pela Mantiqueira e ao sul pelas elevações que servem de divisores de

\footnotetext{
${ }^{50}$ Segundo depoimento do Prof. José Luiz Pasin, do Instituto de Estudos Valeparaibanos (IEV).

${ }^{51}$ Entre aspas, no original.

52 Entre aspas, no original.
} 
águas com o curso superior, tais como as Serras de Quebra Cangalha e de Jambeiro;

- vale médio inferior: se prolonga até o Estado do Rio de Janeiro, abrangendo as cidades à jusante de Cachoeira Paulista (Cruzeiro, Lavrinhas, Queluz), bem como as situadas em área drenada para esse trecho da bacia do Paraíba (Silveiras, Areias, São José do Barreiro e Bananal); constituída por terrenos cristalinos bastante trabalhados por erosão epicíclica na qual pode-se distinguir duas porções, uma correspondendo à soleira da bacia de Taubaté, que vai de Cachoeira Paulista até a fronteira interestadual, à altura de Queluz, e outra que, acompanhando o sopé do maciço da Bocaina, se projeta para leste, indo de Silveiras a Bananal;

- vale superior ou Alto Paraíba: desenvolve-se das nascentes até Guararema, quando o rio abandona sua direção inicial (NE-SO) para, numa inflexão de $180^{\circ}$, tomar sentido oposto (SO-NE); de forma geral de relevo movimentado, admite subdivisão em duas porções: uma mais meridional (que poderia ser chamada de Planalto do Paraitinga) e o maciço da Bocaina (MÜLLER, 1969, p. 226-231).

Após analisar a configuração dos núcleos urbanos e a urbanização da região compreendida pela bacia do rio Paraíba na década de 60 (abordagem que será, aqui, desconsiderada, devido à desatualização dos dados), subdividida em duas zonas, a região do Médio Paraíba (área mais intensamente urbanizada, que contava em 1965 com 95,8\% do total da população urbana regional) e a do Alto Paraíba (MÜLLER, 1969, p. 3), a autora descreve e analisa o processo de urbanização da região, o que contribui para entender historicamente a sua 
formação nos períodos do devassamento (século XVII), durante o "ciclo do ouro" (século XVIII) e o "ciclo do café" (século XIX), chegando-se à industrialização (século XX).

Müller (1969, p. 13) lembra que "a conquista do Vale do Paraíba teve início em fins da primeira metade do século XVII, como parte do processo de expansão ecológica dos habitantes da área 'core' da Província, desenvolvida em torno de São Paulo de Piratininga" - processo, este, que parece ligar-se aos seguintes fatores principais: a política metropolitana de promover a ocupação de territórios através da doação de terras; a procura de jazidas minerais e, como substitutivo provisório, de preamento de índios; e o interesse em estabelecer ligações com o litoral norte da Província.

Assim, a primeira sesmaria concedida na região (em 1628, por D. Mariana de Souza da Guerra, condessa de Vimieiro e donatária da Capitania de São Vicente), localizada entre as atuais cidades de Pindamonhangaba e Taubaté, representou o passo inicial para a conquista do Vale do Paraíba, resultando na transformação de Taubaté em "[...] verdadeiro centro de irradiação de povoamento [...]" para jusante (MÜLLER, 1969, p. 14), o que parece explicar, também, o surgimento dos futuros municípios de Guaratinguetá ${ }^{33}$, Pindamonhangaba (p. 15) e Tremembé (p. 16).

Paralelamente, a montante, efetuavam-se outros movimentos de colonização, como aquele partindo da vila de Mogi das Cruzes, que deu origem à fundação de Jacareí (p. 17) e ao aldeamento de Nossa Senhora da Escada, atual Guararema

\footnotetext{
${ }^{53}$ A história de Guaratinguetá será abordada mais detalhadamente no capítulo 2.3.2.
} 
(p. 18). Por fim, cabe aqui referência a outro núcleo seiscentista, a Aldeia de São

José, considerado o embrião da cidade de São José dos Campos (p. 18-19).

Feito um balanço geral, verifica-se que o século XVII se encerra com saldo de três vilas (Taubaté, Jacareí e Guaratinguetá), dois povoados ligados a patrimônios religiosos (Pindamonhangaba e Tremembé) e dois aldeamentos indígenas (N. Sra. da Escada e São José). Observa-se que os núcleos seiscentistas estão limitados ao vale médio superior do Paraíba, desde seu início, onde se fazia a travessia do rio, em N. Sra. da Escada e Jacareí, até o ponto em que a bacia de Taubaté é estrangulada por esporões cristalinos, à altura de Guaratinguetá: é uma tomada de posse, que, correspondendo a ampla via natural de passagem e usufruindo da posição geográfica da região, se projetava como uma cunha em direção NE e se instalava como área de ligação entre o território mineiro e a linha litorânea, fatos que, no período seguinte, seriam de grande significação (MÜLLER, 1969, p. 19).

A autora refere-se, no final da citação acima, à descoberta das Minas Gerais dos

Cataguás, que significaria uma nova etapa na história da ocupação e da urbanização do Vale do Paraíba.

A situação geográfica da região, dando-lhe contigüidade em relação às áreas de mineração, de que é separada pela Serra da Mantiqueira, que não constitui barreira intransponível, fez com que o Vale do Paraíba se transformasse na principal área paulista de abastecimento das Minas Gerais, por ela passando ou dela saindo os mais variados produtos [...]. Intensificando-se o povoamento, sua economia, embora ainda policultora, já escapava aos limites da mais estrita subsistência, que vigorara anteriormente. [...]

Como via de passagem, transformado em área abastecedora das Minas Gerais, o Vale do Paraíba irá, no século XVIII, ter sua vida cada vez mais condicionada pelas vias de circulação. Enquanto o curso médio, como amplo "corredor" de acesso, ganha importância, as ligações entre as áreas mineradoras e o litoral provocarão o aparecimento de vias transversais, trazendo novas possibilidades à ocupação e povoamento da região (MÜLLER, 1969, p. 20).

É neste contexto que se assiste ao surgimento do povoado de Caçapava, em 1705

(MÜLLER, 1969, p. 20) e Lorena, cujo nascimento apresenta maior significação por 
estar ligado ao desenvolvimento da primeira via transversal (p. 21) - estas vias, importantes por propiciar o início da urbanização fora do caminho geral de circulação do vale médio do Paraíba, decalcavam-se, parcialmente, em trilhas já usadas pelos indígenas:

Enquanto o caminho para Minas, pela garganta do Embaú, correspondia a velha trilha guainá, as que buscavam o litoral unindo as atuais cidades de Taubaté e Itatuba ${ }^{54}$ e de São José dos Campos e Caraguatatuba, seguiam velhos roteiros dos tamoios. Dessas ligações resultariam, na rota de Minas, o aparecimento de Cachoeira Paulista e, mais para o litoral, o de Cunha $^{55}$, São Luís do Paraitinga e Paraibuna (MÜLLER, 1969, p. 22).

Pouco tempo depois do surgimento de Cunha, São Luís do Paraitinga (originada a partir da concessão de sesmarias em 1688 e elevada a vila em 1773) e Paraibuna (cuja origem se prende a São Luís do Paraitinga), nasceu o povoado de Bocaina, mais tarde, Cachoeira Paulista, a partir de um aglomerado de choupanas de pescadores onde, em 1780, alguns devotos do S. Bom Jesus the erigiram capela (MÜLLER, 1969, p. 22-23).

No caminho para a Mantiqueira outro núcleo se originou em 1781, onde foi erigida a capela a Nossa Senhora da Conceição do Embaú, que seria elemento aglutinador de um povoado, ao qual estaria ligada, em sua origem a atual cidade de Cruzeiro (MÜLLER, 1969, p. 24).

\footnotetext{
${ }^{54}$ Embora o texto apresente o nome "Itatuba", acredita-se que a autora estivesse referindo-se a Ubatuba, seja pelo fato de, geograficamente, existir tal ligação, seja pela existência de menção, em outra passagem do texto, à fundação de "[...] povoação entre Taubaté e Ubatuba" (MÜLLER, 1969, p.23) seja pelo fato do único município brasileiro existente com tal nome estar localizado no Estado da Paraíba.

${ }^{55}$ A história de Cunha será abordada mais detalhadamente no capítulo 2.3.3.
} 
Finalmente, entre os caminhos que condicionaram o aparecimento de novos núcleos de povoamento, há, ainda, o chamado "caminho novo da Freguesia da Piedade", que, partindo de Lorena, buscava o Rio de Janeiro. Surgira ele como conseqüência imediata da descoberta das minas de Cuiabá e Goiás, com a intenção de evitar, como pretendia o primeiro capitão-general de Minas, que por esta Província se fizesse a ligação das novas áreas de mineração com a Capital. Atendendo aos interesses paulistas, foi aberta a estrada partindo de Lorena visando estabelecer comunicação terrestre com o Rio de Janeiro, e contrariando os interesses de Parati e Angra dos Reis, os antigos elos de ligação por via marítima [...]. Apesar de sucessivas provisões reais no sentido de que todo apoio fosse dado à iniciativa da abertura da estrada, a oposição somada dos fluminense e dos jesuítas, estes proprietários da Fazenda Santa Cruz, que deveria ser atravessada pela nova via, a que se acrescentou a crise criada com a extinção da Capitania de São Paulo (1748-1765), fizeram com que o caminho fosse progredindo muito lentamente, a ponto de, só em 1770, chegar a ter trânsito regular. Apesar de tudo, ofereceu ele atrativos suficientes à fixação do povoamento, desenvolvendo-se, às suas margens, dois aglomerados, Areias e Bananal (MÜLLER, 1969, p. 24).

Segundo Müller (1969, p. 25), o único povoado surgido neste período sem ligação direta com o surgimento das vias de circulação é Aparecida, cuja origem está ligada ao encontro da imagem de Nossa Senhora em 1717, nas águas do rio Paraíba, por três pescadores: "a imagem, logo considerada miraculosa, foi colocada em capela própria, em 1743, e, em torno dela, foi-se desenvolvendo o povoado que, hoje, é a cidade que abriga a Basílica da Padroeira do Brasil”.

Com a criação de dez novos núcleos, entre os quais três chegaram a vila (Lorena, São Luís do Paraitinga e Cunha), e sete se mantiveram como povoados, o século XVIII assistiu, ainda, ao desenvolvimento de aglomerados de origem seiscentista. Assim, Pindamonhangaba ascende a vila, em 1705, e São José dos Campos, em 1767, dando à região, até o fim do período, um acervo de oito vilas, uma freguesia e oito povoados (MÜLLER, 1969, p. 25).

A autora lembra também que, embora a origem dos núcleos setecentistas esteja ligada a patrimônios religiosos, a povoações espontâneas ou não, é evidente que, possivelmente com exceção de Aparecida, todos estiveram diretamente ligados às 
vias de circulação (sempre intensamente percorridas), sejam aquelas relacionadas

à ligação com Parati (para posterior acesso via marítima com o Rio de Janeiro), sejam para as ligações com Minas Gerais, apesar da péssima qualidade e da difícil manutenção destas vias - o mesmo valendo para as vias transversais (MÜLLER, 1969, p. 25-26).

De forma geral, deve-se considerar que a evolução da urbanização do Vale do Paraíba na segunda metade do século XVII e no século XVIII, está intimamente presa, como não poderia deixar de ser, à própria marcha da história de São Paulo, representando, também, no entanto, pela posição geográfica da região, "um capítulo decisivo da história, ou pelo menos da pré-história de Minas Gerais" (HOLANDA, 1964, p. 110). Tudo aí se prende à circulação para as áreas mineradoras, primeiro, como via de penetração, depois, como passagem obrigatória de ligação; a vida econômica refletia, diretamente, as condições criadas pela relações com Minas, mais especialmente no século XVIII. Assim, na primeira parte deste século, o Vale do Paraíba se transforma em verdadeira área subsidiária dos sertões mineiros, o meio rural produzindo para seu abastecimento e os núcleos urbanos fornecendo-lhes mão-deobra [...]. Se, de um lado, as vilas e povoações se desfalcaram de população, em conseqüência da atração das minas, de outro, as áreas rurais se povoaram, pela intensificação da procura de terras para a lavoura; no final, lucraram também os núcleos urbanos, já que havia mais a quem atender, tanto no meio rural quanto nas Minas. Assim, apesar de na segunda metade do século XVIII ir o Vale do Paraíba perdendo, gradativamente, seu papel de área abastecedora das Minas, pelo crescente equipamento desta região e pela concorrência do Rio de Janeiro, os centros urbanos puderam acusar algum desenvolvimento, mesmo que modesto, graças ao lastro econômico deixado pela primeira metade de século e ao afluxo das populações rurais, que já não encontravam na produção agrícola a mesma motivação. Criou-se, então, uma situação de desequilíbrio, com florescimento de núcleos urbanos, que, no entanto, não encontravam forma de poder desenvolver sua economia e suas atividades ou de melhor se equipararem para atender à sua população e à das áreas vizinhas. No último quartel do século XVIII, o "nenhum modo de ganhar a vida" (PRADO, 1934, p. 146) das povoações fazia com que todas se ressentissem da falta de infraestrutura econômica, situação que iria perdurar até que, no final do século, um novo elemento viria fornecer-Ihes, com juros, o tão necessário elemento de progresso - o café" (MÜLLER, 1969, p. 28-29).

Segundo a autora (MÜLLER, 1969, p. 29-30), embora existam divergências quanto à data e ao local de introdução da cafeicultura no Estado de São Paulo, não há 
dúvida que o Vale do Paraíba se insere na fase do pioneirismo da produção da rubiácea em território paulista, difundindo-se até 1836 para o vale médio e até 1854 para o vale superior, considerando-se o período de produção máxima aquele entre 1836 e 1886 quando a abolição da escravatura e o cansaço das terras levam ao início da fase de decadência da produção; e, considerando, ainda, que a expansão da cultura do café não se fez de forma ou com intensidade homogênea na região, não é difícil observar que sua influência se fará sentir de forma muito desigual na vida urbana da região até 1836 .

A introdução do café atraiu uma densa ocupação da região, graças à vinda de levas da população das Gerais (motivadas pela decadência da mineração), do litoral (desde São Sebastião até Angra dos Reis), da área fluminense do Paraíba (onde o café alcançava menor produtividade), das áreas ao sopé da Mantiqueira, especialmente Mogi Mirim e Mogi Guaçu (onde o ciclo do açúcar não encontrara, ainda, pleno desenvolvimento), além dos lusitanos que para aí afluíam em proporções quase equivalentes às dos mineiros; e tal intensificação do povoamento levou ao aparecimento de novos aglomerados, seja através do estabelecimento de patrimônio (como foi o caso de São José do Barreiro - fundada em 1803 -, Santa Isabel - surgida nos primeiros anos do período e elevada a vila em 1832 -, e Santa Branca - cujo patrimônio foi instituído em 1833), seja espontaneamente, por concentração em torno de algum elemento de polarização (caso do povoado de Pinheiros - que, na rota dos tropeiros, teve elemento de atração do povoamento na capela construída em 1828 e curada em 1834 -, e de Silveiras - bairro rural que atingiria a posição de freguesia em 1830) (MÜLLER, 1969, p. 30-321). 
De origem diversa dos demais núcleos que surgiram neste período é Queluz, que se prende ao papel de Lorena como centro de povoamento de toda a área que, na fronteira do Estado do Rio de Janeiro, permanecia ainda pouco ocupada. Queluz surge em função dos índios Puri, antigos habitantes da região, que passaram a fazer parte do aldeamento de São João de Queluz, elevado à posição de freguesia em 1803.

Enquanto novos núcleos iam surgindo, alguns dos pré-existentes iam galgando posição na hierarquia administrativa. Paraibuna é elevada a freguesia (1812), enquanto se criam mais quatro vilas - Santa Isabel (1832), Areias (1816), Bananal (1832, freguesia em 1811) e Paraibuna (freguesia em 1812, vila em 1832).

No período áureo da cafeicultura (1832-1886), quando já se tinha ela expandido por todo o vale médio e começava, a passos seguros, a invadir o vale superior, tem-se uma fase de intensificação do processo de urbanização. [...] O vale do Paraíba enriquecer-se-á com onze povoados, alguns, instalando-se através da criação de patrimônios, a maioria surgindo espontaneamente, como povoados ou em conseqüência do desenvolvimento de bairros rurais.

De patrimônio originaram-se Igaratá, Lagoinha, Jambeiro e Guararema.

$[\ldots]$

Como núcleos espontâneos de povoamento, surgem, dentro da fase áurea da cafeicultura, Piquete, Bairro Alto, Monteiro Lobato, Natividade da Serra, Redenção da Serra, Campos de Cunha e Cruzeiro (MÜLLER, 1969, p. 32-33).

Até o final da fase áurea da cafeicultura regional, portanto, assiste-se a um grande conjunto de mudanças das estruturas urbanas (ascensão de povoados a freguesias e de freguesias a vilas, e mudanças de categoria para cidades), que revela a grande vitalidade que a urbanização da região apresenta: conta-se então um total de 15 cidades, 10 vilas, 5 freguesias e 2 povoados. Todavia, tal panorama 
começa a ser abalado pela crise do café que se aproxima, acentuada pela eminente abolição da escravatura. A autora conta que

Pelo ano de 1886, alguns municípios do Vale do Paraíba acusavam decidida decadência da produção de café, pois que ela já se vinha processando há algum tempo; é o caso de Bananal, Jacareí, Santa Isabel, Pindamonhangaba, São Luiz do Paraitinga. Em outros, como Areias, Guaratinguetá, Lorena, São José dos Campos e Taubaté, começava a derrocada, que seria agravada pela abolição da escravatura. [...] Vinda a abolição que todos tiveram que se curvar, [...] agrava-se a situação econômica do Vale do Paraíba (MÜLLER, 1969, p. 35-36).

Portanto, diante das condições de desequilíbrio econômico das últimas décadas do século XIX, não é difícil entender a diminuição do ritmo de urbanização da região e aprova disso é o fato de, neste período, surgir apenas um povoado, São Francisco Xavier, antigo bairro rural do município de São José dos Campos (que torna-se freguesia em 1892). Somando-se duas novas vilas (Aparecida e Piquete, ambas de 1891) e três novas cidades (Santa Isabel, Tremembé e Guararema, de 1893, 1896 e 1898 respectivamente), tem-se o resultado da dinâmica urbanização do Vale do Paraíba no século XIX, totalizando 18 cidades, 12 vilas e três freguesias. Müller conta (1969, p. 37) que

Com a decadência e posterior abandono da cafeicultura na região, fase que, por 1920, estaria praticamente encerrada, o Vale do Paraíba, mais uma vez, tal como acontecera no final do século XVIII, se vê na contingência de procurar novas formas de produção. Nas áreas rurais, generalizam-se as pastagens como forma substitutiva de ocupação do solo, passando a economia a girar em torno da criação de gado, especialmente leiteiro. A substituição de uma forma de agricultura comercial de exportação, exigindo mão-de-obra relativamente abundante, para uma atividade de menor valor comercial envolvendo pessoal reduzido, provocou, a um tempo, o empobrecimento e o despovoamento dos campos. Por isso mesmo, não houve necessidade de criação de novos centros urbanos, interrompendo-se o processo que até então se mantivera em ritmo crescente, pois os existentes mais do que bastavam para atender às necessidades das áreas vizinhas. No século XX, apenas um novo centro urbano surge, Roseira, em 1910. Na 
seqüência evolutiva dos centros urbanos regionais, o fato mais marcante do período é a elevação de onze deles à categoria de cidade [...]. No entanto, o fato não tem o mesmo significado das fases anteriores: enquanto as sedes de município podiam ser sediadas tanto em vilas quanto em cidades, o fato de um núcleo urbano estar em uma ou em outra categoria correspondia, pelo menos relativamente, a certa hierarquia de valores. A partir de 1893, no entanto, todas as sedes de município adquiriram 0 status de "cidade" perdendo o critério administrativo significado como elemento de avaliação do desenvolvimento dos centros urbanos. De qualquer forma, completou-se, então, o conjunto dos centros urbanos da região, de cuja evolução resultou a malha administrativa vigente [...].

O quadro apresentado como apêndice, nesta tese, sintetiza a evolução dos núcleos urbanos do Vale do Paraíba descrita anteriormente acima. Convém dizer que o referido quadro não menciona a existência dos núcleos que deram origem aos municípios de Arujá (que conquistou autonomia político-administrativa em 1959) e Arapeí, Canas e Potim (surgidos na década de 90), possivelmente pela pouca expressividade de seus núcleos originais.

Embora até pouco mais da metade do século $X X$ não tenham surgido novos núcleos no Vale do Paraíba, é a partir deste momento que se dá a definição e a afirmação dos quadros urbanos da região, tomando, as cidades, suas características atuais, e o primeiro fato a chamar a atenção de Müller (1964, p. 6768) na urbanização moderna do Vale do Paraíba é o acelerado ritmo com que ela se efetuou: apenas a título de ilustração, a autora observa que, entre 1934 e 1964, ocorreu uma variação positiva no aumento da população urbana da região de $217,3 \%$ - crescimento que, todavia, quando analisado individualmente em relação aos vários centros, não se apresenta uniforme, quer quanto ao volume absoluto ou proporcional, quer quanto ao ritmo com que se desenvolveu. 
Verificando que a região se vem urbanizando de forma bastante marcante nas primeiras décadas do século $X X$, que essa urbanização não atingiu igualmente, em ritmo e intensidade, os diversos centros regionais, torna-se necessário procurar descobrir as condicionantes gerais e particulares do processo.

É fato bastante conhecido o fenômeno de industrialização da região, sendo ele tacitamente considerado, por comum acordo, como sendo o grande responsável pela urbanização moderna do Vale do Paraíba (MÜLLER, 1969, p. 79).

Diante da decadência do café, assiste-se, ainda em fins do século XIX, ao surgimento das primeiras indústrias na região, entre 1880 e 1890 - resultado, também, do fim das medidas restritivas impostas durante o período colonial (MÜLLER, 1969, p. 80), da oferta de capitais disponíveis com a decadência da cafeicultura, da disponibilidade de mão-de-obra barata em áreas urbanas em função da abolição da escravatura e da menor necessidade de pessoal para a criação de gado e da elevação do nível de vida proporcionada pela euforia econômica criada pelo café, que deveria ser satisfeita pela produção industrial.

Além disso, a situação geográfica da região (localizada entre as cidades de São Paulo e Rio de Janeiro) e as facilidades de comunicação e transportes somaramse às condições favoráveis à industrialização do Vale do Paraíba (p. 81).

Com base na data de fundação das indústrias hoje existentes, pode-se, embora de forma incompleta, ter uma idéia de como se processou a evolução da industrialização da região. [...] A primeira [fase], que vai de 1891 a 1914, se caracteriza pela lenta progressão; [...] na segunda etapa, 1914-1943, praticamente de entre-guerras, há além de incremento da indústria têxtil, maior diversificação da população de estabelecimentos de transformação de minerais não-metálicos, de beneficiamento de produtos agropecuários (especialmente laticínios) e de indústrias da madeira; finalmente, na última fase, aparece a indústria moderna, metalúrgica e mecânica, criando, ao lado da obtenção de bens de consumo, a de bens de produção (MÜLLER, 1969, p. 81-83). 
A autora se detém, ainda, na explicação detalhada do processo de industrialização da região e sua correlação com a urbanização, do crescimento populacional (incluindo as migrações regionais e a imigração) e da evolução urbana, e finaliza a parte inicial de sua obra com a seguinte constatação:

Os núcleos do Vale do Paraíba, apesar de toda sua evolução e "modernização", parecer, de forma geral, subequipados em serviços urbanos. O curioso é que tal fato parece estar, paradoxalmente, preso a um tempo de lentidão e à rapidez do desenvolvimento dos centros urbanos. [...] Chegamos, assim, ao problema básico da vida urbana do Vale do Paraíba, em que os contrastes não chocam apenas pela diferença de tamanho dos centros, mas também pelas condições de vida de suas populações, podendo-se passar de quadros ainda coloniais para a atmosfera de modernas cidades industrializadas, cheias de vida e de dinamismo, representadas pela complexidade ou importância de suas funções (MÜLLER, 1969, p. 115).

Vale mencionar que, embora a autora esteja se referindo a uma situação observada em fins da década de 60 , não é difícil observar ainda hoje tais contrastes entre os municípios da região.

Müller (1969, p. 286-292) apresenta, ainda, uma tentativa de classificação das cidades a partir dos tipos de paisagens urbanas e usa, como critério, "o tamanho dos núcleos, não só em termos de efetivo demográfico como na sua resultante, o espaço urbano", assim compreendidos:

- cidades grandes: Taubaté e São José dos Campos;

- cidades médias: Guaratinguetá ${ }^{56}$, Cruzeiro, Lorena, Jacarei, Caçapava, Aparecida, Pindamonhangaba, Piquete e Cachoeira Paulista;

${ }^{56}$ Grifo nosso. 
- pequenas cidades: Bananal, Guararema, Queluz, Santa Isabel, Cunha ${ }^{57}$, Paraibuna, Santa Branca, São Luís do Paraitinga, Areias, Roseira, São José do Barreiro, Silveiras, Igaratá, Lavrinhas, Monteiro Lobato, Jambeiro, Lagoinha, Natividade da Serra e Redenção da Serra, além das vilas apresentadas no quadro do apêndice desta tese.

Por fim, a autora retoma, na conclusão de seu trabalho, alguns problemas específicos relativos à região como um todo, como o "grande desequilíbrio da vida urbana nas porções correspondentes ao vale médio superior e ao alto vale do Paraíba" (MÜLLER, 1969, p. 348), que resulta na dificuldade de um desenvolvimento harmonioso e integrado da região.

O flagrante contraste entre os pequenos centros localizados fora do vale médio e os que nele se implantaram resulta numa divisão de esforços pouco eqüitativa. Os primeiros, com equipamento mínimo, freqüentemente pouco satisfatório, são levados a gravitar, intensamente, ao redor dos centros maiores, que, nem sempre bem equipados, são obrigados a arcar com sobrecarga que onera suas próprias possibilidades de atendimento e desenvolvimento. Por outro lado, os centros do vale médio, na euforia da industrialização que representa o motor do desenvolvimento urbano, crescem descontroladamente, sem planejamento, sem que os serviços públicos acompanhem sua expansão em ritmo comparável, competindo por ascensões hierárquicas, por vezes acerbamente (MÜLLER, 1969, p. 350).

Müller (1969, p. 350-351) acredita que a situação acima sugere uma série de problemas, entre os quais aponta:

- o problema dos pequenos centros, heranças de um passado que dificultam o desenvolvimento nas condições atuais que, por sua vez, dependeria de um

${ }^{57}$ Grifo nosso. 
amplo plano de ação, possibilitando seu reerguimento de forma que passassem a contar com "um mínimo de serviços para atendimento satisfatório, nos setores básicos, de sua própria população e da área de que são centro";

- o problema dos centros maiores que, embora melhor estruturados, necessitam de uma visão de planejamento de conjunto que levasse em conta os interesses da região, favorecendo complementações ao invés de exacerbar rivalidades;

- esse remanejamento de conjunto deve ser feito levando-se em consideração os componentes não-urbanos da população regional, uma vez que a área rural também poderá renovar-se desde que sejam oferecidas as condições necessárias - na visão da autora, é essencial para a região que se dedique à resolução dos problemas dos pequenos centros, "servindo a áreas rurais, cada vez mais se despovoando e empobrecendo, a fim de, através delas, favorecer o reerguimento de toda a região".

É, pois, nesse cenário que também se insere atividade turística como mais uma alternativa de desenvolvimento regional, cujas condições serão analisadas a seguir, na caracterização dos municípios escolhidos para análise.

\subsubsection{O Município de Guaratinguetá/SP}

Guaratinguetá, distante $168 \mathrm{~km}$ da capital do Estado (GUIA QUATRO RODAS, 2000, p. 173), localiza-se sobre os terraços rochosos dos sítios próximos do rio Paraíba, no Médio Paraíba Superior, conforme classificação das unidades fisiográficas proposta por Müller (1969, p. 232-251). Segundo a autora, 
Trabalhados pelo Paraíba em terrenos cristalinos, terraços desse tipo serviram de sítio a Guaratinguetá e Aparecida. O terraço onde nasceu Guaratinguetá, relativamente estreito, obrigou a cidade a procurar a planície e a extravasar para a outra margem, onde inicialmente ocupou baixo terraço sedimentar e, mais recentemente, começa a invadir colinas terciárias; à margem direita, onde teve origem, a cidade também englobou em seu espaço urbano áreas de colinas cristalinas, de relevo abrupto, como no Bairro das Almas, do outro lado da Via Dutra (MÜLLER, 1969, p. 237-238).

Pelo que aponta a bibliografia especializada, as origens de Guaratinguetá estão ligadas à força de Taubaté como centro irradiador de povoamento, como já mencionado anteriormente.

De fato, cabe lembrar que seu futuro fundador, capitão Domingos Dias Leme, fez parte do grupo de sertanistas comandado pelo líder taubateano [Jaques Félix, responsável pelo surgimento do primeiro núcelo urbano do Vale do Paraíba, a vila de São Franscisco das Chagas de Taubaté] e que, no mesmo ano da expedição de Jaques Félix, 1646, obtivera ele sesmaria nas paragens de Guaratinguetá (HOLANDA, 1964). Apesar da tradição afirmar já existir no local um pequeno povoado desde $1630^{58}$, parece não poder ser ela abonada, já que, então, "toda aquela área se achava ainda inculta e desprovida em geral de meios de comunicação" (HOLANDA, 1964). O que há de certo é que o capitão Domingos Dias Leme, por ordem datada de 13-2-1651, do capitão-mor ouvidor Dionísio da Costa, em nome do Donatário D. Diogo de Faro e Souza, aí levantou pelourinho, sendo a freguesia elevada a vila, com o nome de Santo Antonio de Guaratinguetá ${ }^{59}$ (ZALUAR, 1953 apud MÜLLER, 1969, p. 15).

As condições do sítio onde surgiu o município, descritas anteriormente, acabam por marcar o traçado de Guaratinguetá, "onde o traçado radial, que marca a colina que Ihe serviu de sítio original, contrasta com a simetria do traçado nos terrenos planos da margem esquerda do rio Paraíba" (MÜLLER, 1969, p. 253).

${ }^{58}$ De acordo com o Livro de Tombo da Matriz de Guaratinguetá, parte II, Livro I, p.91 (conforme texto original).

${ }^{59} \mathrm{O}$ nome vem do tupi, Guara-tinga-etá, significando muitos pássaros brancos, muitas garças (MÜLLER, 1969, p.15). 
No século XVIII, Guaratinguetá passa por um crescimento de tipo periférico, "marginando o núcleo inicial, dando começo ao bairro dos Motas, a oeste; e o de Santa Luzia ou Santa Rita, a leste; a única expansão que se projetava para fora do espaço urbano era em direção à saída para Cunha, mas em escala reduzida" (MÜLLER, 1969, p. 45-46).

Ao tentar estabelecer uma hierarquia regional dos núcleos urbanos do século XIX, Müller (1969, p. 50-51), apoiada na literatura consultada, aponta que Guaratinguetá ficaria em segundo lugar em termos de atividades e equipamentos urbanos existentes, cabendo o primeiro lugar a Taubaté.

Guaratinguetá, que a Saint Hilaire pareceu apenas uma "vilazinha", com casas pequenas, sem serem caidadas e só ao rés-do-chão (SAINT HILAIRE, 1938), impressionou, no entanto, a Spix e Martius, quer pela "manifestação de vida mais civilizada", quer pelas vidraças nas janelas, "que sempre significam abastança e mesmo luxo" (SPIX e MARTIUS, 1938). No entanto, tinha "vendas bem sortidas", indicando "que faz algum comércio" (SAINT HILAIRE, 1938). Sua posição como nó de comunicação devia ser importante: a existência de uma rua - a do Porto -, "marginada pelas mais miseráveis choupanas" habitadas por "mulheres de má vida" (SAINT HILAIRE, 1938), atesta que, diante do tamanho do núcleo e dentro da rígida estrutura social vigente, deveria haver uma população flutuante masculina bastante significativa (MÜLLER, 1969, p. 51).

Assim como verificado em boa parte do Vale do Paraíba, Guaratinguetá também assiste, no século $X X$, ao aumento da urbanização e da industrialização. Sua expansão urbana se deu pela comercialização de chácaras localizadas na área central "que haviam logrado resistir, por algum tempo, à tentação de valorização do terreno" (MÜLLER, 1969, p. 106). 
Do ponto-de-vista da industrialização, Guaratinguetá é classificado por Müller (1969, p. 133) como médio centro mono-industrial - classificação resultante da combinação de dois critérios: volume do operariado e tipo de produção industrial.

O município representava, à época da pesquisa de Müller, o terceiro parque têxtil do Vale do Paraíba, seguindo-se a São José dos Campos e Taubaté, "posição essa que, pela menor importância de seus outros estabelecimentos fabris, Ihe deu caráter de centro mono-industrial" (MÜLLER, 1969, p. 148).

O segundo grupo em volume de operariado em Guaratinguetá era representado pelas indústrias químicas que, todavia, ocupavam posição modesta no conjunto da região.

Com pequeno volume de operariado, mas com significado local, há ainda, dois grupos de indústrias, bastante diferentes entre si, mas que têm como denominador comum a posição de Guaratinguetá. O primeiro é constituído pelas indústrias de laticínios, ligada ao fato de ser esse um dos municípios que se inscrevem entre os maiores produtores do Estado $[\ldots]$.

Quanto ao segundo grupo de indústrias ligadas à situação de Guaratinguetá, trata-se de estabelecimentos que, pela proximidade de Aparecida, desenvolveram a produção de imagens religiosas de gesso (MÜLLER, 1969, p. 149).

Ao analisar as diferenciações paisagísticas dos núcleos urbanos do Vale do Paraíba a partir dos elementos que a evolução histórica ou as funções urbanas acrescentaram à fisionomia das cidades, Müller (1969, p. 269) observa que uma das marcas do passado deixadas nas cidades é o traçado irregular das ruas ou a pouca largura que apresentam, conflitantes com a moderna circulação motorizada - o que pode ser observado em Guaratinguetá. 
Além disso, pode-se observar, ainda, no, município, alguns exemplares da arquitetura da época do café, sendo o fator histórico um importante fator de diferenciação entre as cidades de tamanho médio (p. 290).

Considerada uma cidade de tamanho médio conforme classificação apresentada anteriormente, Guaratinguetá, assim como as demais cidades de mesma categoria, tem se expandido em ritmo mais moderado que as cidades consideradas grandes.

Como algumas outras cidades próximas, tem sítio original exíguo, resultando em problemas para sua expansão, tendo que extravasar para a planície do Paraíba, correndo, periodicamente, o risco de inundações; e para colinas próximas. Müller aponta (1969, p. 289) que estas cidades

São cidades de estruturas complexas, em função da própria multiplicação de elementos que compõem seus sítios atuais [...]. Outro ponto comum entre essas cidades é o que deriva da organização de seus aspectos urbanos: possuem todas um "core" de proporções modestas, constituído por pequeno núcleo [...], ou por algumas poucas ruas paralelas, com alguma insinuação pelas transversais .

Por fim, a autora observa que Guaratinguetá diferencia-se destas cidades por contar com um "core" com algum dinamismo, apresentando os primeiros sintomas de crescimento vertical. 


\subsubsection{O Município de Cunha/SP}

Localizado a 218 km do município de São Paulo (GUIA QUATRO RODAS, 2000, p. 127), Cunha localiza-se em um esporão dos terrenos elevados do Alto Paraíba:

Nas cabeceiras do córrego das Pedras, na bacia do Alto Paraitinga, ocupando nível intermediário entre o das planícies e o da Serra de Parari, Cunha se implantou em um dos vários esporões perpendiculares à linha principal de relevo que aí existem. [...] Cunha ocupa o esporão mais amplo e de vertentes mais suaves do conjunto, que, da planície até seu encontro com a serra, apresenta desnível de pouco mais de $100 \mathrm{~m}$. Esse esporão forma ombros mais alargados, um modesto, onde fica a praça da Igreja de São Benedito, outro mais amplo, correspondendo à praça da Matriz. A cidade se alinha pelo seu topo, com casas chegando à beira da vertente oriental, tendo seus habitantes que usar escadas para chegar a seus quintais; a vertente ocidental é ocupada por duas ruas paralelas à principal, em níveis diferentes, e várias transversais, todas elas ladeiras íngremes (MÜLLER, 1969, p. 249-251).

A origem de Cunha está ligada ao surgimento das vias transversais de circulação que iriam proporcionar o início da urbanização fora do caminho geral do vale médio do Paraíba, possibilitando a ligação do interior com o litoral.

Das três últimas [cidades surgidas no caminho para o litoral: Cunha, São Luís do Paraitinga e Paraibuna], Cunha tem posição especial, pois, além de ter precedido de bastante as demais, ficava sobre a rota mais importante, a de Guaratinguetá para Parati, por onde se fazia a ligação com o Rio de Janeiro, por via marítima. Ao longo desse caminho, havia três pequenos povoados: Campo Alegre, Facão e Boa Vista, mas, quando as autoridades eclesiásticas resolveram crirar paróquia na zona, Facão, que datava de 1723, foi o preferido. Assim se fazendo, reconhecia-se sua situação favorável, a meio caminho entre as duas cidades, Guaratinguetá e Parati, a cavaleiro da escarpa da Serra do Mar. Entre 1736 e $1749^{60}$, foi criada a freguesia de N. Sra. da Conceição do Facão, que, em 1785, passaria a vila, como N. Sra. da Conceição de Cunha. ${ }^{61}$

${ }^{60}$ A data é imprecisa, conforme assinala SILVEIRA (1939 apud MÜLLER, 1969, p.22).

${ }^{61}$ A origem do nome Facão deu margem a controvérsias. Alguns, como RIBEIRO (1899-1901) e FORJAZ (1931), aceitam a versão de o nome ter derivado de uma família Falcon, que aí se teria instalado por volta de 1730; outros, como SILVEIRA (1939), crêem que o nome viria do sítio do 
Cunha, a exemplo de outros aglomerados, apresentou ao mesmo tempo, uma vida urbana relativamente restrita e algum desenvolvimento no século XVIII, quase sempre crescendo em direção às vias de saída, chegando, em conseqüência, a tomar aspecto nitidamente alongado, acompanhando o eixo da estrada ParatiGuaratinguetá (MÜLLER, 1969, p. 45). E é no período áureo da cafeicultura, no século seguinte, que Cunha torna-se cidade, em 1858 (p. 35).

Quanto à urbanização e à evolução urbana de Cunha no século $X X$, dois fatos merecem destaque: Cunha só terá a estrada para Parati melhorada em 1954-55 e, das três cidades existentes no traçado de vias para o litoral, Cunha foi a que mais cresceu e mais se expandiu (MÜLLER, 1969, p. 108).

Mas isso só mais recentemente, da segunda metade da década de 1950 para cá. Ainda em 1945, dizia-se que "na cidade alta não há mais que uma dúzia de prédios construídos nos últimos dez anos" (WILLENS, 1947), mas, no ano de 1959, registravam-se 180 novas casa no perímetro urbano. As autoridades locais explicam o fenômeno pela fundação do Ginásio, em 1956, que teria atraído para a cidade famílias da área rural que tinham filhos em idade de estudar e que, com essa oportunidade, não mais precisariam enviá-los para Guaratinguetá ou outra cidade da região; no entanto, é curiosa a coincidência com a melhoria da estrada para Parati (1954-55), que veio restabelecer a posição de Cunha como núcleo intermediário entre o litoral e o vale médio na era da circulação motorizada. Apesar de afirmarem os habitantes da cidade que o trânsito de ônibus entre Guaratinguetá e Parati apenas "beneficia alguns bares", acreditamos que a maior facilidade de comunicação fez com que famílias de Parati aí se instalassem [...], e outras, da área rural, já não preferissem a cidade maior, que poderia ser rapidamente atingida, para ficar mais próximas de suas propriedades. Isso, com ou sem influência da presença do Ginásio. Este fato não parece tão relevante, uma vez que São Luís do Paraitinga,

núcleo, em um contraforte ou "facão" da serra. Contra a primeira hipótese, argumenta RODRIGUES (1957) que o nome Facão já aparecia como designativo do povoado entre 1723 e 1725, anteriormente, portanto, à vinda da família Falcon; SILVEIRA (1939) acrescenta que o nome Facão não é encontrado nos primeiros recenseamentos de Cunha (1765-66), onde constam os descendentes de todos os povoadores. Quanto ao nome Cunha, teria sido escolhido em homenagem ao capitão-general Francisco da Cunha Menezes, quem concedeu o povoado a ascensão à vila (MÜLLER, 1969, p.22). 
que também possui estabelecimento de ensino secundário, não teve seu espaço urbano tão aumentado quanto Cunha (MÜLLER, 1969, p. 108).

De acordo com a classificação proposta por Müller (1969, p. 133-153), Cunha é um dos centros urbanos do Vale da Paraíba, que tem função industrial pouco significativa ou apenas incipiente, apresentando um único estabelecimento - a usina de pasteurização de leite - que Ihes dá caráter mono-industrial absoluto, mas, evidentemente, sem que tenham grande significado econômico.

Apresentando-se com decisiva preoeminência na paisagem, a autora classifica Cunha, do ponto-de-vista da paisagem urbana, como uma das muitas pequenas cidades do Vale do Paraíba e comenta que

em alguns centros urbanos [como ocorre em Cunha], por mais modesto e por menos diferenciado que seja, a presença de um 'core' contribui para certa diversificação, estabelecendo algum contraste entre área de serviços e área estritamente residencial (MÜLLER, 1969, p. 291).

Assim, também, como em outras cidades quase estagnadas desde os tempos do café, Cunha guarda vestígios deste período de desenvolvimento do passado e possui aspecto pacato, tendo suas ruas relativamente movimentadas apenas quando estão numa via de circulação de certa importância, nos dias de mercado ou de festa (MÜLLER, 1969, p. 291). A partir desta introdução histórico-geográfica dos municípios de Guaratinguetá e Cunha, apresenta-se, no capítulo seguinte, sua caracterização turística, bem como a análise de tal configuração à luz do instrumento ora proposto. 


\section{OS ESTUDOS DE POTENCIALIDADE TURÍSTICA DE GUARATINGUETÁ E CUNHA/SP - PROPOSTA DE MATRIZ DE AVALIAÇÃO DO POTENCIAL TURÍSTICO DE LOCALIDADES RECEPTORAS E SUA APLICAÇÃO NOS MUNICÍPIOS-OBJETOS DE ESTUDO}

\subsection{Considerações Metodológicas}

Diante da análise de todo o referencial bibliográfico encontrado, é possível constatar que a maior parte dos métodos mencionados no primeiro capítulo desta tese enfoca a análise de atrativos (ou recursos) turísticos como a base do processo de avaliação das destinações - quando não, como a única avaliação a ser feita que, por vezes, incorpora a avaliação daqueles equipamentos e serviços unicamente vinculados a tais atrativos e recursos.

Os métodos de análise de atratividade e hierarquização de destinos turísticos focam-se no potencial de atratividade de destinos turísticos de maneira comparativa, utilizando os atrativos como elementos principais para chegar ao nível de atratividade dos destinos. Em geral, são métodos bastante complexos, pois precisam analisar o destino sob uma ótica específica, com determinantes consistentes e bem elaborados, a fim de alcançar um resultado que dê bases à comparação entre destinos (FAGLIARI e ALMEIDA, 2004, p.32-33).

Todavia, embora obviamente reconheça-se a importância dos atrativos no processo de captação da demanda real e/ou potencial, defende-se aqui a necessidade de relativizar tal importância ao se atribuir importância também a outros fatores pouco ou nada considerados nos métodos anteriormente estudados. 
Outra observação que pode ser feita diz respeito aos tipos de métodos encontrados que, de acordo com a classificação de Smith (1992, p.19-49), concentram-se em métodos e técnicas de investigação descritiva de lugares dos tipos:

- descrição da localização de instalações e atividades;

- inventário de recursos (métodos aritméticos e métodos separativos, preponderantemente).

Tendo em vista a necessidade da elaboração de um instrumento de avaliação que possibilite a sua aplicação sem maiores dificuldades (a fim de promover sua efetiva utilização) $)^{62}$ e, ao mesmo tempo, levando-se em consideração as recomendações de Fagliari e Almeida (citação supra) no que diz respeito às exigências de tal método, propõe-se a criação de uma matriz de avaliação do potencial turístico de localidades receptoras. Em termos de estrutura, esta matriz é composta por quatro níveis hierárquicos inter-relacionados, correspondentes aos seguintes aspectos ${ }^{63}$ :

- dimensão: diz respeito aos grandes temas sob os quais estão agrupados os aspectos que devem ser observados nas localidades turísticas, compreendendo:

- atrativos turísticos: "[...] todo o lugar, objeto ou acontecimento de interesse turístico que motiva o deslocamento de grupos humanos para conhecê-los" (EMPRESA BRASILEIRA DE TURISMO, 1984, p.8);

\footnotetext{
${ }^{62}$ A facilidade que se pretende conferir à matriz ora proposta, ao contrário da Matriz de Avaliação do Projeto Pólos de Desenvolvimento de Ecoturismo no Brasil, não pressupõe a sua aplicação por leigos no assunto, mas, ao contrário, depende da participação de especialistas para a criteriosa inserção dos dados e adequada análise e avaliação dos resultados.
} 
- equipamentos e serviços turísticos: "[...] conjunto de edificações, de instalações e serviços indispensáveis ao desenvolvimento da atividade turística. Compreendem os meios de hospedagem, serviços de alimentação, de entretenimento, de agenciamento, de informação e outros serviços" (EMPRESA BRASILEIRA DE TURISMO, 1984, p.8);

- infra-estrutura de apoio turístico: "[...] conjunto de obras e instalações de estrutura física de base, que criam condições para o desenvolvimento de uma unidade turística, tais como: sistema de transportes, de comunicações, serviços urbanos (água, luz, esgoto, limpeza pública) etc.” (EMPRESA BRASILEIRA DE TURISMO, 1984, p.8);

- normativo-institucional: conjunto de estruturas e organizações oficiais e não governamentais responsáveis pelo planejamento e pela gestão pública e compartilhada do turismo na localidade e dos instrumentos facilitadores destes processos, incluindo a gestão mercadológica da localidade como produto turístico;

- planejamento turístico participativo: corresponde à análise dos níveis de envolvimento e aceitação da comunidade local nos processos de planejamento e/ou desenvolvimento turístico da localidade;

- outros fatores pertinentes aos processos de planejamento e/ou desenvolvimento turístico da localidade, como a proximidade dos núcleos emissores de demanda, a disponibilidade de áreas para possível expansão futura dos atrativos e/ou equipamentos turísticos e a disponibilidade de mãode-obra para atendimento ao turista;

\footnotetext{
${ }^{63}$ Baseados em estrutura semelhante, integrante dos manuais de avaliação do ensino superior do Ministério da Educação (BRASIL, 2002, p.16-18).
} 
- categorias de análise: detalhamento dos aspectos que devem ser observados, organizados, cada um, também em níveis, de acordo com as características mais pertinentes ao processo, conforme apresentado na matriz a seguir;

- indicadores: são os desdobramentos das categorias de análise, conforme apresentado na matriz a seguir;

- critérios de análise: são os parâmetros para avaliação, que possibilitam a respectiva atribuição de pontos.

A cada um dos critérios foram atribuídos pontos em uma escala decrescente de 5 a 1, com exceção do indicador "existência e gestão de fundo municipal de turismo" (categoria de análise "estrutura da dimensão normativo-institucional") e de todos os indicadores da categoria de análise "instrumentos de planejamento e gestão pública e compartilhada do turismo" ${ }^{4}$, de forma que parte-se do aspecto que, se contemplado no atrativo, equipamento, serviço ou na destinação como um todo, indica maior resultado que os indicados na seqüência de cada critério de análise.

Para a definição das dimensões "atrativos turísticos", "equipamentos e serviços turísticos" e "infra-estrutura de apoio turístico", e suas respectivas categorias de análise, utilizou-se como base, com as devidas adaptações, a metodologia de inventário da oferta turística da então Empresa Brasileira de Turismo (1984), por tratar-se de instrumento oficial ${ }^{65}$, desenvolvido a partir dos trabalhos do

\footnotetext{
${ }^{64}$ Acredita-se que tais indicadores possam ser avaliados com base em uma atribuição diferenciada de pontos, conforme demonstrado a seguir na matriz de avaliação, dada a menor possibilidade de variação dos critérios de avaliação destes indicadores em particular.

65 Esta metodologia está sendo revista pelo atual Ministério do Turismo, para posterior disseminação e aplicação no território brasileiro; todavia, optou-se por utilizar a metodologia publicada em 1984, dada sua popularidade e possibilidade de adaptação para a nova metodologia, quando disponível oficialmente, uma vez que esta traduz-se muito mais em um aprimoramento da anterior do que na construção de uma metodologia inteiramente nova, segundo informações
} 
CICATUR/OEA, já mencionados anteriormente. As demais dimensões foram incorporadas pelo autor.

Os critérios para avaliação da dimensão "atrativos turísticos" (hierarquização) seguem a proposta de Leno Cerro (1993, p.48), que acrescenta um nível à hierarquização estabelecida pelo CICATUR/OEA.

Os critérios para avaliação da dimensões "existência de áreas para expansão dos atrativos e/ou equipamentos turísticos" e "existência de mão-de-obra em quantidade e qualidade para atendimento ao turista" (categorias "disponibilidade de áreas para expansão" e "disponibilidade de mão-de-obra", respectivamente foram elaborados com base em Cárdenas Tabares (1994, p.34-35). Os critérios para avaliação das demais dimensões foram elaborados pelo autor.

disponíveis sobre o assunto. Além disso, é possível que algumas outras localidades turísticas já possuam informações sobre suas ofertas turísticas organizadas segundo esta metodologia, o que possibilitaria o aproveitamento das informações já existentes. 


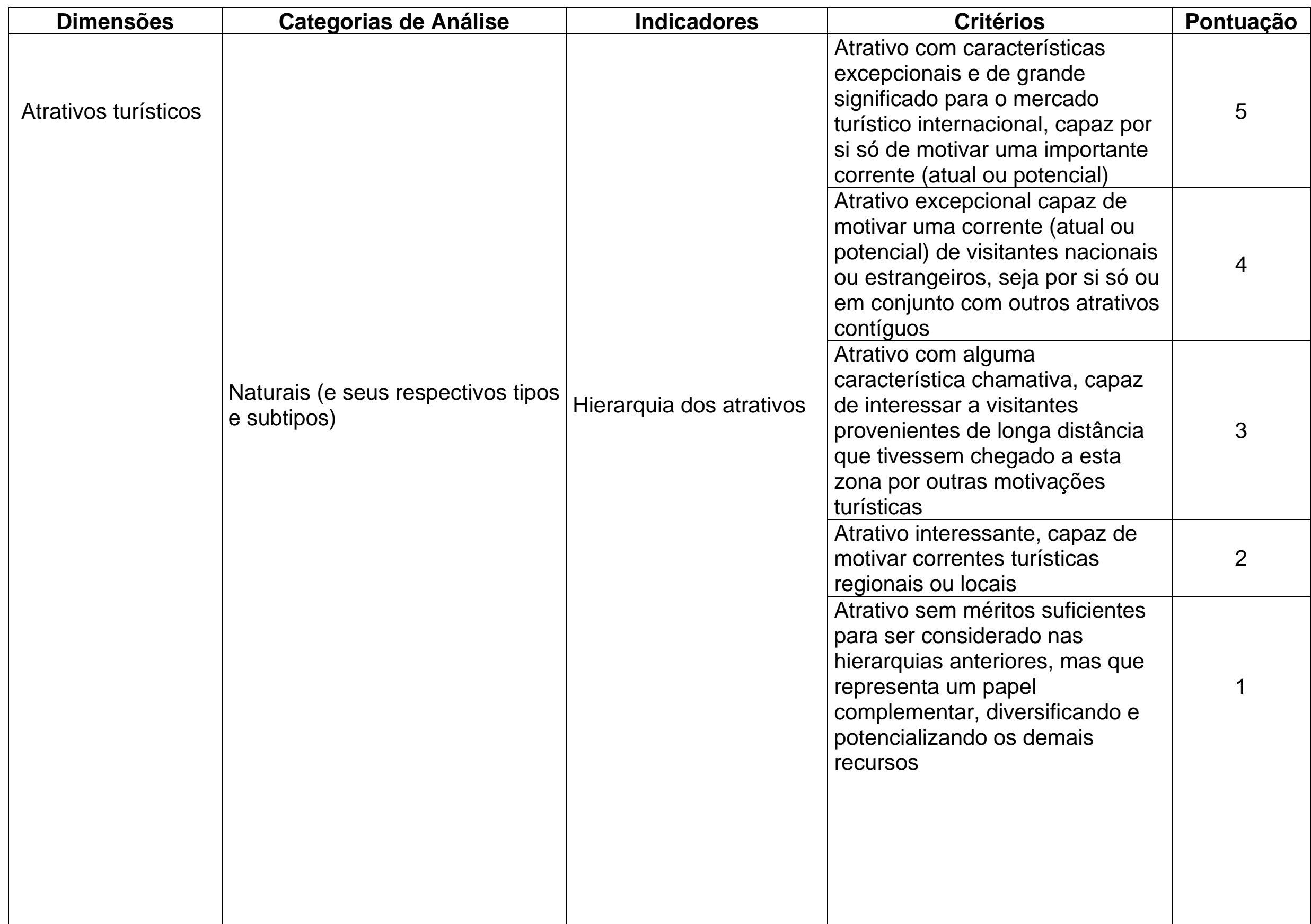




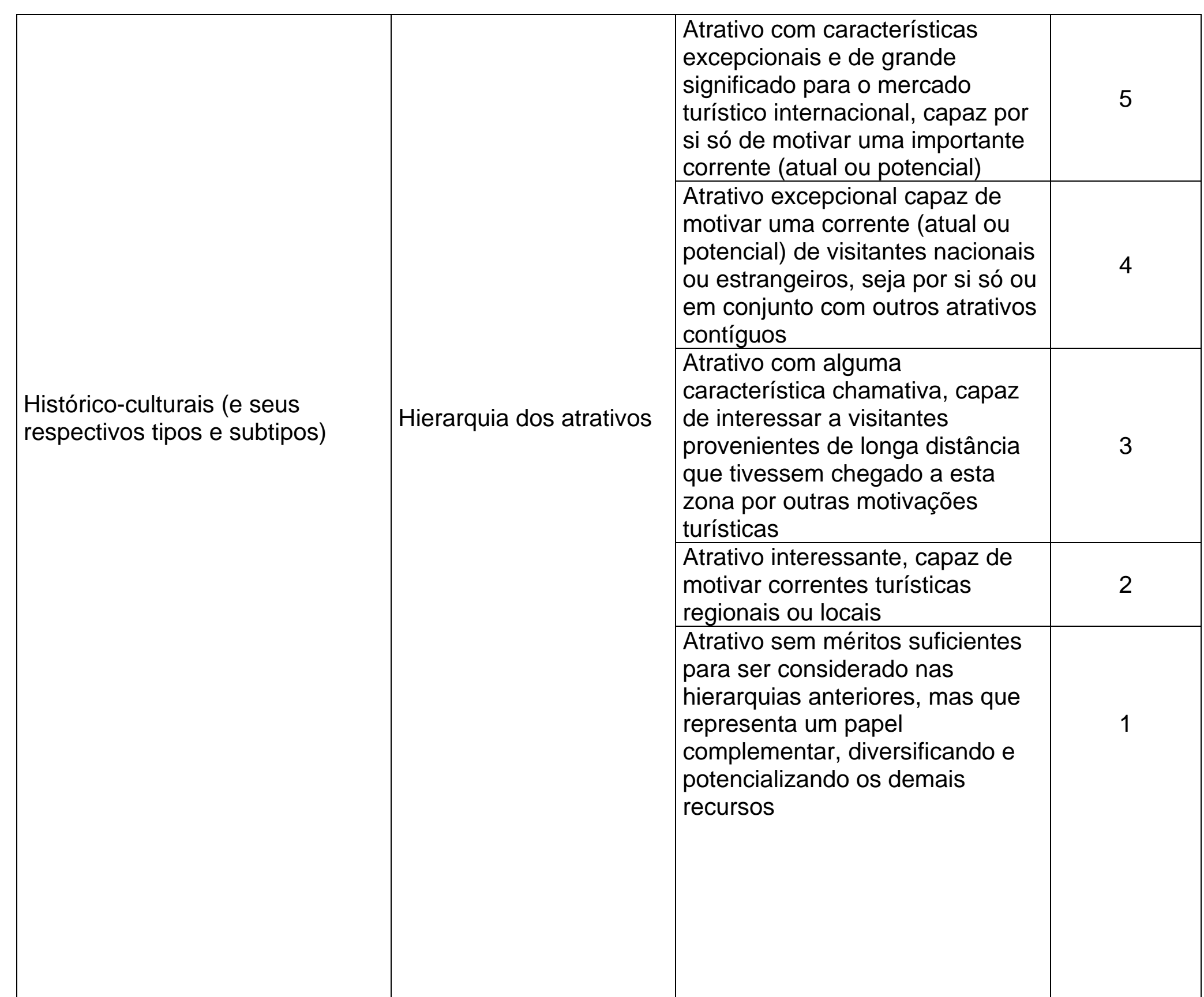




\begin{tabular}{|c|c|c|c|}
\hline \multirow{5}{*}{$\begin{array}{l}\text { Manifestações e usos tradicionais } \\
\text { e populares (e seus respectivos } \\
\text { tipos e subtipos) }\end{array}$} & \multirow{5}{*}{ Hierarquia dos atrativos } & $\begin{array}{l}\text { Atrativo com características } \\
\text { excepcionais e de grande } \\
\text { significado para o mercado } \\
\text { turístico internacional, capaz por } \\
\text { si só de motivar uma importante } \\
\text { corrente (atual ou potencial) }\end{array}$ & 5 \\
\hline & & $\begin{array}{l}\text { Atrativo excepcional capaz de } \\
\text { motivar uma corrente (atual ou } \\
\text { potencial) de visitantes nacionais } \\
\text { ou estrangeiros, seja por si só ou } \\
\text { em conjunto com outros atrativos } \\
\text { contíguos }\end{array}$ & 4 \\
\hline & & $\begin{array}{l}\text { Atrativo com alguma } \\
\text { característica chamativa, capaz } \\
\text { de interessar a visitantes } \\
\text { provenientes de longa distância } \\
\text { que tivessem chegado a esta } \\
\text { zona por outras motivações } \\
\text { turísticas } \\
\end{array}$ & 3 \\
\hline & & $\begin{array}{l}\text { Atrativo interessante, capaz de } \\
\text { motivar correntes turísticas } \\
\text { regionais ou locais }\end{array}$ & 2 \\
\hline & & $\begin{array}{l}\text { Atrativo sem méritos suficientes } \\
\text { para ser considerado nas } \\
\text { hierarquias anteriores, mas que } \\
\text { representa um papel } \\
\text { complementar, diversificando e } \\
\text { potencializando os demais } \\
\text { recursos }\end{array}$ & 1 \\
\hline
\end{tabular}




\begin{tabular}{|c|c|c|c|}
\hline \multirow{5}{*}{$\begin{array}{l}\text { Realizações técnicas e científicas } \\
\text { contemporâneas (e seus } \\
\text { respectivos tipos e subtipos) }\end{array}$} & \multirow{5}{*}{ Hierarquia dos atrativos } & $\begin{array}{l}\text { Atrativo com características } \\
\text { excepcionais e de grande } \\
\text { significado para o mercado } \\
\text { turístico internacional, capaz por } \\
\text { si só de motivar uma importante } \\
\text { corrente (atual ou potencial) }\end{array}$ & 5 \\
\hline & & $\begin{array}{l}\text { Atrativo excepcional capaz de } \\
\text { motivar uma corrente (atual ou } \\
\text { potencial) de visitantes nacionais } \\
\text { ou estrangeiros, seja por si só ou } \\
\text { em conjunto com outros atrativos } \\
\text { contíguos }\end{array}$ & 4 \\
\hline & & $\begin{array}{l}\text { Atrativo com alguma } \\
\text { característica chamativa, capaz } \\
\text { de interessar a visitantes } \\
\text { provenientes de longa distância } \\
\text { que tivessem chegado a esta } \\
\text { zona por outras motivações } \\
\text { turísticas }\end{array}$ & 3 \\
\hline & & $\begin{array}{l}\text { Atrativo interessante, capaz de } \\
\text { motivar correntes turísticas } \\
\text { regionais ou locais }\end{array}$ & 2 \\
\hline & & $\begin{array}{l}\text { Atrativo sem méritos suficientes } \\
\text { para ser considerado nas } \\
\text { hierarquias anteriores, mas que } \\
\text { representa um papel } \\
\text { complementar, diversificando e } \\
\text { potencializando os demais } \\
\text { recursos }\end{array}$ & 1 \\
\hline
\end{tabular}




\begin{tabular}{|c|c|c|c|}
\hline \multirow{5}{*}{$\begin{array}{l}\text { Acontecimentos programados (e } \\
\text { seus respectivos tipos e subtipos) }\end{array}$} & \multirow{5}{*}{ Hierarquia dos atrativos } & $\begin{array}{l}\text { Atrativo com características } \\
\text { excepcionais e de grande } \\
\text { significado para o mercado } \\
\text { turístico internacional, capaz por } \\
\text { si só de motivar uma importante } \\
\text { corrente (atual ou potencial) }\end{array}$ & 5 \\
\hline & & $\begin{array}{l}\text { Atrativo excepcional capaz de } \\
\text { motivar uma corrente (atual ou } \\
\text { potencial) de visitantes nacionais } \\
\text { ou estrangeiros, seja por si só ou } \\
\text { em conjunto com outros atrativos } \\
\text { contíguos }\end{array}$ & 4 \\
\hline & & $\begin{array}{l}\text { Atrativo com alguma } \\
\text { característica chamativa, capaz } \\
\text { de interessar a visitantes } \\
\text { provenientes de longa distância } \\
\text { que tivessem chegado a esta } \\
\text { zona por outras motivações } \\
\text { turísticas }\end{array}$ & 3 \\
\hline & & $\begin{array}{l}\text { Atrativo interessante, capaz de } \\
\text { motivar correntes turísticas } \\
\text { regionais ou locais }\end{array}$ & 2 \\
\hline & & $\begin{array}{l}\text { Atrativo sem méritos suficientes } \\
\text { para ser considerado nas } \\
\text { hierarquias anteriores, mas que } \\
\text { representa um papel } \\
\text { complementar, diversificando e } \\
\text { potencializando os demais } \\
\text { recursos }\end{array}$ & 1 \\
\hline
\end{tabular}


Estrutura dos equipamentos
Meios de hospedagem -

Equipamentos e serviços turísticos

\section{estabelecimentos hoteleiros}

Equipamento com capacidade altamente favorável em número de unidades habitacionais, instalações e serviços para atender satisfatoriamente turistas, individualmente ou em grupos

Equipamento com capacidade favorável em número de unidades habitacionais, instalações e serviços para atender satisfatoriamente turistas, individualmente ou em grupos

Equipamento com capacidade restrita em número de unidades habitacionais, instalações e serviços para atender satisfatoriamente turistas, individualmente ou em grupos Equipamento com capacidade precária em número de unidades habitacionais, instalações e serviços para atender satisfatoriamente turistas, individualmente ou em grupos Equipamento com capacidade precária em número de unidades habitacionais, instalações e serviços sem condições para em grupos 


\begin{tabular}{|c|c|c|c|}
\hline & \multirow{5}{*}{$\begin{array}{l}\text { Qualidade dos } \\
\text { equipamentos e serviços }\end{array}$} & $\begin{array}{l}\text { Equipamento com qualidade } \\
\text { altamente satisfatória para } \\
\text { atender turistas, individualmente } \\
\text { ou em grupos }\end{array}$ & 5 \\
\hline & & $\begin{array}{l}\text { Equipamento com qualidade } \\
\text { satisfatória para atender turistas, } \\
\text { individualmente ou em grupos }\end{array}$ & 4 \\
\hline & & $\begin{array}{l}\text { Equipamento em condições } \\
\text { mínimas para atender turistas, } \\
\text { individualmente ou em grupos }\end{array}$ & 3 \\
\hline & & $\begin{array}{l}\text { Equipamento sem condições } \\
\text { para atender satisfatoriamente } \\
\text { turistas em grupos }\end{array}$ & 2 \\
\hline & & $\begin{array}{l}\text { Equipamento sem condições } \\
\text { para atender satisfatoriamente } \\
\text { turistas individualmente }\end{array}$ & 1 \\
\hline \multirow[t]{2}{*}{$\begin{array}{l}\text { Meios de Hospedagem - } \\
\text { estabelecimentos extra-hoteleiros }\end{array}$} & \multirow[t]{2}{*}{$\begin{array}{l}\text { Estrutura dos } \\
\text { equipamentos }\end{array}$} & $\begin{array}{l}\text { Equipamento com capacidade } \\
\text { altamente favorável em número } \\
\text { de unidades habitacionais, } \\
\text { instalações e serviços para } \\
\text { atender satisfatoriamente } \\
\text { turistas, individualmente ou em } \\
\text { grupos }\end{array}$ & 5 \\
\hline & & $\begin{array}{l}\text { Equipamento com capacidade } \\
\text { favorável em número de } \\
\text { unidades habitacionais, } \\
\text { instalações e serviços para } \\
\text { atender satisfatoriamente } \\
\text { turistas, individualmente ou em } \\
\text { grupos }\end{array}$ & 4 \\
\hline
\end{tabular}




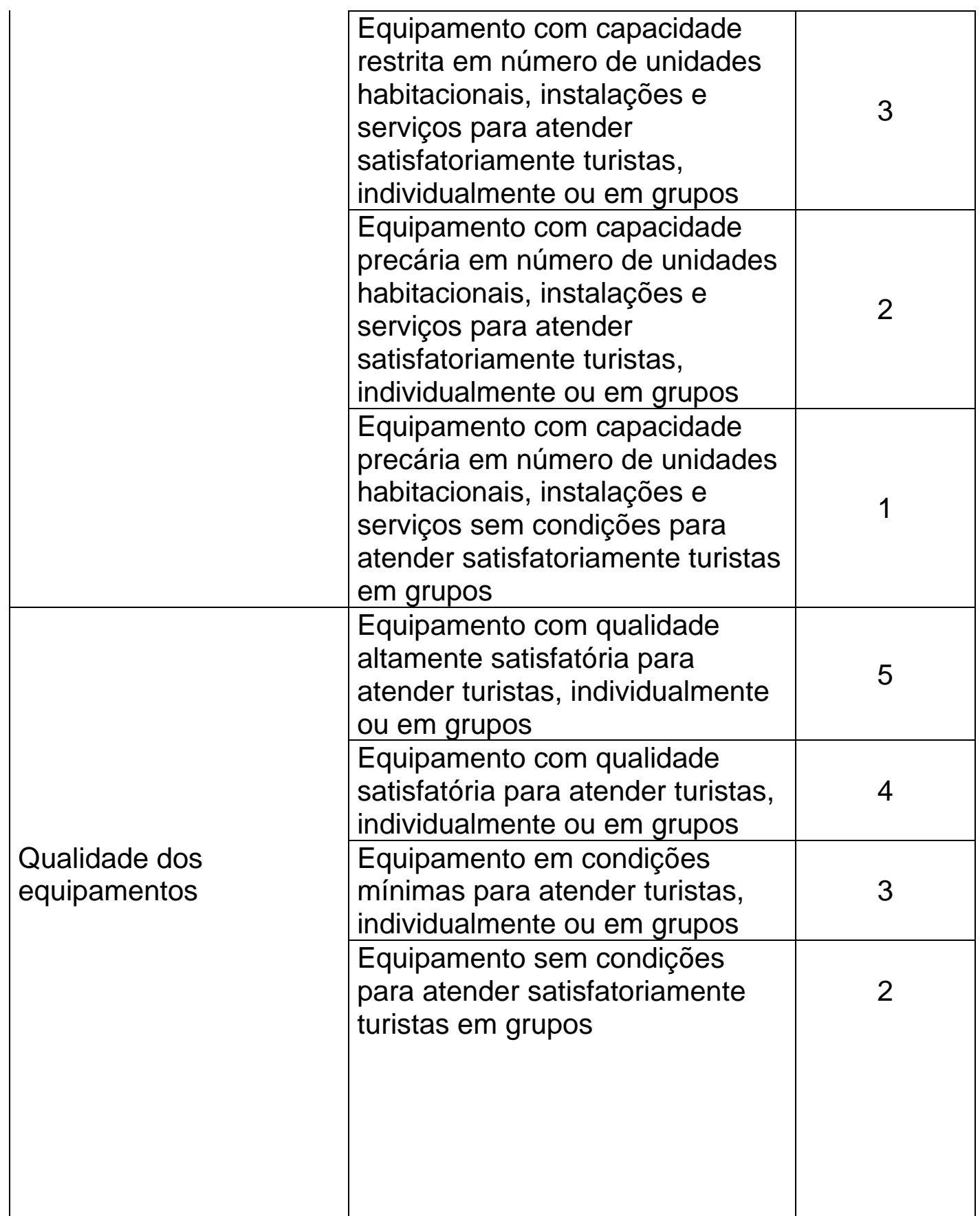




\begin{tabular}{|c|c|c|c|}
\hline & & $\begin{array}{l}\text { Equipamento sem condições } \\
\text { para atender satisfatoriamente } \\
\text { turistas individualmente }\end{array}$ & 1 \\
\hline \multirow[t]{6}{*}{ Alimentação } & \multirow{5}{*}{$\begin{array}{l}\text { Estrutura dos } \\
\text { equipamentos }\end{array}$} & $\begin{array}{l}\text { Equipamento com capacidade } \\
\text { altamente favorável quanto a } \\
\text { instalações e serviços para } \\
\text { atender satisfatoriamente } \\
\text { turistas, individualmente ou em } \\
\text { grupos }\end{array}$ & 5 \\
\hline & & $\begin{array}{l}\text { Equipamento com capacidade } \\
\text { favorável quanto a instalações e } \\
\text { serviços para atender } \\
\text { satisfatoriamente turistas, } \\
\text { individualmente ou em grupos }\end{array}$ & 4 \\
\hline & & $\begin{array}{l}\text { Equipamento com capacidade } \\
\text { restrita quanto a instalações e } \\
\text { serviços para atender } \\
\text { satisfatoriamente turistas, } \\
\text { individualmente ou em grupos }\end{array}$ & 3 \\
\hline & & $\begin{array}{l}\text { Equipamento com capacidade } \\
\text { precária quanto a instalações e } \\
\text { serviços para atender } \\
\text { satisfatoriamente turistas, } \\
\text { individualmente ou em grupos }\end{array}$ & 2 \\
\hline & & $\begin{array}{l}\text { Equipamento sem condições } \\
\text { para atender satisfatoriamente } \\
\text { turistas em grupos quanto a } \\
\text { instalações e serviços }\end{array}$ & 1 \\
\hline & $\begin{array}{l}\text { Qualidade dos } \\
\text { equipamentos, serviços } \\
\text { e produtos }\end{array}$ & $\begin{array}{l}\text { Equipamento com qualidade } \\
\text { altamente satisfatória para } \\
\text { atender turistas, individualmente } \\
\text { ou em grupos }\end{array}$ & 5 \\
\hline
\end{tabular}




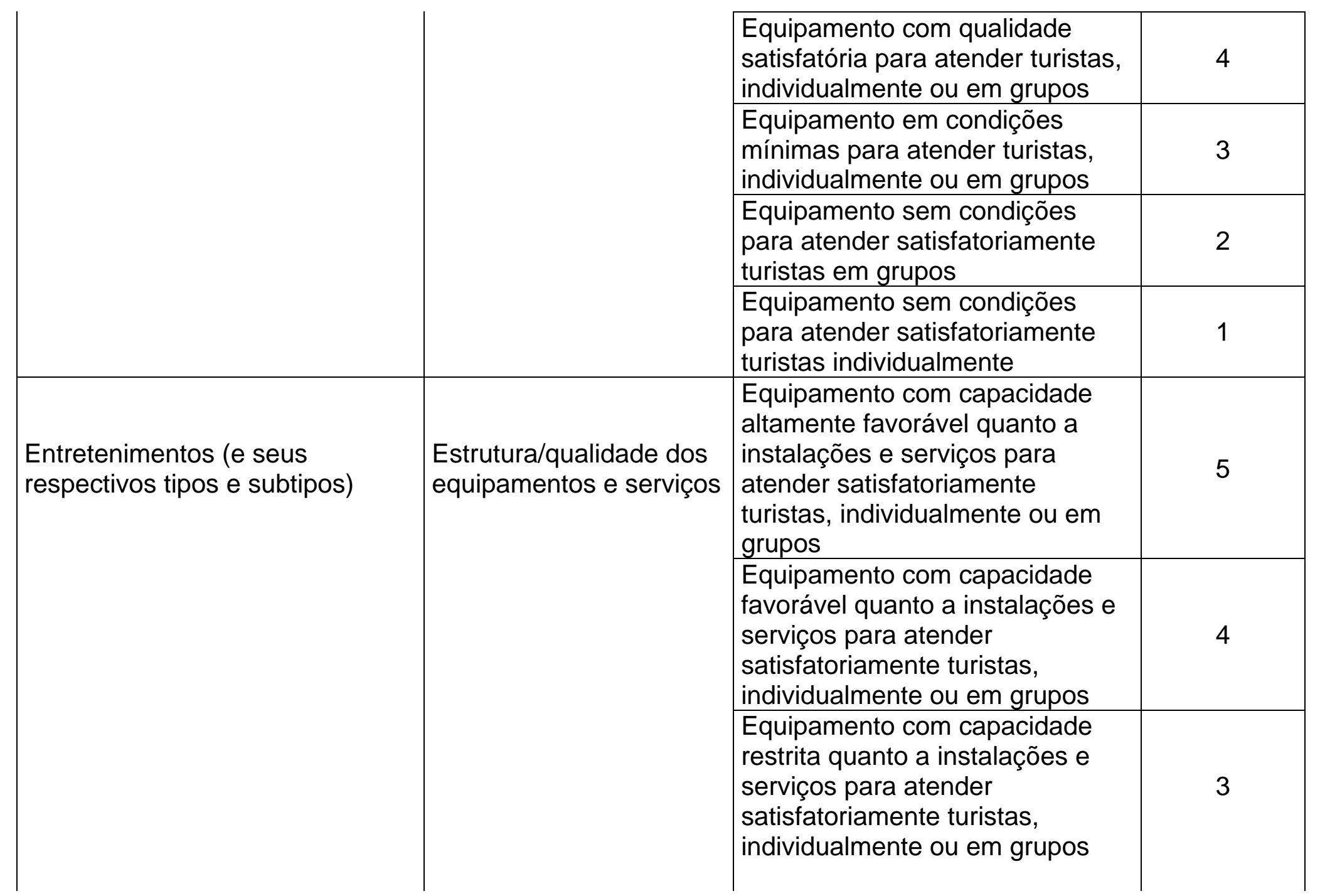




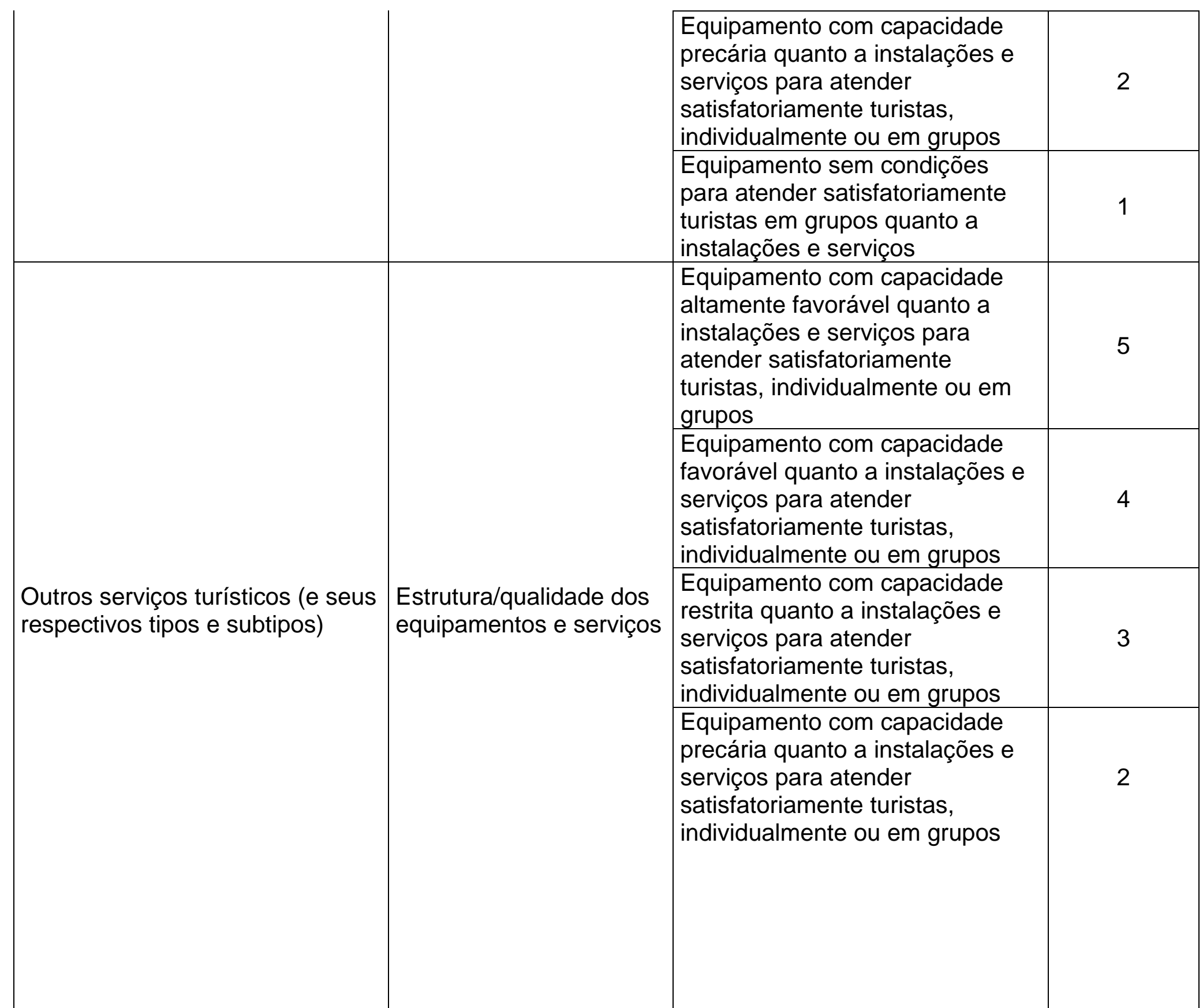




\begin{tabular}{|c|c|c|c|c|}
\hline & & & $\begin{array}{l}\text { Equipamento sem condições } \\
\text { para atender satisfatoriamente } \\
\text { turistas em grupos quanto a } \\
\text { instalações e serviços }\end{array}$ & 1 \\
\hline \multirow[t]{6}{*}{$\begin{array}{l}\text { Infra-estrutura de } \\
\text { apoio turístico }\end{array}$} & \multirow{5}{*}{$\begin{array}{l}\text { Serviços urbanos (abastecimento } \\
\text { de água, rede de esgotos, } \\
\text { limpeza pública, e energia } \\
\text { elétrica) }\end{array}$} & \multirow{5}{*}{$\begin{array}{l}\text { Estrutura e qualidade } \\
\text { dos serviços }\end{array}$} & $\begin{array}{l}\text { Estrutura em condições } \\
\text { altamente favoráveis para } \\
\text { atender satisfatoriamente a } \\
\text { população local e/ou a demanda } \\
\text { turística }\end{array}$ & 5 \\
\hline & & & $\begin{array}{l}\text { Estrutura em condições } \\
\text { favoráveis para atender } \\
\text { satisfatoriamente a população } \\
\text { local e/ou a demanda turística }\end{array}$ & 4 \\
\hline & & & $\begin{array}{l}\text { Estrutura em condições restritas } \\
\text { para atender satisfatoriamente a } \\
\text { população local e/ou a demanda } \\
\text { turística }\end{array}$ & 3 \\
\hline & & & $\begin{array}{l}\text { Estrutura em condições precárias } \\
\text { para atender satisfatoriamente a } \\
\text { população local e/ou a demanda } \\
\text { turística }\end{array}$ & 2 \\
\hline & & & $\begin{array}{l}\text { Estrutura sem condições para } \\
\text { atender satisfatoriamente a } \\
\text { população local e/ou a demanda } \\
\text { turística }\end{array}$ & 1 \\
\hline & Acesso rodoviário à localidade & $\begin{array}{l}\text { Condições das vias de } \\
\text { acesso e dos recursos, } \\
\text { serviços e instalações de } \\
\text { apoio a veículos } \\
\text { (sinalização rodoviária e } \\
\text { turística, postos de } \\
\text { abastecimento e } \\
\text { serviços etc.) }\end{array}$ & $\begin{array}{l}\text { Estrutura em condições } \\
\text { altamente favoráveis para } \\
\text { atender satisfatoriamente a } \\
\text { população local e/ou a demanda } \\
\text { turística }\end{array}$ & 5 \\
\hline
\end{tabular}




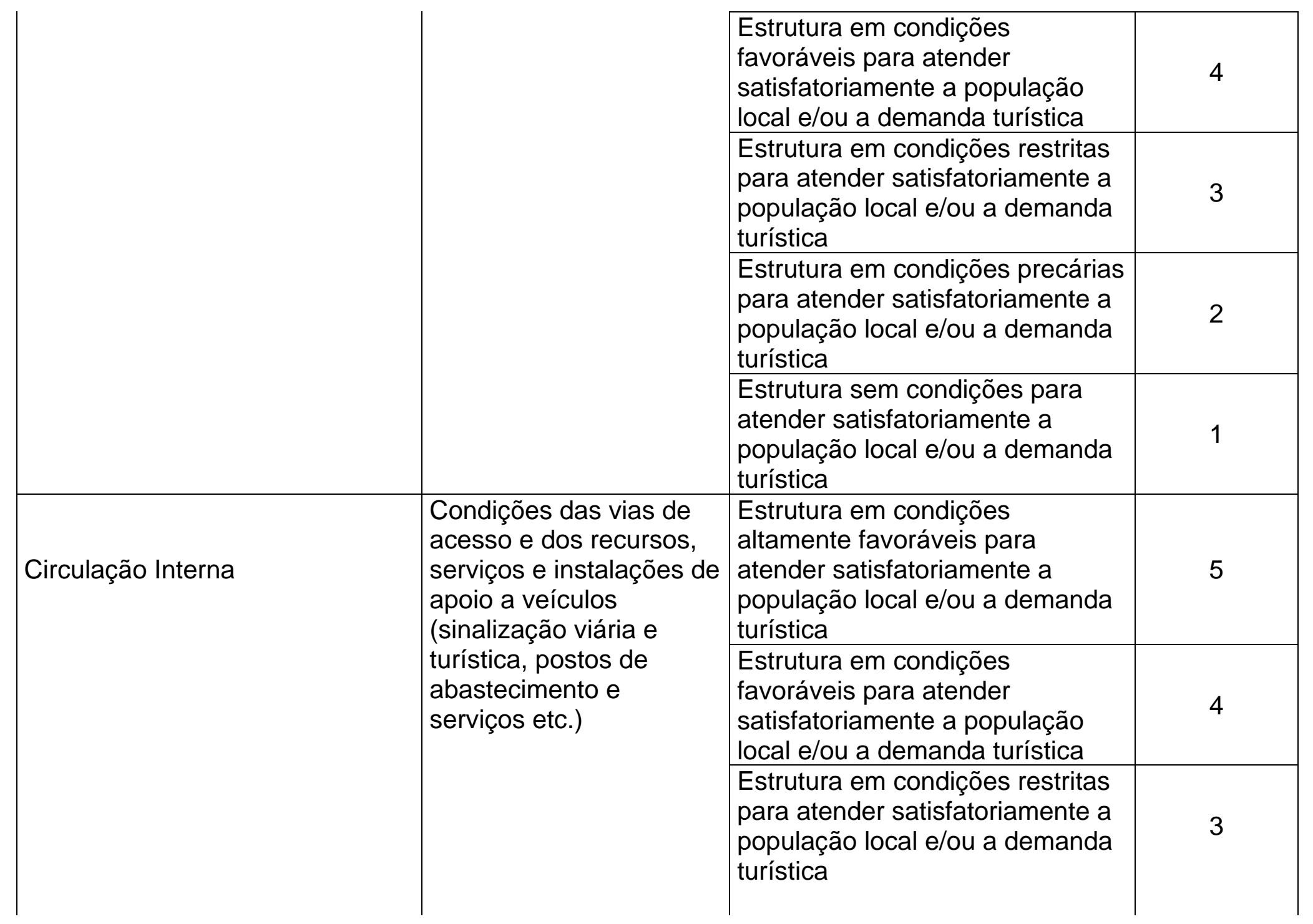




\begin{tabular}{|c|c|c|c|}
\hline & & $\begin{array}{l}\text { Estrutura em condições precárias } \\
\text { para atender satisfatoriamente a } \\
\text { população local e/ou a demanda } \\
\text { turística }\end{array}$ & 2 \\
\hline & & $\begin{array}{l}\text { Estrutura sem condições para } \\
\text { atender satisfatoriamente a } \\
\text { população local e/ou a demanda } \\
\text { turística }\end{array}$ & 1 \\
\hline \multirow{5}{*}{ Sistema de Transportes } & \multirow{5}{*}{$\begin{array}{l}\text { Estrutura e qualidade } \\
\text { dos serviços }\end{array}$} & $\begin{array}{l}\text { Estrutura em condições } \\
\text { altamente favoráveis para } \\
\text { atender satisfatoriamente a } \\
\text { população local e/ou a demanda } \\
\text { turística }\end{array}$ & 5 \\
\hline & & $\begin{array}{l}\text { Estrutura em condições } \\
\text { favoráveis para atender } \\
\text { satisfatoriamente a população } \\
\text { local e/ou a demanda turística }\end{array}$ & 4 \\
\hline & & $\begin{array}{l}\text { Estrutura em condições restritas } \\
\text { para atender satisfatoriamente a } \\
\text { população local e/ou a demanda } \\
\text { turística }\end{array}$ & 3 \\
\hline & & $\begin{array}{l}\text { Estrutura em condições precárias } \\
\text { para atender satisfatoriamente a } \\
\text { população local e/ou a demanda } \\
\text { turística }\end{array}$ & 2 \\
\hline & & $\begin{array}{l}\text { Estrutura sem condições para } \\
\text { atender satisfatoriamente a } \\
\text { população local e/ou a demanda } \\
\text { turística }\end{array}$ & 1 \\
\hline
\end{tabular}




\begin{tabular}{|c|c|c|c|}
\hline \multirow{5}{*}{ Sistema de Comunicações } & \multirow{5}{*}{$\begin{array}{l}\text { Estrutura e qualidade } \\
\text { dos serviços }\end{array}$} & $\begin{array}{l}\text { Estrutura em condições } \\
\text { altamente favoráveis para } \\
\text { atender satisfatoriamente a } \\
\text { população local e/ou a demanda } \\
\text { turística }\end{array}$ & 5 \\
\hline & & $\begin{array}{l}\text { Estrutura em condições } \\
\text { favoráveis para atender } \\
\text { satisfatoriamente a população } \\
\text { local e/ou a demanda turística }\end{array}$ & 4 \\
\hline & & $\begin{array}{l}\text { Estrutura em condições restritas } \\
\text { para atender satisfatoriamente a } \\
\text { população local e/ou a demanda } \\
\text { turística }\end{array}$ & 3 \\
\hline & & $\begin{array}{l}\text { Estrutura em condições precárias } \\
\text { para atender satisfatoriamente a } \\
\text { população local e/ou a demanda } \\
\text { turística }\end{array}$ & 2 \\
\hline & & $\begin{array}{l}\text { Estrutura sem condições para } \\
\text { atender satisfatoriamente a } \\
\text { população local e/ou a demanda } \\
\text { turística }\end{array}$ & 1 \\
\hline \multirow[t]{2}{*}{ Sistema de Segurança } & \multirow[t]{2}{*}{$\begin{array}{l}\text { Estrutura e qualidade } \\
\text { dos serviços }\end{array}$} & $\begin{array}{l}\text { Estrutura em condições } \\
\text { altamente favoráveis para } \\
\text { atender satisfatoriamente a } \\
\text { população local e/ou a demanda } \\
\text { turística }\end{array}$ & 5 \\
\hline & & $\begin{array}{l}\text { Estrutura em condições } \\
\text { favoráveis para atender } \\
\text { satisfatoriamente a população } \\
\text { local e/ou a demanda turística }\end{array}$ & 4 \\
\hline
\end{tabular}




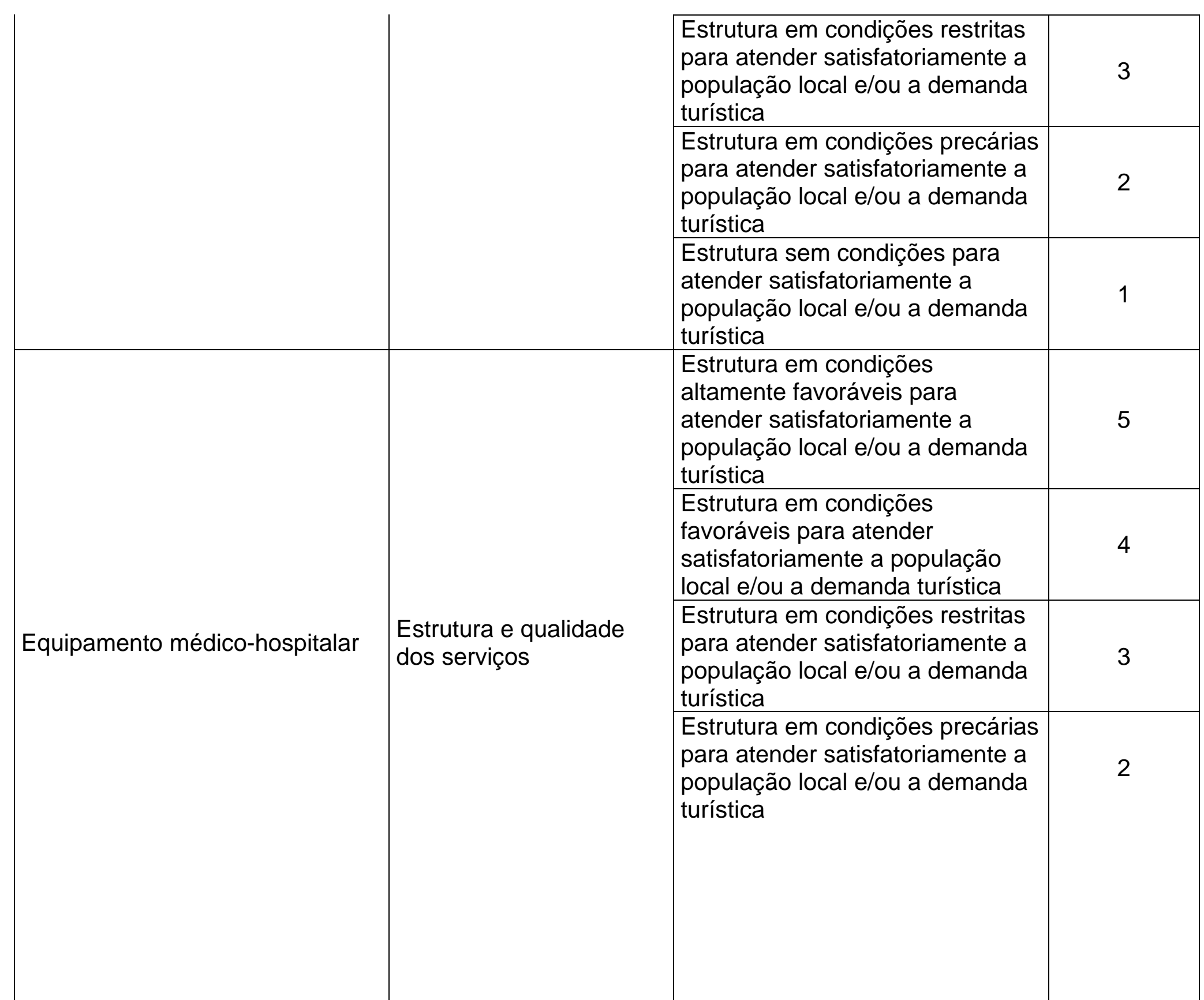




\begin{tabular}{|c|c|c|c|c|}
\hline & & & $\begin{array}{l}\text { Estrutura sem condições para } \\
\text { atender satisfatoriamente a } \\
\text { população local e/ou a demanda } \\
\text { turística }\end{array}$ & 1 \\
\hline \multirow[t]{8}{*}{$\begin{array}{l}\text { Normativo- } \\
\text { institucional }\end{array}$} & \multirow[t]{8}{*}{ Estrutura } & \multirow{5}{*}{$\begin{array}{l}\text { Existência e atuação do } \\
\text { órgão oficial de turismo }\end{array}$} & $\begin{array}{l}\text { Órgão oficial municipal altamente } \\
\text { atuante quanto ao planejamento } \\
\text { e desenvolvimento do turismo }\end{array}$ & 5 \\
\hline & & & $\begin{array}{l}\text { Órgão oficial municipal atuante } \\
\text { de forma satisfatória quanto ao } \\
\text { planejamento e desenvolvimento } \\
\text { do turismo }\end{array}$ & 4 \\
\hline & & & $\begin{array}{l}\text { Órgão oficial municipal atuante } \\
\text { de forma limitada quanto ao } \\
\text { planejamento e desenvolvimento } \\
\text { do turismo }\end{array}$ & 3 \\
\hline & & & $\begin{array}{l}\text { Órgão oficial municipal pouco } \\
\text { atuante quanto ao planejamento } \\
\text { e desenvolvimento do turismo }\end{array}$ & 2 \\
\hline & & & $\begin{array}{l}\text { Inexistência de órgão oficial } \\
\text { municipal de turismo }\end{array}$ & - \\
\hline & & \multirow[t]{3}{*}{$\begin{array}{l}\text { Existência e atuação do } \\
\text { conselho municipal de } \\
\text { turismo }\end{array}$} & $\begin{array}{l}\text { Conselho municipal de turismo } \\
\text { altamente atuante quanto ao } \\
\text { planejamento e desenvolvimento } \\
\text { do turismo }\end{array}$ & 5 \\
\hline & & & $\begin{array}{l}\text { Conselho municipal de turismo } \\
\text { atuante de forma satisfatória } \\
\text { quanto ao planejamento e } \\
\text { desenvolvimento do turismo }\end{array}$ & 4 \\
\hline & & & $\begin{array}{l}\text { Conselho municipal de turismo } \\
\text { atuante de forma limitada quanto } \\
\text { ao planejamento e } \\
\text { desenvolvimento do turismo }\end{array}$ & 3 \\
\hline
\end{tabular}




\begin{tabular}{|c|c|c|}
\hline & $\begin{array}{l}\text { Conselho municipal de turismo } \\
\text { pouco atuante quanto ao } \\
\text { planejamento e desenvolvimento } \\
\text { do turismo }\end{array}$ & 2 \\
\hline & $\begin{array}{l}\text { Inexistência de conselho } \\
\text { municipal de turismo }\end{array}$ & - \\
\hline \multirow{3}{*}{$\begin{array}{l}\text { Existência e gestão do } \\
\text { fundo municipal de } \\
\text { turismo }\end{array}$} & $\begin{array}{l}\text { Fundo municipal de turismo } \\
\text { oficialmente criado e com } \\
\text { disponibilidade de recursos para } \\
\text { investimentos nas ações de } \\
\text { planejamento e/ou } \\
\text { desenvolvimento do turismo }\end{array}$ & 5 \\
\hline & $\begin{array}{l}\text { Fundo municipal de turismo } \\
\text { oficialmente criado, sem recursos } \\
\text { disponíveis para investimentos } \\
\text { nas ações de planejamento e/ou } \\
\text { desenvolvimento do turismo }\end{array}$ & 3 \\
\hline & $\begin{array}{l}\text { Inexistência de fundo municipal } \\
\text { de turismo }\end{array}$ & - \\
\hline \multirow[t]{2}{*}{$\begin{array}{l}\text { Existência e atuação de } \\
\text { outras organizações não } \\
\text { governamentais de } \\
\text { fomento e promoção do } \\
\text { turismo }\end{array}$} & $\begin{array}{l}\text { Organizações não } \\
\text { governamentais de âmbito } \\
\text { municipal altamente atuantes } \\
\text { quanto ao planejamento e/ou } \\
\text { desenvolvimento do turismo }\end{array}$ & 5 \\
\hline & $\begin{array}{l}\text { Organizações não } \\
\text { governamentais de âmbito } \\
\text { municipal atuantes de forma } \\
\text { satisfatória quanto ao } \\
\text { planejamento e/ou } \\
\text { desenvolvimento do turismo }\end{array}$ & 4 \\
\hline
\end{tabular}




\begin{tabular}{|c|c|c|c|}
\hline & & $\begin{array}{l}\text { Organizações não } \\
\text { governamentais de âmbito } \\
\text { municipal atuantes de forma } \\
\text { limitada quanto ao planejamento } \\
\text { e/ou desenvolvimento do turismo }\end{array}$ & 3 \\
\hline & & $\begin{array}{l}\text { Organizações não } \\
\text { governamentais de âmbito } \\
\text { municipal pouco atuantes quanto } \\
\text { ao planejamento e/ou } \\
\text { desenvolvimento do turismo } \\
\end{array}$ & 2 \\
\hline & & $\begin{array}{l}\text { Inexistência de organizações não } \\
\text { governamentais de âmbito } \\
\text { municipal atuantes quanto ao } \\
\text { planejamento e/ou } \\
\text { desenvolvimento do turismo }\end{array}$ & - \\
\hline \multirow[t]{5}{*}{$\begin{array}{l}\text { Instrumentos de planejamento e } \\
\text { gestão pública e compartilhada } \\
\text { do turismo }\end{array}$} & \multirow{3}{*}{$\begin{array}{l}\text { Existência de plano de } \\
\text { desenvolvimento } \\
\text { turístico/plano diretor de } \\
\text { turismo em vigor }\end{array}$} & $\begin{array}{l}\text { Plano municipal de turismo } \\
\text { oficialmente criado e em } \\
\text { implantação }\end{array}$ & 5 \\
\hline & & $\begin{array}{l}\text { Plano municipal de turismo } \\
\text { oficialmente criado, mas ainda } \\
\text { não implantado (total ou } \\
\text { parcialmente), ou em fase de } \\
\text { elaboração }\end{array}$ & 3 \\
\hline & & $\begin{array}{l}\text { Inexistência de plano municipal } \\
\text { de turismo }\end{array}$ & - \\
\hline & \multirow{2}{*}{$\begin{array}{l}\text { Existência de legislação } \\
\text { turística, urbana, } \\
\text { ambiental e/ou de } \\
\text { proteção ao patrimônio e } \\
\text { de mecanismos de } \\
\text { fiscalização do } \\
\text { cumprimento da } \\
\text { legislação }\end{array}$} & $\begin{array}{l}\text { Legislação municipal existente e } \\
\text { em vigor }\end{array}$ & 5 \\
\hline & & $\begin{array}{l}\text { Legislação municipal existente, } \\
\text { mas ainda não em vigor, ou em } \\
\text { fase de elaboração }\end{array}$ & 3 \\
\hline
\end{tabular}




\begin{tabular}{|c|c|c|}
\hline & Legislação municipal inexistente & - \\
\hline \multirow{3}{*}{$\begin{array}{l}\text { Existência de créditos } \\
\text { e/ou de incentivos fiscais } \\
\text { ao desenvolvimento } \\
\text { turístico }\end{array}$} & $\begin{array}{l}\text { Créditos e/ou incentivos fiscais } \\
\text { ao desenvolvimento turístico } \\
\text { municipal oficialmente existentes } \\
\text { e disponíveis aos interessados }\end{array}$ & 5 \\
\hline & $\begin{array}{l}\text { Créditos e/ou incentivos fiscais } \\
\text { ao desenvolvimento turístico } \\
\text { municipal oficialmente existentes } \\
\text { mas ainda não disponíveis aos } \\
\text { interessados, ou em fase de } \\
\text { disponibilização } \\
\end{array}$ & 3 \\
\hline & $\begin{array}{l}\text { Créditos e/ou incentivos fiscais } \\
\text { ao desenvolvimento turístico } \\
\text { municipal inexistentes }\end{array}$ & - \\
\hline \multirow{3}{*}{$\begin{array}{l}\text { Inserção do município } \\
\text { em planos, programas } \\
\text { e/ou projetos de } \\
\text { desenvolvimento } \\
\text { turístico de âmbito } \\
\text { estadual, regional e/ou } \\
\text { nacional }\end{array}$} & $\begin{array}{l}\text { Participação oficial efetiva do } \\
\text { município }\end{array}$ & 5 \\
\hline & $\begin{array}{l}\text { Participação do município } \\
\text { oficialmente estabelecida mas } \\
\text { ainda não efetiva }\end{array}$ & 3 \\
\hline & $\begin{array}{l}\text { Ausência de participação oficial } \\
\text { do município }\end{array}$ & - \\
\hline \multirow{3}{*}{$\begin{array}{l}\text { Possibilidade de } \\
\text { integração do município } \\
\text { em roteiros e/ou circuitos }\end{array}$} & $\begin{array}{l}\text { Integração oficial efetiva do } \\
\text { município }\end{array}$ & 5 \\
\hline & $\begin{array}{l}\text { Integração do município } \\
\text { oficialmente estabelecida mas } \\
\text { ainda não efetiva }\end{array}$ & 3 \\
\hline & $\begin{array}{l}\text { Ausência de integração oficial do } \\
\text { município }\end{array}$ & - \\
\hline
\end{tabular}




\begin{tabular}{|c|c|c|c|c|}
\hline & & \multirow{3}{*}{ Ações de divulgação } & $\begin{array}{l}\text { Divulgação efetiva do município } \\
\text { por parte do órgão oficial de } \\
\text { turismo e/ou de organizações } \\
\text { não governamentais de âmbito } \\
\text { municipal atuantes quanto ao } \\
\text { planejamento e/ou } \\
\text { desenvolvimento do turismo }\end{array}$ & 5 \\
\hline & & & $\begin{array}{l}\text { Divulgação limitada do município } \\
\text { por parte do órgão oficial de } \\
\text { turismo ou de organizações não } \\
\text { governamentais de âmbito } \\
\text { municipal atuantes quanto ao } \\
\text { planejamento e/ou } \\
\text { desenvolvimento do turismo }\end{array}$ & 3 \\
\hline & & & $\begin{array}{l}\text { Ausência de divulgação do } \\
\text { município por parte do órgão } \\
\text { oficial de turismo e/ou de } \\
\text { organizações não } \\
\text { governamentais de âmbito } \\
\text { municipal atuantes quanto ao } \\
\text { planejamento e/ou } \\
\text { desenvolvimento do turismo }\end{array}$ & - \\
\hline $\begin{array}{l}\text { Planejamento } \\
\text { turístico } \\
\text { participativo }\end{array}$ & Participação comunitária & $\begin{array}{l}\text { Nível de envolvimento e } \\
\text { aceitação da } \\
\text { comunidade local nos } \\
\text { processos de }\end{array}$ & $\begin{array}{l}\text { Elevado nível de envolvimento e } \\
\text { aceitação da comunidade local } \\
\text { nos processos de planejamento } \\
\text { e/ou desenvolvimento do turismo }\end{array}$ & 5 \\
\hline & & $\begin{array}{l}\text { planejamento e/ou } \\
\text { desenvolvimento do } \\
\text { turismo }\end{array}$ & $\begin{array}{l}\text { Nível satisfatório de envolvimento } \\
\text { e aceitação da comunidade local } \\
\text { nos processos de planejamento } \\
\text { e/ou desenvolvimento do turismo }\end{array}$ & 4 \\
\hline
\end{tabular}




\begin{tabular}{|c|c|c|c|c|}
\hline & & & $\begin{array}{l}\text { Limitado nível de envolvimento } \\
\text { e/ou aceitação da comunidade } \\
\text { local nos processos de } \\
\text { planejamento e/ou } \\
\text { desenvolvimento do turismo }\end{array}$ & 3 \\
\hline & & & $\begin{array}{l}\text { Baixo nível de envolvimento e/ou } \\
\text { aceitação da comunidade local } \\
\text { nos processos de planejamento } \\
\text { e/ou desenvolvimento do turismo }\end{array}$ & 2 \\
\hline & & & $\begin{array}{l}\text { Inexistência de envolvimento } \\
\text { e/ou aceitação da comunidade } \\
\text { local nos processos de } \\
\text { planejamento e/ou } \\
\text { desenvolvimento do turismo } \\
\end{array}$ & - \\
\hline \multirow[t]{13}{*}{ Outros fatores } & \multirow{5}{*}{ Proximidade da demanda } & \multirow{5}{*}{$\begin{array}{l}\text { Distância dos principais } \\
\text { centro emissores } \\
\text { regionais }\end{array}$} & Inferior a $100 \mathrm{~km}$ & 5 \\
\hline & & & De 100 km a 200 km & 4 \\
\hline & & & De 200 km a 300 km & 3 \\
\hline & & & De 300 km a 400 km & 2 \\
\hline & & & Acima de $400 \mathrm{~km}$ & 1 \\
\hline & \multirow{5}{*}{$\begin{array}{l}\text { Disponibilidade de áreas para } \\
\text { expansão }\end{array}$} & \multirow{5}{*}{$\begin{array}{l}\text { Existência de áreas para } \\
\text { expansão dos atrativos } \\
\text { e/ou dos equipamentos } \\
\text { turísticos }\end{array}$} & $\begin{array}{l}\text { Existente em quantidade e } \\
\text { qualidade adequadas }\end{array}$ & 5 \\
\hline & & & $\begin{array}{l}\text { Existente em quantidade e } \\
\text { qualidade aceitáveis }\end{array}$ & 4 \\
\hline & & & Limitada & 3 \\
\hline & & & $\begin{array}{l}\text { Escassa, com custos adicionais } \\
\text { consideráveis }\end{array}$ & 2 \\
\hline & & & Praticamente inexistentes & 1 \\
\hline & \multirow[t]{3}{*}{ Disponibilidade de mão-de-obra } & \multirow{3}{*}{$\begin{array}{l}\text { Existência de mão-de- } \\
\text { obra em quantidade e } \\
\text { qualidade para } \\
\text { atendimento ao turista }\end{array}$} & $\begin{array}{l}\text { Existente em quantidade e } \\
\text { qualidade adequadas }\end{array}$ & 5 \\
\hline & & & $\begin{array}{l}\text { Existente em quantidade e } \\
\text { qualidade aceitáveis }\end{array}$ & 4 \\
\hline & & & Limitada & 3 \\
\hline
\end{tabular}


Escassa, com custos adicionais

consideráveis

Praticamente inexistente

Quadro 20 - Matriz de Avaliação do Potencial Turístico de Localidades Receptoras Fonte: elaborado pelo autor. 
A proposta supra inclui-se, segundo a classificação de Smith (1992, p.19-49), dentre os métodos e técnicas de investigação descritiva de lugares, mais especificamente, na categoria dos métodos separativos de inventário de recursos e, segundo Leno Cerro (1993, p.53-136), consiste em uma avaliação analítica do potencial turístico, conforme descrito no capítulo 1 desta tese.

Isto posto, cabe agora analisar a validade do instrumento proposto nos municípios paulistas escolhidos para tal finalidade - Guaratinguetá e Cunha.

\subsection{Aplicação da Matriz de Avaliação do Potencial Turístico de Localidades Receptoras aos Municípios de Guaratinguetá e Cunha}

A fim de possibilitar o preenchimento da matriz apresentada acima com os dados dos municípios escolhidos, utilizou-se fundamentalmente, como fonte de informações, o banco de dados mencionado no item 2.2 desta tese.

A este respeito, convém explicitar que, embora este banco de dados não tenha sido elaborado para fins de planejamento turístico de destinações, mas sim para a roteirização, com foco não em atrativos, mas sim na possibilidade da realização de atividades por parte dos turistas - o que pode ser particularmente interessante para este trabalho ao diferir ligeiramente da maior parte dos métodos encontrados na literatura e ao contribuir para expressar melhor a potencialidade -, existe certa coincidência com a metodologia de inventário do CICATUR/OEA, o que explica a adoção de tal fonte de informações. 
Além disso, os dados inexistentes no banco de dados resultante da Rede de Cooperação Técnica para a Roteirização, considerados indispensáveis para este estudo foram buscados em outras fontes, a fim de propiciar uma adequada avaliação dos referidos municípios.

Assim, observam-se em seguida os elementos avaliados nos municípios de Guaratinguetá e Cunha, de acordo com a matriz proposta, e suas respectivas pontuações, atribuídas com base no conhecimento obtido pelo autor através das visitas in loco e da pesquisa de dados secundários realizada em guias turísticos, publicações específicas dos municípios, material promocional e sites da internet.

Uma explicação adicional sobre a atribuição da pontuação aos atrativos turísticos faz-se necessária: conforme já mencionado anteriormente, tais critérios seguiram a proposta de Leno Cerro (1993, p.48), que acrescenta um nível à hierarquização estabelecida pelo CICATUR/OEA; todavia, não foram feitos os cálculos que conduzem a tal resultado - acredita-se que a experiência prática do autor seja suficiente, aqui, para atribuir tais pontuações para efeito de teste do instrumento como um todo (do qual a hierarquização dos atrativos é apenas uma parte, tendo, pois, sua importância relativizada).

Por fim, com base nos resultados obtidos através de análise dos vários aspectos listados anteriormente em cada um dos municípios, foram efetuadas as somatórias dos resultados por indicadores, categorias e dimensões, que possibilitarão, no subcapítulo seguinte, a discussão dos resultados. 


\begin{tabular}{|c|c|c|c|c|}
\hline Dimensões & Categorias de Análise & Indicadores & Aspectos Analisados & Pontuação \\
\hline \multirow[t]{28}{*}{ Atrativos turísticos } & \multirow{10}{*}{$\begin{array}{l}\text { Naturais (e seus respectivos tipos e } \\
\text { subtipos) }\end{array}$} & \multirow{10}{*}{ Hierarquia dos atrativos } & Serra da Mantiqueira & 3 \\
\hline & & & Serra Quebra-Cangalha & 3 \\
\hline & & & Ribeirão Gomeral & 1 \\
\hline & & & Ribeirão Taquaral & 1 \\
\hline & & & Ribeirão das Pedrinhas & 1 \\
\hline & & & Barragem do Mottas & 1 \\
\hline & & & Queda d'água Gomeral & 2 \\
\hline & & & Pico (Bairro das Pedrinhas) & 2 \\
\hline & & & Estrada Parque José Jorge Boueri & 2 \\
\hline & & & SUBTOTAL - NATURAIS & 16 \\
\hline & \multirow{18}{*}{$\begin{array}{l}\text { Histórico-culturais (e seus } \\
\text { respectivos tipos e subtipos) }\end{array}$} & \multirow[t]{18}{*}{ Hierarquia dos atrativos } & Caixa d'água da Colônia Piagui & 1 \\
\hline & & & Catedral de Santo Antônio & 3 \\
\hline & & & Gruta de Nossa Senhora de Lourdes & 2 \\
\hline & & & Casa de Frei Galvão & 3 \\
\hline & & & Seminário Frei Galvão & 2 \\
\hline & & & $\begin{array}{l}\text { Igreja do Convento Franciscano de } \\
\text { Nossa Senhora das Graças }\end{array}$ & 2 \\
\hline & & & $\begin{array}{l}\text { Capela do Colégio Nossa Senhora } \\
\text { do Carmo }\end{array}$ & 1 \\
\hline & & & Mosteiro da Imaculada Conceição & 1 \\
\hline & & & Igreja Matriz de Santo Expedito & 1 \\
\hline & & & Igreja de Santa Rita & 2 \\
\hline & & & Igreja de São Benedito & 2 \\
\hline & & & $\begin{array}{l}\text { Prédio da Associação Comercial e } \\
\text { Industrial de Guaratinguetá }\end{array}$ & 1 \\
\hline & & & Escola Estadual Dr. Flamínio Lessa & 1 \\
\hline & & & $\begin{array}{l}\text { Escola Estadual Cons. Rodrigues } \\
\text { Alves }\end{array}$ & 1 \\
\hline & & & Estação da Estrada de Ferro & 1 \\
\hline & & & Solar Rangel de Camargo & 1 \\
\hline & & & $\begin{array}{l}\text { Museu Histórico e Pedagógico } \\
\text { Cons. Rodrigues Alves }\end{array}$ & 2 \\
\hline & & & Prédio da Prefeitura Municipal & 1 \\
\hline
\end{tabular}




\begin{tabular}{|c|c|c|c|}
\hline & & $\begin{array}{l}\text { Marco histórico da Revolução } \\
\text { Constitucionalista }\end{array}$ & 1 \\
\hline & & $\begin{array}{l}\text { Escola de Enfermagem Dr. Benedito } \\
\text { Meirelles }\end{array}$ & 1 \\
\hline & & Aqueduto da Fazenda Esperança & 1 \\
\hline & & Instituto Nossa Senhora do Carmo & 1 \\
\hline & & $\begin{array}{l}\text { Escola Estadual Prof. Flamínio } \\
\text { Lessa }\end{array}$ & 1 \\
\hline & & Museu Frei Galvão & 2 \\
\hline & & Mercado Municipal & 1 \\
\hline & & SUBTOTAL - HISTÓRICO & 36 \\
\hline \multirow{2}{*}{$\begin{array}{l}\text { Manifestações e usos tradicionais e } \\
\text { populares (e seus respectivos tipos } \\
\text { e subtipos) }\end{array}$} & \multirow[t]{2}{*}{ Hierarquia dos atrativos } & $\begin{array}{l}\text { Artesanato - fundição de ferro e } \\
\text { bronze }\end{array}$ & 2 \\
\hline & & SUBTOTAL - MANIFESTAÇÕES & 2 \\
\hline \multirow{2}{*}{$\begin{array}{l}\text { Realizações técnicas e científicas } \\
\text { contemporâneas (e seus respectivos } \\
\text { tipos e subtipos) }\end{array}$} & \multirow[t]{2}{*}{ Hierarquia dos atrativos } & $\begin{array}{l}\text { Escola de Especialistas da } \\
\text { Aeronáutica }\end{array}$ & 3 \\
\hline & & SUBTOTAL - REALIZAÇÕES & 3 \\
\hline \multirow{14}{*}{$\begin{array}{l}\text { Acontecimentos programados (e } \\
\text { seus respectivos tipos e subtipos) }\end{array}$} & \multirow[t]{14}{*}{ Hierarquia dos atrativos } & Carnaval & 3 \\
\hline & & Semana Santa & 2 \\
\hline & & Festa de São Benedito & 2 \\
\hline & & Jogos Universitários & 2 \\
\hline & & $\begin{array}{l}\text { Campeonato Intermunicipal de } \\
\text { Futebol Feminino }\end{array}$ & 1 \\
\hline & & Semana da Cultura Negra & 1 \\
\hline & & Festa de São Benedito & 2 \\
\hline & & Aniversário do Município & 1 \\
\hline & & Festa do Padroeiro (Santo Antônio) & 2 \\
\hline & & $\begin{array}{l}\text { Salão Nacional de Artes Prof. } \\
\text { Ernesto Quissak }\end{array}$ & 3 \\
\hline & & Festas Juninas e Julinas & 2 \\
\hline & & Corrida Pedestre & 1 \\
\hline & & $\begin{array}{l}\text { Semana do Pres. Cons. Rodrigues } \\
\text { Alves }\end{array}$ & 2 \\
\hline & & Undokay & 2 \\
\hline
\end{tabular}




\begin{tabular}{|c|c|c|c|c|}
\hline & & & Semana da Pátria & 1 \\
\hline & & & $\begin{array}{l}\text { Festival Nacional de Violão } \\
\text { Dilermando Reis }\end{array}$ & 3 \\
\hline & & & Raid Búfalos do Vale & 3 \\
\hline & & & Festa do Beato Frei Galvão & 3 \\
\hline & & & Semana Brito Broca & 1 \\
\hline & & & Salão de Artes Fotográficas & 2 \\
\hline & & & Semana Bonfiglio de Oliveira & 1 \\
\hline & & & $\begin{array}{l}\text { Exposição Nacional do Cão Fila } \\
\text { Brasileiro - Expofila }\end{array}$ & 3 \\
\hline & & & Eventos Natalinos & 1 \\
\hline & & & Feira da APAE & 2 \\
\hline & & & SUBTOTAL - ACONTECIMENTOS & 46 \\
\hline & \multicolumn{3}{|c|}{ SUBTOTAL - ATRATIVOS TURÍSTICOS } & 103 \\
\hline \multirow[t]{18}{*}{$\begin{array}{l}\text { Equipamentos e } \\
\text { serviços turísticos }\end{array}$} & \multirow{13}{*}{$\begin{array}{l}\text { Meios de hospedagem - } \\
\text { estabelecimentos hoteleiros }\end{array}$} & \multirow{6}{*}{$\begin{array}{l}\text { Estrutura dos } \\
\text { equipamentos }\end{array}$} & $\begin{array}{l}\text { Hotel Fazenda Clube dos } \\
\text { Quinhentos }\end{array}$ & 5 \\
\hline & & & Hotel Fazenda Alvorada & ND \\
\hline & & & Hotel Kafé & 5 \\
\hline & & & Hotel Patury & 5 \\
\hline & & & Hotel Fazenda Rancho Sete Lagos & 5 \\
\hline & & & SUBTOTAL - ESTRUTURA & 20 \\
\hline & & \multirow{6}{*}{$\begin{array}{l}\text { Qualidade dos } \\
\text { equipamentos e serviços }\end{array}$} & $\begin{array}{l}\text { Hotel Fazenda Clube dos } \\
\text { Quinhentos }\end{array}$ & 3 \\
\hline & & & Hotel Fazenda Alvorada & ND \\
\hline & & & Hotel Kafé & 4 \\
\hline & & & Hotel Patury & 3 \\
\hline & & & Hotel Fazenda Rancho Sete Lagos & 4 \\
\hline & & & SUBTOTAL - QUALIDADE & 14 \\
\hline & & \multicolumn{2}{|l|}{ SUBTOTAL - HOTELEIROS } & 34 \\
\hline & \multirow{5}{*}{$\begin{array}{l}\text { Meios de Hospedagem - } \\
\text { estabelecimentos extra-hoteleiros }\end{array}$} & \multirow{5}{*}{$\begin{array}{l}\text { Estrutura dos } \\
\text { equipamentos }\end{array}$} & Pousada Praia das Pedrinhas & 2 \\
\hline & & & Pousada Monte Verde & 2 \\
\hline & & & Pathernon Flats & 5 \\
\hline & & & Del Vale Residence Avenue & 4 \\
\hline & & & Camping Clube do Brasil & 5 \\
\hline
\end{tabular}




\begin{tabular}{|l}
\hline \\
Qualidade dos \\
equipamentos e serviços
\end{tabular}

SUBTOTAL - ESTRUTURA

Pousada Praia das Pedrinhas

Pousada Monte Verde

Pathernon Flats

Del Vale Residence Avenue

Camping Clube do Brasil

SUBTOTAL - QUALIDADE

SUBTOTAL - EXTRA-HOTELEIROS

Alimentação

Choperia Cobrinha

Comercial DIP Auto Posto

Serve Quente Fast Food

Buffet Jolimar Doceria

Delamare

Porco Chorão

Choperia Ganisa

Mais Sabor Pizzaria

Cappio Sorveteria

Churrascaria da Serra

Estrutura dos

equipamentos

Restaurante Esperança

Mirian's Fast Food e Doceria

Churrascaria Minuano

Grill Picanha na Tábua

Terraço Pizzaria

Restaurante Delícia

Clube dos 500

Patury

Pizza 1

Pizza Nostra

Pizzaria Danutti

Augusto Pizzaria e Choperia

SUBTOTAL - ESTRUTURA

Qualidade dos

equipamentos, serviços e

produtos

Choperia Cobrinha

Comercial DIP Auto Posto

Serve Quente Fast Food

18

\begin{tabular}{|c|c|}
\hline & 18 \\
\hline & 3 \\
\hline & 2 \\
\hline & 5 \\
\hline & 4 \\
\hline & 18 \\
\hline
\end{tabular}




\begin{tabular}{|c|c|c|c|c|}
\hline & & & Buffet Jolimar Doceria & 2 \\
\hline & & & Delamare & 3 \\
\hline & & & Porco Chorão & 3 \\
\hline & & & Choperia Ganisa & 4 \\
\hline & & & Mais Sabor Pizzaria & 3 \\
\hline & & & Cappio Sorveteria & 2 \\
\hline & & & Churrascaria da Serra & 4 \\
\hline & & & Restaurante Esperança & 4 \\
\hline & & & Mirian's Fast Food e Doceria & 3 \\
\hline & & & Churrascaria Minuano & 4 \\
\hline & & & Grill Picanha na Tábua & 5 \\
\hline & & & Terraço Pizzaria & 4 \\
\hline & & & Restaurante Delícia & 4 \\
\hline & & & Clube dos 500 & 4 \\
\hline & & & Patury & 5 \\
\hline & & & Pizza 1 & 4 \\
\hline & & & Pizza Nostra & 3 \\
\hline & & & Pizzaria Danutti & 3 \\
\hline & & & Augusto Pizzaria e Choperia & 4 \\
\hline & & & SUBTOTAL - QUALIDADE & 77 \\
\hline & & SUBTOTAL - ALIMENTA & & 174 \\
\hline & & Fstrutura/gualidade dos & Clube de Campo Pedrinhas & 2 \\
\hline & $\begin{array}{l}\text { Entretenimentos (e seus respectivos } \\
\text { tipos e subtipos) }\end{array}$ & $\begin{array}{l}\text { Estrutura/qualldade dos } \\
\text { equipamentos e serviços }\end{array}$ & $\begin{array}{l}\text { Balneário Parque Águas da } \\
\text { Mantiqueira }\end{array}$ & 2 \\
\hline & & SUBTOTAL - ENTRETEN & IENTOS & 4 \\
\hline & Outros serviços turísticos (e seus & $\begin{array}{l}\text { Estrutura/qualidade dos } \\
\text { equipamentos e serviços }\end{array}$ & Accetur Agência Receptiva & 3 \\
\hline & & SUBTOTAL - OUTROS S & ZVIÇOS & 3 \\
\hline & SUBTOTAL - DIMENSÃO EQUIPAM & ENTOS E SERVIÇOS TUR & TICOS & 251 \\
\hline $\begin{array}{l}\text { Infra-estrutura de } \\
\text { apoio turístico }\end{array}$ & $\begin{array}{l}\text { Serviços urbanos (abastecimento de } \\
\text { água, rede de esgotos, limpeza } \\
\text { pública, e energia elétrica) }\end{array}$ & $\begin{array}{l}\text { Estrutura e qualidade dos } \\
\text { serviços }\end{array}$ & & 4 \\
\hline
\end{tabular}




\begin{tabular}{|c|c|c|c|c|}
\hline & Acesso rodoviário à localidade & $\begin{array}{l}\text { Condições das vias de } \\
\text { acesso e dos recursos, } \\
\text { serviços e instalações de } \\
\text { apoio a veículos } \\
\text { (sinalização rodoviária e } \\
\text { turística, postos de } \\
\text { abastecimento e serviços } \\
\text { etc.) }\end{array}$ & & 5 \\
\hline & Circulação Interna & $\begin{array}{l}\text { Condições das vias de } \\
\text { acesso e dos recursos, } \\
\text { serviços e instalações de } \\
\text { apoio a veículos } \\
\text { (sinalização viária e } \\
\text { turística, postos de } \\
\text { abastecimento e serviços } \\
\text { etc.) }\end{array}$ & & 5 \\
\hline & Sistema de Transportes & $\begin{array}{l}\text { Estrutura e qualidade dos } \\
\text { serviços }\end{array}$ & & 5 \\
\hline & Sistema de Comunicações & $\begin{array}{l}\text { Estrutura e qualidade dos } \\
\text { serviços }\end{array}$ & & 5 \\
\hline & Sistema de Segurança & $\begin{array}{l}\text { Estrutura e qualidade dos } \\
\text { serviços }\end{array}$ & & 5 \\
\hline & Equipamento médico-hospitalar & $\begin{array}{l}\text { Estrutura e qualidade dos } \\
\text { serviços }\end{array}$ & & 5 \\
\hline & SUBTOTAL - DIMENSÃO INFR & TRUTURA DE APOIO TURÍ & TICO & 34 \\
\hline $\begin{array}{l}\text { Normativo- } \\
\text { institucional }\end{array}$ & Estrutura & $\begin{array}{l}\text { Existência e atuação do } \\
\text { órgão oficial de turismo }\end{array}$ & Secretaria de Esportes e Turismo & 3 \\
\hline & & $\begin{array}{l}\text { Existência e atuação do } \\
\text { conselho municipal de } \\
\text { turismo }\end{array}$ & - & - \\
\hline & & $\begin{array}{l}\text { Existência e gestão do } \\
\text { fundo municipal de turismo }\end{array}$ & - & - \\
\hline & & $\begin{array}{l}\text { Existência e atuação de } \\
\text { outras organizações não } \\
\text { governamentais de } \\
\text { fomento e promoção do } \\
\text { turismo }\end{array}$ & $\begin{array}{l}\text { Circuito Turístico Caminhos do Rio } \\
\text { Paraíba }\end{array}$ & 4 \\
\hline
\end{tabular}




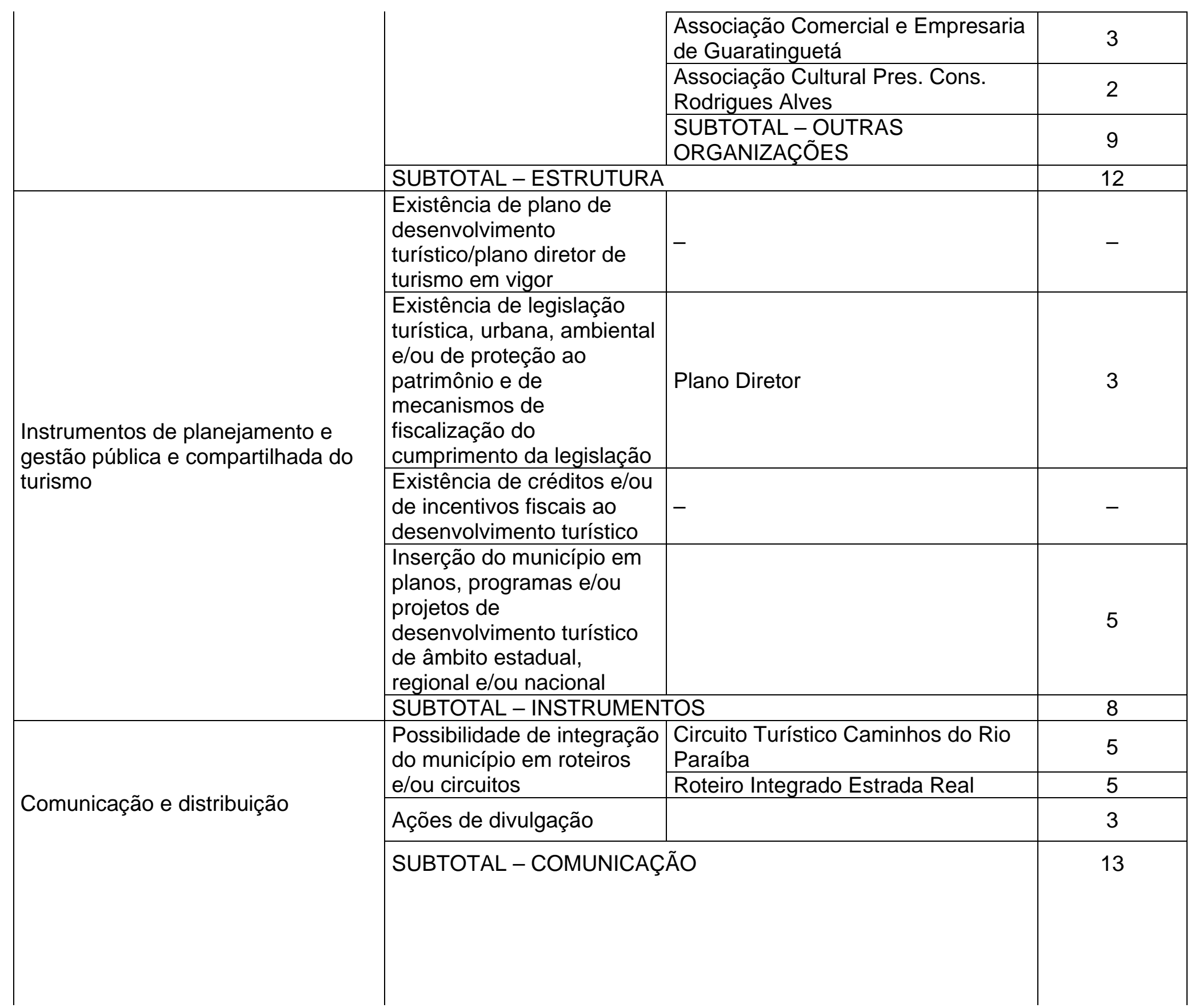




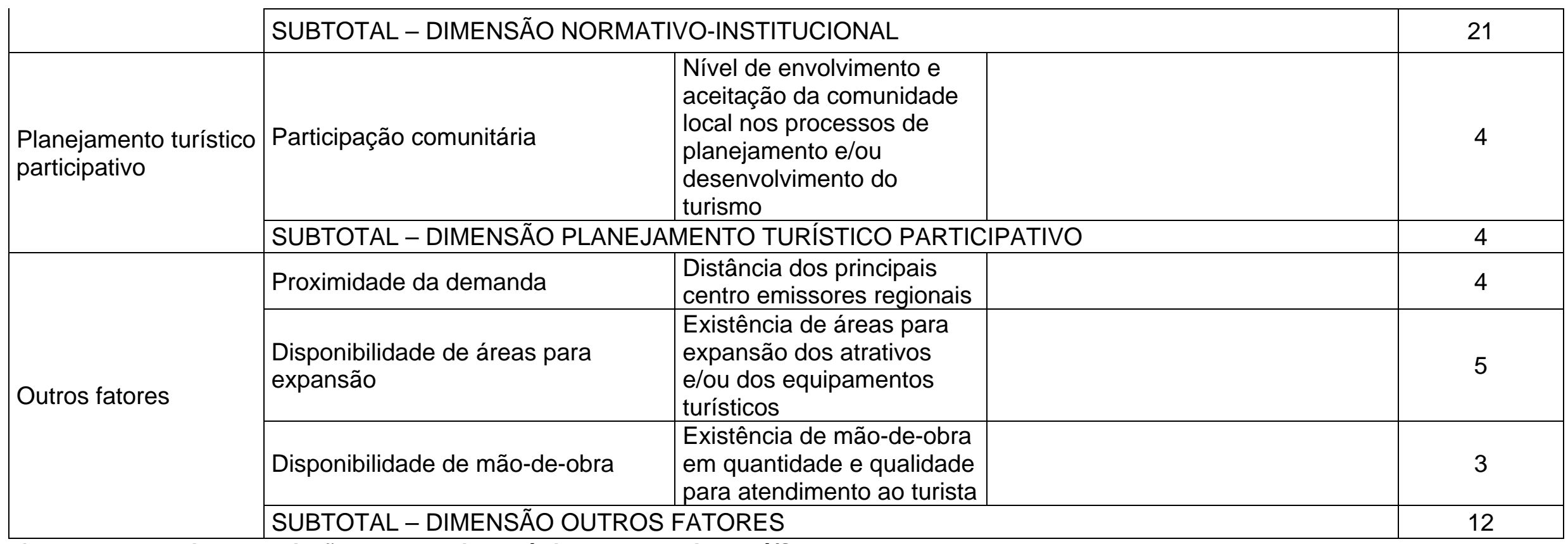

\section{Quadro 21 - Matriz de Avaliação do Potencial Turístico de Guaratinguetá/SP}

Fonte: elaborado pelo autor. 


\begin{tabular}{|c|c|c|c|c|}
\hline Dimensões & Categorias de Análise & Indicadores & Aspectos Analisados & Pontuação \\
\hline \multirow[t]{27}{*}{ Atrativos turísticos } & \multirow{9}{*}{$\begin{array}{l}\text { Naturais (e seus respectivos tipos e } \\
\text { subtipos) }\end{array}$} & \multirow{9}{*}{ Hierarquia dos atrativos } & Pedra da Macela (ou Marcela) & 3 \\
\hline & & & Cachoeira do Pimenta & 2 \\
\hline & & & Cachoeira do Mato Limpo & 2 \\
\hline & & & Cachoeira do Desterro & 2 \\
\hline & & & Cachoeira do Jericó & 2 \\
\hline & & & Águas Virtuosas de Santa Rosa & 1 \\
\hline & & & $\begin{array}{l}\text { Parque Estadual da Serra do Mar - } \\
\text { Núcleo Cunha-Indaiá }\end{array}$ & 3 \\
\hline & & & $\begin{array}{l}\text { Parque Nacional da Serra da } \\
\text { Bocaina }\end{array}$ & 3 \\
\hline & & & SUBTOTAL - NATURAIS & 18 \\
\hline & \multirow{6}{*}{$\begin{array}{l}\text { Histórico-culturais (e seus } \\
\text { respectivos tipos e subtipos) }\end{array}$} & \multirow{6}{*}{ Hierarquia dos atrativos } & $\begin{array}{l}\text { Matriz de Nossa Senhora da } \\
\text { Conceição }\end{array}$ & 2 \\
\hline & & & $\begin{array}{l}\text { Igreja de Nossa Senhora do Rosário } \\
\text { e São Benedito }\end{array}$ & 2 \\
\hline & & & Mercado Municipal & 1 \\
\hline & & & Monumento a Paulo Virgínio & 1 \\
\hline & & & Fazenda Sant'Anna & 2 \\
\hline & & & SUBTOTAL - HISTÓRICO & 8 \\
\hline & \multirow{6}{*}{$\begin{array}{l}\text { Manifestações e usos tradicionais e } \\
\text { populares (e seus respectivos tipos } \\
\text { e subtipos) }\end{array}$} & \multirow{6}{*}{ Hierarquia dos atrativos } & Cerâmica tradicional & 2 \\
\hline & & & Cerâmica Noborigama & 4 \\
\hline & & & Outros tipos de artesanato & 1 \\
\hline & & & Folias de Reis & 1 \\
\hline & & & Congadas e Moçambiques & 1 \\
\hline & & & SUBTOTAL - MANIFESTAÇÕES & 9 \\
\hline & \multirow{3}{*}{$\begin{array}{l}\text { Realizações técnicas e científicas } \\
\text { contemporâneas (e seus respectivos } \\
\text { tipos e subtipos) }\end{array}$} & \multirow{3}{*}{ Hierarquia dos atrativos } & Fungicultura Rio Abaixo & 1 \\
\hline & & & Capril Vale do Jucuí & 1 \\
\hline & & & SUBTOTAL - REALIZAÇÕES & 2 \\
\hline & \multirow{3}{*}{$\begin{array}{l}\text { Acontecimentos programados (e } \\
\text { seus respectivos tipos e subtipos) }\end{array}$} & \multirow[t]{3}{*}{ Hierarquia dos atrativos } & Festival de Verão & 3 \\
\hline & & & Carnaval de Rua & 3 \\
\hline & & & Festa de São José da Boa Vista & 2 \\
\hline
\end{tabular}




\begin{tabular}{|c|c|c|c|c|}
\hline & & & Páscoa & 2 \\
\hline & & & Festa do Pinhão & 3 \\
\hline & & & $\begin{array}{l}\text { Aniversário da Cidade e Cavalaria } \\
\text { da Festa de São Benedito }\end{array}$ & 1 \\
\hline & & & Corpus Christi & 2 \\
\hline & & & Festas Juninas & 2 \\
\hline & & & Festival de Inverno - Acordes na & 3 \\
\hline & & & Festa do Divino & 2 \\
\hline & & & Festa do Peão Valente & 2 \\
\hline & & & Expo-Cunha & 2 \\
\hline & & & Festa da Padroeira & 1 \\
\hline & & & Abertura dos fornos Noborigama & 3 \\
\hline & & & SUBTOTAL - ACONTECIMENTOS & 31 \\
\hline & SUBTOTAL - ATRATIVOS TURÍS & $\mathrm{COS}$ & & 68 \\
\hline Equipamentos e & & & Hotel-fazenda SãoFrancisco & 2 \\
\hline serviços turísticos & & Estrutura dos & Hotel-fazenda Alvorada & 2 \\
\hline & & & SUBTOTAL - ESTRUTURA & 4 \\
\hline & Melos de hospedagem - & & Hotel-fazenda SãoFrancisco & 3 \\
\hline & & Qualladue dos & Hotel-fazenda Alvorada & 3 \\
\hline & & & SUBTOTAL - QUALIDADE & 6 \\
\hline & & SUBTOTAL - HOTELEIR & & 10 \\
\hline & Meios de Hospedagem - & Estrutura dos & Pousada Terra Viva & 1 \\
\hline & estabelecimentos extra-hoteleiros & equipamentos & Pousada Barra do Bié & 1 \\
\hline & & & Pouso Caminho das Artes & 1 \\
\hline & & & Pousada Cheiro da Terra & 1 \\
\hline & & & Pousada Vila Rica & 2 \\
\hline & & & Pousada Entre Amigos & 1 \\
\hline & & & Pousada Recanto Uruguayo & 1 \\
\hline & & & Pousada Recanto das Girafas & 2 \\
\hline & & & Hospedaria Sossego & 1 \\
\hline & & & Pousada dos Girassóis & 1 \\
\hline & & & Pousada Candeias & 2 \\
\hline & & & Pousada do Tropeiro & 1 \\
\hline
\end{tabular}




\begin{tabular}{|c|c|c|c|}
\hline & & Pousada Vista Verde & 2 \\
\hline & & Pousada dos Anjos & 2 \\
\hline & & Pousada Vale das Cachoeiras & 2 \\
\hline & & Pousada Fascinação & 2 \\
\hline & & SUBTOTAL - ESTRUTURA & 23 \\
\hline & \multirow{17}{*}{$\begin{array}{l}\text { Qualidade dos } \\
\text { equipamentos e serviços }\end{array}$} & Pousada Terra Viva & 2 \\
\hline & & Pousada Barra do Bié & 2 \\
\hline & & Pouso Caminho das Artes & 2 \\
\hline & & Pousada Cheiro da Terra & 2 \\
\hline & & Pousada Vila Rica & 3 \\
\hline & & Pousada Entre Amigos & 2 \\
\hline & & Pousada Recanto Uruguayo & 2 \\
\hline & & Pousada Recanto das Girafas & 2 \\
\hline & & Hospedaria Sossego & 2 \\
\hline & & Pousada dos Girassóis & 2 \\
\hline & & Pousada Candeias & 2 \\
\hline & & Pousada do Tropeiro & 2 \\
\hline & & Pousada Vista Verde & 3 \\
\hline & & Pousada dos Anjos & 3 \\
\hline & & Pousada Vale das Cachoeiras & 2 \\
\hline & & Pousada Fascinação & 3 \\
\hline & & SUBTOTAL - QUALIDADE & 36 \\
\hline & \multicolumn{2}{|c|}{ SUBTOTAL - EXTRA-HOTELEIROS } & 59 \\
\hline \multirow[t]{10}{*}{ Alimentação } & \multirow{10}{*}{$\begin{array}{l}\text { Estrutura dos } \\
\text { equipamentos }\end{array}$} & Pousada Barra do Bié & 3 \\
\hline & & Doceria da Cidinha & 2 \\
\hline & & Restaurante Drão & 5 \\
\hline & & Restaurante Vila Rica & 5 \\
\hline & & Restaurante Terra Viva & 4 \\
\hline & & Restaurante dos Girassóis & 3 \\
\hline & & Restaurante Quebra-Cangalha & 4 \\
\hline & & Restaurante Recanto Uruguayo & 4 \\
\hline & & $\begin{array}{l}\text { Restaurante Espaço Country - Café } \\
\text { Bar }\end{array}$ & 2 \\
\hline & & SUBTOTAL - ESTRUTURA & 32 \\
\hline
\end{tabular}




\begin{tabular}{|c|c|c|c|c|}
\hline & & & Pousada Barra do Bié & $\frac{2}{2}$ \\
\hline & & & Restaurante Drão & 4 \\
\hline & & & Restaurante Vila Rica & 4 \\
\hline & & Qualidade dos & Restaurante Terra Viva & 3 \\
\hline & & equipamentos, serviços e & Restaurante dos Girassóis & 3 \\
\hline & & produtos & Restaurante Quebra-Cangalha & 4 \\
\hline & & & Restaurante Recanto Uruguayo & 3 \\
\hline & & & $\begin{array}{l}\text { Restaurante Espaço Country - Café } \\
\text { Bar }\end{array}$ & 3 \\
\hline & & & SUBTOTAL - QUALIDADE & 28 \\
\hline & & SUBTOTAL - ALIMENTAÇ & & 60 \\
\hline & & & Ateliês & 3 \\
\hline & Entretenimentos (e seus respectivos & eguinamentos e servicos & Lojas de artesanato & 3 \\
\hline & tipos e subtipos) & & Pesque Truta Pinheirinho & 2 \\
\hline & & SUBTOTAL - ENTRETENI & IENTOS & 8 \\
\hline & & Estrutura/qualidade dos & Ecotrilhas & 2 \\
\hline & respectivos tipos e subtipos) & equipamentos e serviços & Ecoaventura & 2 \\
\hline & & SUBTOTAL - OUTROS SE & ใVIÇOS & 4 \\
\hline & SUBTOTAL - DIMENSÃO EQUIPAM & ENTOS E SERVIÇOS TURÍ & TICOS & 141 \\
\hline $\begin{array}{l}\text { Infra-estrutura de } \\
\text { apoio turístico }\end{array}$ & $\begin{array}{l}\text { Serviços urbanos (abastecimento de } \\
\text { água, rede de esgotos, limpeza } \\
\text { pública, e energia elétrica) }\end{array}$ & $\begin{array}{l}\text { Estrutura e qualidade dos } \\
\text { serviços }\end{array}$ & & 3 \\
\hline & Acesso rodoviário à localidade & $\begin{array}{l}\text { Condições das vias de } \\
\text { acesso e dos recursos, } \\
\text { serviços e instalações de } \\
\text { apoio a veículos } \\
\text { (sinalização rodoviária e } \\
\text { turística, postos de } \\
\text { abastecimento e serviços } \\
\text { etc.) }\end{array}$ & & 3 \\
\hline
\end{tabular}




\begin{tabular}{|c|c|c|c|}
\hline Circulação Interna & $\begin{array}{l}\text { Condições das vias de } \\
\text { acesso e dos recursos, } \\
\text { serviços e instalações de } \\
\text { apoio a veículos } \\
\text { (sinalização viária e } \\
\text { turística, postos de } \\
\text { abastecimento e serviços } \\
\text { etc.) }\end{array}$ & & 3 \\
\hline Sistema de Transportes & $\begin{array}{l}\text { Estrutura e qualidade dos } \\
\text { servicos }\end{array}$ & & 3 \\
\hline Sistema de Comunicações & $\begin{array}{l}\text { Estrutura e qualidade dos } \\
\text { serviços }\end{array}$ & & 2 \\
\hline Sistema de Segurança & $\begin{array}{l}\text { Estrutura e qualidade dos } \\
\text { serviços }\end{array}$ & & 4 \\
\hline Equipamento médico-hospitalar & $\begin{array}{l}\text { Estrutura e qualidade dos } \\
\text { serviços }\end{array}$ & & 3 \\
\hline \multicolumn{3}{|c|}{ SUBTOTAL - DIMENSÃO INFRA-ESTRUTURA DE APOIO TURÍSTICO } & 21 \\
\hline \multirow{7}{*}{ Estrutura } & $\begin{array}{l}\text { Existência e atuação do } \\
\text { órgão oficial de turismo }\end{array}$ & Coordenadoria de Turismo e Cultura & 5 \\
\hline & $\begin{array}{l}\text { Existência e atuação do } \\
\text { conselho municipal de } \\
\text { turismo }\end{array}$ & - & - \\
\hline & $\begin{array}{l}\text { Existência e gestão do } \\
\text { fundo municipal de turismo }\end{array}$ & - & - \\
\hline & \multirow{3}{*}{$\begin{array}{l}\text { Existência e atuação de } \\
\text { outras organizações não } \\
\text { governamentais de } \\
\text { fomento e promoção do } \\
\text { turismo }\end{array}$} & Cunhatur & 5 \\
\hline & & Cunha Cerâmica & 5 \\
\hline & & $\begin{array}{l}\text { SUBTOTAL - OUTRAS } \\
\text { ORGANIZAÇÕES }\end{array}$ & 10 \\
\hline & \multicolumn{2}{|l|}{ SUBTOTAL - ESTRUTURA } & 15 \\
\hline $\begin{array}{l}\text { Instrumentos de planejamento e } \\
\text { gestão pública e compartilhada do } \\
\text { turismo }\end{array}$ & $\begin{array}{l}\text { Existência de plano de } \\
\text { desenvolvimento } \\
\text { turístico/plano diretor de } \\
\text { turismo em vigor }\end{array}$ & - & - \\
\hline
\end{tabular}

Normativo-

institucional 


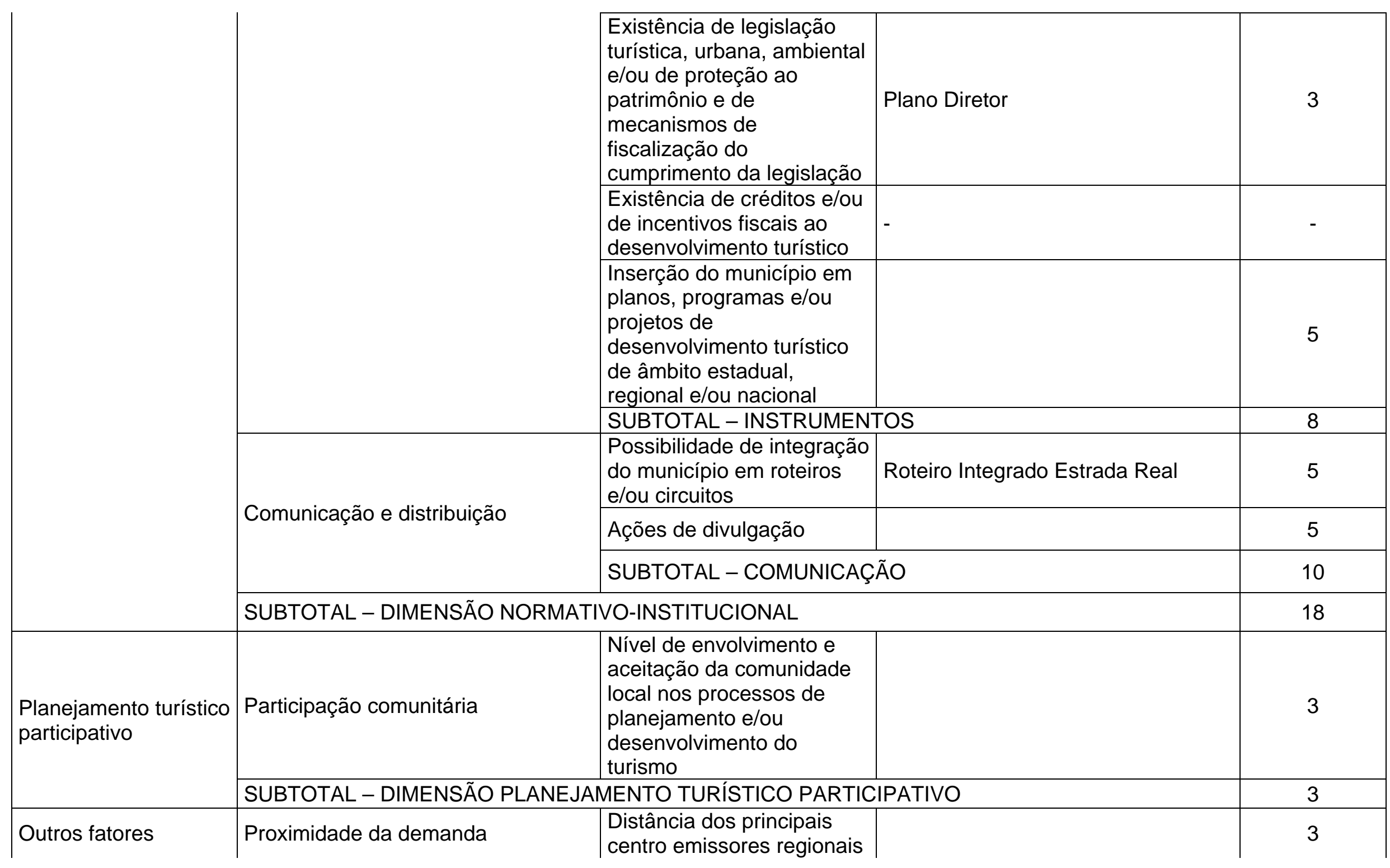




\begin{tabular}{|l|l|c|c|}
\hline $\begin{array}{l}\text { Disponibilidade de áreas para } \\
\text { expansão }\end{array}$ & $\begin{array}{l}\text { Existência de áreas para } \\
\text { expansão dos atrativos } \\
\text { e/ou dos equipamentos } \\
\text { turísticos }\end{array}$ & 5 \\
\hline Disponibilidade de mão-de-obra & $\begin{array}{l}\text { Existência de mão-de-obra } \\
\text { em quantidade e qualidade } \\
\text { para atendimento ao turista }\end{array}$ & 2 \\
\hline SUBTOTAL - DIMENSÃO OUTROS FATORES & 10 \\
\hline
\end{tabular}

Quadro 22 - Matriz de Avaliação do Potencial Turístico de Cunha/SP

Fonte: elaborado pelo autor. 


\subsection{Discussão dos Resultados}

Trigo (2000, p. 243-255), ao apresentar uma lista de problemas que devem ser sanados e mal-entendidos que devem ser desfeitos para que se tenha uma melhor visualização das possibilidades de desenvolvimento do turismo no país e, em decorrência disto, das oportunidades do mercado de trabalho na área, questiona: "o potencial turístico do Brasil é fantástico. É mesmo?" (TRIGO, 2000, p.253).

Ao tentar responder a esta pergunta, o autor relembra que, realmente, nosso território oferece uma enorme variedade de belezas naturais e de manifestações culturais já amplamente descritas e analisadas por vários intelectuais de diversas áreas do conhecimento, da literatura à sociologia; mas, também ressalta que as mazelas nacionais também estão constantemente em pauta nestes mesmos círculos - o que exige cuidado na concordância automática com a afirmação anterior (TRIGO, 2000, p.253).

Em segundo lugar, potencial não significa realização. Imagine, por exemplo, o minério. Uma região com traços de minérios possui um potencial de riquezas no subsolo. Porém esse potencial precisa sofrer uma prospecção para ser avaliado em termos de viabilidade econômica, processado, industrializado e vendido. Do potencial ao lucro existe um longo caminho e muito investimento em capital, tecnologia e trabalho.

O mesmo acontece com o turismo. Uma praia deserta, uma cidade histórica decadente e sem vias de acesso, um litoral poluído, uma área verde inacessível, falta de infra-estrutura ou uma cidade sem folhetos e política de marketing são problemas e não soluções para o turismo (TRIGO, 2000, p.253-254). 
O autor, ao mencionar a apresentação de uma especialista em marketing norteamericana feita em um evento sobre turismo, relembra que as características naturais do Brasil em muito se assemelham às de outros importantes destinos turísticos litorâneos mundiais e, além disso, ainda há a concorrência com outras paisagens únicas disponíveis apenas em outros países da América do Sul; todavia, Trigo (2000, p.254) ainda acredita que o Brasil tenha condições de competitividade no continente e no mundo.

Desde que existam políticas públicas de turismo bem elaboradas (da esfera municipal à esfera federal), desde que o poder público e a iniciativa privada trabalhem juntos; desde que os empresários se associem a outros empresários e os municípios formem regiões de comercialização comum e planejada de seus produtos turísticos; desde que programas de qualidade não sejam peças fajutas de marketing e que os certificados ISO-9000 ajudem a modificar a mentalidade dos prestadores de serviço; desde que preservação ambiental não sucumba à corrupção dos micropoderes locais interessados em seus próprios pequenos lucros e trocas políticas; desde que a formação profissional seja encarada como uma necessidade urgente, continuada e capaz de fazer grandes diferenças no mercado e na sociedade; e desde que antigos preconceitos como estes que estamos listando sejam vencidos pelo conhecimento, pela mente aberta e pelos interesses comuns a toda a sociedade. Entre esses preconceitos menores estão o medo do lucro e o medo do mercado [...] (TRIGO, 2000, p.254).

E assim como outros autores mencionados nesta tese, Pires também apresenta uma certa inquietação com a vulgarização com que é tratado, normalmente, o desenvolvimento do turismo no país, e pergunta: "Que razões estariam determinado o atual interesse de um número crescente de municípios pelo Brasil afora em incorporar o turismo?"; e, a partir desta questão, o autor parte para a elaboração de reflexões que possibilitem sustentar o enfoque central de sua abordagem, qual seja, "a busca por alternativas turísticas nos municípios a partir da ocorrência e da qualidade e da diferenciação dos recursos naturais e culturais neles existentes" (PIRES, 2005, p.176). 
De início o que parece despertar o interesse nos municípios e nos seus cidadãos pelo turismo é, sobretudo, a difusão através dos meios de comunicação de massa, de uma imagem emoldurada e, em muitos casos, plena dos estereótipos típicos do turismo convencional, produzindo um efeito de "canto de sereia" junto à população que não vive e desconhece a realidade turística dos destinos e regiões turísticas propaladas, e cuja ressonância pode originar dois tipos de impulsos: o natural desejo de viajar e ser turista; e a atração pelo negócio do turismo em si, ainda que sob total desconhecimento das múltiplas facetas que regem esta atividade (PIRES, 2005, p.176).

O autor afirma, ainda, que as razões difusas que levam autoridades municipais e outras forças das municipalidades a cortejar o turismo de forma perigosamente entusiasta, ao extremo de vislumbrá-lo como panacéia capaz de tudo resolver, trazendo a prosperidade e eliminando as arraigadas chagas de subdesenvolvimento social e econômico, podem ser abordadas a partir de dois pressupostos:

a limitada capacidade de discernimento destes atores em relação à complexidade e abrangência do cenário contemporâneo do turismo, fazendo com que suas intenções e ações sejam marcadas pelo simplismo inconseqüente ou imediatismo irresponsável;

a adoção consciente do turismo como bandeira desenvolvimentista destinada a servir de cortina de fumaça para a ação de interesses corporativos e políticos incompatíveis com 0 interesse comum da sociedade. No primeiro caso o turismo é geralmente assumido como "bandeira" já a partir das campanhas eleitorais, pela simples necessidade política de se ter uma bandeira e o quanto mais vistosa - como o é o turismo na atualidade -, melhor. Nos casos onde esta atividade ainda não integra a economia local, trata-se de apresentá-la como uma nova promessa de redenção econômica para todos (PIRES, 2005, p.178).

O autor analisa, pois, que nas localidades em que o turismo começa a manifestar-se de forma introdutória, nas quais segmentos da população ainda detém seu patrimônio (seja na zona rural ou na cidade-sede dos municípios), a chegada do turismo coincide com a vinda, de forma quase sempre espontânea, dos primeiros turistas aventureiros, resultando em uma exploração turística rudimentar - situação 
já relatada por outros autores na literatura da área -, que pode ser evitada a partir de

[...] uma avaliação sensata e isenta dos tomadores de decisão, por sua vez respaldada em estudos criteriosos $^{66}$ e na percepção de atores-chave [...]. A partir daí, trata-se de investir na formação de produtos turísticos e na sua promoção junto a um mercado cujo nível de competição será diretamente proporcional ao raio de abrangência geográfica da demanda almejada (PIRES, 2005, p.179).

De acordo com as premissas acima, muitos municípios e suas microrregiões deverão adequar-se a um turismo eminentemente doméstico, o que significa uma limitada movimentação de visitantes e, por conseqüência, uma modesta entrada de receitas e divisas para a economia local - percepção particularmente importante em um momento em que todo destino acredita-se insuperável em termos de atratividade turística.

Efetivamente, de acordo com as análises anteriormente apresentadas, muitas das questões levantadas por Trigo e Pires são facilmente encontradas em várias localidades espalhadas ao longo do vasto território abrangido pelo Roteiro Integrado Estrada Real - e, particularmente, puderam ser observados mais de perto nos municípios escolhidos para aplicação do estudo ora proposto: Guaratinguetá e Cunha, ambos localizados no Vale do Paraíba, Estado de São Paulo.

Assim, não é difícil, pois, de se indagar até que ponto tais processos não vêm ocorrendo nos municípios paulistas localizados no eixo central (e mesmo na área de entorno) do Roteiro Integrado Estrada Real - e, consequentemente, de se indagar,

${ }^{66}$ Grifo nosso. 
também, a respeito das factíveis condições de engajamento de tais municípios neste processo considerando-se suas condições mercadológicas atuais.

E, ainda, no tocante à questão da competitividade, realidade que se apresenta de forma irreversível no turismo como forma de atrair novos turistas ou de obter a "fidelização" daqueles já conquistados, o autor destaca três condicionantes como geradores potenciais de competitividade no turismo: a formatação de roteiros e pacotes acessíveis $^{67}$ no âmbito da oferta turística (seja para torná-los acessíveis a segmentos mais amplos de consumidores, seja para continuar a garantir a preferência dos segmentos habitualmente consumidores do turismo, porém no limite de seu orçamento e de suas exigências); a qualidade do produto como um todo, cuja essência é o atrativo turístico, passando a ter um papel decisivo no momento da opção de viagem do turista, no tempo de permanência nos destinos e na longevidade no consumo do referido produto, e a possibilidade de apor um diferencial ao produto turístico quando da sua oferta para um mercado com amplos segmentos ávidos por realizar novas experiências turísticas, que proporcionem a ampliação dos horizontes pessoais nos níveis emotivo, social e educativo (PIRES, 2005, p.182).

É, portanto, no sentido de auxiliar o processo de análise das condições que podem reverter-se nos condicionantes geradores potenciais de competitividade no turismo apontados por Pires, que o instrumento ora elaborado propõe a consideração de uma ampla gama de dimensões, categorias de análise, indicadores e critérios que, acredita-se, dêem conta dos principais aspectos a serem analisados a fim de se atingir os objetivos arrolados no início desta tese - evidentemente, esta lista poderia 
ser ainda muito maior (inesgotável, quiçá); todavia, havia que se pensar em uma proposta exeqüível, dadas as condições existentes para a realização de um trabalho desta natureza.

Retomando a abordagem do subcapítulo anterior, obteve-se, por meio da somatória dos resultados por indicadores, categorias de análises e dimensões, o total de pontos alcançado por cada município.

A partir destes totais, que pouco podem ajudar na visualização do panorama encontrado, foram extraídas as médias aritméticas simples destes indicadores, categorias de análises e dimensões, dividindo-se os resultados obtidos das somatórias pelo número de aspectos analisados; e, quando os mesmos aspectos foram analisados duas vezes sob ângulos diferentes, adotou-se o procedimento de repetir a extração das médias, considerando a segunda avaliação e, posteriormente, extraiu-se uma média da categoria como um todo.

Para facilitar os cálculos, foi adotado o mesmo critério de arredondamento estabelecido pela metodologia de inventário da oferta turística da EMBRATUR (Empresa Brasileira de Turismo, 1984, p.113): nos casos em que o resultado da divisão chegar a, no máximo, 1,50 (considerando a segunda casa decimal), por exemplo, o resultado será arredondado para 1; e nos casos em que o resultado da divisão for igual ou superior 1,51 (considerando a segunda casa decimal), por exemplo, o resultado será arredondado para 2.

O resultado obtido pode ser visualizado no quadro seguinte:

${ }^{67}$ Grifo do autor. 


\begin{tabular}{|c|c|c|c|c|c|c|}
\hline \multirow[t]{3}{*}{ Dimensões } & \multirow[t]{3}{*}{ Categorias de Análise } & \multirow[t]{3}{*}{ Indicadores } & \multicolumn{4}{|c|}{ Resultados (Por Município) } \\
\hline & & & \multicolumn{2}{|c|}{ Guaratinguetá } & \multicolumn{2}{|c|}{ Cunha } \\
\hline & & & $\begin{array}{l}\text { Total de } \\
\text { Pontos }\end{array}$ & Médias & $\begin{array}{l}\text { Total de } \\
\text { Pontos }\end{array}$ & Médias \\
\hline \multirow{5}{*}{$\begin{array}{l}\text { ATRATIVOS } \\
\text { TURÍSTICOS }\end{array}$} & Naturais & \multirow{5}{*}{$\begin{array}{l}\text { Hierarquia dos } \\
\text { atrativos }\end{array}$} & 16 & 2 & 18 & 2 \\
\hline & Histórico-culturais & & 36 & 1 & 8 & 2 \\
\hline & $\begin{array}{l}\text { Manifestações e usos } \\
\text { tradicionais e populares }\end{array}$ & & 2 & 2 & 9 & 2 \\
\hline & $\begin{array}{l}\text { Realizações técnicas e } \\
\text { científicas } \\
\text { contemporâneas }\end{array}$ & & 3 & 3 & 2 & 1 \\
\hline & $\begin{array}{l}\text { Acontecimentos } \\
\text { programados }\end{array}$ & & 46 & 2 & 31 & 2 \\
\hline \multicolumn{3}{|c|}{ SUBTOTAL - DIMENSÃO ATRATIVOS TURÍSTICOS } & 103 & 2 & 68 & 2 \\
\hline \multirow{11}{*}{$\begin{array}{l}\text { EQUIPAMENTOS } \\
\text { E SERVIÇOS } \\
\text { TURÍSTICOS }\end{array}$} & \multirow{2}{*}{$\begin{array}{l}\text { Meios de hospedagem - } \\
\text { estabelecimentos } \\
\text { hoteleiros }\end{array}$} & $\begin{array}{l}\text { Estrutura dos } \\
\text { equipamentos }\end{array}$ & 20 & 5 & 4 & 2 \\
\hline & & $\begin{array}{l}\text { Qualidade dos } \\
\text { equipamentos e } \\
\text { serviços }\end{array}$ & 14 & 3 & 6 & 3 \\
\hline & \multicolumn{2}{|c|}{ SUBTOTAL - CATEGORIA HOTELEIROS } & 34 & 4 & 10 & 2 \\
\hline & $\begin{array}{l}\text { Meios de hospedagem - } \\
\text { estabelecimentos extra- } \\
\text { hoteleiros }\end{array}$ & $\begin{array}{l}\text { Estrutura dos } \\
\text { equipamentos }\end{array}$ & 18 & 4 & 23 & 1 \\
\hline & & $\begin{array}{l}\text { Qualidade dos } \\
\text { equipamentos e } \\
\text { serviços }\end{array}$ & 18 & 4 & 36 & 2 \\
\hline & \multicolumn{2}{|c|}{$\begin{array}{l}\text { SUBTOTAL - CATEGORIA EXTRA- } \\
\text { HOTELEIROS }\end{array}$} & 36 & 4 & 59 & 2 \\
\hline & Alimentação & $\begin{array}{l}\text { Estrutura dos } \\
\text { equipamentos }\end{array}$ & 97 & 4 & 32 & 4 \\
\hline & & $\begin{array}{l}\text { Qualidade dos } \\
\text { equipamentos, } \\
\text { serviços e } \\
\text { produtos }\end{array}$ & 77 & 3 & 28 & 3 \\
\hline & \multicolumn{2}{|c|}{ SUBTOTAL - CATEGORIA ALIMENTAÇÃO } & 174 & 4 & 60 & 3 \\
\hline & $\begin{array}{l}\text { SUBTOTAL - } \\
\text { ENTRETENIMENTOS }\end{array}$ & $\begin{array}{l}\text { Estrutura/qualidad } \\
\text { e dos } \\
\text { equipamentos e } \\
\text { serviços }\end{array}$ & 4 & 2 & 8 & 3 \\
\hline & $\begin{array}{l}\text { SUBTOTAL - OUTROS } \\
\text { SERVIÇOS TURÍSTICOS }\end{array}$ & $\begin{array}{l}\text { Estrutura/qualidad } \\
\text { e dos } \\
\text { equipamentos e } \\
\text { serviços } \\
\end{array}$ & 3 & 3 & 4 & 2 \\
\hline \multicolumn{3}{|c|}{$\begin{array}{l}\text { SUBTOTAL - DIMENSÃO EQUIPAMENTOS E SERVIÇOS } \\
\text { TURÍSTICOS }\end{array}$} & 251 & 4 & 141 & 2 \\
\hline \multicolumn{3}{|c|}{$\begin{array}{l}\text { SUBTOTAL - DIMENSÃO INFRA-ESTRUTURA DE APOIO } \\
\text { TURÍSTICO }\end{array}$} & 34 & 5 & 21 & 3 \\
\hline \multirow{3}{*}{$\begin{array}{l}\text { NORMATIVO- } \\
\text { INSTITUCIONAL }\end{array}$} & \multicolumn{2}{|l|}{\begin{tabular}{|l|} 
Estrutura \\
\end{tabular}} & 12 & 2 & 15 & 3 \\
\hline & \multicolumn{2}{|c|}{$\begin{array}{l}\text { Instrumentos de planejamento e gestão pública } \\
\text { e compartilhada do turismo }\end{array}$} & 8 & 2 & 8 & 2 \\
\hline & \multicolumn{2}{|c|}{ Comunicação e distribuição } & 13 & 4 & 10 & 5 \\
\hline \multicolumn{3}{|c|}{ SUBTOTAL - DIMENSÃO NORMATIVO-INSTITUCIONAL } & 21 & 2 & 18 & 3 \\
\hline \multicolumn{3}{|c|}{$\begin{array}{l}\text { SUBTOTAL - DIMENSÃO PLANEJAMENTO TURÍSTICO } \\
\text { PARTICIPATIVO }\end{array}$} & 4 & 4 & 3 & 3 \\
\hline \multicolumn{3}{|c|}{ SUBTOTAL - DIMENSÃO OUTROS FATORES } & 12 & 4 & 10 & 3 \\
\hline \multicolumn{3}{|l|}{ TOTAL GERAL } & & 3,5 & & 2,6 \\
\hline
\end{tabular}

Quadro 23 - Análise comparativa do potencial turístico de Guaratinguetá e Cunha Fonte: elaborado pelo autor. 
O quadro acima permite que se façam as seguintes observações (embora seja possível comparar os resultados por cada indicador, categoria de análise e dimensão, a análise concentra-se nos agrupamentos expressos nos subtotais):

- analisando-se os resultados dos subtotais de cada dimensão, observa-se que, embora a pontuação obtida pelos atrativos de Guaratinguetá sejam consideravelmente superiores aos de Cunha, ambos os municípios obtiveram iguais médias, o que se explica pelos baixos níveis de atratividade destes atrativos do ponto de vista das suas hierarquias;

- Guaratinguetá apresenta elevada vantagem em termos de oferta de equipamentos hoteleiros, ocorrendo o mesmo com Cunha quando se consideram os equipamentos extra-hoteleiros, o que pode ser explicado pela característica territorial do turismo nos municípios (urbana em Guaratinguetá e rural/ecológico em Cunha); a mesma vantagem de Guaratinguetá, pelo mesmo motivo exposto aqui, apresenta-se na categoria "alimentação";

- aliás, Guaratinguetá obteve elevada pontuação na dimensão "equipamentos e serviços turísticos", refletindo-se na média desta dimensão; também na dimensão "infra-estrutura de apoio turístico" a média de Cunha é inferior;

- em relação à dimensão normativo-institucional, embora a diferença (tanto da pontuação como das médias) seja pequena entre os municípios, Cunha apresenta leva vantagem sobre Guaratinguetá por conta do envolvimento de organizações não governamentais ligadas ao fomento do turismo;

- a média do total geral foi deixada propositadamente sem arredondamento, considerando-se uma casa decimal, a fim de expressar claramente a diferença dos resultados obtidos pelos municípios. 


\title{
CONSIDERAÇÕES FINAIS
}

\begin{abstract}
Nos vários seminários e eventos sobre turismo que acontecem pelo país é muito comum ouvir prefeitos de pequenas cidades, vereadores, comerciantes e o público em geral comentarem que o Brasil é um país maravilhoso, em que o céu é mais azul, o mar é mais lindo e as matas são mais verdes, sem contar que suas cidades oferecem preciosidades ainda desconhecidas e sonham com o dia em que o Fantástico fizer uma reportagem de cinco minutos sobre "aquela" cachoeira ou "aquele" prédio histórico onde o tio de D. Pedro II tomou café com rapadura. [...] (TRIGO, 2000, p.253).
\end{abstract}

A epígrafe acima satiriza de forma muito adequada a problemática que motivou o surgimento deste estudo: a crença no incomparável potencial turístico de determinadas localidades, alicerçada única e exclusivamente no empirismo, no gosto pessoal - por vezes, duvidoso - de boa parte dos gestores públicos (mas também da iniciativa privada) em relação aos destinos turísticos.

Felizmente, tal preocupação já encontra eco nas opiniões de vários outros pesquisadores. Gunn (1980, p.262), por exemplo, ao defender sua abordagem sobre a avaliação do potencial de desenvolvimento turístico, afirma que existe uma crença popular segundo a qual todas as localidades têm igual potencial para 0 desenvolvimento turístico se intensamente promovidas - ainda que a promoção seja um fator fundamental do turismo contemporâneo, outros elementos são igualmente importantes - o que faz com que certas localidades tenham características que ofereçam maior suporte em termos de potencial turístico do que outras, o que esta tese vem demonstrar ao analisar de que forma tal fenômeno se apresenta nos municípios de Guaratinguetá e Cunha, localizados no eixo principal do Roteiro Integrado Estrada Real. 
No que diz respeito à Estrada Real, Toledo (2004, p.76), ao falar em "velhos caminhos, novos tempos", comenta que o tempo de revitalização e de reutilização é marcado pelo surgimento do caminho do turismo a partir de 1950 (TOLEDO, 2004, p.79): o antigo Caminho Velho encontra-se atualmente modificado em relação ao seu trajeto original; o traçado atual da rodovia, aberta em 1953, procurou se adequar ao trânsito de automóveis, tendo parte de seu piso construído sobre o antigo Caminho do Ouro e recebendo o nome de "Paulo Virgínio", no trecho que liga Guaratinguetá às divisas de Paraty.

Ainda segundo o autor (TOLEDO, 2004, p.79), a estrada federal Rio-Santos, inaugurada em 1974, colocou Paraty dentro do eixo rodoviário litorâneo Rio de Janeiro-São Paulo, o que contribuiu para que se firmasse o turismo como atividade econômica predominante no litoral sul fluminense ${ }^{68}$ e para que os paratienses retomassem uma relação mais cotidiana e intenda com as cidades de Cunha, Guaratinguetá, Taubaté e Ubatuba, ao mesmo tempo em que conduziu os habitantes do vale do Paraíba ao reencontro do litoral fluminense - o que vem possibilitando o incremento do turismo cultural e a aquisição de imóveis urbanos e terras no litoral fluminense pelas classes média e alta paulista. "Mais do que isto, vem diluindo a percepção de fronteira política-administrativa regional, favorecendo a implementação do projeto da Estrada Real em toda área" (TOLEDO, 2004, p.79).

Hoje, os velhos caminhos continuam servindo como ponto de passagem do litoral para o interior e vice-versa, e, como rota de comunicação e de trânsito de pessoas e do comércio intra-regional. Preenche uma nova função histórica, a de criar condições para o desenvolvimento regional sustentável. Pois permite integrar ações fundamentais para a humanidade nos dias de hoje, como a preservação ambiental e do patrimônio cultural construídos ao longo de três séculos. Permite realizar trabalho no sentido

${ }^{68}$ Assim como no litoral norte paulista. 
de resgatar a memória coletiva, afirmar as identidades locais e manter as antigas e significativas tradições de seu povo. Passam assim a servir como instrumento para preparar a região no avanço da sociedade na passagem para o período denominado de pós-moderno, e, unir os esforços da sociedade civil organizada ao lado de instituições oficiais [...], para o desenvolvimento de uma grande rota turística, o projeto Estrada Real, integrando antigas áreas de mineração, o Vale, a serra e o mar" (TOLEDO, 2004, p.80).

Quanto ao Roteiro Integrado Estrada Real, há que se reconhecer que muito se avançou neste projeto, sobretudo por iniciativa do Instituto Estrada Real, que realizou um enorme esforço de articulação e mobilização de patrocinadores, apoiadores, governos (dos três níveis) e outras instituições, garantindo os resultados até então obtidos.

Todavia, ainda há muito a fazer, tanto em termos de esforços de comercialização do Roteiro como em níveis mais básicos, de planejamento e organização das localidades por ele abrangidas - para o que este trabalho espera contribuir, ao possibilitar uma avaliação do potencial turístico das localidades nele envolvidas.

Neste sentido, e retomando o tema que ronda o problema desta pesquisa, deve-se perguntar: o que se pode entender, afinal, por potencial turístico?

Diante do até aqui exposto, propõe-se a seguinte definição: potencial turístico pode ser entendido como a existência de condições objetivas favoráveis da oferta turística, dos aspectos normativo-institucionais e de outros fatores complementares capazes de viabilizar, por meio do adequado planejamento, 
uma exploração turística sustentável destinada a satisfazer uma demanda atual ou latente ${ }^{69}$.

E, ainda, relacionando-se a definição supra com os resultados obtidos por meio da matriz de avaliação apresentada no subcapítulo 2.2, pode-se afirmar que, com base na análise das condições objetivas favoráveis da oferta turística, dos aspectos normativo-institucionais e de outros fatores complementares capazes de viabilizar, por meio do adequado planejamento, uma exploração turística sustentável destinada a satisfazer uma demanda atual ou latente, o município de Guaratinguetá apresenta maior potencial turístico que o de Cunha, comparativamente.

A matriz de avaliação apresentada anteriormente permite observar, de forma comparativa em relação a outras localidades, em que dimensões encontram-se as forças e as fraquezas das áreas estudadas - o que pode orientar investimentos, redirecionamentos e ações a fim de potencializar estas forças ou de minimizar as fraquezas. Assim:

- se a dimensão "atrativos turísticos" (que pode, ainda, ser vista de forma particularizada segundo suas cinco categorias de análise) apresentar resultados mais elevados que as demais dimensões, pode-se concluir que a potencialidade turística da localidade estará baseada na força que estes elementos têm de

${ }^{69}$ A respeito do conceito de demanda latente, Kotler (1998, p.34) diz que "muitos consumidores podem sentir forte necessidade que não pode ser satisfeita por qualquer produto existente. [...] A tarefa de marketing é mensurar o tamanho do mercado potencial e desenvolver bens e serviços eficazes que atenderiam à demanda". 
estimular a visitação, o que reforçaria a necessidade de adequação da oferta técnica a esta realidade e de fortalecer o envolvimento da superestrutura e da comunidade (se assim for de seu desejo) neste processo de desenvolvimento;

- por outro lado, se a dimensão "equipamentos e serviços turísticos" apresentar maior resultado, será possível perceber que a força da localidade estará, talvez, na oferta de equipamentos de hospedagem e/ou de outros serviços, em conjunto ou isoladamente, o que poderia significar a existência de uma oferta ociosa ou subutilizada, ou ainda, utilizada por um público diferente daquele que visita a localidade em busca de seus atrativos (turistas de negócios, por exemplo) nestes casos, uma tentativa de integração destas ofertas faz-se necessária, a fim de permitir um aproveitamento e uma exploração mais racional e (possivelmente) rentável de ambas;

- já a obtenção de pontuações preponderantemente elevadas nas dimensões "infra-estrutura de apoio turístico", "normativo-institucional", "planejamento turístico participativo" e "outros fatores" podem indicar que, embora a localidade ainda não tenha uma oferta de atrativos e/ou de equipamentos e serviços turísticos forte o bastante para gerar visitação, ela possui, de outra parte, um conjunto de condições favoráveis importantes que muitas vezes são desconsiderados em localidades com forte poder de atração já consolidado, como as questões da infra-estrutura básica, da gestão pública do turismo, da participação comunitária e outras.

Neste sentido, tal tipo de avaliação parece ser bastante útil aos interessados no desenvolvimento turístico das localidades, como reforça Olivares (2006), que analisou e aplicou uma avaliação hierárquica e ponderada dos recursos turísticos 
das comarcas da Comunidade Valenciana (Espanha) ${ }^{70}$ e concluiu que o grau de potencialidade daqueles recursos é alto, mas o grau de exploração, tanto em termos de uso como de renda, é baixo - segundo o autor, aquela região oferece recursos turísticos muito mais potenciais que reais, devido ao fato de a maioria dos recursos se produzir de forma espontânea e passiva não integrada ao que o autor denomina produto turístico (OLIVARES, 2006, p.155) - o que, aparentemente, também manifesta-se em Guaratinguetá e Cunha.

Seja como for, a proposta supramencionada não pretendeu esgotar a possibilidade de elementos que poderiam vir a compor uma matriz desta natureza - como já mencionado anteriormente - assim, outros aspectos podem ainda ser considerados em uma avaliação qualitativa mais global, como, por exemplo:

- a compatibilidade com atividades não turísticas que, segundo Pearce (1991, p.113) também é uma consideração importante;

- a segregação do espaço turístico (Silva, 2004, p.38);

- outros impactos do turismo.

Também não se pretendeu aqui, por meio da matriz proposta, estabelecer um ranking de destinações turísticas a partir de índices de potencialidade turística, como fizeram Leno Cerro (1992, p.81-82), ao determinar, por meio de métodos aritméticos, Índices de Potencial Turístico (IPT) dos municípios localizados às margens do Canal de Castilha (Espanha), resultando na seguinte classificação:

${ }^{70}$ Deve-se observar que o autor não analisou os demais componentes da oferta turística da área em 
- municípios com alto potencial turístico (IPT entre 75 e 100 pontos);

- municípios com potencial turístico médio-alto (IPT entre 50 e 75 pontos);

- municípios com potencial turístico médio (IPT entre 40 e 50 pontos);

- municípios com potencial turístico médio-baixo (IPT entre 30 e 40 pontos);

- municípios com potencial turístico baixo (IPT inferior a 30 pontos);

ou Ferrario (1980 apud LENO CERRO, 1993, p.134), que, a partir de uma equação do valor turístico local (VTL) que considera o índice de potencialidade turística de recursos e um fator de ponderação exponencial, estabeleceu a seguinte classificação do potencial turístico local:

- localidade de primeiro nível: alto potencial turístico (VTL superior a 1.000 pontos);

- localidade de segundo nível: potencial turístico médio-alto (VTL entre 500 e 1.000 pontos);

- localidade de terceiro nível: potencial turístico médio-baixo (VTL entre 200 e 500 pontos);

- localidade de quarto nível: potencial turístico baixo ou nulo (VTL inferior a 200 pontos).

O método ora proposto deve possibilitar, pois, a comparação entre os resultados, em termos de potencial turístico, das localidades analisadas, dada a pequena amostra utilizada neste estudo - uma evolução deste estudo, com a utilização de uma amostra maior de municípios e o uso de métodos aritméticos mais robustos, pode permitir a aplicação de rankings como os propostos por Leno Cerro e Ferrario, supramencionados. 
O estudo ora proposto parte, como se pôde observar, da perspectiva da oferta - não que a demanda não deva ser considerada, apenas não foi este o enfoque escolhido para esta tese -, aliás, o estudo da demanda pode contribuir em muito para o aperfeiçoamento deste método ${ }^{71}$. De qualquer forma, acredita-se que as hipóteses formuladas no início deste trabalho e retomadas abaixo foram parcialmente confirmadas:

- a expressão "potencial turístico" é utilizada de maneira vaga, imprecisa e, por vezes, incorreta, possivelmente devido a uma inadequada compreensão de seu significado - hipótese confirmada;

- uma vez adequadamente definida a expressão, talvez seja possível, por meio de um instrumento específico, avaliar em que consiste o potencial para o desenvolvimento do turismo receptivo de lazer de determinados destinos, tanto do ponto de vista qualitativo (condições para que se possa falar, efetivamente, na existência deste potencial) como quantitativo (nível ou grau de "potencialidade") - hipótese parcialmente confirmada, pelo fato do método sugerido não ter chegado a estabelecer níveis ou graus de potencialidade.

Para Pearce (1991, p.101), é difícil que algum país tenha os recursos para desenvolver todas suas possibilidades turísticas simultaneamente, razão pela qual se deve definir áreas prioritárias, sendo essencial o cuidado na seleção e no desenvolvimento destas áreas, dado o número de fatores que podem influir sobre o desenvolvimento turístico e a natureza composta da chamada "indústria turística". 
Além disso, uma vez desenvolvido, o produto turístico torna-se fixo no espaço e não pode ser transferido facilmente.

Neste sentido, o autor comenta que o interesse e a ênfase do planejamento espacial variam em diferentes níveis e destaca que, ao contrário do planejamento ao nível individual (cidade ou centro turístico), em que se dará maior atenção ao desenho físico e à estrutura existente, no planejamento em nível nacional ou regional dar-se-á particular consideração à seleção e distribuição das áreas que serão desenvolvidas.

"Deverão ser levados em conta não apenas o potencial turístico, mas também os objetivos socioeconômicos, sociais e ambientais do desenvolvimento, assim como as relações com outros setores da economia" (PEARCE, 1991, p.101). Tal afirmação reflete o fato de que o método ora proposto deve ser visto não com um fim em si mesmo, mas sim como mais um instrumento para o planejamento turístico de localidades receptoras.

Por fim, não se pretende aqui fechar questão quanto à afirmação de um único método de avaliação do potencial turístico de localidades receptoras, mas sim abrir portas para a (necessária) continuidade de estudos nesta linha, ainda escassos no Brasil.

Talvez, para fins de aprofundamento desta linha de análise, fosse possível, em um período maior de tempo, aplicar a matriz ora proposta a outros (quiçá, a todos os) municípios da Estrada Real, utilizando-se outros procedimentos matemáticos e

\footnotetext{
${ }^{71}$ A este respeito, ver as possibilidades de cruzamento entre oferta e demanda em Beni $(2000$, p.438) e Boullón (2002, p.89-92).
} 
estatísticos mais robustos, para se verificar a existência de diferentes níveis de potencialidade e - mais ainda - repetir estes estudos periodicamente, para se avaliar em que medida as ações que estão sendo encaminhadas estão possibilitando uma mudança nestes níveis de potencialidade.

Certamente, existe ainda uma enorme frente de trabalho na área de planejamento turístico, tanto no âmbito do conhecimento acadêmico como da aplicação prática e empresarial que, espera-se, seja ainda encarada por aqueles que desejam contribuir para o amadurecimento da pesquisa científica em turismo no Brasil. 


\section{REFERÊNCIAS BIBLIOGRÁFICAS ${ }^{72}$}

ACERENZA, Miguel Ángel. Administración del turismo; planificación y dirección. México: Trillas, 1998. 243p. v.2. (Trillas Turismo)

BARRETO, Margarita. Planejamento e organização do turismo. Campinas: Papirus, 1991. 108p. (Coleção Turismo)

BAUD-BOVY, Manuel; LAWSON, Fred. Tourism and recreation development. London: Architectural Press, 1977. 210p.

Tourism \& recreation; handbook of planning and design. 2.ed. Oxford: Architectural Press, 2002. 287p.

BENI, Mário Carlos. Análise estrutural do turismo. 3.ed. rev. e ampl. São Paulo: Ed. SENAC São Paulo, 2000. 517p.

BISSOLI, Maria Angela Marques Ambrizi. Planejamento turístico municipal com suporte em sistemas de informação. São Paulo: Futura, 2000. 170p.

BOULLÓN, Roberto C. Las actividades turísticas y recreacionales; el hombre como protagonista. 3.ed. México: Trillas, abr. 1998. 199p. (Trillas Turismo)

Los municípios turísticos. México: Trillas, 1995. 110p. (Trillas Turismo)

Planejamento do espaço turístico. Tradução por Josely Vianna Baptista. Bauru: EDUSC, 2002. 278p. (Coleção Turis) Tradução de: Planificación del Espacio Turístico.

BRASIL. Ministério do Turismo. Plano nacional do turismo; diretrizes, metas e programas 2003-2007. Brasília, 2003. 48p. - Disponível em: <http://www.turismo gov br/upload/Pilano Nacional do Turismo.pdf set. 2003 .

. Programa de regionalização do turismo; roteiros do Brasil; diretrizes políticas. Brasília, 2004. 31p.

Programa de regionalização do turismo; roteiros do Brasil; roteirização turística; módulo operacional 7. Brasília, 2005a. 43p.

Projeto de formação de rede de cooperação técnica para a roteirização. Brasília, 2005b. 19p.

${ }^{72}$ De acordo com a

ASSOCIAÇÃO BRASILEIRA DE NORMAS TÉCNICAS. NBR 6023: informação e documentação: referências: elaboração. Rio de Janeiro, 2002. 
BUARQUE, Sérgio C.. Construindo o desenvolvimento local sustentável; metodologia de planejamento. Rio de Janeiro: Garamond, 2002. 177p. (Coleção Terra Mater)

CÁRDENAS TABARES, Fabio. Proyectos turísticos; localización e inversión. México: Trillas, 1994. 75p. (Trillas Turismo)

CASAL, Francisco Manuel Zamorano. Turismo alternativo; servicios turísticos diferenciados. México: Trillas, 2002. 336p. (Trillas Turismo)

COOPER, Chris et al. Turismo; princípios e prática. 2.ed. Tradução por Roberto Cataldo Costa. Porto Alegre: Bookman, 2001. 559p. Tradução de: Tourism; principles and practice.

DENCKER, Ada de Freitas Maneti. Métodos e técnicas de pesquisa em turismo. São Paulo: Futura, 1998. 286p.

EMPRESA BRASILEIRA DE TURISMO. Metodologia do inventário da oferta turística. Rio de Janeiro, maio 1984. 168p.

FAGLIARI, Gabriela Scuta; ALMEIDA, Madalena Gonçalves. Análise de atratividade e hierarquização de atrativos: sistematização de métodos e proposta para atrativos culturais. Trabalho de Conclusão de Curso (Pósgraduação Lato Sensu) - Faculdade Senac de Turismo e Hotelaria de São Paulo, 2004. 217p.

FUNARO, Vânia M. B. de Oliveira et al. Diretrizes para apresentação de dissertações e teses da USP: documento eletrônico e impresso. São Paulo: Universidade de São Paulo, 2004. 110p. (Caderno de Estudos; 9)

FÉLIX, Cézar. Entrevista. Roteiros da Estrada Real, Belo Horizonte, ano 2, n.4, p. 8-11, maio 2005.

FERREIRA, Maria Nazareth (org.). A tradição e seu significado para o turismo cultural: o Vale do Paraíba. São Paulo: CELACC, 1999. 233P.

GUIA DE ECOTURISMO ESTRADA REAL - BRASIL. São Paulo: Empresa das Artes, 2005. 203p.

GUIA QUATRO RODAS BRASIL 2000. São Paulo: Abril, 2000. 466p.

GUNN, Clare A. An approach to regional assessment of tourism development potential. In: HAWKINS, Donald E.; SHAFER, Elwood L.; ROVELSTAD, James M.. Tourism planning and development issues. Washington: George Washington University, 1980. p. 261-320. 357p.

Tourism planning. 2.nd. rev. and exp. New York: Taylor \& Francis, 1988. 
HAMMES, Valéria Sucena. Contribuições para o planejamento agroturístico na Área de Proteção Ambiental de Sousas e Joaquim Egídio. Tese (Doutorado) Faculdade de Engenharia Agrícola, Universidade Estadual de Campinas, 1998. $184 p$.

IGNARRA, Luiz Renato. Planejamento turístico é essencial. O Estado de São Paulo, São Paulo, 12 out. 1999. Caderno Viagem, p. 2.

. Planejamento turístico municipal; um modelo brasileiro. São Paulo: CTI . Técnicas, s/d. 83p.

INSKEEP, Edward. Tourism planning; an integrated and sustainable development approach. New York: 1991, John Wiley \& Sons. 508p.

INSTITUTO BRASILEIRO DE TURISMO. Roteiro de informações turísticas RINTUR. Brasília, [1996?]. 23p.

INSTITUTO ESTRADA REAL. Catálogo de serviços; Caminho Velho de Paraty a Ouro Preto; Estrada Real; Brasil. [Belo Horizonte]: 2006. Não paginado.

. Estamos no caminho certo. Belo Horizonte: [2005?]. Folheto.

KOTLER, Philip. Administração de marketing: análise, planejamento, implementação e controle. Tradução por Ailton Bomfim Brandão. 5.ed. São Paulo: Atlas, 1998.

LEA, John. Tourism and development in the third world. New York: Routledge, 1991. 88p. (Routledge Introductions to Development)

LEMOS, Leandro de. Turismo: que negócio é esse? Uma análise da economia do turismo. 3.ed. rev e ampl. Campinas: Papirus, 2001. 143p. (Coleção Turismo)

LENO CERRO, Francisco. La evaluación del potencial turístico en un proceso de planificación: el Canal de Castilla. Estudios Turísticos, Madrid, n.116, p. 49-85, 1992.

Técnicas de evaluación del potencial turistico. Madrid: Ministerio de Industria, Comercio y Turismo, 1993. 261p. (Serie Libros sobre Turismo, 2)

MACHADO, Rodrigo Vendramini; COSTA, Rogério Renê. Programa de educação continuada para os moradores da área urbana da estância climática de Cunha. Trabalho de Conclusão de Curso (Pós-graduação Lato Sensu) - Faculdade Senac de Turismo e Hotelaria de São Paulo, 2003. 171p.

MAGALHÃES, Guilherme Wendel de. (coord.) Pólos de ecoturismo; planejamento e gestão. São Paulo: TERRAGRAPH, 2001. 168p.

MAIA, Thereza Regina de Camargo; MAIA, Tom. O vale paulista do Rio Paraíba: história, geografia, fauna, flora, folclore, cidades: guia cultural. Rio de Janeiro: Documenta Histórica, 2005. 238p. 
MATHEUS, Zilda Maria Alves. Gestão e avaliação de programas - Estudo de Caso: Programa Nacional de Municipalização do Turismo - PNMT. Tese (Doutorado) - Escola de Comunicações e Artes, Universidade de São Paulo, 2003. 134p.

MODELO vitorioso de desenvolvimento sustentável. Roteiros da Estrada Real, Belo Hoeizonte, ano 2, n.4, maio 2005.

MOLINA, Sergio. Turismo; metodología para su planificación. México: Trillas, 1997. 101p. (Trillas Turismo)

MOLINA, Sergio, RODRíGUEZ, Sergio. Planejamento integral do turismo; um enfoque para a América Latina. Tradução por Carlos Valero. Bauru: EDUSC, 2001. 165p. (Coleção Turis)

MÜLLER, Nice Lecocq. O fato urbano na bacia do rio Paraíba; Estado de São Paulo. Rio de Janeiro: Fundação IBGE, 1969. 375p. (Biblioteca Geográfica Brasileira, 23, Série A)

O BRASILEIRO ADORA O BRASIL; O ESTRANGEIRO NEM TANTO. Revista Senac-SP, São Paulo, ano 6, n.20, p.4-10, jan./fev./mar. 2002.

OLIVARES, Diego López. La evaluación de los recursos territoriales turísticos de las comarcas del interior castellonense (Comunidade Valenciana). Disponível .

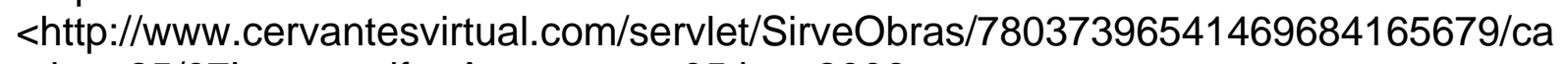
ttalogo25/07LLopez pdf

ORGANIZAÇÃO MUNDIAL DE TURISMO. Desenvolvimento de turismo sustentável; manual para organizadores locais. [S.I.] : [1994?] 217p.

PASIN, José Luiz. Uma bibliografia valeparaibana - história. Lorena: Centro Universitário Salesiano de São Paulo - Unidade de Lorena, 2005. 52p.

Vale do Paraíba - a Estrada Real; caminhos e roteiros. Aparecida: Santuário, 2004. 142p.

PEARCE, Douglas. Desarrollo turístico: su planificación y ubicación geográficas. Tradução por Lilia Soriano Bello. México: Trillas, 1991. 168p. Tradução de: Tourist development: topics in applied geography. (Trillas Turismo)

PEARCE, Douglas G.; BUTLER, Richard W.. (orgs.) Desenvolvimento em turismo; temas contemporâneos. Tradução por Edite Sciulli. São Paulo: Contexto, 2002. $325 p$. Tradução de: Contemporary issues in tourism development. (Coleção Turismo Contexto)

PELLEGRINI FILHO, Américo. Ecologia, cultura e turismo. Campinas: Papirus, 1993. 190p. (Coleção Turismo) 
PINZAN, Edson José. A potencialidade da atividade turística para 0 desenvolvimento regional. Dissertação (Mestrado) - Departamento de Geografia Humana, Faculdade de Filosofia, Letras e Ciências Humanas, Universidade de São Paulo, 2003. 147p.

PIRES, Paulo dos Santos. O despertar dos municípios para o turismo: potencialidades e limitações em análise. Turismo - Visão e Ação, Itajaí, vol.7, n.1, p. 175-192, jan./abr. 2005.

PRUDENTE, Henrique Alckmin. Turismo cultural - as culturas subalternas e o turismo emancipador em Cunha. Taubaté: Cabral, 2005. 159p.

REDE DE COOPERAÇÃO TÉCNICA PARA A ROTEIRIZAÇÃO. Relatório da oficina de planejamento da Região Sudeste. Paraty: 2005. 27p.

RUSCHMANN, Doris van de Meene. Planejamento turístico. In: ANSARAH, Marília Gomes dos Reis (org.). Turismo; como aprender, como ensinar. São Paulo: Ed. SENAC São Paulo, 2001. p. 65-86. (v.2)

Turismo e planejamento sustentável; a proteção do meio ambiente. Campinas: Papirus, 1997. 199p. (Coleção Turismo)

SANCHO, Amparo (dir.). Introducción al turismo. Madrid: Organización Mundial del Turismo, 1998. 392p.

SESSA, Alberto. Turismo e política de desenvolvimento. Tradução por Lourdes Fellini Sartor. Porto Alegre: UNIONTUR, 1983. 167p. Tradução de: Turismo e Politica de Sviluppo.

SILVA, Maria da Glória Lanci da. Cidades turísticas: identidades e cenários de lazer. São Paulo: Aleph, 2004. 192p. (Série Turismo)

SMITH, Stephen L. J.. Geografía recreativa; investigación de potenciales turísticos. Tradução por Víctor M. Estrada Villa. México: Trillas, 1992. 289p. Tradução de: Recreation Geography. (Trillas Turismo)

1989. 312p.

Tourism analysis; a handbook. Essex: Longman Scientific \& Technical,

SWARBROOKE, John. Turismo sustentável; conceitos e impacto ambiental. Tradução por Margarete Dias Pulido. São Paulo: Ed. Aleph, 2000. 140p. Tradução de: Sustainable Tourism Management. (Série Turismo, 1)

Turismo sustentável; gestão e marketing. Tradução por Esther Eva Horovitz. São Paulo: Ed. Aleph, 2000. 132p. Tradução de: Sustainable Tourism Management. (Série Turismo, 4)

TOLEDO, Francisco Sodero. Estrada Real: caminhos e descaminhos do ouro. Lorena: Centro Universitário Salesiano de Lorena, dez 2004. 89p. 
TRIGO, Luiz Gonzaga Godói. A importância da educação para o turismo. In: LAGE, Beatriz Helena Gelas; MILONE, Paulo César (org.). Turismo; teoria e prática. São Paulo: Atlas, 2000. P. 243-255.

WORLD TOURISM ORGANIZATION. Data collection and analysis for tourism management, marketing and planning; a manual for managers and analysts. Madrid: 1999. 150p.

National and regional tourism planning; methodologies and case studies. London: International Thomson Business Press, 1999. 249p. 


\section{APÊNDICE}

Apêndice 1 - Quadro: Evolução dos Núcleos Urbanos do Vale do Paraíba 


\begin{tabular}{|c|c|c|c|c|c|c|c|}
\hline \multirow{2}{*}{$\begin{array}{l}\text { Núcleos } \\
\text { Urbanos }\end{array}$} & \multirow[t]{2}{*}{ Origem } & \multicolumn{2}{|c|}{ Freguesia } & \multicolumn{2}{|r|}{ Vila } & \multicolumn{2}{|r|}{ Cidade } \\
\hline & & Data & Nome & Data & Nome & Data & Nome \\
\hline Alambari $^{73}$ & $\begin{array}{lr}\text { Distrito } & \text { de } \\
\text { Bananal, } 1891 \quad \text { e } \\
1944\end{array}$ & & & & & 1991 & Arapeí \\
\hline Aparecida & $\begin{array}{l}\text { Capela santuário, } \\
1743\end{array}$ & $\begin{array}{l}1842 \\
1880\end{array}$ & N. Sra. Aparecida & 1891 & & 1928 & Aparecida \\
\hline Areias & $\begin{array}{|lll|}\begin{array}{l}\text { Bairro } \\
\text { capela }\end{array} & \text { rural } & - \\
\end{array}$ & 1784 & $\begin{array}{ll}\text { Sant'Ana } & \text { de } \\
\text { Areias } & \\
\end{array}$ & 1816 & $\begin{array}{l}\text { São Miguel das } \\
\text { Areias }\end{array}$ & 1857 & Areias \\
\hline Arujá & Capela, 1781 & & & & & 1959 & Arujá \\
\hline Bairro Alto & Povoação & 1842 & $\begin{array}{l}\text { N. Sra. Aparecida } \\
\text { do Bairro Alto }\end{array}$ & 1939 & Bairro Alto & & \\
\hline Bananal & $\begin{array}{l}\text { Patrimônio } \\
\text { religioso }\end{array}$ & 1811 & $\begin{array}{l}\text { S. Bom Jesus do } \\
\text { Livramento do } \\
\text { Bananal }\end{array}$ & 1823 & & 1849 & Bananal \\
\hline Caçapava & $\begin{array}{l}\text { Patrimônio } \\
\text { religioso, } 1705\end{array}$ & 1813 & $\begin{array}{l}\text { N. Sra. da Ajuda } \\
\text { de Caçapava }\end{array}$ & 1855 & Caçapava & 1875 & Caçapava \\
\hline $\begin{array}{l}\text { Cachoeira } \\
\text { Paulista }\end{array}$ & $\begin{array}{l}\text { Patrimônio } \\
\text { religioso, } 1784\end{array}$ & 1876 & $\begin{array}{l}\text { Santo Antônio da } \\
\text { Cachoeira }\end{array}$ & 1880 & $\begin{array}{l}\text { Santo Antônio da } \\
\text { Bocaina }\end{array}$ & 1915 & Cachoeira \\
\hline $\begin{array}{l}\text { Campos de } \\
\text { Cunha }\end{array}$ & Povoado & 1872 & Campos Novos & 1938 & $\begin{array}{l}\text { Campos } \\
\text { Cunha }\end{array}$ & & \\
\hline Caninhas & Bairro rural, 1887 & & & & & 1993 & Canas \\
\hline Cruzeiro & Povoado & 1891 & $\begin{array}{lrl}\text { N. Sra. } & \text { da } \\
\text { Conceição } & \text { de } \\
\text { Cruzeiro } & \\
\end{array}$ & 1891 & & 1901 & Cruzeiro \\
\hline Cunha & Povoação, 1723 & $\begin{array}{l}1736 \\
1749\end{array}$ & $\begin{array}{lrl}\text { N. Sra. } & \text { da } \\
\text { Conceição } & \text { do } \\
\text { Facão } & \end{array}$ & 1785 & $\begin{array}{|ll|}\text { N. Sra. } & \text { Da } \\
\text { Conceição } & \text { de } \\
\text { Cunha } & \\
\end{array}$ & 1858 & \\
\hline
\end{tabular}

\footnotetext{
${ }^{73}$ Os dados sobre os municípios de Arapeí, Arujá, Canas e Potim foram obtidos em:

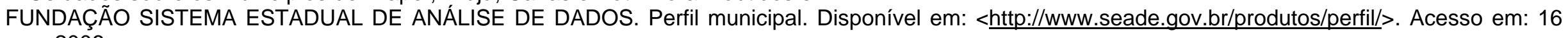
ago. 2006.
} 


\begin{tabular}{|c|c|c|c|c|c|c|c|}
\hline Embaú & \begin{tabular}{|l} 
Patrimônio \\
religioso, 1781
\end{tabular} & 1846 & $\begin{array}{|ll|}\text { N. Sra. } & \text { da } \\
\text { Conceição } & \text { do } \\
\text { Embaú } & \\
\end{array}$ & 1871 & $\begin{array}{l}\text { Conceição do } \\
\text { Cruzeiro }\end{array}$ & & \\
\hline Guararema & $\begin{array}{l}\text { Patrimônio } \\
\text { religioso }\end{array}$ & 1890 & Guararema & & & 1898 & Guararema \\
\hline Guaratinguetá & Povoado & & & 1651 & $\begin{array}{l}\text { Santo Antônio de } \\
\text { Guaratinguetá }\end{array}$ & 1844 & Guaratinguetá \\
\hline Igaratá & $\begin{array}{l}\text { Patrimônio, } \\
\text { 1840/1845 }\end{array}$ & 1864 & $\begin{array}{l}\text { N. Sra. do } \\
\text { Patrocínio }\end{array}$ & 1873 & $\begin{array}{l}\text { N. Sra. } \\
\text { Patrocínio }\end{array}$ & $\begin{array}{l}1906 \\
1934 \\
1953\end{array}$ & Igaratá \\
\hline Jacareí & Povoado, 1652 & & & 1653 & $\begin{array}{lrl}\text { N. Sra. } & \text { Da } \\
\text { Conceição } & \text { de } \\
\text { Jacareí } & \end{array}$ & 1849 & Jacareí \\
\hline Jambeiro & $\begin{array}{l}\text { Patrimônio } \\
\text { religioso, } 1871\end{array}$ & 1872 & Capivari & 1876 & $\begin{array}{l}\text { Capivari } \\
\text { Jambeiro }\end{array}$ & $1898^{74}$ & Jambeiro \\
\hline Lagoinha & Patrimônio, 1863 & 1866 & $\begin{array}{|ll|}\text { N. Sra. } & \text { da } \\
\text { Conceição } & \text { de } \\
\text { Lagoinha } & \\
\end{array}$ & 1880 & Lagoinha & 1953 & Lagoinha \\
\hline Lavrinhas & & & & 1917 & & 1934 & Lavrinhas \\
\hline Lorena & $\begin{array}{l}\text { Patrimônio } \\
\text { religioso, } 1705\end{array}$ & 1718 & \begin{tabular}{|ll} 
N. Sra. da \\
Piedade
\end{tabular} & 1788 & Lorena & 1856 & Lorena \\
\hline Monteiro Lobato & Bairro rural & 1857 & 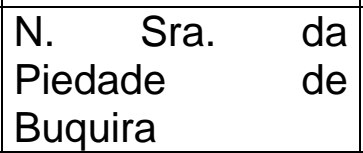 & 1880 & Buquira & 1953 & $\begin{array}{l}\text { Buquira } \\
\text { Monteiro Lobato }\end{array}$ \\
\hline $\begin{array}{l}\text { Natividade } \quad \text { da } \\
\text { Serra }\end{array}$ & Povoado, 1853 & 1858 & $\begin{array}{|lr|}\text { Divino } & \text { Espírito } \\
\text { Santo } & \text { da } \\
\text { Natividade } & \\
\end{array}$ & 1863 & Natividade & 1935 & Natividade da Serra \\
\hline $\begin{array}{l}\text { N. Sra. da } \\
\text { Escada }\end{array}$ & Aldeamento & $\begin{array}{l}1846 \\
1872\end{array}$ & $\begin{array}{l}\text { N. Sra. da } \\
\text { Escada }\end{array}$ & & & & \\
\hline
\end{tabular}

\footnotetext{
${ }^{74}$ Fonte:

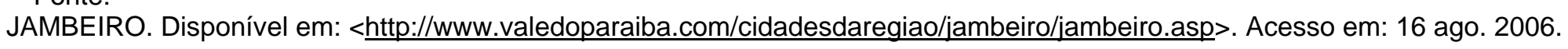




\begin{tabular}{|c|c|c|c|c|c|c|c|}
\hline Paraibuna & Povoado, 1773 & 1812 & \begin{tabular}{|l|} 
Santo Antônio de \\
Paraibuna
\end{tabular} & 1863 & \begin{tabular}{|l|} 
Santo Antônio de \\
Paraibuna
\end{tabular} & 1857 & Paraibuna \\
\hline Pindamonhangaba & $\begin{array}{l}\text { Patrimônio } \\
\text { religioso }\end{array}$ & & \begin{tabular}{|lr} 
N. Sra. do & Bom \\
Sucesso & de \\
Pindamonhangaba \\
\end{tabular} & 1705 & & 1849 & Pindamonhangaba \\
\hline Pinheiro & Povoado & 1845 & \begin{tabular}{|ll} 
São Francisco de \\
Paula & de \\
Pinheiros &
\end{tabular} & 1881 & \begin{tabular}{|ll} 
São Francisco de \\
Paula & de \\
Pinheiros &
\end{tabular} & & \\
\hline Piquete & Povoado, 1842 & 1875 & \begin{tabular}{|l|} 
São Miguel de \\
Piquete
\end{tabular} & 1891 & \begin{tabular}{|l|} 
Vila Vieira do \\
Piquete
\end{tabular} & 1915 & Piquete \\
\hline Potim & Capela, 1722 & & & & & 1991 & Potim \\
\hline Queluz & $\begin{array}{l}\text { Aldeamento, } \\
1800\end{array}$ & 1803 & $\begin{array}{l}\text { São João Batista } \\
\text { do Queluz }\end{array}$ & 1842 & & 1876 & Queluz \\
\hline $\begin{array}{ll}\text { Redenção } & \text { da } \\
\text { Serra } & \end{array}$ & Bairro rural & 1860 & \begin{tabular}{|l|} 
Santa Cruz do \\
Paiolinho
\end{tabular} & 1877 & Redenção & 1935 & Redenção da Serra \\
\hline Roseira & & & & 1910 & Roseira & 1959 & Roseira \\
\hline Santa Branca & $\begin{array}{l}\text { Patrimônio } \\
\text { religioso, } 1833\end{array}$ & 1841 & Santa Branca & 1856 & Santa Branca & & Santa Branca \\
\hline Santa Isabel & $\begin{array}{l}\text { Patrimônio } \\
\text { religioso }\end{array}$ & 1812 & Santa Isabel & 1832 & Santa Isabel & 1893 & Santa Isabel \\
\hline $\begin{array}{ll}\text { São } & \text { Francisco } \\
\text { Xavier } & \\
\end{array}$ & Bairro rural & 1892 & $\begin{array}{|ll|}\text { São } & \text { Francisco } \\
\text { Xavier } & \\
\end{array}$ & & & & \\
\hline $\begin{array}{l}\text { São José do } \\
\text { Barreiro }\end{array}$ & $\begin{array}{l}\text { Patrimônio } \\
\text { religioso, } 1803\end{array}$ & 1842 & $\begin{array}{l}\text { São José do } \\
\text { Barreiro }\end{array}$ & 1859 & $\begin{array}{l}\text { São José do } \\
\text { Barreiro }\end{array}$ & 1885 & São José do Barreiro \\
\hline $\begin{array}{l}\text { São José dos } \\
\text { Campos }\end{array}$ & $\begin{array}{l}\text { Aldeamento, } \\
1643\end{array}$ & 1768 & \begin{tabular}{|l|} 
São José do \\
Paraíba
\end{tabular} & 1767 & $\begin{array}{l}\text { Vila Nova de São } \\
\text { José do Paraíba }\end{array}$ & 1864 & $\begin{array}{l}\text { São José do Paraíba } \\
\text { São José dos Campos }\end{array}$ \\
\hline $\begin{array}{l}\text { São Luís do } \\
\text { Paraitinga }\end{array}$ & Povoado, 1769 & & & 1773 & \begin{tabular}{|l|} 
São Luís do \\
Paraitinga
\end{tabular} & 1857 & São Luís do Paraitinga \\
\hline Silveiras & Bairro rural & 1830 & \begin{tabular}{|lrl} 
N. Sra. & da \\
Conceição & de \\
Silveiras &
\end{tabular} & 1842 & Silveiras & 1864 & Silveiras \\
\hline Taubaté & Povoado, & & & 1645 & Francisco & 1842 & Taubaté \\
\hline
\end{tabular}




\begin{tabular}{|l|l|l|l|l|l|l|}
\hline & $1636 / 39$ & & $\begin{array}{l}\text { das Chagas de } \\
\text { Taubaté }\end{array}$ & \\
\hline Tremembé & $\begin{array}{l}\text { Patrimônio } \\
\text { religioso, } 1672\end{array}$ & $\begin{array}{l}1866 \\
1891\end{array}$ & $\begin{array}{l}\text { S. Bom Jesus do } \\
\text { Tremembé }\end{array}$ & & & 1896 \\
\hline
\end{tabular}

Quadro 24 - Evolução dos Núcleos Urbanos do Vale do Paraíba Fonte: MÜLLER, 1969, p.39-40. 
This document was created with Win2PDF available at http://www.win2pdf.com.

The unregistered version of Win2PDF is for evaluation or non-commercial use only.

This page will not be added after purchasing Win2PDF. 